\title{
Early Childhood Policies and Systems in Eight Countries
}

Findings from IEA's Early Childhood Education Study

Tony Bertram and Chris Pascal

with

Anne Cummins, Sean Delaney,

Chris Ludlow, Helen Lyndon, Juliane Hencke, Marta Kostek,

Steffen Knoll, Agnes Stancel-Piatak

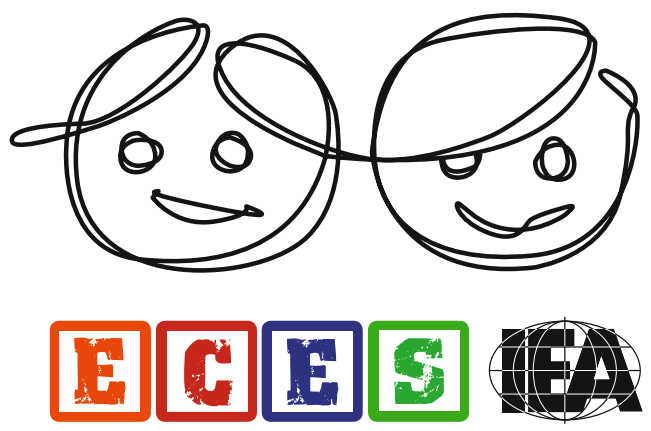

IEA EARLY CHILDHOOD EDUCATION STUDY 
Early Childhood Policies and Systems in Eight Countries 

Tony Bertram $•$ Chris Pascal

\section{Early Childhood Policies and Systems in Eight Countries}

Findings from IEA's

Early Childhood Education Study

With Anne Cummins, Sean Delaney, Chris Ludlow, Helen Lyndon, Juliane Hencke, Marta Kostek, Steffen Knoll and Agnes Stancel-Piatak 
Tony Bertram

CREC

Centre for Research in Early Childhood

United Kingdom
Chris Pascal

CREC

Centre for Research in Early Childhood

United Kingdom

For more information about ECES contact:

ECES International Study Center

IEA Data Processing and Research Center

Mexikoring 37

22297 Hamburg

GERMANY

tel: $\quad+494048500701$

fax: $\quad+494048500501$

e-mail: eces@iea-dpc.de

http://eces.iea.nl

\section{Disclaimer}

As the Italian Ministry of Education, Universities and Research is not responsible in general for ECED in Italy, any data regarding this sector is provided on the condition that the Ministry not be held accountable in terms of the reliability and validity of this data. INVALSI, aggregating existing data and sources, responded to the IEA questionnaire to the best of its ability, considering system changes currently under development for the entire ISCED 0 level. The reported situation for Italy might thus be subject to change or might be lacking information in this transitional phase to the new system reform. An example is the new National (self-)Evaluation of Preschools currently being implemented.

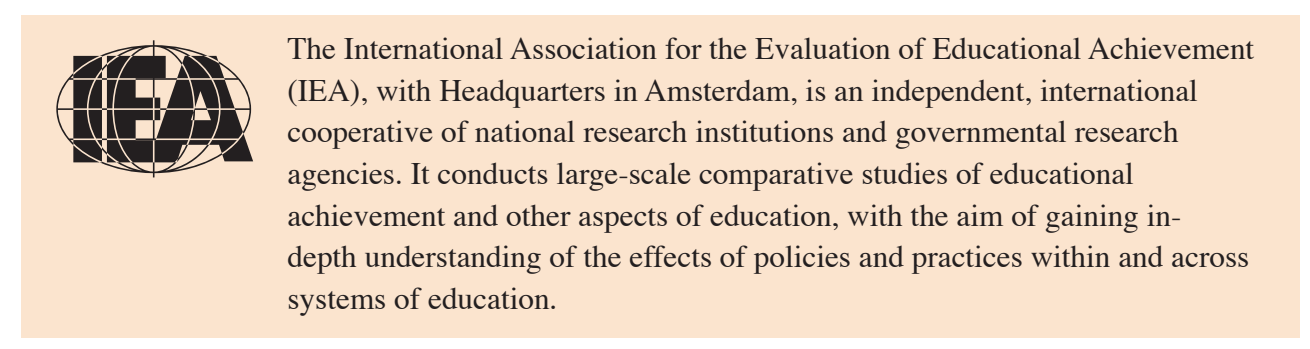

Design and production by Becky Bliss Design and Production, Wellington, New Zealand
ISBN 978-3-319-39846-4
ISBN 978-3-319-39847-1 (eBook)
DOI 10.1007/978-3-319-39847-1

Library of Congress Control Number: 2016948207

(C) International Association for the Evaluation of Educational Achievement (IEA) 2016. This book is published open access.

Open Access This book is distributed under the terms of the Creative Commons Attribution-NonCommercial 4.0 International License (http://creativecommons.org/licenses/by-nc/4.0/), which permits any noncommercial use, duplication, adaptation, distribution and reproduction in any medium or format, as long as you give appropriate credit to the original author(s) and the source, provide a link to the Creative Commons license and indicate if changes were made.

The images or other third party material in this book are included in the works Creative Commons license, unless indicated otherwise in the credit line; if such material is not included in the works Creative Commons license and the respective action is not permitted by statutory regulation, users will need to obtain permission from the license holder to duplicate, adapt or reproduce the material.

The use of general descriptive names, registered names, trademarks, service marks, etc. in this publication does not imply, even in the absence of a specific statement, that such names are exempt from the relevant protective laws and regulations and therefore free for general use.

The publisher, the authors and the editors are safe to assume that the advice and information in this book are believed to be true and accurate at the date of publication. Neither the publisher nor the authors or the editors give a warranty, express or implied, with respect to the material contained herein or for any errors or omissions that may have been made.

Printed on acid-free paper

This Springer imprint is published by Springer Nature

The registered company is Springer International Publishing AG Switzerland 


\section{Foreword}

Educational policymakers around the world are increasingly aware that early childhood education (ECE) can have a strongly positive impact on a child's further development. Several countries have implemented reforms of their early childhood systems, generally focusing on a stronger emphasis on education and preparation for school. However, ECE systems remain diverse, with many countries still exploring the best options for their national educational system. This study gives an overview of the current status of ECE in eight different countries. This initial analysis enables in-depth comparison of policy provision within the different countries, with the goal of learning from the range of approaches to implementation adopted.

The report reveals that there are considerable differences in policies, delivery models, providers, access to, and participation in ECE, and in national expectations for child outcomes. Even the general aims of ECE differ among countries. However, almost all countries are investing extensively, and thus to investigate the success of such investments is natural. Helping policymakers and researchers in their efforts to better understand differing educational systems, and thus assisting with educational reform and improvement efforts, is central to the IEA's mission.

This study is intended to establish further avenues for investigation into the differences in ECE policies, practices and outcomes among different countries. The IEA envisions that outcome measures will be the subject of future research to progress knowledge in this area. Such assessments need to be carefully tailored to incorporate national goals for child outcomes, which may also be diverse.

An endeavor such as this could not be successful without the dedication of a large number of individuals, institutions, and organizations around the world. The IEA thanks the many experts, institutions, and organizations who made this project possible for their enthusiastic engagement and commitment to this project.

The IEA is particularly indebted to the outstanding teams of experts at the Centre for Research in Early Childhood (CREC), the National Foundation for Educational Research (NFER), the IEA Headquarters and the IEA Data Processing and Research Center (IEA DPC).

On behalf of IEA, I thank the principal authors of the report, Chris Pascal and Tony Bertram from CREC, who were largely responsible for the policy phase of the IEA's Early Childhood Education Study. My thanks go also to Caroline Sharp and Bethan Burge from NFER for their immense contribution to this study. Finally, my sincere gratitude goes to the study coordination at the IEA DPC, led by the study director Juliane Hencke and the study coordinator Marta Kostek, whose contribution to the content, as well as the overall management of the study, cannot be overstated. 
I also thank the Project Advisory Committee (PAC): Cristina Stringher, Elena Yudina, Sylvia Eyzaguirre, and Sun Jin, and additionally Agnes Stancel-Piatak, Steffen Knoll, Sabine Meinck, Hannah Köhler, Paulína Koršnáková and Roel Burgers (all from the IEA). The IEA Technical Executive Group (TEG) provided valuable feedback to the study design and the report format, and the IEA Publication Editorial Committee (PEC), under the lead of Seamus Hegarty, ensured the high quality of the final publication. Gillian Wilson edited the report. Finally, my sincere thanks go to the national centers that provided the study finance, as well as the data for the report.

My thanks also go to the country representatives: Josef Basl, Irena Borkovcova, Gabriela Cares Osorio, Kristin Flanagan, Dana Kelly, Grethe Kragh-Muller, Tiina Peterson, Charlotte Ringmose, Piotr Rycielski, Kamil Sijko, Cristina Stringher, Marika Veisson, and Elena Yudina. The country representatives provided invaluable input throughout the study, reviewing and completing the Policy Questionnaire, an effort that required substantial research to gather all the information required, as well as commenting on the content of this Report. I am grateful for their unstinting commitment to this project.

\section{Dirk Hastedt}

EXECUTIVE DIRECTOR, IEA HAMBURG, FEBRUARY 2016 


\section{Contents}

Chapter 1: Summary of Key Findings $\quad 1$

About the Study $\quad 1$

Public Policy 1

Delivery Models and Providers 2

Participation and Enrollment $\quad 4$

Supporting Quality in ECE

Expectations for Child Outcomes 6

Chapter 2: Introduction $\quad 9$

The Policy Questionnaire 9

Definition of Early Childhood Education (ECE) Programs 10

Participating Countries 11

Methodology of the Policy Questionnaire $\quad 11$

Structure of the Policy Report $\quad 12$

Chapter 3: Overview of the Structures of the Early Childhood Education 13 and Care Systems in the Participating Countries

Structure of ECE Systems $\quad 13$

Parental Leave $\quad 17$

Final Remarks $\quad 19$

$\begin{array}{ll}\text { Chapter 4: Public Policy } & 21\end{array}$

Policy Aims $\quad 21$

Governance and System Management $\quad 24$

Legislative Status and Statutory Entitlements for Children and Parents $\quad 30$

$\begin{array}{ll}\text { Policy Changes } & 37\end{array}$

Chapter 5: Delivery Models and Providers 43

Setting Types and Characteristics 43

Target Populations $\quad 56$

Setting Enrollment Rates $\quad 57$

Setting Funding Strategies $\quad 58$

System Transitions $\quad 62$

Chapter 6: Participation and Enrollment $\quad 65$

Levels of Participation in ECE Programs for Children from Subgroups of the 66

Overall Population

Children from Low-Income Families $\quad 66$

Children with Special Needs or Disability $\quad 68$

Children from a Minority Ethnic Group $\quad 68$

Children whose Home Language is Different than the National Language 68

Prioritizing or Targeting Strategies for ECE Enrollment 69

Diversity and Cultural Responsiveness of Settings 71

Coverage and Availability of ECE Provision 73

Costs to Parents for Participation in ECE 77

$\begin{array}{ll}\text { Targeted Early Intervention Programs } & 78\end{array}$ 
Chapter 7: Supporting Quality in ECE $\quad 81$

Regulatory Environment $\quad 81$

Staff Qualifications, Training and Remuneration 86

Group Size and Ratios $\quad 105$

$\begin{array}{ll}\text { Health and Safety Measures } & 108\end{array}$

ECE Curriculum Guidance and Pedagogic Approaches 109

Parental Participation In Learning $\quad 115$

Accreditation, Inspection, Reporting and Accountability $\quad 117$

Chapter 8: Expectations for Child Outcomes, Assessment and Reporting 129

$\begin{array}{ll}\text { Expectations for Child Outcomes } & 129\end{array}$

Assessment Methods $\quad 131$

Reporting of Outcomes Data 134

$\begin{array}{ll}\text { Use of Child Outcomes Data } & 135\end{array}$

Chapter 9: Individual Country Profiles 139

Country Profile: Chile $\quad 140$

Country Profile: Czech Republic 143

Country Profile: Denmark 146

Country Profile: Estonia $\quad 149$

Country Profile: Italy $\quad 152$

Country Profile: Poland 156

Country Profile: Russian Federation $\quad 159$

Country Profile: United States 162

Chapter 10: Final Reflections: Emerging Policy Issues 167

$\begin{array}{ll}\text { Public Policy } & 168\end{array}$

Delivery Models and Providers $\quad 172$

Participation and Enrollment $\quad 172$

Supporting Quality in ECE $\quad 173$

Expectations for Child Outcomes $\quad 176$

$\begin{array}{ll}\text { Concluding Comments } & 177\end{array}$

$\begin{array}{ll}\text { References } & 179\end{array}$

Appendices

Appendix A: Glossary 183

Appendix B: Organizations and Individuals Involved in ECES 191 


\section{List of Figures}

Figure 1: The study countries 11

Figure 2: Overview of ISCED Level 0 in the eight participating countries $\quad 15$

Figure 3: Length of postnatal maternity, paternity and parental leave (in weeks) 18

Figure 4: Age of start of ISCED Level 1 31

\section{List of Tables}

Table 1: Percentage enrollment in formal care and preschool by age phase in 17 study countries

Table 2: $\quad$ Stated policy aims for children aged 0-3 years (ECED) and children 23 aged 3 to the start of primary school (PPE)

Table 3: Level of government responsible for setting ECE policy for children aged $0-3$ years (ECED) and children aged 3 to the start of primary schooling (PPE)

Table 4: $\quad$ Bodies or ministries responsible for children aged 0-3 years (ECED) 28 and children aged 3 to the start of primary schooling (PPE)

Table 5: $\quad$ Statutory entitlements to services for children aged 0-3 years (ECED) 32 and children aged 3 to the start of primary school (PPE)

Table 6: Statutory entitlements to parental leave and pay for parents of children aged 0-3 years (ECED) and children aged 3 to the start of primary school (PPE)

Table 7: $\quad$ Key policy changes for services for children aged 0-3 years (ECED) 38 and children aged 3 to the start of primary school (PPE)

Table 8a: Main setting types and characteristics of services for children aged $0-3$ years (ECED) and children aged 3 to the start of primary school (PPE) in Chile

Table 8b: Main setting types and characteristics of services for children aged $0-3$ years (ECED) and children aged 3 to the start of primary school (PPE) in the Czech Republic

Table 8c: Main setting types and characteristics of services for children aged $0-3$ years (ECED) and children aged 3 to the start of primary school (PPE) in Denmark

Table 8d: Main setting types and characteristics of services for children aged $0-3$ years (ECED) and children aged 3 to the start of primary school (PPE) in Estonia

Table 8e: Main setting types and characteristics of services for children aged 0-3 years (ECED) and children aged 3 to the start of primary school (PPE) in Italy

Table 8f: Main setting types and characteristics of services for children aged $0-3$ years (ECED) and children aged 3 to the start of primary school (PPE) in Poland

Table 8g: Main setting types and characteristics of services for children aged 0-3 years (ECED) and children aged 3 to the start of primary school (PPE) in the Russian Federation

Table 8h: Main setting types and characteristics of services for children aged $0-3$ years (ECED) and children aged 3 to the start of primary school (PPE) in the United States 
Table 9: Enrollment rates for children aged from 0-3 years (ECED) and from

3 years to the start of primary schooling (PPE) at different ages

Table 10: Supply-side funding from central funds for children aged from 0-3 (ECED) and children aged from 3 to the start of primary schooling (PPE)

Table 11: Demand-side funding for children aged from 0-3 (ECED) and children aged from 3 to the start of primary schooling (PPE)

Table 12: Child characteristics and enrollment levels of children aged from $0-3$ years (ECED) and children aged from 3 years to the start of primary schooling (PPE)

Table 13: Existence and focus of prioritizing regulations for children aged 0-3 years (ECED) and children aged from 3 to the start of primary schooling (PPE)

Table 14: Diversity and cultural responsiveness strategies for children aged 0-3 years (ECED) and children aged from 3 years to the start of primary schooling (PPE)

Table 15: Existence of universal coverage of services for children aged $0-3$ years (ECED) and children aged 3 to the start of primary school (PPE) and areas of limited service availability

Table 16: Strategies to increase coverage of ECE provision for children aged 0-3 76 years (ECED) and children aged 3 to the start of primary school (PPE)

Table 17: Existence of targeted early intervention programs at target groups for 79 children aged $0-3$ years (ECED) and children aged 3 to the start of primary schooling (PPE)

Table 18a: Regulatory responsibilities at national level for children aged 0-3 years 83 (ECED) and children aged 3 to the start of primary school (PPE)

Table 18b: Regulatory responsibilities at subnational level for children aged $0-3$ years (ECED) and children aged 3 to the start of primary school (PPE)

Table 19a: Main staff and leader categories, minimum qualification level, continuing professional development (CPD) opportunities, and average annual remuneration level in US\$ of staff who work in services for children aged 0-3 years (ECED) and children aged 3 to the start of primary school (PPE) in Chile

Table 19b: Main staff and leader categories, minimum qualification level, continuing professional development (CPD) opportunities and average annual remuneration level in US\$ of staff who work in services for children aged 3 to the start of primary school (PPE) in Czech Republic

Table 19c: Main staff and leader categories, minimum qualification level, continuing professional Development (CPD) opportunities and average annual remuneration level in US\$ of staff who work in services for children aged 0-3 years (ECED) and children aged 3 to the start of primary school (PPE) in Denmark

Table 19d: Main staff and leader categories, minimum qualification level, continuing professional development (CPD) opportunities, and average annual remuneration level in US\$ of staff who work in services for children aged 0-3 years (ECED) and children aged 3 to the start of primary school (PPE) in Estonia 
Table 19e: Main staff and leader categories, minimum qualification level, continuing professional development (CPD) opportunities, and average annual remuneration level in US\$ of staff who work in services for children aged 0-3 years (ECED) and children aged 3 to the start of primary school (PPE) in Italy

Table 19f: Main staff and leader categories, minimum qualification level, ontinuing professional development (CPD) opportunities and average annual remuneration level in US\$ of staff who work in services for children aged 0-3 years (ECED) and children aged 3 to the start of primary school (PPE) in Poland

Table 19g: Main staff and leader categories, minimum qualification level, continuing professional development (CPD) opportunities and average annual remuneration level in US\$ of staff who work in services for children aged 0-3 years (ECED) and children aged 3 to the start of primary school (PPE) in the Russian Federation

Table 19h: Main staff and leader categories, minimum qualification level, continuing professional development (CPD) opportunities and average annual remuneration level in US\$ of staff who work in services for children aged 0-3 years (ECED) and children aged 3 to the start of primary school (PPE) in the United States

Table 19i: Distribution of educational attainment for staff who work in settings that serve children birth to three years in the United States

Table 19j: Distribution of educational attainment for staff who work in settings that serve children three years to not-yet-in-kindergarten in the United States

Table 19k: Qualifications of staff who work as teachers in private and public primary schools in the United States

Table 20: Regulated group size for children aged 0-3 years (ECED) and children aged 3 to the start of primary school (PPE)

Table 21: Regulated staff:child ratios for children aged 0-3 years (ECED) and children aged 3 to the start of primary school (PPE)

Table 22: Existence and scope of health and safety regulations for children aged $0-3$ years (ECED) and children aged 3 to the start of primary school (PPE)

Table 23: Existence and content of curriculum guidance for children aged $0-3$ years (ECED) and children aged 3 to the start of primary school (PPE)

Table 24: Areas of learning included in curriculum guidance for children aged $0-3$ years (ECED) and children aged 3 to the start of primary school (PPE)

Table 25: Pedagogic approaches promoted in national guidance for children aged $0-3$ years (ECED) and children aged 3 to the start of primary school (PPE)

Table 26: Existence of guidance on parental partnership and level of parent participation in settings for children aged $0-3$ years (ECED) and children aged 3 to the start of primary school (PPE) 
Table 27: Existence of a responsible body at national or subnational level for the accreditation of settings for children aged $0-3$ years (ECED) and children aged 3 to the start of primary school (PPE)

Table 28: Existence of a responsible body at national or subnational level for the inspection of settings for children aged $0-3$ years (ECED) and children aged 3 to the start of primary school (PPE)

Table 29: Aspects of quality assurance processes covered by accreditation for children aged $0-3$ years (ECED) and children aged 3 to the start of primary school (PPE)

Table 30: Aspects of quality assurance processes covered by inspection for children aged $0-3$ years (ECED) and children aged 3 to the start of primary school (PPE)

Table 31: Reporting of results of accreditation of settings for children aged 0 to 3 years (ECED) and children aged 3 to the start of primary school (PPE)

Table 32: Reporting of results of inspection of settings for children aged $0-3$ years (ECED) and children aged 3 to the start of primary school (PPE)

Table 33: Use of accreditation results of settings to inform the development of policy and practice in settings for children aged $0-3$ years (ECED) and children aged 3 to the start of primary school (PPE)

Table 34: Use of inspection results of settings to inform the development of policy and practice in settings for children aged $0-3$ years (ECED) and children aged 3 to the start of primary school (PPE)

Table 35: Expectations for child outcomes in different areas of learning and development for children aged 0-3 years (ECED) and children aged 3 to the start of primary school (PPE)

Table 36: Existence of national or subnational child assessments in different areas of learning and development for children aged $0-3$ years (ECED) and children aged 3 to the start of primary school (PPE)

Table 37: Assessment methods used for children aged 0-3 years (ECED) and children aged 3 to the start of primary school (PPE)

Table 38: Recipients of reporting of child outcomes data for children aged $0-3$ years (ECED) and children aged 3 to the start of primary school (PPE)

Table 39: Use of child outcomes data for children aged 0-3 years (ECED) and children aged 3 to the start of primary school (PPE) 


\section{CHAPTER 1:}

\section{Summary of Key Findings}

\section{About the Study}

The IEA International Early Childhood Education Study (ECES) is a comparative research program of the International Association for the Evaluation of Educational Achievement (IEA). The purpose of the study is to explore, describe and critically analyze early childhood education (ECE) provision and its role in preparing children for the learning and social demands of school and wider society.

In the context of IEA's ECES, ECE has been defined as formal early education and care provision for young children from birth up to the age of primary education. This period is defined under the UNESCO International Standard Classification of Education (ISCED) system as ISCED Level 0 (UNESCO [United Nations Educational, Scientific and Cultural Organization] Institute for Statistics, 2012). ISCED Level 0 can be further divided into early childhood educational development programs (ECED) (ISCED Level 0.1) and programs in pre-primary education (PPE) (ISCED Level 0.2) (see Appendix A for more detail).

The data analyzed in this report were collected using a policy questionnaire addressed to and completed by the National Research Coordinator(s) (NRC) of eight participating countries. The participating countries were: Chile, the Czech Republic, Denmark, Estonia, Italy, Poland, the Russian Federation and the United States. It should be noted that the eight participating countries opted into the study and so cannot be viewed as a representative or purposefully selected sample of country types. Nevertheless, they do provide interesting illustrations of ECE policy in action in a range of diverse contexts.

The questionnaire collected basic information about the wider policy context for ECE from birth to the age of primary schooling in each participating country. In particular, it aimed to provide an overview of policy strategies, as well as the systemic and structural results of ECE policy at national and, where necessary, subnational levels.

The analysis of the survey data enabled transnational comparisons in policy and systems, and documented key policy changes underway and planned. These data revealed a set of key findings in each of the five policy areas as covered in the questionnaire and this report: public policy; delivery models and providers; participation and enrollment; supporting quality in ECE; and expectations for child outcomes. These key findings are highlighted throughout the report with their supporting evidence, but are all summarized below for ease of access.

\section{Public Policy}

1. All eight study countries have a wide range of policy aims for ECE, including aims to support a child's development and learning agenda, aims to support parental employment and training, aims that address wider social and civic issues, and aims that support early intervention for language needs or special needs. This suggests that ECE policy is being used to meet a spectrum of social, economic, educational, and political demands in all eight study countries.

2. Among the study countries, a mix of national and regional or local level governance (national and subnational) has been implemented to manage ECE services dedicated both to children under three years (early childhood education and 
development: ECED) and children three years and over (pre-primary education: PPE). The influence of national level governance increases as provision moves towards the pre-primary year and transition to the schooling system. This suggests that for younger children there is increased potential for local or regional variation in the delivery of services.

3. There is a complex system of governance and system management for ECE in most of the study countries. In seven of the eight study countries, responsibility for delivering and managing ECE services at a national, local or regional level is distributed among a range of national bodies or ministries at each of these levels and between different phases in ISCED Level 0 (ECED and PPE services, including kindergarten). Only in Estonia is there a unitary system with one national body responsible for services throughout the entire ISCED Level 0 . This complexity in system governance and management is especially evident in the development and delivery of policy for children under three years (ECED).

4. Four of the eight study countries have statutory entitlements for children to have access to some level of ECED service, ranging from sessional, to half day, to fulltime programs, with relatively generous levels of entitlement in Denmark, Estonia and the Russian Federation. Six of the eight study countries have statutory or universal, non-mandatory entitlement for children to full-time PPE services in the year before entry to primary schooling, again with relatively generous levels of entitlement in Denmark, Estonia and the Russian Federation. This would seem to be in line with the trend internationally towards a establishing a universal and statutory ECE system, particularly at PPE level (European Commission/EACEA [The Education, Audiovisual and Culture Executive Agency]/Eurydice [Education Network in Europe]/Eurostat, 2014; OECD, 2012b).

5. In most of the study countries, national policy indicates an acceptance that parents, particularly mothers, need to be supported in balancing their work and family commitments; the majority of study countries incorporate an entitlement to some level of parental leave, usually maternity leave. However, the complexity of eligibility requirements, limitations on accessing some entitlements, the variable level of salary compensation and complex timing of the leave entitlements within the study countries create challenges for parents and employers to navigate and for policymakers to address if parental leave is to form a coherent and equitable part of an integrated ECE system.

6. All study countries have recently undergone, or have imminent plans for substantial changes in their ECE policy, at both ECED and PPE levels. In particular, increases in public expenditure and enhanced statutory entitlements to ECE services are the most common recent or planned changes. The evidence illustrates the dynamic nature of ECE policy and reflects the growing visibility and importance attached to the development of the ECE systems within all the study countries.

\section{Delivery Models and Providers}

7. In all study countries, there are various setting types or forms of provision delivering ECE services to children under three years old (ECED) and from three years up to primary school age (PPE). These include home-based and center-based services, and may be called crèches, kindergartens, nursery schools, nursery or kindergarten classes in primary schools, kids clubs, preschools, day-care centers and integrated centers. Some countries have a greater variety of setting types than others, and the 
number of setting types also tends to reduce with the age of the child. The variety in types of provision within the study countries exemplifies the current complexity and diversity in the delivery of ECE services during ISCED Level 0.

8. Settings in the study countries are mostly focused on a particular age group of children, usually birth to three years of age (ECED) or children aged three to primary school age (PPE); however, Denmark and Estonia have fully integrated settings that cater for children from birth to primary school age.

9. Funding for ECE settings is complex. In Denmark and Estonia, all ECED and PPE settings are fully publicly funded, but in Chile, the Czech Republic, Italy, Poland, the Russian Federation and the United States, settings can be fully publicly funded, fully privately funded, or receive a mixture of public and private funding.

10. All of the study countries have ECE settings that offer a range of daily schedule options, from shorter sessions to extended day services (over 10 hours), with the Russian Federation also offering 24-hour services in one type of setting. Parents may have to use more than one setting to meet their needs of 10 or more hours. In the United States, for example, a child may attend a preschool at a primary center in the morning, a different program in the afternoon, and home-based childcare in the late afternoon to evening.

11. There are differing approaches to targeting certain populations to enhance their participation in ECE services, with some countries avoiding a targeting approach, and adopting a universal and integrated approach (Czech Republic, Italy and Poland) and others embracing targeting as a useful strategy to increase the integration and inclusion of certain groups, particularly children from lowincome families and children with special needs or disability (Chile, Denmark, Estonia, the Russian Federation and the United States).

12. Enrollment levels to ECE services appear to increase in line with the age of the child, with high levels of enrollment (above 86\%) in all the study countries (where data available) in the final year of ISCED Level 0 , and some countries approaching $100 \%$ enrollment.

13. Supply-side and demand-side funding are both used extensively in the study countries as key elements in the financing of ECE settings at both ECED and PPE levels. Supply-side funding is used in a variety of ways, including subsidizing funded places, subsidizing staff salaries, and providing capital and resource grants to settings. Methods of demand-side funding include: providing tax credits or relief, offering vouchers to parents, reduced fees, and paying family allowances. In those countries where there is largely publicly-funded ECE provision (Denmark, Estonia and Italy) supply-side funding predominates.

14. In the study countries there is an awareness of the importance of offering support in transition for parents, children and practitioners at key points in the ECE system and through to ISCED Level 1, and encouragement at national or subnational level levels for the incorporation of transition strategies within ECE practice in the majority of the study countries, supported by national guidelines in Chile, the Czech Republic, Denmark, Estonia, the Russian Federation and the United States. 


\section{Participation and Enrollment}

15. There is significant variation between the study countries as to the number of children in the population who are from low-income families, have special needs or disability, are from minority ethnic groups, and whose home language is different from the national language. In some countries, these subgroups can form a very sizable element of the population; this has implications for policy choices. Even given this variation, when comparing the study countries that submitted evidence, there are differences in the level of enrollment of children from these subgroups, with some countries achieving much higher levels of enrollment proportionally than others. In particular, the study countries offering publicly-funded universal ECE have a significantly higher level of participation of these subgroups than countries where there is targeted funded entitlement.

16. Prioritizing regulations or targeting strategies to allocate ECE places preferentially are commonly used in the study countries at national and/or local level. A range of social, developmental and economic criteria are used by the study countries to focus the targeting strategies, with the most common prioritizing regulations aimed at enhancing ECE participation for children from low-income families and children with special educational needs or disability.

17. The promotion of culturally and linguistically responsive practices in ECE settings to increase the enrollment and participation of children from diverse social and cultural backgrounds is evident in all the study countries, and usually supported by legislation.

18. There is more universal coverage of ECE places at PPE level than for children at ECED level. Shortage of ECE places is greater for children under the age of three years, and this shortage can also be more acute for children living in rural areas, from low-income families, or who have special needs or disability.

19. In the seven study countries where there is a national commitment to achieve universal coverage of ECE services, strategies have been adopted to increase the geographic coverage of services and to extend their opening hours in order to enhance the participation of all children.

20. Ascertaining the costs of ECE services to parents can be difficult, as charging policy and practice are not generally nationally documented. However, the data from the participating countries suggest that when free universal publicly-funded ECE services are unavailable, there is evidence that these costs can constitute a significant proportion of household income. This also implies that the costs to parents may be a significant factor when looking at levels of child enrollment in ECE services.

21. Targeted intervention programs as part of ECE services are used extensively in the majority of study countries as a mechanism to provide additional and early support for children from low-income families, children from minority ethnic groups, children with special needs or disability, and children whose home language is different from the national language. The intervention may take a variety of forms, including input from specialist professionals, providing additional resources, running support groups, providing specialist advice, and supplying internet-based study material to support professional practice. 


\section{Supporting Quality in ECE}

22. All study countries regulate their ECE services, with regulatory responsibilities being distributed between national and subnational bodies, indicating a desire to ensure all ECE services meet minimal standards. Some countries appear to regulate more than others, and some aspects of service delivery are more regulated than others, with the most frequently reported regulated aspects across countries overall being health and safety, and child protection. The system for monitoring regulatory compliance may also be very complex, with a wide range of national and subnational bodies with compliance responsibility for different aspects of regulation in many of the study countries.

23. A comparison of the information presented for the study countries illustrates the diversity of staffing for ECE services, which varies by age phase, type of setting, setting provider (public or private), location and professional role of staff. In services for under-threes (ECED), a wide range of child care, educator and health focused staff are found in the study countries, but there are more "education" focused staff than "care" or "health" focused staff. In the United States, staff working in settings outside primary schools tend to have greater preparation in child development, while teachers in primary schools often have more training in academic teaching. The qualification level of these US staff also ranges from lower secondary school level to graduate level and includes, but not always, specialized training in ECE. The minimum qualification required of staff tends to increase with the age of the child they work with, with more staff having ISCED Level 5 and above in the pre-primary year. Leaders in all settings are usually required to have an ISCED Level 5 or above in educational attainment in the pre-primary year. Specific training in leadership and management is rare.

24. Opportunities for continuing professional development are variable in the study countries. For most at the ECED level this is optional, with it becoming a requirement for more senior staff or for those who work in the pre-primary year.

25. Remuneration rates are very different between the study countries and thus cannot be compared across them, although within-country salary levels are usually higher in PPE level settings than ECED settings. In the study countries, staff with higher qualifications and more senior roles are more highly paid, and those who work in public settings are paid more than those working in private settings, as are those working in center-based services compared with home-based services. There is also a differentiation between those who work with children aged from three to six or seven years (PPE) and those who work with children aged under three years (ECED), and even for teachers within these age groups depending on funding sources. Leaders' basic salaries do not always differ from the staff who work directly with children, but additional allowances mean in some cases they may earn considerably more.

26. The majority of study countries nationally regulate group sizes and staff:child ratios in their ECE services. Maximum group size usually changes as the child gets older, with group size steadily increasing year on year, and the number of children per staff member also increasing from birth to three, often stabilizing from age three years to entry to primary schooling. Regulated maximum levels for group size and adult:child ratios across the study countries vary little, except in Chile, 
where children are served in significantly larger groups, with more children per adult.

27. The importance of regulating for health and safety is acknowledged in all the study countries throughout the ISCED Level 0 age phases, with a wide range of aspects being addressed in the regulations, suggesting key concern for the health and wellbeing of the children.

28. The study shows that national curriculum guidance, which usually includes guidance on learning content and learning standards, has been developed for early childhood services in the majority of study countries, and that this is broad in scope and provides specific guidance on learning content, pedagogic approaches, learning goals and assessment. The guidance promotes a broad and balanced range of learning areas to be covered throughout the age phases, with no narrowing of curriculum focus as the child heads towards entry to primary schooling. Countries report both cognitive and non-cognitive areas as included in curriculum guidance at both age phases. All countries reported that a range of pedagogies are encouraged, including more progressive, play-based approaches, and more academic, formal, instructional approaches. This seems to suggest some choice and freedom for settings to develop their preferred approach.

29. It is evident in all the study countries that engaging families and parents in partnerships with ECE programs, and encouraging their active participation in the life of the setting and in the development and education of their child, is a central element in policy strategies.

30. The data suggest that in the study countries inspection is more frequently reported than accreditation as a means to assure quality services at both ECED and PPE levels, although, in the majority of countries, the two processes complement one another; inspection is usually more frequently used to monitor setting quality, with accreditation more frequently used for authorization of setting quality.

31. All the countries that have accreditation and inspection processes promote the results to inform the further development of quality in settings and to establish quality credentials with key bodies, as reflected in the reports. The study countries demonstrate genuine attempts to be transparent and accountable to interested bodies and individuals through the use of reports in development planning, quality improvement, performance management, knowledge creation and transfer, and also to acknowledge and celebrate documented achievements.

\section{Expectations for Child Outcomes}

32. The study countries take a broad view of children's learning and the outcomes that early education settings might support, including a range of cognitive and noncognitive learning outcomes, and do not focus on a narrow range of children's learning outcomes in this phase of education.

33. National child assessments are not commonly conducted in this phase. The findings reveal that assessments, when conducted, are used in the study countries to capture a broad range of learning outcomes, which include cognitive development, executive functioning and social-emotional development and are not narrowly focused solely on areas of traditional or perceived "school readiness", such as literacy and mathematics. The methods of assessment used to capture children's learning 
and development in the study countries are reported to include practitioner observations, standardized tasks and standardized tests, with a mixture of methods prevalent.

34. The findings indicate that child outcomes data are reported to a wide group of recipients, each of whom potentially can use the data to inform the development of educative practice for young children in the home, in the setting, and in the locality, region or country as a whole. The data also indicate that a range of reporting platforms are used, from information and communications technology (ICT), internet websites and other mass dissemination mechanisms, to local, faceto-face interactions, documentation and feedback.

35. The study countries illustrate the potential value of having child outcomes data at a national and subnational level to inform, evaluate and improve system performance, as well as at setting level to inform children's learning plans and setting improvement. However, few countries reported typical national or typical subnational assessments of children's learning and development for children at different stages in ISCED 0 . The countries that reported having typical assessments used the information to inform, evaluate, and improve system performance, and to inform children's learning plans and setting development at the setting level. Some countries (Denmark, Italy and the Russian Federation) do not collect and use child outcomes data for ethical, methodological, and administrative reasons.

Open Access This chapter is distributed under the terms of the Creative Commons AttributionNonCommercial 4.0 International License (http://creativecommons.org/licenses/by-nc/4.0/), which permits any noncommercial use, duplication, adaptation, distribution and reproduction in any medium or format, as long as you give appropriate credit to the original author(s) and the source, provide a link to the Creative Commons license and indicate if changes were made.

The images or other third party material in this chapter are included in the works Creative Commons license, unless indicated otherwise in the credit line; if such material is not included in the works Creative Commons license and the respective action is not permitted by statutory regulation, users will need to obtain permission from the license holder to duplicate, adapt or reproduce the material. 


\section{CHAPTER 2:}

\section{Introduction}

This introductory chapter outlines the background of the Early Childhood Education Study (ECES). It sets out the policy study aims and research questions, and describes the ECES two phase research design. It also identifies the intentions and outputs for the policy module, and the methodology of the policy questionnaire. Finally, it gives basic information on the participating countries and briefly describes how the data in this report are to be presented.

The results discussed in this report are based on data collected in the context of the IEA's ECES. The purpose of this study is to explore, describe and analyze ECE provision and its role in preparing children for the learning and social demands of school and wider society. In particular, the study aims to provide meaningful information for countries, states and jurisdictions across the world on the relationships between policy context, early child education structures and processes, parents' views and expectations, and child outcomes.

The ECES explores ECE policy and its implementation in eight countries. It should be noted that the eight participating countries opted into the study and so cannot be viewed as a representative or purposefully selected sample of country types. Nevertheless, they do provide interesting examples of ECE policy in action in a range of diverse contexts.

The ECES is designed to be conducted in two phases. The first phase of ECES is intended to form the policy context for early child education in the participating countries. As this varies considerably across participating countries, it is planned to feed the outcomes of Phase 1 into the development of the methods to be used in Phase 2. Phase 2 of the study is designed to collect information on children's competencies at the end of early childhood education complemented by contextual data on ECE settings, leaders/ managers, practitioners and parents. While this report discusses the outcomes of Phase 1 (that is, the results of the policy questionnaire), the future implementation of Phase 2 of the study depends on the educational policy and interests of the participating countries.

\section{The Policy Questionnaire}

The results presented in this report were collected using a policy questionnaire addressed to and completed by the National Research Coordinator (NRC) of the eight participating countries between November 2014 and March 2015.

The questionnaire collected basic information about the wider policy context for ECE from birth to the age of primary schooling in each participating country. In particular, it aimed to provide an overview of policy strategies, as well as the systemic and structural results of ECE policy at national and, where necessary, subnational level. Furthermore, its purpose was to capture transnational comparisons in policy and systems, and document key policy changes underway and planned.

More precisely, the policy questionnaire aimed to gather data for the following overarching research questions:

- What are the policy aims for ECE systems?

- What are the key features of ECE systems? 
- What are the main delivery models and providers of ECE?

- What are access and participation levels for children in ECE?

- How is quality regulated and assured in ECE?

- What are the expectations for child outcomes from ECE?

- What key changes are underway or planned in ECE?

- What are the variations in ECE policy, systems, provision, access, quality regulation and child outcomes between countries?

\section{Definition of Early Childhood Education (ECE) Programs}

In the context of the IEA's ECES, ECE has been defined as formal early education and care provision for young children from birth up to the age of primary education. This period is defined under the UNESCO International Standard Classification of Education (ISCED) system as ISCED Level 0 (UNESCO Institute for Statistics, 2012). ISCED Level 0 can be further divided into early childhood educational development programs (ECED) (ISCED Level 0.1) and programs in pre-primary education (PPE) (ISCED Level 0.2).

While ECED programs are designed for younger children usually in the age range birth to three years, PPE programs are aimed for children usually from age three years to the start of primary education (ISCED Level 1). In some education systems, the preprimary education programs may take place during the first stage or cycle of compulsory education and may be located in a primary school. For example, kindergarten in the United States is typically thought of as the beginning of primary schooling, but is included in ISCED level 0. If programs fulfil the criteria for ISCED Level 0, they are covered in this study.

In some countries, pre-primary programs may be located in a primary school and might be linked to ISCED Level 1, while in other countries these years before entry to primary schooling are not part of the educational system. In addition, ECE is often viewed as noncompulsory and can be more locally determined, thus being subject to much more variation in its structures and systems internationally than schooling systems. ECE is also more likely to be devolved to nongovernment bodies, such as religious charities and other private, voluntary and independent providers.

In summary, this report includes:

1. public, private and voluntary ECE provision for children in ISCED Level 0 that falls within a national regulatory framework, i.e. has to comply with a set of rules, minimum standards and/or undergo accreditation procedures;

2. publicly-subsidized and non-subsidized private and voluntary provision;

3. the most common types of ECE provision.

The report does not cover:

1. unregulated home-based provision;

2. settings that operate before or after the main ECE provision, e.g. breakfast clubs, after school clubs and holiday programs;

3. "specialist" provision, e.g. programs integrated into hospitals, orphanages or other such institutions;

4. pilot or experimental ECE provision. 


\section{Participating Countries}

Eight countries participated in the first phase of the ECES and submitted data on their ECE policy for analysis and interpretation: namely, Chile, the Czech Republic, Denmark, Estonia, Italy, Poland, the Russian Federation and the United States (Figure 1).

Figure 1: The study countries

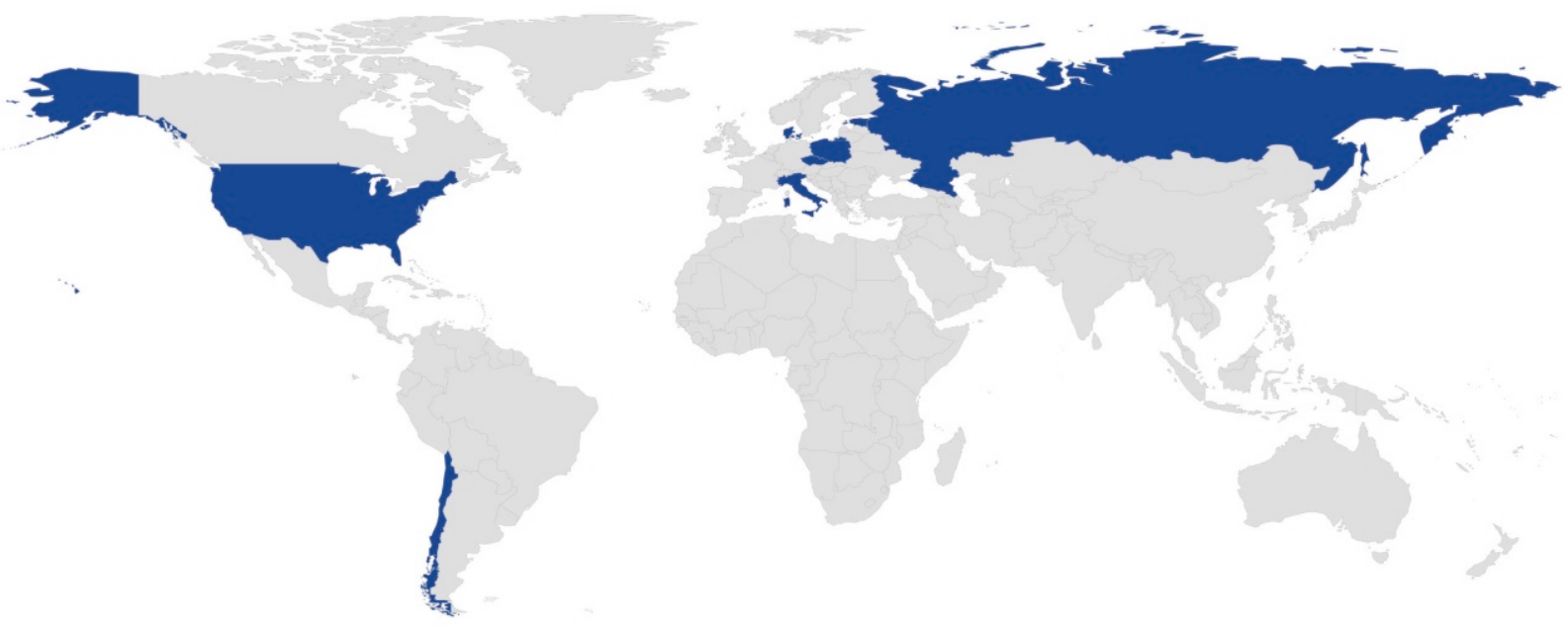

\section{Methodology of the Policy Questionnaire}

Data for the policy report was gathered using an online policy questionnaire that collected information on the wider policy context for ECE (from birth to the age of primary schooling) from each participating country. One questionnaire per country was completed by the NRC (or a country designate) to provide national level evidence; this included questions on:

- Background information about whole educational system

- Public policy

- Delivery models and providers

- Participation and enrollment

- Supporting quality in ECE

- Expectations for child outcomes

Data were collected primarily at a national (country) level but, in questions where there was a need for subnational variations to be acknowledged, data were recorded at either national and/or subnational (state or regional) level. In addition, where there was a wide variation in policy or system provision data were provided that indicated a typical "mid-range" situation, a typical "maximum" situation and a typical "minimum" situation to convey a sense of the range of variation. Lack of accurate data was also recorded.

The policy questionnaire was completed using official documents (recognized by central/government level authorities) as the primary source of information, and also drew on the expertise of ECE specialists and educators as required. In countries where responsibility for ECE was at a regional or local level, information was gathered that was sufficiently representative and the regions covered were specified. In such cases, 
information was provided on an "average" situation across regions, or "maximum/ minimum" situations were indicated. If there were no central data sources or evidence, information about the most common practices was required, supported by references to surveys, analyses and reports. The information provided was the most recent available, and where possible referred to the period 2013/2014.

\section{Structure of the Policy Report}

The policy report begins with a background chapter that gives an overview of the ECE and care systems and structures in the eight participating countries. The main body of the report is then organized in five key sections matching the main areas as addressed in the policy questionnaire. In each of the sections, data from all participating countries are collated and emerging findings are identified, as set out below:

1. Public policy: The aim of this section is to provide information on stated policy aims; the location of responsibility for ECE; the legislative status and statutory entitlements for ECE and care; the statutory entitlements to parental leave and pay; and key policy changes in ECE.

2. Delivery models and providers: The aim of this section is to provide information on policy implementation, such as provider types for different ages of children; whether different providers target different groups of parents/primary care-givers; funding strategies; and transition points and practices and the relationship of early care and education to the school system.

3. Access and participation: The aim of this section is to provide information on the percentage of the preschool population accessing ECE; participation by child characteristics; the diversity of provision and cultural responsiveness; the cost to parents, subsidies, and early intervention programs.

4. Supporting quality in ECE: The aim of this section is to provide information on the regulatory environment; staff qualifications and training; group size and ratios; health, safety, and child protection; ECE curriculum guidance; quality assurance, accreditation, inspection, reporting and accountability.

5. Expectations for child outcomes: The aim of this section is to provide information on expectations for child outcomes for different age groups, whether these are recorded, and how outcome data are used in policy and practice.

The report concludes with a set of individual country profiles, and thorough consideration of the central themes identified as critical for ECE policymakers.

Open Access This chapter is distributed under the terms of the Creative Commons AttributionNonCommercial 4.0 International License (http://creativecommons.org/licenses/by-nc/4.0/), which permits any noncommercial use, duplication, adaptation, distribution and reproduction in any medium or format, as long as you give appropriate credit to the original author(s) and the source, provide a link to the Creative Commons license and indicate if changes were made.

The images or other third party material in this chapter are included in the works Creative Commons license, unless indicated otherwise in the credit line; if such material is not included in the works Creative Commons license and the respective action is not permitted by statutory regulation, users will need to obtain permission from the license holder to duplicate, adapt or reproduce the material. 


\section{CHAPTER 3:}

\section{Overview of the Structures of the Early Childhood Education and Care Systems in the Participating Countries}

The IEA ECES policy report focuses on eight countries that participated in an iterative development and review process to create and evaluate the data presented in this report. It should be noted that, although all of the participating countries continue to further develop their ECE provision and have their own systemic approach to delivering these services, each country is also subject to global demands and developments in ECE, which are impacting on their direction of policy travel. This diverse and dynamic context has led to a complexity in the current structures and systems for ECE in many countries. To set the results of the policy analysis into context, it is important first to understand the basic structure of the ECE system in each of the participating countries.

The aim of this chapter therefore is to provide a short overview of the main features of ECE systems operating in 2014/2015 in the participating countries. It is hoped that this information will enable readers to compare and contrast the different systemic and structural approaches taken by the countries in the study and establish a basis for making transnational comparisons in subsequent chapters. This chapter sets out the structure of the systems, with a particular emphasis on the year before entry into ISCED Level 1.

Further information about educational structures and systems in each of the participating countries can be found in the individual Country Profiles provided in Chapter 9.

\section{Structure of ECE Systems}

Based on the definition of ECE provision as outlined previously and the further distinction into two levels, there are two basic ECE structures:

- a split phase structure, in which provision is delivered in separate settings for younger and older children; and

- a unitary system, where younger and older children are catered for in integrated settings.

In split phase systems, there is a divide between "child care" and "early education," with the early levels being more care and development oriented and the later levels being increasingly oriented towards education. Sometimes an increased emphasis on preparing children for the transition to primary schooling can be found during the final year of PPE programs.

In unitary systems, provision is organized as an integrated offer catering for the whole age phase. Priorities on care and education are more balanced and there are no structural transfers between settings until the children start primary school.

Seven of the eight participating countries have a split ECE system, with either two or sometimes three levels, depending on the age of the children (Figure 2). Estonia is the only country of the eight participating countries with a fully unitary system of education and care for children from birth to primary school entry. The Czech Republic, Italy and 
Poland have a clear distinction between provision for children aged under three years (ECED) and provision for children from three years to the start of primary education (PPE). Chile has three levels of ECE provision based on the age of the children: a Nursery level for children from birth to two years, a Middle level for children aged two to four years, and a Transition level for children aged four to six years. Denmark, the Russian Federation and the United States also offer a form of unitary provision for children from birth till school entry, where settings cater for the whole ISCED Level 0 age range in one setting, and these run in parallel to their split system and extend the system structure options. All study countries reported that there is also regulated and unregulated home-based provision throughout the age phase.

The year before entry to primary school (ISCED Level 1) is of particular interest in this study and structurally this year is the final year of ISCED Level 0. In all countries, ECED provision and most of the PPE programs are noncompulsory, although the final year of PPE provision is compulsory in Chile and Poland. In Chile, the Czech Republic, Denmark, Estonia, Poland, and the Russian Federation, access to PPE in the year before entry to primary schooling is viewed as a universal entitlement. In Italy, it is reported that universal access is promoted, although children might not have the right to a place. It is noncompulsory in the Czech Republic, Denmark, Estonia, Italy, the Russian Federation and the United States. In the United States, it is also compulsory; however, in 45 states and the District of Columbia (DC), school districts are required to provide education (i.e. kindergarten programs) in the final year of ISCED Level 0. The age of the child during this final year before transfer to primary school varies, with it being five to six years of age in Chile, the Czech Republic, Denmark, Italy and the United States. In Estonia and Poland, the age of the children in this year is six to seven years and, in the Russian Federation, it could be at any time between the ages of sixand-a-half years to eight years, according to the school readiness of the child. It should be noted that, as from the school year 2004/2005, all six-year-old children in Poland attended a nursery school (przedszkole) or preschool class (oddzialy przedszkolne) located in primary schools, as the School Education Act (ISN: POL-1991-L-92248) and subsequent revisions introduced a one-year obligatory preschool preparation.

In all eight of the study countries, this final year of ISCED Level 0 is under the auspices of the Ministry/Department of Education and is usually sited in a form of nursery school or preschool (Kindergarten or Second Transition Level in Chile; Materska Skol in the Czech Republic; Aldersintegrerede Institutioner or Bornehaver in Denmark; Koolioelne Lasteasutus in Estonia; Schola dell'Infanzia in Italy; Oddzialy Przedszkolne in Poland; Kindergarten in the United States). In the Russian Federation, this final year can be home-based, center-based, or on primary school sites, all of which are officially approved to offer the pre-primary year.

The number of years covered by the ISCED Level 0 age phase varies between the participating countries (Figure 2). It ranges from six years in Chile, the Czech Republic, Denmark, Italy, Poland and the United States, to up to seven years in Estonia and the Russian Federation. This provides ECE (ISCED Level 0) with a potentially longer time span of a child's life to cover than any other ISCED-defined phase in the educational system, which indicates the significance of this phase of policy for governments in terms of potential impact. 


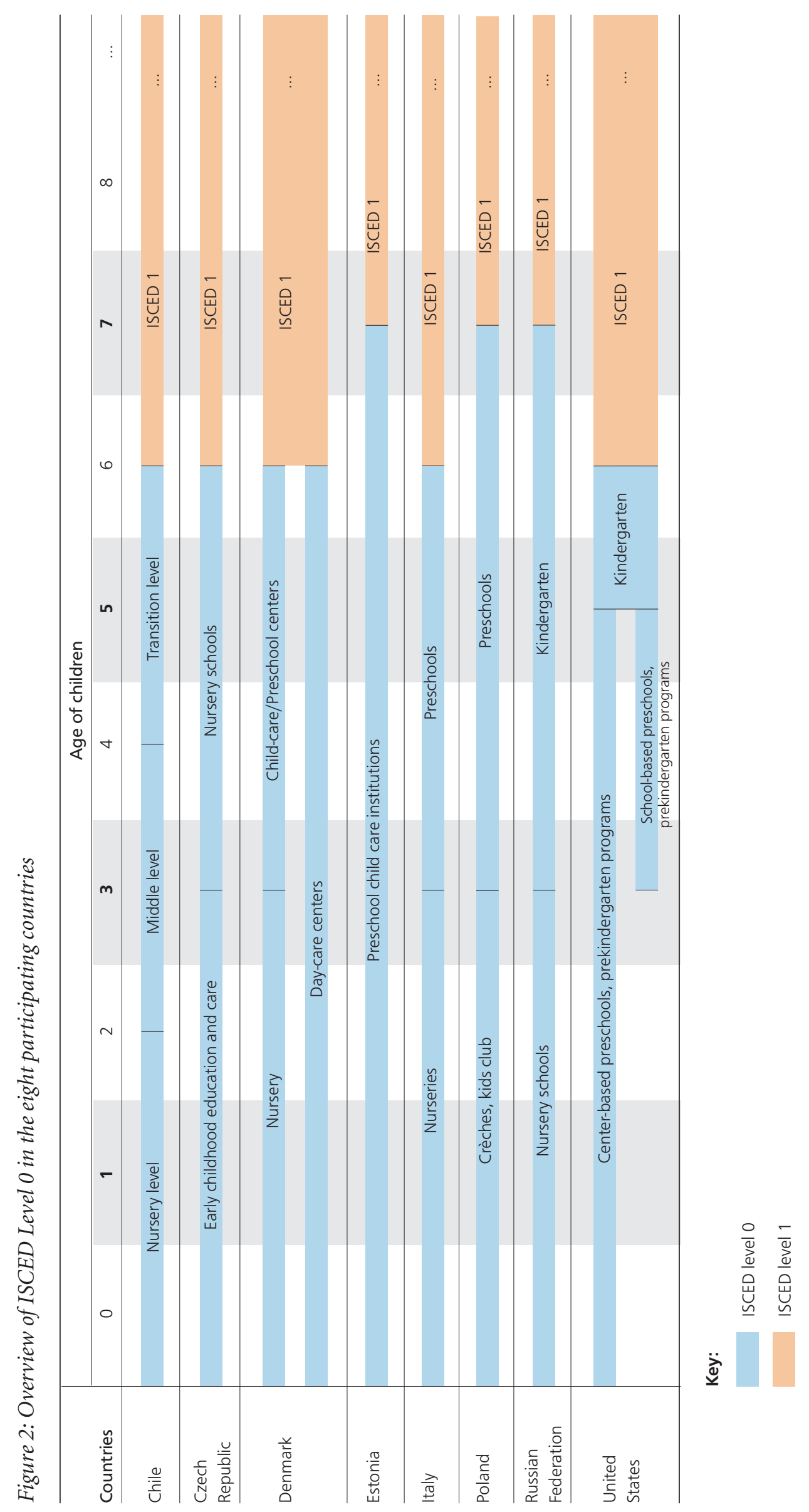


In the countries offering a split system, ECED provision usually covers the first three years of life and PPE covers the adjacent years until the age of transfer to primary schooling. Chile is an exception to this as each of Chile's three ECE phases cover shorter time spans. In the participating countries offering a unitary system, the provision can cover up to seven years.

Depending on each country's ECE system, the number of system transition points varies as children progress through the ECE (ISCED Level 0) system to primary schooling (ISCED Level 1). In countries with a unitary ECE system (Estonia), the child may encounter as few as two transition points (entry from home to the ECE provision and the transfer from ECE provision to primary schooling). The United States system varies, with children encountering as few as two transition points, but in some cases many more.

In countries with a split ECE system, there can be either three or four transition points, depending on the number of stages in ISCED Level 0. The Czech Republic, Denmark, Poland, and the Russian Federation have three transition points: entry from home to ECED provision; transfer from ECED to PPE provision; and transfer from PPE provision to primary schooling. In Chile, four system transition points are possible: entry from home to first ISCED Level 0 provision; transfer from first ISCED Level 0 to second ISCED Level 0 provision; transfer from second ISCED Level 0 to third ISCED Level 0 (pre-primary) provision; and transfer from third ISCED Level 0 to ISCED Level 1 (primary schooling).

Besides these transition points provided by the structure of an ECE system, a child may encounter additional transition experiences if they change setting or attend multiple settings within an age phase. Systemic structures that create multiple settings at each age phase can also mean that, in a single day, a child may experience different physical environments, behavior regimes, friendship groups, curricula, and pedagogies. The evidence from the participating countries reveals that many young children in these countries are experiencing multiple system transitions during their first six to seven years of life and this pattern is very different to children at later stages in the education system where entry to primary or secondary schooling tends to mean entry to one setting for the duration of that age phase.

Enrollment of children in early education and care services in each age phase varies significantly between the study countries, and also changes significantly within countries as the children move from phase to phase (Table 1). For children under three years (ECED), the highest enrollment rate is found in Denmark (67\%) and the lowest in the Czech Republic (5.0\%). There may be a number of reasons for this variability between the study countries at this age, but the level of entitlement to parental leave in the study countries may be a factor in enrollment levels. Between three to five years (PPE) the highest enrollment rate is in Denmark (97.7\%) and Italy (95.1\%), and the lowest in the United States (65.7\%). Again, there may be a number of reasons for these differences, such as the limited availability of provision in some communities and the ease of access to ECE for all children. The significant increase in enrollment of children in ECE as they move between ISCED Level 0 age phases is clear in all study countries (Table 1). 
Table 1: Percentage enrollment in formal care and preschool by age phase in study countries

\begin{tabular}{l|c|c}
\hline \multirow{2}{*}{ Country } & \multicolumn{2}{|c}{ Enrollment in formal care and preschool by age phase (\%) } \\
\cline { 2 - 3 } Chile & Under 3 years & 3 to 5 years \\
\hline Czech Republic & $17.6^{\mathrm{a}}$ & 71.2 \\
\hline Denmark & 5.0 & 76.4 \\
\hline Estonia & 67.0 & 97.7 \\
\hline Italy & 23.3 & 89.6 \\
\hline Poland & 22.8 & 95.1 \\
\hline Russian Federation & 11.2 & 69.2 \\
\hline United States & - & $91.7^{\mathrm{b}}$ \\
\hline
\end{tabular}

Key:

- No data available

Source:

OECD Family Database: PF3.2 Enrolment in child care and preschool (http://www.oecd.org/social/family/ database.htm). Year of reference: 2012.

Explanatory notes:

It should be noted that data in this table may vary slightly from data presented later for some countries where the data sources differed (Table 9), and so the calculation of enrollment levels may have been differently achieved.

Country specific notes:

a Year of reference: 2011 (no data available for 2012).

b Source: UNESCO Institute for Statistics (2014). Year of reference: 2013.

c Year of reference: 2012, numbers are provided by the United States NRC. ECED (under 3 years) includes enrollment in center-based ECE and licensed home-based ECE.

d Year of reference: 2012, numbers are provided by the United States NRC. PPE (3-5 years) includes enrollment in center-based ECE, licensed home-based ECE, and kindergarten.

\section{Parental Leave}

The provision of parental leave during ISCED Level 0 forms a significant element and impacts on most ECE systems as its extent and nature will shape other provision within that system. This is particularly the case during the ECED phase, where ECE provision is often not required until later if the parental leave entitlement is more generous and universally accessed. Although this element of the system is a result of wider social and economic policies, it is complementary to ECE policies and both influences, and is influenced by, the ECE system and so is relevant in this context of this report.

There are usually three types of parental leave described in ECE policy statements. The first is Maternity leave, which is normally available for mothers and has two elements: prenatal (before birth) and postnatal (after birth) and provides leave entitlement for some weeks before the child's birth and also for some weeks after the birth of the child. Paternity leave is normally for fathers and is a shorter leave entitlement that is usually taken directly after the birth of the child. Parental leave follows the end of maternity and paternity leave and is for a defined, and sometimes extended period once other leave entitlements have been used. Usually either the mother or the father can take this entitlement.

The scope and duration of parental leave varies from country to country within the study, with some countries offering substantially more entitlement than others (Figure 3). Sometimes the parental leave is fully paid or partially compensated and sometimes it is not (unpaid). In some cases it is offered to mothers only (maternity leave), sometimes 
to fathers (paternity leave), sometimes to both, and sometimes to either parent (parental leave). All countries in the study, except the United States, have a universal and statutory entitlement to parental leave during ISCED Level 0.

Figure 3: Length of postnatal maternity, paternity and parental leave (in weeks)

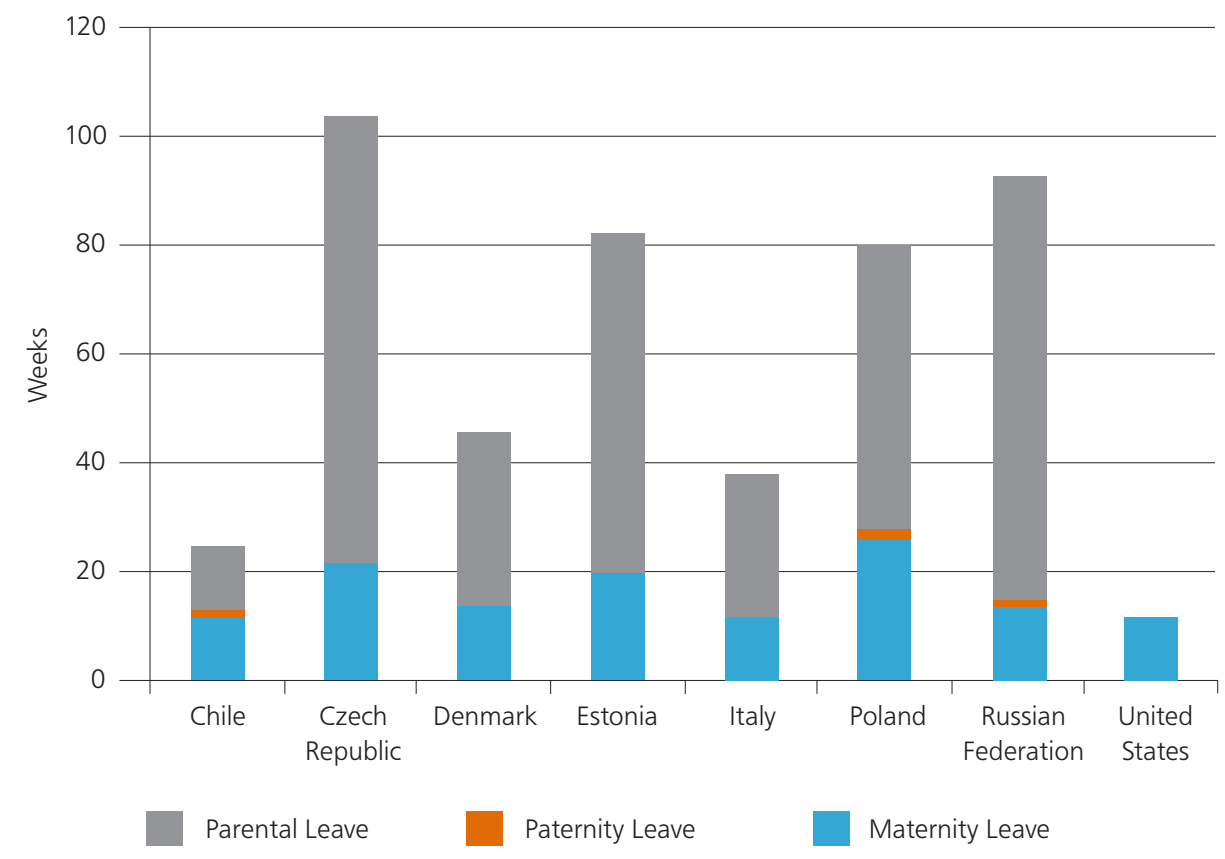

Source:

European Commission/EACEA/Eurydice/Eurostat (2014). Year of reference: 2013.

Explanatory notes:

The figures indicate the accumulated length of the three types of leave in calendar weeks (one year consists of 52 weeks).

Country specific notes:

For Chile, Italy, Poland, Russian Federation, and United States data were provided by the NRCs.

United States: Up to 12 weeks of unpaid, job-protected leave per year including parental leave in all organizations with 50 or more employees.

Russian Federation: An extended maternity leave of 17-22 weeks is available for twins or other multiple births.

In summary, Chile, the Czech Republic, Denmark, Estonia, Poland and the Russian Federation have universal paid maternity leave, ranging from 10 weeks to 26 weeks after birth, although in most countries this entitlement can be extended with reduced payment. In Italy, maternity leave is not universal, but targeted (only for employees, and not for self-employed mothers). The most generous total parental leave entitlements are found in the Czech Republic ( 82 weeks); the Russian Federation (78 weeks) and Estonia (62 weeks), and the shortest (apart from the United States) is found in Chile (24 weeks). Poland and the Russian Federation also offer unpaid maternity leave that can extend the paid entitlement for up to four years. The level of compensation paid to parents on leave also varies between the participating countries, with some offering full salary compensation and others offering only partial compensation.

It should be noted that although there is not a statutory entitlement in the United States, there is the Family and Medical Leave Act (FMLA; US Department of Labor, 1993). The FMLA provides certain employees with up to 12 weeks of unpaid, job-protected leave per year, which includes parental leave. It also requires that group health benefits are 
maintained during the leave. The FMLA applies to all public agencies, all public and private elementary and secondary schools, and companies with 50 or more employees.

In Chile, the Czech Republic, Denmark, and Estonia, the maternity leave entitlement is offered as a leave entitlement that either the mother or father can take. In addition, there is a range of other leave entitlements and rights offered in some countries during both ISCED Level 0 phases, including additional paid or unpaid parental leave under certain circumstances, e.g. child illness, health needs, special needs and disabled children, school meetings (the Czech Republic, Denmark, Italy, Poland, and the Russian Federation), and the right for working mothers to regular work breaks for breastfeeding or feeding young children (Chile, Italy, and Poland). More detail on parental leave entitlements is provided in Chapter 4.

\section{Final Remarks}

When reflecting on the information presented in the rest of this report it should be noted that, as the United States is a federal system, and ECE may be a federal, state or local level responsibility, there is a wide local variation in the ECE systems and structures. This means that, in the context of this report, much of the data from the United States is based on maximum and/or minimum requirements, and thus caution should be exercised when making country-wide generalizations about policy, systems and structures from these data.

It should also be noted that, in July 2015, Italy passed a general education system reform. This law foresees new legislation for the reunification of the split system in order to establish an integrated or unitary ISCED Level 0 system serving children from birth to six years.

In summary, this chapter presents important information that should be taken into account when considering the transnational policy analysis presented in the proceeding chapters. Many system characteristics, such as historical structural divisions, age range coverage, wider social policies, goal orientation of provision, and the number and nature of transition points can affect the challenges associated with developing ECE policy in the contemporary world. Beyond that, clearly the length of access to ECE before entry to ISCED Level 1 varies among countries. The considerable system variation across the eight participating countries summarized in this chapter provides a complex backdrop for considering the alternative possibilities for developing ECE policies for the future, which are set out in the rest of this report.

Open Access This chapter is distributed under the terms of the Creative Commons AttributionNonCommercial 4.0 International License (http://creativecommons.org/licenses/by-nc/4.0/), which permits any noncommercial use, duplication, adaptation, distribution and reproduction in any medium or format, as long as you give appropriate credit to the original author(s) and the source, provide a link to the Creative Commons license and indicate if changes were made.

The images or other third party material in this chapter are included in the works Creative Commons license, unless indicated otherwise in the credit line; if such material is not included in the works Creative Commons license and the respective action is not permitted by statutory regulation, users will need to obtain permission from the license holder to duplicate, adapt or reproduce the material. 


\section{CHAPTER 4: Public Policy}

This chapter presents data on ECE policy at national, regional and local levels, including policy aims; governance and system management; legislative status and statutory entitlements for ECE; statutory entitlements to parental leave and pay; and key policy changes in ECE. These data inform readers about how ECE sits within national systems and what the priorities are for governments, and aim to capture within and between country variations in the way ECE is handled in public policy statements and actions.

\section{Policy Aims}

ECE policy and systems vary widely from country to country and have developed to serve different and multiple aims. For some the main aim may be ensuring school readiness and supporting children's general well-being, healthy socio-emotional development and their sense of citizenship. For others it may be to allow parents to access the labor market, or to support gender equality more widely, or to reinforce cultural values and community cohesiveness, or to ensure less advantaged children have a better start to their lives. These differing goals mean that the early childhood system may be focused on achieving different outcomes for children. Documenting policy aims in countries can help to explain the orientation of ECE services and give a wider perspective to the ECE system.

A recent working paper by the World Bank (2013) and other reviews of international evidence on social mobility (Corak et al., 2012; Pascal, \& Bertram, 2012) showed that, around the world, inequalities in child development are stark. These inequalities are entrenched during a child's early years, so that, by the time children enter primary school, significant gaps exist in the development of socially disadvantaged children and are likely to increase over time. This evidence makes a strong case that ECE policy provides a key opportunity to address inequality and improve outcomes later in life. It also points to a growing body of literature that demonstrates that the returns to investments in children's early years are substantial, particularly when compared to equivalent investments made later in life. The benefits to such investments can accrue to individual children and to society more broadly, and can be leveraged to influence diverse policy objectives, including increasing female labor participation, reaching marginalized populations, and reducing the intergenerational transfer of poverty (Corak et al., 2012; Heckman, 2012).

A further impetus for ECE policy is the growing evidence, mainly from the United Kingdom and the United States, that high quality interventions can advance child development and education in the early years. Random assignment studies of programs such as Perry Preschool, Abecedarian, Infant Health and Development and Nurse-Family Partnerships, and the cohort study, Effective Provision of Pre-school Education (EPPE), have found that high quality ECE programs do have the capacity to significantly improve child health and educational outcomes for disadvantaged children, in both cognitive and non-cognitive domains (Karoly, Kilburn \& Cannon, 2005; Sylva, Melhuish, Sammons, Sirjai-Blatchford, \& Taggart, 2004; Sylva et al., 2008). These results provide grounds for optimism that well-crafted early childhood policies can and should play a key role in narrowing the gaps in school readiness, and, in the longer term, countering the effects of socioeconomic disadvantage. 
Due to this evidence, ECE policy aims have begun to focus more specifically on developing services that enhance child development and outcomes, as well as supporting parent employment (EIU [The Economist Intelligence Unit], 2012; OECD, 2012b). A growing body of research recognizes that ECE can improve children's cognitive abilities and socio-emotional development, help create a foundation for lifelong learning, make children's learning outcomes more equitable, reduce poverty and improve social mobility (Corak et al., 2012; Heckman, 2012; Pascal, \& Bertram, 2012). Consequently, ECE policy is increasingly embedded into anti-poverty or educational equity measures. Today, many governments see ECE as a public investment and high-quality ECE programs are used as an effective tool to help children build a strong foundation for life skills and, therefore, better life trajectories, especially for children from disadvantaged or immigrant backgrounds.

The evidence in these international reports also shows convincingly that there are both short- and long-term economic benefits to taxpayers and the community if high quality early education is available to all children, starting with those who are most disadvantaged. Indeed, universally available early education of a high standard has been shown to benefit everyone and be the most cost-effective economic investment (Heckman, 2012). An independent review (Aos, Lieb, Mayfield, Miller \& Pennucci, 2004) placed the average economic benefits of early education programs for threeand four-year-olds from low-income groups at close to two and a half times the initial investment: these benefits take the form of improved educational attainment, reduced crime and fewer instances of child abuse and neglect. Within this overall figure, there is substantial variation, but reviews of early education programs have noted benefit-tocost ratios as high as 17:1 (Heckman, 2012).

Given this wider evidential context, the ECES explored the range of policy aims found in legislation and official documentation within and between the eight ECES countries (see Table 2).

All eight participating countries are able to identify clear policy aims for ECE, but the range and priority of these aims differs between countries, and sometimes between age phases (Table 2). For example, all countries identify policy aims to support parental employment and training for either ECED or PPE, but in Chile, the Czech Republic and the Russian Federation these aims were less of a priority; for Italy these aims are a priority for ECED but not for PPE. All countries have policy aims to support working parents (with child care; Table 2, columns 1-3), and also aims to support an early education policy agenda (Table 2, columns 4-9). Most countries also identify aims that address wider social and civic issues (Table 2, columns 10, 12 and 14), particularly for PPE, and aims that support early intervention for language needs or special needs, (Table 2, columns 11 and 13). The data suggest that ECE policy is being used to meet a spectrum of social, economic, educational and political demands in all eight study countries, with a core focus on educational/developmental goals.

Closer examination of the data reveals that Chile, Denmark, Estonia and the United States see supporting parental employment as a highly ranked policy aim in ECED and PPE. Support for parental education and training is less strongly identified across the study countries, but still highly ranked in Denmark, Estonia and the United States. Supporting parental work/life balance is viewed as a high policy priority in Denmark and Estonia, and for ECED services in the Russian Federation. This evidence indicates 
Table 2: Stated policy aims for children aged 0-3 years (ECED) and children aged 3 to the start of primary school (PPE)

\begin{tabular}{|c|c|c|c|c|c|c|c|c|c|c|c|c|c|c|c|}
\hline & & \multicolumn{14}{|c|}{ Policy aims } \\
\hline Country & Level & 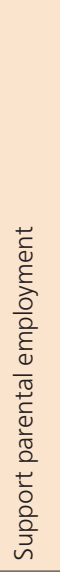 & 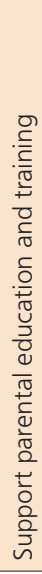 & 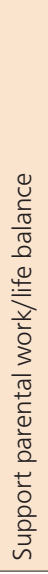 & 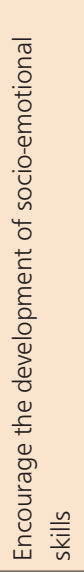 & 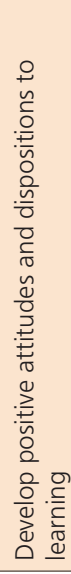 & 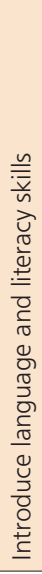 & 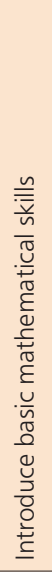 & 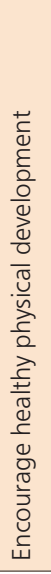 & 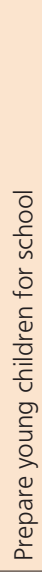 & 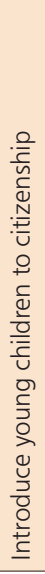 & 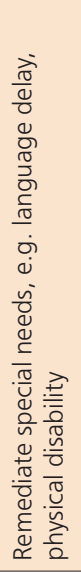 & 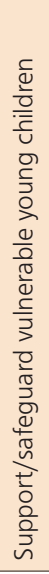 & 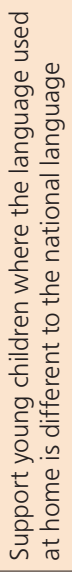 & 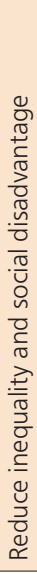 \\
\hline \multirow[t]{2}{*}{ Chile } & ECED & O & O & - & $\bullet$ & $\bullet$ & $\bullet$ & $\bullet$ & $\bullet$ & $\bullet$ & O & - & $\bullet$ & - & $\bullet$ \\
\hline & PPE & $\bullet$ & $\bullet$ & - & $\bullet$ & $\bullet$ & $\bullet$ & $\bullet$ & $\bullet$ & $\bullet$ & - & - & $\bullet$ & - & $\bullet$ \\
\hline \multirow[t]{2}{*}{ Czech Republic } & ECED & 0 & - & 0 & $\bullet$ & $\bullet$ & $\bullet$ & $\bullet$ & $\bullet$ & - & - & - & - & - & - \\
\hline & PPE & O & - & 0 & $\bullet$ & $\bullet$ & $\bullet$ & $\bullet$ & $\bullet$ & - & $\bullet$ & $\bullet$ & $\bullet$ & O & $\bullet$ \\
\hline \multirow[t]{2}{*}{ Denmark } & ECED & $\bullet$ & $\bullet$ & $\bullet$ & $\bullet$ & $\bullet$ & $\bullet$ & $\bullet$ & $\bullet$ & $\bullet$ & $\bullet$ & $\bullet$ & $\bullet$ & $\bullet$ & $\bullet$ \\
\hline & PPE & • & - & $\bullet$ & $\bullet$ & $\bullet$ & $\bullet$ & $\bullet$ & $\bullet$ & $\bullet$ & $\bullet$ & $\bullet$ & $\bullet$ & $\bullet$ & $\bullet$ \\
\hline \multirow[t]{2}{*}{ Estonia } & ECED & $\bullet$ & $\bullet$ & $\bullet$ & $\bullet$ & $\bullet$ & $\bullet$ & $\bullet$ & $\bullet$ & $\bullet$ & $\bullet$ & $\bullet$ & $\bullet$ & ○ & $\bullet$ \\
\hline & PPE & - & - & $\bullet$ & $\bullet$ & $\bullet$ & $\bullet$ & $\bullet$ & $\bullet$ & - & $\bullet$ & $\bullet$ & $\bullet$ & $\bullet$ & $\bullet$ \\
\hline \multirow[t]{2}{*}{ Italy } & ECED & $\bullet$ & - & $\bullet$ & - & - & - & - & - & - & - & O & - & - & - \\
\hline & PPE & - & - & - & $\bullet$ & $\bullet$ & $\bullet$ & $\bullet$ & • & 0 & $\bullet$ & O & 0 & O & $\bullet$ \\
\hline \multirow[t]{2}{*}{ Poland } & ECED & - & - & - & - & - & - & - & - & - & - & - & - & - & - \\
\hline & $\mathrm{PPE}^{\mathrm{a}}$ & 0 & - & - & $\bullet$ & $\bullet$ & 0 & 0 & $\bullet$ & 0 & $\bullet$ & 0 & 0 & - & $\bullet$ \\
\hline \multirow{2}{*}{$\begin{array}{l}\text { Russian } \\
\text { Federation }\end{array}$} & ECED & O & O & $\bullet$ & $\bullet$ & O & 0 & O & $\bullet$ & - & - & $\bullet$ & O & O & $\bullet$ \\
\hline & PPE & $\bullet$ & O & 0 & $\bullet$ & $\bullet$ & $\bullet$ & $\bullet$ & $\bullet$ & $\bullet$ & $\bullet$ & $\bullet$ & $\bullet$ & O & $\bullet$ \\
\hline \multirow[t]{2}{*}{ United States } & ECED & $\bullet$ & • & - & $\bullet$ & $\bullet$ & $\bullet$ & $\bullet$ & $\bullet$ & 0 & $\bullet$ & $\bullet$ & $\bullet$ & $\bullet$ & $\bullet$ \\
\hline & PPE & - b & - & - & $\bullet$ & $\bullet$ & $\bullet$ & $\bullet$ & $\bullet$ & O & $\bullet$ & $\bullet$ & $\bullet$ & $\bullet$ & $\bullet$ \\
\hline
\end{tabular}

Key:

- Highly ranked policy aim.

O Policy aim.

- No policy aim.

\section{Country specific notes:}

a In Poland, there are only very broad policy goals that are briefly stated for ECED; these focus on keeping children safe while parents work and do not constitute an explicit policy goal. The aims also vary in each commune where responsibility to ECE is located.

b In the United States, the policy aim "to support parental employment" at PPE level only applies for the parents of children from three years to not yet in kindergarten (five years).

that the provision of child care to facilitate parental employment and balance work/ life demands continues to be a key policy aim for ECE systems through to the start of primary schooling.

ECE policy in the study countries is also highly concerned with supporting the development and education of the young child; this is also seen as a priority aim in all of the eight study countries, and is especially highly ranked in the PPE phase (three years to start of primary schooling). The high ranking of specific policy aims to support children's socio-emotional development, the development of positive attitudes and 
dispositions, introducing children to language and literacy and basic mathematics, and encouraging healthy physical development reveals that all eight of the study countries aim to provide young children with a balanced educational program (only for PPE in Italy and Poland). This ranking is evident throughout the ISCED Level 0 phase from babyhood to primary school in all countries except Italy, where for under-threes the main aim is to support parental employment.

The policy aim of preparing young children for citizenship is also highly ranked from birth to primary school age in Denmark, Estonia and the United States, and for children from three years old in the Czech Republic, Italy, Poland and the Russian Federation. This evidence reveals that, in the study countries, ECE is viewed as forming a key part in preparing children for their participation in civic society, and this process begins from an early age. All countries (except the Czech Republic and Poland for ECED) also see ECE policy as a key early intervention strategy in identifying and remediating special needs.

The role of the ECE system in addressing wider social issues is also evident in the country policy rankings. All eight study countries identified supporting and safeguarding vulnerable children as an explicit policy aim, with Chile, the Czech Republic, Denmark, Estonia, the Russian Federation and the United States making this a high ranking aim. The contribution of ECE in reducing inequality and social disadvantage was also clear in all study countries, where it was universally highly ranked as an ECE policy aim for PPE services. Supporting children whose home language differs from the national language was also highly ranked as a policy aim in Denmark, Estonia and the United States.

\section{Summary Finding 1}

All eight study countries have a wide range of policy aims for ECE, which include aims to support a child's development and learning agenda, aims to support parental employment and training, aims that address wider social and civic issues, and aims that support early intervention for language needs or special needs. This suggests that ECE policy is being used to meet a spectrum of social, economic, educational, and political demands in all eight study countries, although the emphasis differs among the study countries.

\section{Governance and System Management}

Research indicates that integrating ECE services under one national authority for system governance and management can provide better coordinated and goal-oriented services (Bennett, 2008; OECD, 2012b). However, evidence (Kaga, Bennett, \& Moss, 2010) has also shown that, in practice, administrative and policy responsibility for ECE and care services are often split between two or even more government departments (usually welfare, health and education). Historically, many countries have started out with a "split" system of early childhood services, divided between "(child) care" services, often located in welfare or health departments or ministries, and "early education" services, often located in education departments or ministries. More recently, some countries have moved towards an integrated system where one lead department has responsibility for early education and care services, and, in many cases, this department or ministry is education (for further discussion of this development, see European Commission/EACEA/Eurydice/Eurostat, 2014; Kaga et al., 2010). 
A further complexity is that responsibility for early education and care services may reside in organizational bodies at the state, regional and/or local level. Some research has shown that responsibility at a more local level can have positive results, such as the better integration of ECE services and a greater responsiveness to local needs, but it can also increase differences in access and quality between areas (Kaga et al., 2010).

Given this wider evidential context, the ECES explored the governmental level assigned responsibility for ECE (national, regional, or local level) in the participating countries, and determined which national, regional or local bodies, departments or ministries were responsible for ECE at each different level, and whether this differed between ECED (under-threes) and PPE (three years to primary school) (Table 3).

Table 3: Level of government responsible for setting ECE policy for children aged 0-3 years (ECED) and children aged 3 to the start of primary schooling (PPE)

\begin{tabular}{|c|c|c|c|}
\hline \multirow[b]{2}{*}{ Country } & \multirow[b]{2}{*}{ Level } & \multicolumn{2}{|c|}{ Level at which responsibility for ECE resides } \\
\hline & & $\begin{array}{l}\text { Responsibility for ECE policy } \\
\text { lies mostly at national level }\end{array}$ & $\begin{array}{l}\text { Responsibility for ECE policy lies at } \\
\text { national and subnational level }\end{array}$ \\
\hline \multirow[t]{2}{*}{ Chile } & ECED & $\bullet$ & \\
\hline & PPE & $\bullet$ & \\
\hline \multirow[t]{2}{*}{ Czech Republic } & ECED $^{a}$ & & \\
\hline & PPE & $\bullet$ & \\
\hline \multirow[t]{2}{*}{ Denmark } & ECED & & $\bullet$ \\
\hline & PPE & & $\bullet$ \\
\hline \multirow[t]{2}{*}{ Estonia } & ECED & & $\bullet$ \\
\hline & PPE & & $\bullet$ \\
\hline \multirow[t]{2}{*}{ Italy } & ECED & & $\bullet$ \\
\hline & PPE & & $\bullet$ \\
\hline \multirow[t]{2}{*}{ Poland } & ECED & $\bullet$ & \\
\hline & PPE & & $\bullet$ \\
\hline \multirow{2}{*}{$\begin{array}{l}\text { Russian } \\
\text { Federation }\end{array}$} & ECED & & $\bullet$ \\
\hline & PPE & & $\bullet$ \\
\hline \multirow[t]{2}{*}{ United States } & ECED & & $\bullet$ \\
\hline & PPE & & $\bullet$ \\
\hline
\end{tabular}

Key:

- Level at which responsibility for ECE resides.

\section{Country specific notes:}

a The Czech Republic did not report the existence of a national or subnational body, ministry or department with responsibility for ECED. This was due to the change in the governance of services for the under-threes. For children under three years old, traditional crèches (special health child-care facilities) should have terminated their operation by the end of 2013. These were public facilities, established by cities. They often operated as part of municipal social or health facilities, some of them were affiliated to a nursery school, the others being self-contained. A new act on providing care of children within a group for children from six months of age until the commencement of compulsory school attendance (at six years old) was being prepared. New children groups will be established by employers for use of their employees, or by municipalities, regions and nonprofit organizations. This type of facility should legislatively secure operation of public facilities for children under three years of age. This new act came into effect from 2014 (Czech Act No. 247/2104). In addition, there are a number of "trade" or private child care facilities. These do not receive any state funding and are not bound by any specific legal regulations, hence little is known about their functioning or governance. 
For provision serving children under three years (ECED), all countries except Chile offer governance at both national and subnational levels (Table 3). This means that responsibility for different aspects of ECE governance and system management is distributed between national and subnational bodies.

In Chile, ECED responsibility is located at a national level only, but with responsibilities distributed between a range of national bodies, each concerned with various strategic and operational aspects of the system, such as policy and legislation; quality; regulation, compliance and accountability; and funding and service delivery.

In Denmark, Estonia, Italy, Poland, the Russian Federation and the United States, responsibility is distributed between national and subnational levels. In these countries there is a model of governance for services for under-threes (ECED) with distributed responsibilities for different aspects of policy strategy and operations, indicating an attempt to balance a strategic national policy agenda with more local autonomy, particularly for system delivery and management. For example, in Denmark and Estonia, responsibilities for ECE policy and legislation are located at a national level, while local communities establish and run child care centers and nurseries. In Italy, a similar distribution of responsibilities is reported, but with an additional regional level of governance (responsible also for normative arrangements) with regions, autonomous provinces and individual municipalities having responsibilities for the quality of services and funding mechanisms. In Poland, one national body is responsible for legislation compliance; development of services; information about availability; research and analyses; and local communes are responsible for implementation of the services, including accreditation, admission, and program approach. In the Russian Federation, responsibilities for state policy, educational standards and data collection are located at federal level; responsibilities for supervision, regional system development, financing and child registration are at regional level; and responsibilities for educational program development are at setting level. The United States adopts a similar pattern, with the greatest responsibility for ECE policy being located at state level, but with funding often coming from federal government, provided state programs comply with federal goals. Thus, whilst overall ECED policy is set at federal level, it is implemented by the individual states, counties and school districts. This distributed governance model means that there is variability on specific issues but similarities overall between States on major issues.

For ECE provision serving children from three years to primary school age (PPE), there is greater variation in system governance across the study countries (Table 4), with three countries locating governance responsibilities at a national level (Chile, the Czech Republic, Italy) and five countries locating governance at both national and subnational levels (Denmark, Estonia, Poland, the Russian Federation and the United States).

For those countries offering a single, national level of governance, responsibilities may be located in one national body or distributed across a number of national bodies. For example, in Chile, the system of governance is the same as for its ECED services, with PPE responsibilities distributed between a range of national bodies, each concerned with various strategic and operational aspects of the system, namely policy and legislation, quality, regulation, compliance and accountability, and funding and service delivery. In the Czech Republic, there is just one national body responsible for PPE system governance and management; in Italy there are other bodies with consultation power. 
In those countries offering a mix of national and subnational governance for provision serving children from three years to school age (PPE), there are evident attempts to balance a strategic national policy agenda with more local autonomy, particularly for system delivery and management. In Denmark, Estonia and the Russian Federation, the governance of the PPE system mirrors that of the ECED system, with the same distribution of responsibilities. In the United States, governance is consistent until the kindergarten stage, where policy aims are set at both federal and state level. For example, there are nationally prescribed learning goals for kindergarten through to grade 12 , established by state-member organizations and incentivized by the federal government for adoption by individual states. The federal government, however, is prohibited from establishing learning standards or curricula. In Poland, as a result of administrative reform, national policy (including curriculum development, teacher salaries and regulation) is developed and implemented centrally, while the management of education and the administration of schools, nursery schools and other educational services, including pedagogic supervision, are decentralized to regional educational authorities and communes.

\section{Summary Finding 2}

There is a mix of national and regional or local level governance (national and subnational) for managing the ECE system. This applies, both to provision serving children aged under three years old (ECED) and over three years old (PPE) across the study countries. However, national level governance increases as provision moves towards the pre-primary year and transition to the schooling system. This suggests that for younger children there is more room for local or regional variation in the delivery of services.

The location of responsibility for ECE across government departments or ministries at national level in all countries is influenced by precedent, culture, and evolving structures and systems (Table 4).

Responsibility for ECE policy at national level in both ECED and PPE phases is predominantly spread between multiple ministries or departments, with the most common ministries being education and health in four of the eight participating countries (Chile, Poland, the Russian Federation and the United States) (Table 4). The mix of national ministries or bodies can also differ according to the age phase.

In Denmark, there is one ministry for ECED and PPE, the Ministry of Children, Gender, Integration and Social Affairs, which is a merger of a number of departments into one integrated body that works together with the city councils of the local communities. In the Czech Republic, there is one ministry at ECED level and another at PPE level. At ECED level, responsibility is with the Ministry of Work and Employment and, at PPE level, it is the Ministry of Education.

In countries that have multiple national bodies engaged in ECE system governance there are a wide range of different bodies, reflecting different ECE policy priorities. Two national bodies are involved in Estonia and the United States; three national bodies are involved in Poland; and five or more national bodies are involved in Chile and the Russian Federation (Table 4). In Italy, the responsibility for ECED is at the central level, located within the Ministry of Labor and Social Policies/Welfare. However, this 
Table 4: Bodies or ministries responsible for children aged 0-3 years (ECED) and children aged 3 to the start of primary schooling (PPE)

\begin{tabular}{|c|c|c|c|c|c|c|c|c|c|c|}
\hline \multirow[b]{2}{*}{ Country } & \multirow[b]{2}{*}{ Level } & \multicolumn{9}{|c|}{ Responsible body or ministry } \\
\hline & & 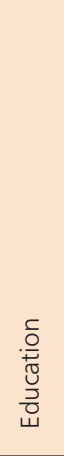 & 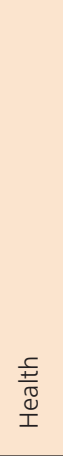 & 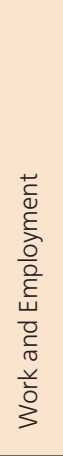 & 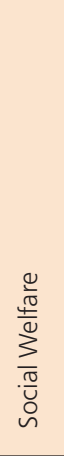 & 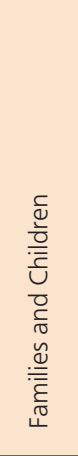 & 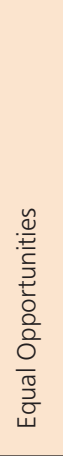 & 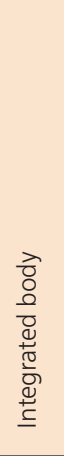 & 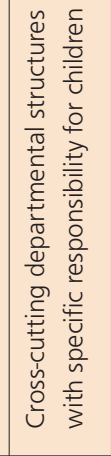 & $\begin{array}{l}\overline{\bar{g}} \\
\bar{t} \\
\end{array}$ \\
\hline \multirow[t]{2}{*}{ Chile } & ECED & $\bullet$ & $\bullet$ & $\bullet$ & $\bullet$ & & & & $\bullet$ & $\bullet$ \\
\hline & PPE & $\bullet$ & $\bullet$ & 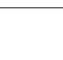 & $\bullet$ & & & & $\bullet$ & $\bullet$ \\
\hline \multirow[t]{2}{*}{ Czech Republic } & ECED & & & $\bullet$ & & & & & & \\
\hline & PPE & $\bullet$ & & & & & & & & \\
\hline \multirow[t]{2}{*}{ Denmark } & ECED & & & & & & & $\bullet$ & & \\
\hline & PPE & & & & & & & $\bullet$ & & \\
\hline \multirow[t]{2}{*}{ Estonia } & ECED & $\bullet$ & & & $\bullet$ & & & & & \\
\hline & PPE & $\bullet$ & & & $\bullet$ & & & & & \\
\hline \multirow[t]{2}{*}{ Italy } & ECED & $\bullet^{a}$ & $\bullet^{b}$ & & & & & $\bullet$ & $\bullet$ & $\bullet$ \\
\hline & PPE & $\bullet$ & $\bullet^{\mathrm{b}}$ & & & & & & & $\bullet$ \\
\hline \multirow[t]{2}{*}{ Poland } & ECED & $\bullet$ & & & & & $\bullet$ & & & \\
\hline & PPE & $\bullet$ & & & & & & & & \\
\hline \multirow{2}{*}{$\begin{array}{l}\text { Russian } \\
\text { Federation }\end{array}$} & ECED & $\bullet$ & $\bullet$ & $\bullet$ & & & & & $\bullet$ & $\bullet$ \\
\hline & PPE & $\bullet$ & $\bullet$ & $\bullet$ & & & & & $\bullet$ & $\bullet$ \\
\hline \multirow[t]{2}{*}{ United States } & ECED & $\bullet$ & $\bullet$ & & & & & & & $\bullet$ \\
\hline & PPE & $\bullet$ & $\bullet$ & & & & & & & $\bullet$ \\
\hline \multicolumn{11}{|c|}{$\begin{array}{l}\text { Key: } \\
\text { - Responsible body. }\end{array}$} \\
\hline $\begin{array}{l}\text { Country specific } \\
\text { Services for chil } \\
\text { the responsibiliti } \\
\text { the Italian Mini }\end{array}$ & ged & & 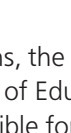 & & & & & & ment & e under \\
\hline
\end{tabular}

level is not the only one in charge of policies for ECED: the Department of Family within the Presidency of the Council of Ministers is also responsible for funding and monitoring ECED policies. In addition, 21 regions and autonomous provinces also hold normative responsibility, with a particular attention to the regulation of both the quality of services and funding mechanisms. Municipalities are a very important part of the funding and management system for ECED and, in some instances, they also regulate their own services with specific normative documents at the local level. In addition, the services for children aged 24-36 months, the so-called "Spring Sections" and anticipated enrollments, are under the responsibility of the Italian Ministry of Education.

In Estonia, responsibility for ECED and PPE policy is shared between the Ministry of Education and the Ministry of Social Welfare. In the United States, there are two main 
national bodies that have responsibility for ECE: US Department of Education and the US Department of Health and Human Services. They coordinate on many aspects of ECED. However, the responsibility for early childhood education and care is shared with the states, where each state also has its own education department and own health and human services department that shape ECE policy from birth through to kindergarten. The US Department of Defense provides early education and care to military families. Additionally, the Bureau of Indian Education oversees early education and care for American Indians, Indian tribes, and Alaska Natives living on reservations. In Poland, ECED responsibility is shared between the Ministry of Health and an integrated body, and for PPE responsibility is the sole responsibility of the Ministry of Education.

For Italy, an integrated system for ECED, with multi-level governance, could best define both the normative and funding responsibility, including the Ministry of Labor and Social Policy/Welfare, Education, Health, and other integrated and cross-cutting departments. For PPE this complexity decreases, with Education, Health and an integrated national body sharing responsibility. The case of Italy illustrates the complexity of collaboration required where multiple national bodies share responsibilities. In Italy, one of the integrated bodies with responsibility for ECED policy is the Department for Family Policies within the Presidency of the Council of Ministries, and this is responsible for the elaboration of the National Plan for family policies and their coordination at national, regional and local level, plus a range of other strategic responsibilities. The Ministry of Labor and Social Policy and other departments also operate in conjunction with the Unified Conference between the state and regions/local authorities. They liaise with the Ministry of Education for the services dedicated to the 24-36 months age range, now mainly under the responsibility of the Ministry of Education. This illustrates that ECED governance is currently very fragmented in Italy, though this situation is expected to change. In July 2015, a general education system reform act was passed (no. 107/2015). This law foresees new legislation for the reunification of the split system in order to establish an integrated or unitary ISCED Level 0 system catering for children from birth to six years. A clearer governance system is in place for PPE, although there are many bodies responsible for this segment too. The Ministry of Education, University and Research is the central authority for educational policies in Italy. Its responsibilities start from the Sezioni Primavera ("Spring" sections, with a bridging function between ECED and PPE within PPE institutions), hosting children aged two to three years and encompassing more generally the Scuole dell'Infanzia (pre-primary schools), for children aged three to six years. The Ministry issues national curriculum guidelines and has responsibility to fund state-owned schools, while supervising the scuole paritarie (schools with equal status, which can be either private or publicly funded).

In the Russian Federation, there are also more than five national bodies sharing responsibility for both ECED and PPE provision, including Education, Health, Work and Employment and other integrated and cross-cutting departments. These bodies have to collaborate on the achievement of Presidential Decree goals. In Chile, six national bodies share responsibility for ECED and PPE policy, including the Ministries of Education, Health, Work and Employment (just ECED), Social Welfare and other cross-cutting departments. Each of these bodies is responsible for different aspects of ECE provision, from providing the permits to open an ECE service, to regulating the administration and the access of families to ECE provision. 


\section{Summary Finding 3}

There is a complex system of governance and system management for ECE in most of the study countries, with distributed responsibilities between different levels in the system, between a range of national bodies or ministries and between different phases during ISCED Level 0 . This complexity is especially evident in the development and delivery of policy for children under three years (ECED), and it challenges policymakers in all study countries to ensure effective communication, clarity of roles and responsibilities, and effective partnership working to ensure the governance and management system supports the development of a coherent early childhood education and care system from birth to primary school entry. Conversely, this complexity and distributed system governance model may have strength in encouraging regional and local participation and autonomy within a national framework, and ensuring ECE services have the flexibility to meet diverse local needs. It also implies a need for collaboration between the different bodies.

\section{Legislative Status and Statutory Entitlements for Children and Parents}

Many countries offer universal free ECE services to certain age groups, usually one or two years before the start of compulsory schooling, and some countries have extended this entitlement to cover younger children as well. However, the level, duration and age eligibility for entitlement to ECE around the world varies markedly between countries, with some children and families in some countries having generous entitlements from an early age, and others having little or no legislative entitlement at all (European Commission/EACEA/Eurydice/Eurostat, 2014; OECD, 2012b).

Given this wider context, the ECES explored the legislative status of ECE and the statutory entitlements of children and parents in the eight study countries, including the age of start to ISCED Level 1, entitlements of children to ECE and entitlements of parents to parental leave and pay.

The age of start to ISCED Level 1 denotes the transfer of children from ECE (ISCED Level 0) to primary schooling; there is littl variance between the study countries on this transition point (Figure 4). This is an important point to note as the maturational and instructional differences between the different levels of education may have implications for interpreting developmental and learning outcomes.

There are two key transition ages for start of ISCED Level 1 in the study countries (Figures 2 and 4). In five countries, the age of transfer to primary schooling is six years of age (Chile, the Czech Republic, Denmark, Italy and the United States) and, in the other three countries, the age of transfer is seven years of age (Estonia, Poland and the Russian Federation). It should be noted that the child transfers to primary schooling usually in the year that they become either six or seven, and so may be slightly younger or older than this transfer age denotes. In addition, in some countries the age of transfer to ISCED Level 1 is flexible according to the assessed school readiness of the child, (for example, in the Russian Federation transfer can occur between the ages of six-and-ahalf and eight years of age), or because they have earlier or delayed entry to primary schooling, (for example, in Italy). It should also be noted that in the period between the data collection and report production, regulation surrounding the age of entry to 
Figure 4: Age of start of ISCED Level 1

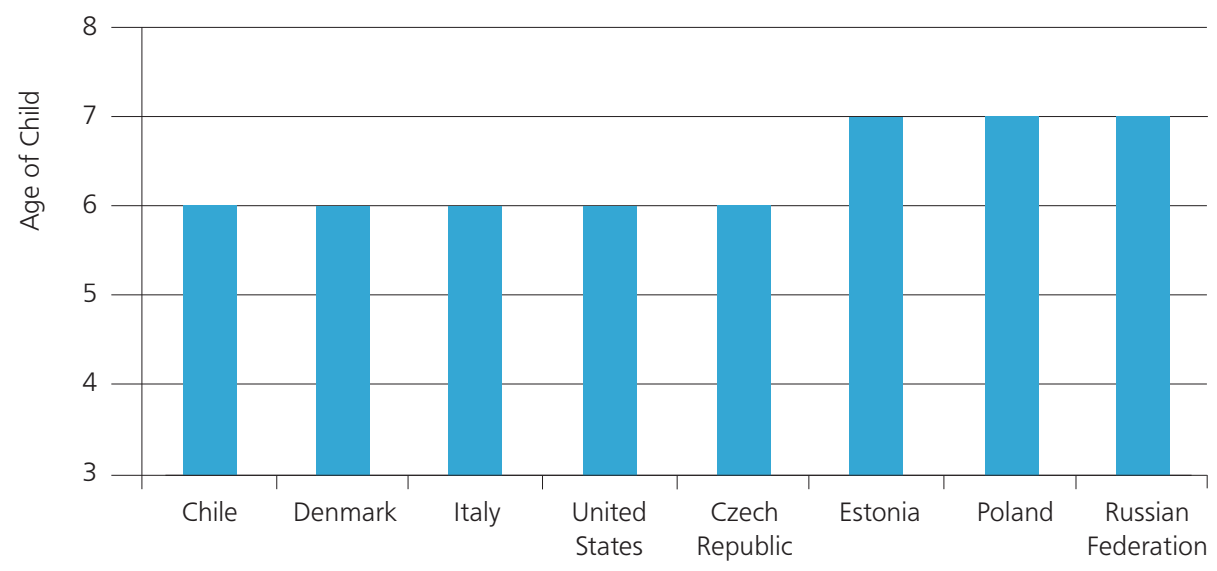

ISCED 1 in Poland underwent two changes. At time of the data collection (in early 2015), Poland was in a transitional period of lowering the age of entry to ISCED Level 1 from seven to six years. During the report production, more precisely in December 2015, the newly-elected government canceled the previous reform and restored the starting age for compulsory education to seven years. In the United States, it is recognized that the year before entry to ISCED level 1 (five to six years) is termed kindergarten; this is usually part of the K-12 educational system (indicating kindergarten for four- to sixyear-olds through to US 12th grade for 17- to 19-year-olds), and so considered the first year of formal education and fully integrated into the school system.

The statutory entitlement to ECE at different phases within ISCED Level 0 varies significantly among the eight study countries (Table 5).

Four of the eight study countries have no statutory entitlements to ECED services for children under the age of three years, namely the Czech Republic, Italy, Poland and the United States (Table 5). Four countries do have statutory entitlement to ECED services for children under three years offering universal entitlement of up to 25 hours a week (Chile, Denmark [25+ hours], Estonia and the Russian Federation), with two offering targeted entitlement to certain populations of up to 25 hours a week (Chile and the Russian Federation). In Chile, from 2014, all children from two years of age are entitled to free access to ECE for 22 hours a week and vulnerable children are entitled to free access for 40 hours a week; those with working mothers have increased entitlement to 55 hours a week from birth. In Denmark, Estonia and the Russian Federation, the entitlement for all children is for much more than 25 hours a week, with some settings in Estonia and the Russian Federation being open 10-12 hours a day, and also at weekends. Although the United States does not have national universal statutory entitlements to ECED programs, it does have national targeted programs: for example, the Early Head Start Program, which targets low-income families who meet specific requirements and targeted programs for children with disabilities.

Italy and the United States have no statutory entitlement to PPE services for children from three years to primary school age (Table 5). However, it should be noted that while there is no statutory entitlement in Italy, there is universal free PPE access of up to 40 hours a week. This is the result of regulations set out in 2009, which established that PPE should be open to all children, including those with disabilities: these regulations are not mandatory, and a child can access a place if it is available and the family chooses 
Table 5: Statutory entitlements to services for children aged 0-3 years (ECED) and children aged 3 to the start of primary school (PPE)

\begin{tabular}{|c|c|c|c|c|c|c|c|}
\hline \multirow[b]{2}{*}{ Country } & \multirow[b]{2}{*}{ Level } & \multicolumn{6}{|c|}{ Statutory entitlements at national or subnational level } \\
\hline & & 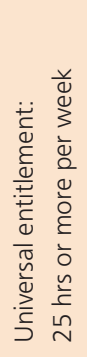 & 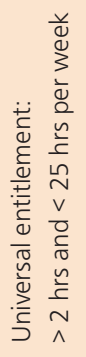 & 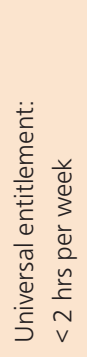 & 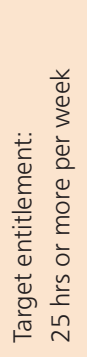 & 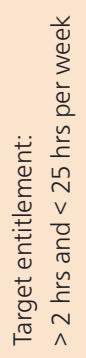 & 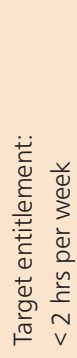 \\
\hline \multirow[t]{2}{*}{ Chile } & ECED & & - & & - & - & \\
\hline & PPE & & $\bullet$ & & - & & \\
\hline \multirow[t]{2}{*}{ Czech Republic } & ECED & $\mathrm{n} / \mathrm{a}$ & $\mathrm{n} / \mathrm{a}$ & $\mathrm{n} / \mathrm{a}$ & $\mathrm{n} / \mathrm{a}$ & $\mathrm{n} / \mathrm{a}$ & $n / a$ \\
\hline & PPE & $\bullet$ & $\bullet$ & & & & \\
\hline \multirow[t]{2}{*}{ Denmark } & ECED & - & & & & & \\
\hline & PPE & - & & & & & \\
\hline \multirow[t]{2}{*}{ Estonia } & ECED & & - & & & & \\
\hline & PPE & & ○ & & & & \\
\hline \multirow[t]{2}{*}{ Italy } & ECED & $\mathrm{n} / \mathrm{a}$ & $n / a$ & $\mathrm{n} / \mathrm{a}$ & $\mathrm{n} / \mathrm{a}$ & $\mathrm{n} / \mathrm{a}$ & $\mathrm{n} / \mathrm{a}$ \\
\hline & PPE & $\mathrm{n} / \mathrm{a}$ & $\mathrm{n} / \mathrm{a}$ & $n / a$ & $\mathrm{n} / \mathrm{a}$ & $\mathrm{n} / \mathrm{a}$ & $\mathrm{n} / \mathrm{a}$ \\
\hline \multirow[t]{2}{*}{ Poland } & ECED & $\mathrm{n} / \mathrm{a}$ & $\mathrm{n} / \mathrm{a}$ & $\mathrm{n} / \mathrm{a}$ & $\mathrm{n} / \mathrm{a}$ & $\mathrm{n} / \mathrm{a}$ & $\mathrm{n} / \mathrm{a}$ \\
\hline & PPE & & - & & & & \\
\hline \multirow{2}{*}{$\begin{array}{l}\text { Russian } \\
\text { Federation }\end{array}$} & ECED & $\bullet$ & $\bullet$ & & $\bullet$ & $\bullet$ & \\
\hline & PPE & - & • & & - & - & \\
\hline \multirow[t]{2}{*}{ United States ${ }^{a}$} & ECED & $\mathrm{n} / \mathrm{a}$ & $\mathrm{n} / \mathrm{a}$ & $n / a$ & $\mathrm{n} / \mathrm{a}$ & $n / a$ & $n / a$ \\
\hline & PPE & $\mathrm{n} / \mathrm{a}$ & $\mathrm{n} / \mathrm{a}$ & $\mathrm{n} / \mathrm{a}$ & $\mathrm{n} / \mathrm{a}$ & $\mathrm{n} / \mathrm{a}$ & $\mathrm{n} / \mathrm{a}$ \\
\hline
\end{tabular}

Key:

- Existence of statutory entitlements at national or subnational level.

$\mathrm{n} / \mathrm{a}$ Statutory entitlement does not exist at national or subnational level.

\section{Country specific notes:}

a In the United States there is not a statutory entitlement to ECED and PPE, but rather targeted eligibility to Head Start programs, disability programs and prekindergarten programs for children who meet certain criteria (see text). However, funding levels do not support the participation of all children eligible to be served in Head Start and prekindergarten. While most children attend kindergarten, it is not mandated in every state.

to do so. The other six study countries all offer statutory universal entitlements to PPE for children from three years to primary school age and, in addition, two countries offer targeted entitlement to certain populations of up to 25 hours a week (Chile and the Russian Federation). In Chile, there is free access to PPE for all children to for 22 hours a week, and for vulnerable children 40 hours a week, extending to 55 hours if the mother works. In Denmark, Estonia and the Russian Federation, there is universal PPE entitlement for up to 10-12 hours per day. In the United States, as with the ECED level, there are no national universal statutory entitlements to PPE programs, but the United States noted two targeted programs: firstly, the Early Head Start Program, which targets low-income families who meet specific requirements and secondly, targeted services for children with disabilities. Additionally, within the United States, at five to six years of age (the year prior to ISCED Level 1) 45 out of 50 states, plus DC, require school 
districts to offer at least a half day of PPE (kindergarten), with 11 of those 25 states (including DC) requiring school districts offer a full-day program.

\section{Summary Finding 4}

Four of the eight study countries have statutory entitlements for children to have access to some level of ECED service, ranging from sessional, to half-day, to full-time programs, with relatively generous levels of entitlement in Denmark, Estonia and the Russian Federation. Six of the eight study countries offer children statutory or universal, non-mandatory entitlement to full-time PPE services in the year before entry to primary schooling, again with relatively generous levels of entitlement in Denmark, Estonia and the Russian Federation. This would seem to be in line with the trend internationally towards a more universal and statutory ECE system, particularly at PPE level (European Commission/EACEA/Eurydice/Eurostat, 2014; OECD, 2012b).

Remunerated parental leave is a key part of family and labor policy in many countries (European Commission/EACEA/Eurydice/Eurostat, 2014; OECD 2012b). All study countries have some level of entitlement to parental leave during the child's first six or seven years (ISCED Level 0), but it is not universally available in Italy or the United States (Table 6). This is mostly available when children are under the age of three years, and those countries with statutory entitlement all continue some degree of parental leave and pay into the PPE phase. All countries offer some level of maternity and paternity leave; sometimes this is universal and sometimes it is targeted, sometimes it is paid and sometimes it is unpaid.

Chile, the Czech Republic, Denmark, Estonia, Poland and the Russian Federation have universal paid maternity leave, ranging from 10 weeks to 26 weeks after birth, although in most countries this entitlement can be extended with reduced payment. The most generous total parental leave entitlements are found in the Czech Republic (82 weeks or more if parents take up their four-year parental leave entitlement), the Russian Federation (78 weeks) and Estonia (62 weeks); of the countries with universal paid maternity leave, Chile offers the shortest entitlement (12 weeks). Poland and the Russian Federation also offer unpaid maternity leave that can extend the paid entitlement for up to four years. The level of compensation paid to parents on leave also varies between the participating countries, with some offering full salary compensation and others offering only partial compensation. The country case studies set out below reveal the complexity of parental leave entitlements in the study countries.

In Chile, according to the Labor Code (Código del Trabajo; see ISN: CHL-2011-L-89227 and ISN: CHL-2002-L-63555), maternity leave for working mothers includes a period of six weeks before the delivery day and 12 weeks after the birth of the child. In 2011, another 12 weeks of parental leave was included. Therefore, in sum, working mothers have 24 weeks of post-partum leave. There is an option for the mother to start working part time after the first 12 weeks after the birth of her child; in this case parental leave is extended for 18 weeks, and mothers receive $50 \%$ of the salary subsidy of maternal leave. Working fathers have the right to paid leave from work of five days from the day of the birth of the child, and fathers can decide how to use those five days. There is no maternity or paternity leave for parents of children at PPE level. After maternity leave, working mothers have the right to one-hour statutory work breaks for breast feeding. 
Table 6: Statutory entitlements to parental leave and pay for parents of children aged 0-3 years (ECED) and children aged 3 to the start of primary school (PPE)

\begin{tabular}{|c|c|c|c|c|c|c|c|c|c|c|}
\hline \multirow[b]{2}{*}{ Country } & \multirow[b]{2}{*}{ Level } & \multirow[b]{2}{*}{ 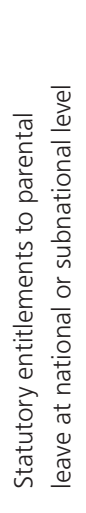 } & \multicolumn{4}{|c|}{ Universal entitlements } & \multicolumn{4}{|c|}{ Targeted entitlements } \\
\hline & & & 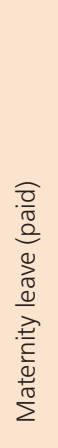 & 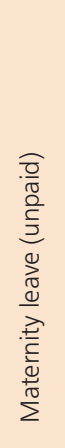 & 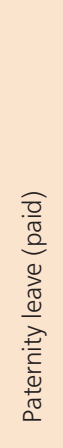 & 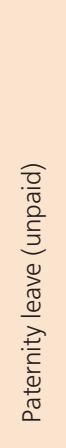 & 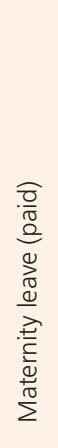 & 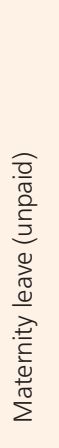 & 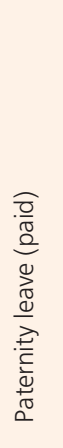 & 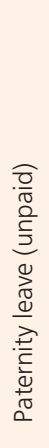 \\
\hline \multirow[t]{2}{*}{ Chile } & ECED & $\diamond$ & $\mathrm{O}$ & O & O & O & $\bullet$ & O & $\bullet$ & O \\
\hline & PPE & $\diamond$ & $\mathrm{n} / \mathrm{a}$ & $\mathrm{n} / \mathrm{a}$ & $\mathrm{n} / \mathrm{a}$ & $\mathrm{n} / \mathrm{a}$ & $\mathrm{n} / \mathrm{a}$ & $\mathrm{n} / \mathrm{a}$ & $\mathrm{n} / \mathrm{a}$ & $\mathrm{n} / \mathrm{a}$ \\
\hline \multirow[t]{2}{*}{ Czech Republic $^{a}$} & ECED & 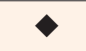 & - & O & - & O & 0 & O & O & O \\
\hline & PPE & 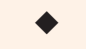 & • & O & - & O & O & O & 0 & O \\
\hline \multirow[t]{2}{*}{ Denmark ${ }^{b}$} & ECED & 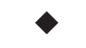 & • & O & $\bullet$ & O & O & $\mathrm{O}$ & O & O \\
\hline & PPE & $>$ & - & O & $\bullet$ & O & $\bullet$ & $\mathrm{O}$ & $\bullet$ & O \\
\hline \multirow[t]{2}{*}{ Estonia } & ECED & $>$ & - & $O$ & • & O & O & • & O & - \\
\hline & PPE & 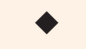 & $\mathrm{O}$ & $\bullet$ & O & • & 0 & • & 0 & • \\
\hline \multirow[t]{2}{*}{ Italyc } & ECED & $\diamond$ & $n / a$ & $\mathrm{n} / \mathrm{a}$ & $\mathrm{n} / \mathrm{a}$ & $\mathrm{n} / \mathrm{a}$ & $\mathrm{n} / \mathrm{a}$ & $\mathrm{n} / \mathrm{a}$ & $n / a$ & $n / a$ \\
\hline & PPE & $\diamond$ & $\mathrm{n} / \mathrm{a}$ & $n / a$ & $\mathrm{n} / \mathrm{a}$ & $\mathrm{n} / \mathrm{a}$ & $\mathrm{n} / \mathrm{a}$ & $\mathrm{n} / \mathrm{a}$ & $n / a$ & $n / a$ \\
\hline \multirow[t]{2}{*}{ Poland } & ECED & $>$ & • & - & - & - & 0 & 0 & 0 & 0 \\
\hline & PPE & $>$ & 0 & ○ & 0 & $\bullet$ & 0 & • & 0 & - \\
\hline \multirow{2}{*}{$\begin{array}{l}\text { Russian } \\
\text { Federation }\end{array}$} & ECED & $>$ & - & $\bullet$ & 0 & • & $\bullet$ & • & • & • \\
\hline & PPE & 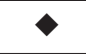 & 0 & 0 & 0 & 0 & • & • & • & - \\
\hline \multirow[t]{2}{*}{ United States $^{d}$} & ECED & $\diamond$ & $\mathrm{n} / \mathrm{a}$ & $\mathrm{n} / \mathrm{a}$ & $\mathrm{n} / \mathrm{a}$ & $\mathrm{n} / \mathrm{a}$ & $\mathrm{n} / \mathrm{a}$ & $\mathrm{n} / \mathrm{a}$ & $\mathrm{n} / \mathrm{a}$ & $\mathrm{n} / \mathrm{a}$ \\
\hline & PPE & $\diamond$ & $\mathrm{n} / \mathrm{a}$ & $n / a$ & $\mathrm{n} / \mathrm{a}$ & $\mathrm{n} / \mathrm{a}$ & $\mathrm{n} / \mathrm{a}$ & $\mathrm{n} / \mathrm{a}$ & $\mathrm{n} / \mathrm{a}$ & $n / a$ \\
\hline
\end{tabular}

Key:

- Existence of statutory entitlements to parental leave at national level.

* Existence of statutory entitlements to parental leave at subnational level.

$\diamond$ No statutory entitlements to universal parental leave at either national or subnational level.

- Universal/targeted entitlement.

O Specific entitlement does not exist.

n/a Data not applicable due to indication of no statutory entitlements.

\section{Country specific notes:}

a There is paid leave for the mother for six months. After this, there is paid leave a mother or father can take for two, three or four years. There is one amount for all and it is up to parents what length they choose (longer leave means a lower amount/month).

b According to the Danish Social Security Act, maternity leave of one year can be shared with the father; parents of children with special needs and adoptive parents are entitled to paid leave to support the child.

c In Italy, there is no statutory universal entitlement, as only employees are entitled to parental leave, and it is not available for self-employed parents.

${ }^{d}$ In the United States, there is no statutory universal entitlement to parental leave and pay but the FMLA provides certain employees with up to 12 weeks of unpaid, job-protected parental leave per year (see Figure 3). 
Furthermore, during the pregnancy period and up to one year after the maternity leave has expired (this excludes the 12 months of parental leave), working mothers benefit from a law that forbids the company to replace or fire them (the "fuero maternal"). If the father decides to use the 12 weeks of parental leave, the "fuero" benefit will apply to the father for a period that doubles the duration of the parental leave, counting from 10 days previous to the beginning of the parental leave. These benefits apply only to mothers (or fathers) that are dependent workers, namely those that have an indefinite contract with a company. People who work independently or who have signed temporary contracts do not qualify for this benefit.

In Estonia, parental leave includes maternity and paternity leave. People have the right to receive parental benefit from the day following the final day of maternity leave. If a mother has no right to maternity leave, the right to the parental benefit starts from the moment her child is born and is paid until the child reaches the age of 18 months. Parental benefit is calculated on the basis of the income which was subject to social tax earned in the calendar year prior to the day on which the right to the benefit arose. If the state pays social tax on behalf of a person, this is not considered to be income from work. Income earned abroad is not subject to social tax in Estonia, and is thus excluded from consideration. If the parent did not work during the year prior to the time at which the right to the benefit arose, the parental benefit is paid at the designated benefit base rate, which, in 2013, was 290 euros.

In Italy, four types of parental leave exist for both ECED and PPE: (1) mandatory maternal, (2) alternative paternal, (3) optional parental, and (4) optional parental for child illness. In the first case, maternal leave in Italy is mandatory for a period of two months prior and three months after birth, and further provision is granted for special cases, such as premature birth, abortion or adoptions. Some flexibility exists within this period under specific circumstances. Only employed mothers are entitled to this leave and public employees have a specific treatment according to national labor contracts for public services. Meanwhile, paternal leave is an alternative for fathers if the following conditions occur: death or severe illness of the mother; mother neglecting child; father's sole custody of the child; or waiver of maternity in special circumstances. The period of paternity leave coincides with that generally granted to mothers. Optional parental leave applies to mothers or fathers for either the first or subsequent year of life of the child (up to the eighth year), and it expires if the parent is no longer an employee. The right can be exercised for a total maximum period of ten months over the first eight years of the child's life. The eleven months leave is an option granted under specific circumstances. During maternal or parental leave, parents of children under three years of age have the right to $30 \%$ of their daily wage/salary. A maximum continuous period of six months usually applies to both mothers and fathers. After the third birthday of the child, the right can still be exercised by parents if they have not used the entire ten-month period, but specific restrictions apply to the calculation of their salary. Autonomous workers, professionals and project workers may also be entitled to parental leave, under specific conditions. At the end of the continuous period of maternity leave, Italian law no. 92/2012 (Riforma del mercato del lavoro) introduces the right to a voucher for babysitting or ECED services. This subsidy applies for the subsequent eleven months of the child's life. In addition, the mother and/or father might also exercise the right to breastfeeding breaks, consisting of a maximum of two daily hours off from work in the case of a daily work schedule of up to six hours. This right entitles mothers/fathers to receive the entire hourly wage the child's first year. Other entitlements exist for childhood illnesses: parents (either the mother or the 
father) are entitled to leave work for the period corresponding to the duration of the illness of any child below three years old. Parents are also entitled to take a maximum of five days per year for illnesses occurring to a child below eight years old.

In Poland, according to the Polish Labor Code (kodeks pracy; ISN: POL-1974-L-45181), each woman has a right to at least 20 weeks of leave (up to 37 weeks in case of multiple births). The six last weeks of this leave can be transferred to the father (this period may be extended if a newborn has serious health problems). The 20-week period can also be extended by another six weeks if requested. Immediately after those 26 weeks, the mother or father can take additional parental leave of up to 26 weeks with a right to $80 \%$ of their salary. Every father also has exclusive right to two weeks of paid leave, which can be used up until the child reaches 12 months. In summary, Poland allows 52 weeks leave (a full year) in total, where only 14 weeks are exclusively for mothers, two for fathers, and remainder may be taken by either parent. Furthermore, each Pole can take optional, unpaid maternity/paternity leave of up to 36 months for each child; this leave must be taken before child reaches five years of age. Within those 36 months, each parent has an exclusive (this right cannot be transferred to another parent) right to one month of leave. If the child is disabled or has serious health issues, then another 36 months of leave are possible, and can be used before the child reaches 18 years of age.

In the Russian Federation, maternity leave with full salary (due to pregnancy and childbirth) is available for 10 weeks before and 10 weeks after childbirth, in case of one child, and for 17-21 weeks in the case of twins or multiple births. Paternity leave (due to childbirth) is available unpaid for five days. Parental leave (for child care) is also available to either of the parents (but only one at a time) or any other adult relative up until the child's third birthday; for a child from birth to eighteen months, this is paid leave; for a child from eighteen months to three years of age, this is unpaid leave. Working women with children under the age of one-and-a-half years have entitlement to breaks for rest and meal breaks to feed the child(ren) of at least 30 minutes duration every three hours. Additional unpaid leave is also available for targeted groups of parents (those with two or more children under the age of fourteen years, or a disabled child under the age of eighteen years old, or a single parent with a child under fourteen years of age). One of the parents (or guardians) is given four additional paid days off per month to care for children with disabilities, which can be used by one person or divided among individuals at their discretion. The same groups also have additional discretionary annual leave without pay of up to 14 calendar days on a collective agreement basis.

In the United States, although not a universal statutory entitlement, the FMLA entitles eligible employees of covered employers to take unpaid, job-protected leave for specified family and medical reasons with continuation of group health insurance coverage under the same terms and conditions as if the employee had not taken leave. Eligible employees are entitled to 12 work weeks of leave in a 12-month period for: the birth of a child and to care for the newborn child within one year of birth; the placement with the employee of a child for adoption or foster care and to care for the newly placed child within one year of placement; to care for the employee's spouse, child, or parent who has a serious health condition; a serious health condition that makes the employee unable to perform the essential functions of his or her job; any qualifying exigency arising out of the fact that the employee's spouse, son, daughter, or parent is a covered military member on "covered active duty;" or twenty-six work-weeks of leave during a 
single 12-month period to care for a covered service member with a serious injury or illness if the eligible employee is the service member's spouse, son, daughter, parent, or next of kin (military caregiver leave) (US Department of Labor, 1993).

\section{Summary Finding 5}

In all the study countries there is an acceptance in national policy that parents, particularly mothers, need to be supported in balancing their work and family commitments, and there is an entitlement to some level of parental leave, usually maternity leave, in the majority of study countries. However, the complexity of eligibility requirements, the limitations on accessing some entitlements, the variable level of salary compensation and the complex timing of the leave entitlements within the study countries create a challenge for parents and employers to navigate and, for policymakers to address if parental leave is to form a coherent and equitable part of an integrated ECE system. This complexity has also been highlighted in other cross-national studies (OECD, 2011, 2013).

\section{Policy Changes}

Evidence in a number of recent studies (EIU, 2012; OECD 2012b; Pascal, \& Bertram, 2012) has shown the dynamic nature of ECE policy and provision worldwide over recent years. The policy aim is generally to ensure greater access to early education, especially to socioeconomically disadvantaged children, and to improve the quality of provision for all. A recent international review of ECE policy in 16 countries, drawn worldwide (Pascal, \& Bertram, 2012), has indicated converging policy initiatives in the following areas:

- More state investment in ECE to secure more equitable access

- More generous staff:child ratios (higher number of staff to the number of children)

- A better trained and qualified ECE workforce

- A regulated and data-evidenced ECE system

- An agreed curriculum, setting out learning goals and pedagogic strategies, for all ECE services

Given this wider context, the ECES explored the key policy changes that have occurred during the last five years (2009-2014), as well as those under consideration or planned within the next five years, within the study countries (Table 7). The intention was to capture the direction of travel for policy, and ascertain the change dynamics for ECE policy in the study countries.

All the study countries, except the Czech Republic, have undergone key policy changes in their services for under-threes (ECED) over the last five years or have significant changes planned for the near future (Table 7). Italy plans the greatest change in ECED provision. In July 2015, Italy passed an education system law (no. 107/2015, par. 181 e) that anticipated future needs to unify the split system for children from birth to six years under the responsibility of the Ministry of Education. Overall, the most dynamic areas of ECED policy change in the study countries are changes in expenditure (seven countries) child:staff ratios (five countries), staff qualifications (five countries), and 
Table 7: Key policy changes for services for children aged 0-3 years (ECED) and children aged 3 to the start of primary school (PPE)

\begin{tabular}{|c|c|c|c|c|c|c|c|c|c|}
\hline Country & Level & 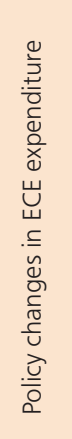 & 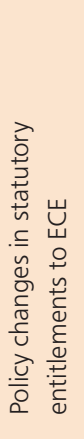 & 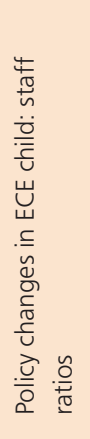 & 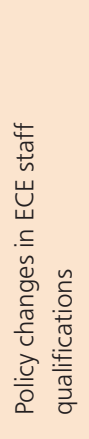 & 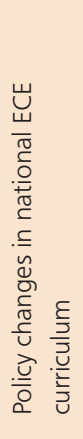 & 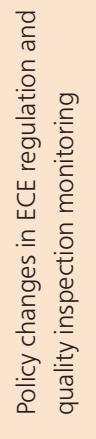 & 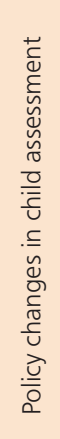 & $\begin{array}{l}\bar{\Phi} \\
\bar{c} \\
\end{array}$ \\
\hline \multirow[t]{2}{*}{ Chile } & ECED & $\bullet$ & $\bullet$ & $\bullet$ & + & + & + & + & + \\
\hline & PPE & $\bullet$ & $\bullet$ & $\bullet$ & + & + & $\bullet$ & O & + \\
\hline \multirow[t]{2}{*}{ Czech Republic } & ECED & O & + & O & O & O & O & ○ & $n / a$ \\
\hline & PPE & + & + & O & O & + & O & 0 & $n / a$ \\
\hline \multirow[t]{2}{*}{ Denmark } & ECED & $\bullet$ & O & O & $\bullet$ & O & O & O & $\bullet$ \\
\hline & PPE & $\bullet$ & O & O & $\bullet$ & O & O & $\bullet$ & $\bullet$ \\
\hline \multirow[t]{2}{*}{ Estonia } & ECED & + & 0 & + & $\bullet$ & $\bullet$ & + & $\bullet$ & + \\
\hline & PPE & + & O & + & $\bullet$ & $\bullet$ & + & $\mathrm{n} / \mathrm{a}$ & + \\
\hline \multirow[t]{2}{*}{ Italy } & ECED & $\bullet$ & + & + & + & + & + & 0 & + \\
\hline & PPE & $\bullet$ & O & $\bullet$ & $\bullet$ & $\bullet$ & $\bullet$ & 0 & + \\
\hline \multirow[t]{2}{*}{ Poland } & ECED & - & 0 & - & - & 0 & $\bullet$ & $\mathrm{n} / \mathrm{a}$ & 0 \\
\hline & PPE & $\bullet$ & $\bullet$ & O & O & $\bullet$ & 0 & $\mathrm{n} / \mathrm{a}$ & 0 \\
\hline \multirow{2}{*}{$\begin{array}{l}\text { Russian } \\
\text { Federation }\end{array}$} & ECED & $\bullet$ & 0 & $\bullet$ & O & $\bullet$ & $\bullet$ & $\bullet$ & $\bullet$ \\
\hline & PPE & $\bullet$ & O & $\bullet$ & O & $\bullet$ & $\bullet$ & $\bullet$ & $\bullet$ \\
\hline \multirow[t]{2}{*}{ United States } & ECED & $\bullet \boldsymbol{+}^{a}$ & O & O & O & $n / a^{b}$ & O & 0 & $n / a$ \\
\hline & PPE & $\bullet \boldsymbol{+}^{a}$ & + & + & + & $n / a^{b}$ & + & + & $n / a$ \\
\hline
\end{tabular}

Key:

No changes in the past five years, and none currently;

- Changes in last five years that have taken place;

+ Planned changes in next five years

n/a Not applicable or no data supplied

\section{Country specific notes:}

a The United States clarified that changes in expenditure have taken place over the last five years (2009-2014) and further changes are planned or being considered for the next five years (2014-2019).

b The United States does not have a national ECE curriculum, therefore the NRC could not address this question. It does, however, have policies in support of what a curriculum should contain.

regulation and quality assurance (five countries). The most commonly planned changes in ECED policy include adult:child staff ratios (three countries), and regulation and quality assurance (three countries).

All eight study countries have also undergone key policy changes in their services for children from three years to primary schooling (PPE) or have significant changes planned for the near future (Table 7). The United States plans the most substantial change in PPE policy. The Czech Republic plans fewest policy changes in PPE. The most dynamic areas of PPE policy change in the study countries are changes in expenditure (eight countries), national PPE curriculum (six countries), staff qualifications (five countries), and regulation and quality assurance (five countries). The most common 
change in PPE policy planned for the near future is an increase in PPE expenditure (three countries).

The most dynamic area of policy change in all the study countries, (except Czech Republic for ECED), was an achieved or planned increase in national ECED and PPE expenditure. In Denmark, for example, a more money initiative has been introduced to increase funding for center-based care and education for children from birth to primary school age. In Italy, new agreements at state and regional level have allocated increased resources to ECE over recent years. In addition a Cohesion Action Plan for 2013-2015 has facilitated the allocation of more resources for ECE in southern Italy. A further measure at PPE level is the 2009 decree, which rationalized schools into comprehensive institutes from PPE to lower secondary. This also modified expenditure on PPE, as many PPE settings were unified into bigger schools, thus cutting the costs of school leadership and other staff.

Chile and Italy reported recent changes in statutory entitlements to ECED services and Italy is planning further change in this area of policy. Chile, the Czech Republic and Poland also reported recent changes in statutory entitlements to PPE services and the United States is planning change in this area of policy. In Chile, for example, a national program entitled "Chile Grows With You" in 2009 changed the national entitlement for ECED for its most vulnerable families, allowing them free access to ECED services for children from the age of two years. In Italy, a comprehensive three-year plan for the development of ECED was introduced in 2007 by the state and the regions and autonomous provinces. The two main objectives of this plan were to increase the availability of places in ECED ("Nidi") and increase the quality of provision. In an additional agreement in 2008, further measures were introduced ensuring participation in ECED of families with multiple (four or more) children. Presidential Decree n. 81/2009 affected PPE in Italy concerning normative arrangements on the rationalization of schools into comprehensive institutions encompassing PPE through lower secondary. This decree also modified expenditure in PPE, since many schools have been unified into bigger schools, thus cutting the overall costs of school leadership and other staff, and affected the number of children per classroom in PPE (minimum 18, maximum 28), so the child:staff ratio has been altered. In the Czech Republic, the last year of PPE is now obligatory.

Chile, Poland and the Russian Federation have recently changed nationally prescribed staff:child ratios for under-threes settings, and Estonia and Italy are planning changes here. Chile, Italy and the Russian Federation have also recently changed nationally prescribed staff:child ratios for PPE settings, and Estonia and the United States are planning changes here. For example, in Chile in 2011, the Ministry of Education passed decree 115, changing staff:child ratios and staff qualification requirements for the first level of ECE (birth to one year) to one professional educator (graduate) to 42 infants and one educator assistant for every seven infants; for the second level (one to two years), one professional educator to 32 children and one educator assistant for every 25 children; for the third level (two to three years), one professional educator and one educator assistant to up to 32 children; for the first transition level (three to four years), one professional educator and one educator assistant for 35 children; and for the second transition level (four to five years), one professional educator and one educator assistant for every 25 children. In Denmark, changes to staff:child ratios are planned, as part of the more money initiative. 
Denmark, Estonia and Poland have recently changed national requirements for ECED staff qualifications, and Chile and Italy are planning changes here. Denmark, Estonia and Italy have also recently changed national requirements for PPE staff qualifications, and Chile and the United States are planning changes. For example, Chile has plans to introduce law that aims to establish a new design and incentives for teacher careers, including new requirements for staff qualifications. In Estonia, there are changes underway to develop teachers' professional preparation to be more open, flexible and practice oriented. A new qualifications framework has been introduced with teacher standards based on a set of identified competencies. These standards will be the basis for teachers' initial and in-service training, as well as career planning. In Italy, a reform of teacher training in 2010 ensured that PPE teachers have to hold a five-year tertiary degree (ISCED Level 5); previously a four-year degree was required.

Denmark, Estonia and Poland reported that there have been developments in their requirements for a national curriculum for the under-threes, and Chile and Italy also have changes planned. (In Denmark, both ECED and PPE have the same regulations for national curriculum requirements.) Estonia, Italy, Poland and the Russian Federation also reported recent developments in their requirements for a national curriculum for children from three to primary school age (PPE), and Chile and the Czech Republic have plans for curriculum changes. The United States could not report here because curriculum matters are decided at state level. It does, however, have policies in support of what a curriculum should contain. In Italy, for example, changes to the national curriculum for under-threes are planned to enhance provision, and ensure services promote child well-being and development, sustain the parental role, and reconcile time for work and care. New curriculum guidelines were issued in 2012 for ECED and PPE, which included new requirements to include teacher observation for child assessment, and a learning program that balances children's play, exploration and expectations for language development, numeracy, logic, time and space, early science and general knowledge of the world. Learning outcomes are also more explicitly defined and there is clear reference to transition to primary school. At present, actions in support of the 2012 curricular guidelines should be launched in PPE in the next six years, divided into three two-year periods.

Poland and the Russian Federation have undergone key changes in the national system for ECED regulation and quality assurance, and Chile, Estonia and Italy are planning changes here. Chile, Italy and the Russian Federation have also made key changes in the national system for regulation and quality assurance for PPE settings, and Chile, Estonia and the United States are planning changes here. For example, in Chile, a new body (Intendance or Directorate of ECE) is to be created within the Superintendence of Education, with the purpose of monitoring ECED and PPE establishments that have official recognition with the Ministry of Education, to ensure compliance with national regulations. In addition, a new law is to be introduced that will propose a national plan for quality assurance of ECE and a system of accreditation under the Quality of Education Agency. In the Russian Federation, there are new norms and a new mechanism for quality assessment of ECED services. In the United States, there are federal regulations for different funding streams, such as the Child Care and Development Block Grants (CCDBG), Individuals with Disabilities Education Act (IDEA) and Title I, which is part of the Elementary and Secondary Education Act (ESEA). As amended, the ESEA provides financial assistance to local educational agencies 
and schools with high numbers or high percentages of children from low-income families to help ensure that all children meet challenging state academic standards. Additionally, within the United States the federal government has supported states in developing their quality rating information systems (QRIS), a systemic approach within the states to assess, improve and communicate the level of quality in early and school age care and education programs. In Italy, a national information system on early childhood education and care services is being implemented through the pilot project named SINSE (Sistema Informativo Nazionale Sui Servizi Socio-Educativi Per La Prima Infanzia: National information system on socio-educational services for early childhood) under the auspices of the Ministry of Labor and Social Policy. The project, coordinated by the Emilia Romagna region, ended in December 2014, and provided a national infrastructure for the census data collection of all early childhood centers (public and private) operating in Italy.

Estonia and the Russian Federation have recently made significant changes to their national ECED child assessment systems, and Chile plans changes. Denmark and the Russian Federation have recently made changes to their national child assessment systems for children over three years (PPE), and Italy and the United States are planning changes. The United States federal government has supported the development of comprehensive assessment systems within the states.

Chile, Denmark, Estonia, Italy and the Russian Federation also reported significant achieved or planned changes in other ECE policy areas. One further key area for change is system governance, where Italy, Russia and Poland reported changes underway. For example, in Italy, a major change was planned for 2015 around the governance of the ECE system, which was formerly a multi-level system under three national bodies (Ministries of Welfare and Labor, Department for Families within the Presidency of the Council of Ministers, and the Ministry of Education). The plan involved a reorganization of entire ECE provision from birth till the age of six years, aimed at integrating the ISCED Level 0 phase and placing it in the portfolio of the Ministry of Education. Fully implemented, this will create a unitary system in Italy, serving children from birth to six years. The aim is to increase access for children to ECED, and introduce regulatory requirements concerning funding, quality, monitoring/evaluation of centers, teacher qualifications, and structural quality indicators (ratios, space) and pedagogy. In Poland, a new law was introduced in 2011 that transferred ECED from the medical domain to the domain of social welfare and family (at ministry level). This incorporated new finance streams and new staff:child ratios.

For PPE, the United States indicated a number of areas with planned changes in the next five years (2014-2019) for ECE, specifically for prekindergarten programs. In terms of children aged three through to not-yet-in-kindergarten who are not in a prekindergarten program and are in some other ECE setting, there are no planned changes in the identified areas. 


\section{Summary Finding 6}

All study countries have recently undergone, or have imminent plans to implement substantial changes in their ECE policy, at both ECED and PPE levels. In particular, increases in public expenditure and enhanced statutory entitlements to ECE services are the most common recent or planned changes. The evidence illustrates the dynamic nature of ECE policy and reflects the growing visibility and importance attached to the development of the ECE systems within all the study countries.

Open Access This chapter is distributed under the terms of the Creative Commons AttributionNonCommercial 4.0 International License (http://creativecommons.org/licenses/by-nc/4.0/), which permits any noncommercial use, duplication, adaptation, distribution and reproduction in any medium or format, as long as you give appropriate credit to the original author(s) and the source, provide a link to the Creative Commons license and indicate if changes were made.

The images or other third party material in this chapter are included in the works Creative Commons license, unless indicated otherwise in the credit line; if such material is not included in the works Creative Commons license and the respective action is not permitted by statutory regulation, users will need to obtain permission from the license holder to duplicate, adapt or reproduce the material. 


\section{CHAPTER 5:}

\section{Delivery Models and Providers}

This chapter describes different ECE delivery models and providers, including setting types for children from birth to six or seven years (ECED and PPE). The data cover the delivery of ECE at different ages within the study countries and by whom, the types and characteristics of provision, target populations for ECE services, setting enrollment rates, setting funding strategies, and support for transitions within the ECE system. Within and between country similarities and variations in service delivery are highlighted.

The variations in ECE delivery models in the study countries identified in this chapter add to the complexity of making comparisons between countries, but they also heighten the degree of interest in those comparisons. When there are variations among countries with respect to such features as system location, provider type, funding, and enrollment levels, straightforward comparisons between different systems and countries are more difficult to make. Thus, readers are cautioned about drawing conclusions concerning the relative strengths of different delivery models and types of provision. However, the information presented can be used to illustrate the wide range of policy choices within the study countries.

\section{Setting Types and Characteristics}

There is considerable diversity in the types of setting that offer ECE in most countries, and the settings serving under-threes (ECED) at times differ in type to those delivering services to over-threes (PPE). Further complexity is found in some countries where, in addition to education and care, ECE settings offer additional or "integrated" services, such as health and family support, which are often focused on assisting disadvantaged families. International studies have highlighted the diversity and complexity of ECE settings across the ISCED Level 0 age phase, particularly for the under-threes (European Commission/EACEA/Eurydice/Eurostat, 2014; OECD, 2012b, 2013). This context means that even identifying distinct and dominant provider types within a country can be challenging. Yet, understanding the range and characteristics of ECE provision for children throughout the ISCED Level 0 phase in different countries provides important information for policymakers when considering how ECE systems are developing.

Given the importance of the ECE delivery system to the development of policy, the ECES explored the range of setting types and characteristics, the age ranges covered, the daily length of provision offered, and setting funding sources in the eight study countries (Tables $8 \mathrm{a}-\mathrm{h}$ ). 


\section{CHILE}

In Chile, there are a wide range of ECE settings called kindergartens that are funded and administered in different ways, and serve different age phases (Table 8a). There are also schools that admit pre-primary children.

Table 8a: Main setting types and characteristics of services for children aged $0-3$ years (ECED) and children aged 3 to the start of primary school (PPE) in Chile

\begin{tabular}{|c|c|c|c|c|c|c|}
\hline \multirow[b]{2}{*}{ Level } & \multirow[b]{2}{*}{ Setting type } & \multirow[b]{2}{*}{ Name in home language } & \multirow{2}{*}{$\begin{array}{l}\text { Serving } \\
\text { children } \\
\text { aged... }\end{array}$} & \multirow{2}{*}{$\begin{array}{c}\text { Typical } \\
\text { length of } \\
\text { day (hours) }\end{array}$} & \multicolumn{2}{|c|}{ Funding type } \\
\hline & & & & & $\begin{array}{l}\text { Publicly } \\
\text { subsidized }\end{array}$ & $\begin{array}{l}\text { Privately } \\
\text { subsidized }\end{array}$ \\
\hline \multirow{6}{*}{ ECED } & ECE JUNJI & Jardines Infantiles JUNJI & $0-3$ years & 11 & $\bullet$ & \\
\hline & $\begin{array}{l}\text { Private or municipality } \\
\text { ECE with a contract } \\
\text { with JUNJI }\end{array}$ & $\begin{array}{l}\text { Jardines Infantiles vía transferencia } \\
\text { de fondo (VFT-JUNJI) }\end{array}$ & $0-3$ years & 11 & $\bullet$ & $\bullet$ \\
\hline & $\begin{array}{l}\text { Communitarian ECE } \\
\text { with contract with } \\
\text { JUNJI }\end{array}$ & $\begin{array}{l}\text { Jardines Infantiles Comunitarios } \\
\text { (JUNJI) }\end{array}$ & $0-3$ years & 11 & $\bullet$ & $\bullet$ \\
\hline & ECE Integra Foundation & Jardines Infantiles Fundación Integra & $0-3$ years & 11 & $\bullet$ & $\bullet$ \\
\hline & $\begin{array}{l}\text { Private ECE with } \\
\text { contract with Integra } \\
\text { Foundation }\end{array}$ & $\begin{array}{l}\text { Jardines Infantiles de administración } \\
\text { delegada (Fundación Integra) }\end{array}$ & $0-3$ years & 11 & $\bullet$ & $\bullet$ \\
\hline & $\begin{array}{l}\text { Private and private } \\
\text { funded ECE }\end{array}$ & $\begin{array}{l}\text { Jardines Infantiles particulares } \\
\text { pagados }\end{array}$ & $0-3$ years & 11 & & $\bullet$ \\
\hline \multirow{9}{*}{ PPE } & ECE JUNJI & Jardines Infantiles JUNJI & $3-6$ years & 11 & $\bullet$ & \\
\hline & $\begin{array}{l}\text { Private and } \\
\text { municipalities ECE with } \\
\text { contract with JUNJI }\end{array}$ & $\begin{array}{l}\text { Jardines Infantiles vía transferencia } \\
\text { de fondos (VTF-JUNJI) }\end{array}$ & $3-6$ years & 11 & $\bullet$ & $\bullet$ \\
\hline & $\begin{array}{l}\text { Communitarian ECE } \\
\text { with contract with } \\
\text { JUNJI }\end{array}$ & $\begin{array}{l}\text { Jardines Infantiles Comunitarios } \\
\text { (JUNJI) }\end{array}$ & $3-6$ years & 11 & $\bullet$ & $\bullet$ \\
\hline & ECE Integra Foundation & Jardines Infantiles Fundación Integra & $3-6$ years & 11 & $\bullet$ & $\bullet$ \\
\hline & $\begin{array}{l}\text { Private ECE with } \\
\text { contract with Integra } \\
\text { Foundation }\end{array}$ & $\begin{array}{l}\text { ardines Infantiles de administración } \\
\text { delegada (Fundación Integra) }\end{array}$ & $3-6$ years & 11 & $\bullet$ & $\bullet$ \\
\hline & $\begin{array}{l}\text { Private and private } \\
\text { funded ECE }\end{array}$ & Jardines Infantiles privados & $3-6$ years & 4 & & $\bullet$ \\
\hline & Public schools & $\begin{array}{l}\text { Establecimientos Escolares } \\
\text { Municipales }\end{array}$ & $4-6$ years & 4 & $\bullet$ & \\
\hline & $\begin{array}{l}\text { Private schools with } \\
\text { public funding }\end{array}$ & $\begin{array}{l}\text { Colegios particulares } \\
\text { subvencionados }\end{array}$ & $4-6$ years & 4 & $\bullet$ & $\bullet$ \\
\hline & $\begin{array}{l}\text { Private schools with } \\
\text { private funding }\end{array}$ & Colegios particulares pagados & $3-6$ years & 4 & & $\bullet$ \\
\hline
\end{tabular}

JUNJI kindergartens or Jardines Infantiles JUNJI are provided by JUNJI (National Board of Kindergartens/Junta Nacional de Jardines Infantiles), which is the main public institution that provides ECE services. These settings are public, free, publicly funded and targeted at children from low-income families. The JUNJI settings provide part and extended day ECE services to children from birth to three years of age or from three to six years of age. They are staffed by professional educators in collaboration with educators' assistants (who have vocational education training). 
Kindergartens via fund transfer or Jardines Infantiles vía transferencia de fondo (VFTJUNJI) are private and municipal settings with a contract with JUNJI. This type of kindergarten includes not-for-profit, private institutions or municipal services that create, maintain and manage ECE services that receive funding from JUNJI. To receive public funding, they must comply with the JUNJI requirements about infrastructure, didactic material and staff qualifications. These settings are funded through a mix of public and private subsidy. They provide part and extended day places to children from birth to three years or from three to six years.

Community kindergartens or Jardines Infantiles Comunitarios (JUNJI) are communitarian ECE settings with a contract with JUNJI. These settings receive a small group of children as a result of a community initiative. They are funded through a mix of public and private funding and provide part or extended day places to children from birth to three years of age or from three to six years of age.

Integra foundation kindergartens (with delegated administration) or Jardines Infantiles de administración delegada (Fundación Integra) are private ECE settings that have a contract with the Integra Foundation. These settings are not-for-profit, private settings that receive funds from Integra Foundation. They are funded through a mix of public and private funding and provide part and extended day places to children from birth to three years of age or from three to six years of age.

Private kindergartens or schools or Jardines Infantiles particulares pagados (at ECED level) or Colegios particulares pagados and Jardines Infantiles privados (at PPE level) are private settings and are privately funded. They only need permission from the municipality to open and from the Health Ministry to certify that they comply with safety requirements. They provide full- and part-time places to children from birth to three years of age or from three to six years of age.

Municipal schools or Establecimientos Escolares Municipales are public schools funded through the municipalities. These schools normally provide primary and secondary education but some of them may have transition levels (prekindergarten and kindergarten) offering PPE. They provide part-time places (typically four hours a day) to children from four to six years of age.

Subsidized private schools or Colegios particulares subvencionados are private schools that receive public funding through a voucher per pupil per attendance. These schools normally provide primary and secondary education, but some of them may have transition levels (prekindergarten and kindergarten) offering PPE. They provide parttime places (typically four hours a day) to children from four to six years of age.

In summary, in Chile, there is a wide range of ECE setting types that fall into two basic types: kindergartens or schools. Most setting types receive a mixture of public and private funding, with some being completely publicly or completely privately funded. The settings also reflect a mix of public, communitarian and private services. Most kindergarten settings offer part and extended day places with long hours, with the school settings generally offering shorter hours. 


\section{CZECH REPUBLIC}

In the Czech Republic there are two main types of ECE settings, nurseries or preschools, with a clear distinction between settings serving under-threes (ECED) and settings serving three- to six-year-olds (PPE) (Table 8b).

Table 8b: Main setting types and characteristics of services for children aged 0-3 years (ECED) and children aged 3 to the start of primary school (PPE) in the Czech Republic

\begin{tabular}{|c|c|c|c|c|c|c|}
\hline \multirow[b]{2}{*}{ Level } & \multirow[b]{2}{*}{ Setting type } & \multirow[b]{2}{*}{ Name in home language } & \multirow{2}{*}{$\begin{array}{l}\text { Serving } \\
\text { children } \\
\text { aged... }\end{array}$} & \multirow{2}{*}{$\begin{array}{c}\text { Typical } \\
\text { length of } \\
\text { day (hours) }\end{array}$} & \multicolumn{2}{|c|}{ Funding type } \\
\hline & & & & & $\begin{array}{c}\text { Publicly } \\
\text { subsidized }\end{array}$ & $\begin{array}{c}\text { Privately } \\
\text { subsidized }\end{array}$ \\
\hline \multirow{2}{*}{ ECED } & Public nursery & Jesle & $0-3$ years & 10 & $\bullet$ & \\
\hline & Private nursery & Jesle & $0-3$ years & 10 & & • \\
\hline \multirow{5}{*}{ PPE } & $\begin{array}{l}\text { Public kindergarten with } \\
\text { municipality as a } \\
\text { responsible body }\end{array}$ & $\begin{array}{l}\text { Veřejná mateřská škola- } \\
\text { zřizovatelem je obec mateřská } \\
\text { škola }\end{array}$ & $3-6$ years & 10 & $\bullet$ & \\
\hline & $\begin{array}{l}\text { Public kindergarten with } \\
\text { regional authority as a } \\
\text { responsible body }\end{array}$ & $\begin{array}{l}\text { Veřejná mateřská škola- } \\
\text { zřizovatelem je kraj mateřská } \\
\text { škola }\end{array}$ & $3-6$ years & 10 & $\bullet$ & \\
\hline & $\begin{array}{l}\text { Public kindergarten with } \\
\text { ministry as a responsible } \\
\text { body }\end{array}$ & $\begin{array}{l}\text { Veřejná mateřská škola- } \\
\text { zřizovatelem je ministerstvo } \\
\text { mateřská škola }\end{array}$ & $3-6$ years & 10 & $\bullet$ & \\
\hline & Private kindergarten & Soukromá mateřská škola & $3-6$ years & 10 & $\bullet$ & $\bullet$ \\
\hline & Church kindergarten & Církevní mateřská škola & $3-6$ years & 10 & $\bullet$ & $\bullet$ \\
\hline
\end{tabular}

Key:

- Funding type exists.

Nurseries or Jesle may be public or privately funded and run. They provide both fulland part-time places to children from birth to three years of age.

Preschools or mateřská škola serve children from three to six years of age (PPE). There are five main types of preschool included on the national preschool register. To be included on the register, a preschool needs to comply with a range of regulations and conditions. Once a preschool is included on this register, it is connected to a state guarantee of quality and it receives public funding. If there is spare capacity, two-yearolds can also enter the setting (according to regulations).

Public kindergartens or Veřejná-zřizovatelem je obec mateřská škola are kindergartens with the municipality as the responsible body. They are publicly funded and provide full- and part-time places to children from three to six years of age.

Public kindergartens or Veřejná-zřizovatelem je kraj mateřská škola are public kindergartens with the regional authority as the responsible body. They are publicly funded and provide full- and part-time places to children from three to six years of age.

Public kindergartens or Veřejná-zřizovatelem je ministerstvo mateřská škola are kindergartens with the ministry as the responsible body. They are publicly funded and provide full- and part-time places to children from three to six years of age.

Private kindergartens or Soukromá mateřská škola. These settings are funded through a mix of public and private funding and provide full- and part-time places to children from three to six years of age. 
Church kindergartens or Církevní mateřská škola. These settings are funded through a mix of public and private funding and provide full- and part-time places to children from three to six years of age.

In summary, in the Czech Republic, there is a wide range of ECE setting types that receive public and private funding, with only one type being completely privately funded. The settings reflect a mix of public and private/church delivered services. Most ECE settings are open full time and for long hours (typically 10 hours a day).

\section{DENMARK}

In Denmark, there is a range of home and center-based ECE settings offering varying hours of operation (Table 8c).

Table 8c: Main setting types and characteristics of services for children aged 0-3 years (ECED) and children aged 3 to the start of primary school (PPE) in Denmark

\begin{tabular}{l|l|l|c|c|c|c}
\hline \multirow{2}{*}{ Level } & \multicolumn{1}{|c|}{ Setting type } & \multicolumn{1}{|c|}{ Name in home language } & $\begin{array}{c}\text { Serving } \\
\text { children } \\
\text { aged... }\end{array}$ & $\begin{array}{c}\text { Typical } \\
\text { length of } \\
\text { day (hours) }\end{array}$ & $\begin{array}{c}\text { Publicly } \\
\text { subsidized }\end{array}$ & $\begin{array}{c}\text { Privately } \\
\text { subsidized }\end{array}$ \\
\hline \multirow{2}{*}{ ECED } & Nursery & Vuggestuer & $0-3$ years & 10 & $\bullet$ & \\
\cline { 2 - 7 } & Home-based care & Dagpleje & $0-3$ years & 10 & $\bullet$ & \\
\hline ECED & $\begin{array}{l}\text { Centers for 0-6-year-old } \\
\text { children }\end{array}$ & Integreret daginstitution & $0-6$ years & 10 & $\bullet$ & \\
\hline PPE & Kindergarten & Børnehaver & $3-6$ years & 10 & $\bullet$ & \\
\hline
\end{tabular}

Key:

- Funding type exists.

Home-based care or Dagpleje are publicly funded, home-based care. They provide part and extended day places to children from birth to three years of age.

Nurseries or Vuggestuer are regulated, publicly funded, center-based settings providing part and extended day places to children from birth to three years of age.

Integrated centers or Integreret daginstitution are publicly-funded centers that cater for children from birth to six years of age. They provide part and extended day places.

Kindergartens or Børnehaver cater for children from three to six years of age. These settings are publicly funded and provide part and extended day places.

In summary, in Denmark there is a range of setting types at both ECED and PPE level, which are all publicly funded. All ECE settings offer part and extended day places, and for long hours (typically 10 hours a day). 


\section{ESTONIA}

In Estonia, a distinction is made between the types of setting within the system. A child care service means a service supporting the ability of the caregiver to cope or work during the provision of which the care, development and safety of a child is guaranteed by a provider of child care service. A preschool child care institution is an educational institution providing care and preschool education to children from eighteen months to seven years of age. In Estonia, there are two main ECE setting types that offer ECE services to children from 18 months to seven years of age with a similar range of hours of operation, namely child care centers, and preschool child care institutions (Table $8 d)$.

Table 8d: Main setting types and characteristics of services for children aged $0-3$ years (ECED) and children aged 3 to the start of primary school (PPE) in Estonia

\begin{tabular}{|c|c|c|c|c|c|c|}
\hline \multirow[b]{2}{*}{ Level } & \multirow[b]{2}{*}{ Setting type } & \multirow[b]{2}{*}{ Name in home language } & \multirow{2}{*}{$\begin{array}{l}\text { Serving } \\
\text { children } \\
\text { aged... }\end{array}$} & \multirow{2}{*}{$\begin{array}{c}\text { Typical } \\
\text { length of } \\
\text { day (hours) }\end{array}$} & \multicolumn{2}{|c|}{ Funding type } \\
\hline & & & & & $\begin{array}{c}\text { Publicly } \\
\text { subsidized }\end{array}$ & $\begin{array}{l}\text { Privately } \\
\text { subsidized }\end{array}$ \\
\hline ECED & Child care service & Lapsehoiuteenus & Birth-7 years & 11 & • & \\
\hline $\begin{array}{l}\text { ECED } \\
\& P P E\end{array}$ & $\begin{array}{l}\text { Preschool child care } \\
\text { institution }\end{array}$ & Koolieelne lasteasutus & $\begin{array}{l}18 \text { months } \\
-7 \text { years }\end{array}$ & 11 & $\bullet$ & \\
\hline
\end{tabular}

Child care centers or Lapsehoiuteenus are publicly funded, integrated centers that offer childcare for children from 18 months to seven years of age. They provide part and extended day places.

Preschool and child care institution or Koolieelne lasteasutus are publicly-funded centers that offer a clear educational program. They provide part and extended day places to children from 18 months to seven years of age.

In summary, in Estonia the two setting types are distinct, one having a child care orientation and the other a preschool orientation, though both types offer care and early education. Both of these setting types are publicly funded and offer part and extended hours places (typically 11 hours a day).

\section{ITALY}

In Italy, there are three main setting types in the ECE system, with a clear distinction between settings that serve children under three years (ECED) and children over three years to the start of primary schooling (PPE): child care nurseries, integrative services and infant schools (Table 8e). They offer varying hours of operation.

Child care nurseries or Nidi d'infanzia are center-based nurseries that can be located in the community or attached to a workplace. Included in this setting type are also micro-nidi, hosting a smaller number of children than nidi. Nidi d'infanzia offer meal services and provide sleeping facilities, if they are operating also during afternoons. They provide part- and full-time places (typically six hours a day) to children from three months up to three years of age. Official statistics on Nidi generally include also services offered in Sezioni primavera/Spring sections for children aged 20-36 months old, even though such services are normally provided within a pre-primary school (PPE setting, type 1). The same statistical treatment is made for the so-called "Anticipi/ Anticipated enrollments" of children aged 30-36 months in pre-primary schools. These 
Table 8e: Main setting types and characteristics of services for children aged 0-3 years (ECED) and children aged 3 to the start of primary school (PPE) in Italy

\begin{tabular}{|c|c|c|c|c|c|c|}
\hline \multirow[b]{2}{*}{ Level } & \multirow[b]{2}{*}{ Setting type } & \multirow[b]{2}{*}{ Name in home language } & \multirow{2}{*}{$\begin{array}{l}\text { Serving } \\
\text { children } \\
\text { aged... }\end{array}$} & \multirow{2}{*}{$\begin{array}{c}\text { Typical } \\
\text { length of } \\
\text { day (hours) }\end{array}$} & \multicolumn{2}{|c|}{ Funding type } \\
\hline & & & & & $\begin{array}{l}\text { Publicly } \\
\text { subsidized }\end{array}$ & $\begin{array}{l}\text { Privately } \\
\text { subsidized }\end{array}$ \\
\hline \multirow{2}{*}{ ECED } & Infant nest & Nidi d'infanzia & $\begin{array}{l}3 \text { months } \\
-3 \text { years }\end{array}$ & 6 & - & • \\
\hline & Integrative services & Servizi integrativi & $\begin{array}{l}3 \text { months } \\
-3 \text { years }\end{array}$ & 5 & $\bullet$ & - \\
\hline PPE & $\begin{array}{l}\text { Infant school } \\
\text { (pre-primary school, } \\
\text { formerly termed } \\
\text { "maternal school") }\end{array}$ & $\begin{array}{l}\text { Scuola dell'infanzia (formerly scuola } \\
\text { materna }\end{array}$ & $3-5$ years & 8 & $\bullet$ & $\bullet$ \\
\hline
\end{tabular}

Key:

- Funding type exists.

settings may be publicly funded, privately funded or receive a mixture of public and private funding.

Integrative services or Servizi integrativi cater for children from three months to three years of age, offering places, typically for five hours a day. Within this type several subtypes of service are included: play spaces (playgrounds) for children from eighteen months to three years, where children are hosted during mornings or afternoons; centers for children and families where children from birth to three years are hosted with their parents or other accompanying adults; services and educational interventions within the family home environment for children under three years of age, run by qualified educational staff.

Infant schools or Scuola dell'infanzia (formerly Scuola Materna) offer early education and may be state-run, municipal or private. These settings may be publicly funded, privately funded or receive a mixture of public and private funding (through parental contributions, charities, business or employee organizations). When state-run, Scuole dell'Infanzia are often part of a comprehensive state institute (Istituto Comprensivo) hosting children within the three to fourteen age range, so crossing ISCED Level 1, Level 2 and Level 3 stages. They generally offer free, full-time places (typically eight hours a day) to children from three to six years of age. State and municipality run settings can also include services offered as sezioni primavera/spring sections for twoto three-year-old children, or anticipi/anticipated enrollments in preschool for children from two-and-a-half to three years. Children admitted in these circumstances can have two time schedule options: six hours a day or an extended 8-9 hours a day.

In summary, in Italy there are three setting types in the ECE system, with some settings solely publicly funded, some solely privately funded, and some receiving a mix of public and private funding. Schools with equal state status (Paritarie) are those run by private providers receiving public funding depending on the meeting of certain requirements. ECE settings generally operate for between five and eight hours, with some also offering extended hours. 


\section{POLAND}

In Poland, there is a range of setting types in the ECE system, with a clear distinction between setting types at ECED and PPE. ECE settings vary from home-based child care to more formalized centers, kindergartens or schools. They vary in terms of hours of operation, with some offering long, extended hours and others shorter days (Table 8f).

Table 8f: Main setting types and characteristics of services for children aged $0-3$ years (ECED) and children aged 3 to the start of primary school (PPE) in Poland

\begin{tabular}{|c|c|c|c|c|c|c|}
\hline \multirow[b]{2}{*}{ Level } & \multirow[b]{2}{*}{ Setting type } & \multirow[b]{2}{*}{ Name in home language } & \multirow{2}{*}{$\begin{array}{l}\text { Serving } \\
\text { children } \\
\text { aged... }\end{array}$} & \multirow{2}{*}{$\begin{array}{l}\text { Typical } \\
\text { length of } \\
\text { day (hours) }\end{array}$} & \multicolumn{2}{|c|}{ Funding type } \\
\hline & & & & & $\begin{array}{c}\text { Publicly } \\
\text { subsidized }\end{array}$ & $\begin{array}{l}\text { Privately } \\
\text { subsidized }\end{array}$ \\
\hline \multirow{4}{*}{ ECED } & Crèche & Żłobek & $\begin{array}{c}5 \text { months- } \\
3 \text { years }\end{array}$ & 10 & $\bullet$ & $\bullet$ \\
\hline & Kids club & Klub dzieçiecy & $1-3$ years & 5 & $\bullet$ & $\bullet$ \\
\hline & Day care & Dzienny opiekun & $\begin{array}{c}5 \text { months- } \\
3 \text { years }\end{array}$ & 5 & $\bullet$ & $\bullet$ \\
\hline & Nanny & Niania & $\begin{array}{l}5 \text { months- } \\
3 \text { years }\end{array}$ & 8 & & $\bullet$ \\
\hline \multirow{3}{*}{ PPE } & $\begin{array}{l}\text { Kindergartens (in some } \\
\text { works described also as } \\
\text { nursery schools) }\end{array}$ & Przedszkole & $3-7$ years & 11 & $\bullet$ & $\bullet$ \\
\hline & $\begin{array}{l}\text { Preschool classes in } \\
\text { primary schools }\end{array}$ & $\begin{array}{l}\text { Oddział przedszkolny w szkole } \\
\text { podstawowej }\end{array}$ & $3-7$ years & 5 & $\bullet$ & $\bullet$ \\
\hline & $\begin{array}{l}\text { Other preschool settings, } \\
\text { including preschool } \\
\text { units and centers }\end{array}$ & $\begin{array}{l}\text { Inne formy wychowania } \\
\text { przedszkolnego: punkty } \\
\text { przedszkolne i zespoły wychowania } \\
\text { przedszkolnego }\end{array}$ & $3-7$ years & 5 & $\bullet$ & $\bullet$ \\
\hline
\end{tabular}

Key:

- Funding type exists.

Home-based care can take two forms; firstly, dzienny opiekun or day care delivered by a person appointed by a commune, who can care for up to five children in their home or in a place provided by the commune. They are financed through a mix of public and private funding and provide part-time places to children from five months to three years of age. The second form of home-based care is niania or nanny, where one person (usually registered) looks after one child and is appointed and paid in full by the parents, but his/her social insurance is covered by the government in full or in part. Nannies provide full-time services to children from five months to three years of age.

Center-based care can take two forms; firstly, żłobek or crèche, which is the oldest and most regulated form of ECE in Poland, (for example, if the number of children in the crèche exceeds 20 , then a qualified nurse has to be appointed). Crèches may be administered by communes as a public service or by other institutions, selected through an open competition. They can be financed through a mix of public and private funding and provide part- and full-day places to children from five months to three years of age. The second type of center-based settings are called klub dziecicy, or kids clubs, and are a smaller and less regulated version of crèches. Kids clubs are a relatively new entity and may be administered by communes as a public service or by other institutions, selected through an open competition. They can be financed through a mix of public and private funding, and provide half-day places to children from one to three years of age. 
Kindergartens or Przedszkole (sometimes called nursery schools). There are two additional subtypes of kindergartens: those with integrated units and special kindergartens for children with disabilities. They may be publicly or privately funded, or a mixture of these and provide full- and part-time places to children from three to seven years of age.

Preschool classes in primary schools or Oddział przedszkolny w szkole podstawowej are intended primarily to provide compulsory preschool places for children from five years of age, before entry to primary school at seven years of age. They may be financed through a mix of public and private funding and offer part-time places (typically five hours a day) to children from three to seven years of age. Currently these units are being transitioned into regular nursery schools or other preschool settings.

Preschool units or Inne formy wychowania przedszkolnego: punkty przedszkolne $i$ zespoly wychowania przedszkolnego include other kinds of preschool settings, including preschool units and centers. Preschool units are intended as smaller "light" versions of nursery schools, there is a limit of 25 children per setting and also organizational regulations are less strict. Nursery centers are similar to preschool units, but can operate on only selected days of a week. They may be funded through a mix of public and private funding, usually through a public subsidy given for each child to communes from the Ministry of Education, which is often supplemented from the settings own private funding. Public settings (run by communes) and private settings (run by other entities) receive the same subsidy.

In summary, in Poland, there is a range of setting types at both ECED and PPE. All setting types receive public and private funding. Most ECE settings offer full- and parttime services, with some offering an extended day.

\section{THE RUSSIAN FEDERATION}

In the Russian Federation, there is a wide range of setting types in the ECE system. Over recent years the emergence of the autonomy of education establishments has been accompanied by growth in their variety. Preschool kindergartens are now differentiated by specialism, and so can be child development kindergartens (prioritizing an aspect of child development); compensatory kindergartens (prioritizing the correction of abnormalities in children's development); health improvement kindergartens (prioritizing sanitation, hygiene, and health improvement); or combined kindergartens (which can include general development, compensatory and health improvement services in various combinations). Preschool education centers and full-day kindergartens attendance remain the basic form of preschool education, but new forms of non-state preschool education are also being sought that increase opportunities for families to choose the form of their children's preschool education; for example, Sunday kindergartens, family kindergartens, short-stay children's groups, development groups, and family education centers. Supplementary education offers still more education services for preschool age children. ECE settings vary from small informal child care groups to more formalized centers or kindergartens. They vary in terms of hours of operation, with some offering extended hours, and others half-day provision (Table $8 \mathrm{~g})$. 
Table 8g: Main setting types and characteristics of services for children aged 0-3 years (ECED) and children aged 3 to the start of primary school (PPE) in the Russian Federation

\begin{tabular}{|c|c|c|c|c|c|c|}
\hline \multirow[b]{2}{*}{ Level } & \multirow[b]{2}{*}{ Setting type } & \multirow[b]{2}{*}{ Name in home language } & \multirow{2}{*}{$\begin{array}{l}\text { Serving } \\
\text { children } \\
\text { aged... }\end{array}$} & \multirow{2}{*}{$\begin{array}{l}\text { Typical } \\
\text { length of } \\
\text { day (hours) }\end{array}$} & \multicolumn{2}{|c|}{ Funding type } \\
\hline & & & & & $\begin{array}{c}\text { Publicly } \\
\text { subsidized }\end{array}$ & $\begin{array}{l}\text { Privately } \\
\text { subsidized }\end{array}$ \\
\hline \multirow{6}{*}{ ECED } & $\begin{array}{l}\text { Public full-time group } \\
\text { for children }\end{array}$ & $\begin{array}{l}\text { Группа детей раннег } \\
\text { возраста в государственном } \\
\text { образовательном учреждении }\end{array}$ & $\begin{array}{l}2 \text { months } \\
-3 \text { years }\end{array}$ & 12 & $\bullet$ & \\
\hline & $\begin{array}{l}\text { Public part-time } \\
\text { group for children }\end{array}$ & $\begin{array}{l}\text { Группа кратковременного } \\
\text { пребывания в государственном } \\
\text { образовательномучреждени }\end{array}$ & $\begin{array}{l}2 \text { months } \\
-3 \text { years }\end{array}$ & 4 & $\bullet$ & \\
\hline & $\begin{array}{l}\text { Non-public full-time } \\
\text { group for children }\end{array}$ & $\begin{array}{l}\text { Группа детей раннег } \\
\text { раннего возраста в } \\
\text { негосударственном } \\
\text { образовательном учреждении }\end{array}$ & $0-3$ years & 12 & $\bullet$ & $\bullet$ \\
\hline & Non-public part-time & $\begin{array}{l}\text { Группа кратковременного } \\
\text { пребывания в } \\
\text { негосударственном } \\
\text { образовательномучеждении/ } \\
\text { Short stay group in state educational } \\
\text { institution }\end{array}$ & $\begin{array}{l}2 \text { months } \\
-3 \text { years }\end{array}$ & 4 & - & $\bullet$ \\
\hline & $\begin{array}{l}\text { Group for children } \\
\text { individual entrepreneur }\end{array}$ & $\begin{array}{l}\text { Дошкольное образование у } \\
\text { индивидуальных } \\
\text { предпринимателей }\end{array}$ & $\begin{array}{l}2 \text { months } \\
-3 \text { years }\end{array}$ & $4-24$ & $\bullet$ & $\bullet$ \\
\hline & Child care group & Присмотр и уход & $\begin{array}{l}2 \text { months } \\
-3 \text { years }\end{array}$ & $4-12$ & $\bullet$ & $\bullet$ \\
\hline \multirow[t]{3}{*}{ PPE } & $\begin{array}{l}\text { Public full-time group } \\
\text { for children }\end{array}$ & $\begin{array}{l}\text { Государственный } \\
\text { детский сад в режиме } \\
\text { полногодня }\end{array}$ & $3-7$ years & 12 & - & $\bullet$ \\
\hline & $\begin{array}{l}\text { Non-public group } \\
\text { for children }\end{array}$ & $\begin{array}{l}\text { Негосударственный } \\
\text { детскийсад }\end{array}$ & $3-7$ years & 12 & $\bullet$ & $\bullet$ \\
\hline & Child care group & Присмотр и уход & $3-7$ years & 4 & • & • \\
\hline
\end{tabular}

Key:

Public kindergartens can be provided by the state or the municipality, are publicly funded, and provide full-time or part-time places to children from two months to seven years of age. These groups can be organized with inclusion or as a special group for children with disabilities.

Non-public kindergartens operate in a state educational institution. They are funded through a mix of public and private funding, and provide full-time (12 hours), shorter working hours ( $8-10.5$ hours), extended day (13-14 hours), part-time ( $3-5$ hours) and 24-hour services for a five- or six-day working week, for children from three to seven years of age.

Private kindergartens owned by an individual entrepreneur, are funded through a mix of public and private funding, and provide both full-time and part-time places (typically from 4 to 12 hours) for children from two months to three years of age.

Child care groups do not offer a defined educational program. They are funded through a mix of public and private funding, and provide full-time (12 hours), shorter working hours ( $8-10.5$ hours), extended day (13-14 hours), part-time (3-5 hours) and 24-hour coverage for a five- or six-day working week, for children from two months to three years of age. 
In summary, in the Russian Federation, there are a wide range of setting types at both ECED and PPE level financed through a mix of public and private funding. Most ECE settings offer full- and part-time services, with some settings offering extended opening hours, up to 24 hours.

\section{THE UNITED STATES}

In the United States, ECE includes a wide range of settings. Settings vary in terms of location, from private homes to more formalized settings, such as centers or within schools. They vary in terms of hours of operations, with some more than covering the work day and others more tailored to half day provision. ECE within the United States has several different names, such as child care, day care, preschool, prekindergarten, and transitional kindergarten. There are different ways to distill the variety of setting types into broader categorization. One differentiation that is often used in the United States is location. Therefore, for reporting purposes for this study, the United States provided information on children's participation in the following: center-based ECE; home-based ECE; and kindergarten (Table 8h).

Table 8h: Main setting types and characteristics of services for children aged 0-3 years (ECED) and children aged 3 to the start of primary school (PPE) in the United States

\begin{tabular}{|c|c|c|c|c|c|}
\hline \multirow[b]{2}{*}{ Level } & \multirow[b]{2}{*}{ Setting type } & \multirow{2}{*}{$\begin{array}{l}\text { Serving } \\
\text { children } \\
\text { aged... }\end{array}$} & \multirow{2}{*}{$\begin{array}{c}\text { Typical } \\
\text { length of } \\
\text { day (hours) }\end{array}$} & \multicolumn{2}{|c|}{ Funding type } \\
\hline & & & & $\begin{array}{l}\text { Publicly } \\
\text { subsidized }\end{array}$ & $\begin{array}{l}\text { Privately } \\
\text { subsidized }\end{array}$ \\
\hline \multirow[b]{2}{*}{ ECED } & Center-based & $0-3$ years & 7 & $\bullet$ & - \\
\hline & $\begin{array}{l}\text { Home-based, non-relative day } \\
\text { care (not child's own home) }\end{array}$ & $0-3$ years & 7 & • & - \\
\hline \multirow{4}{*}{ PPE } & Center-based & $\begin{array}{l}3 \text { to not-yet- } \\
\text { in-kindergarten }\end{array}$ & 5 & $\bullet$ & - \\
\hline & $\begin{array}{l}\text { Home-based, non-relative } \\
\text { (not child's own home) }\end{array}$ & $\begin{array}{l}3 \text { to not-yet- } \\
\text { in-kindergarten }\end{array}$ & 7 & & - \\
\hline & Kindergarten, public school & * & 6 & $\bullet$ & \\
\hline & Kindergarten, private school & * & 6 & & $\bullet$ \\
\hline
\end{tabular}

Key:

- Funding type exists.

Explanatory notes:

* In the majority of states, kindergarten begins the last week of August or the first week of September and to enroll children must be five years of age by approximately August 31 or September 1 of the school year (this date varies by state: see http://nces.ed.gov/programs/statereform/tab5_3.asp).

The typical length of day in this table is not reflective of operating hours. The typical length of day is the number of hours the average child in the setting type attends. For center-based ECE and home-based ECE the typical length of day is calculated by dividing the number of hours per week children attend by the number of days per week they attend. For kindergarten, typical daily length of provision is full-day kindergarten.

Approximately $77 \%$ of kindergarteners attend full-day programs and $23 \%$ attend part-day programs.

\section{Sources:}

US Department of Education, National Center for Education Statistics, Early Childhood Program Participation Survey of the 2012 National Household Education Surveys Program (ECPP-NHES) (US Department of Education, 2012a), US Department of Education, National Center for Education Statistics, Parent and Family Involvement in Education Survey of the 2012 National Household Education Surveys Program (PFI-NHES) (US Department of Education, 2012b). 
Center-based ECE includes day care centers, preschools, or prekindergarten programs, not private homes. Center-based ECE often includes Head Start, a federally-funded ECE program targeted at low-income families.

Family-based ECE refers to the early care and education of several children (other than the provider's own) in the caregiver's own home. This includes home-based providers or neighbors, but not day care centers, preschools, or care provided by a child's relative in the home.

Both center-based ECE and family-based ECE serve children from birth through to not-yet-in-kindergarten. Therefore, in this report, participation in these broad types of ECE is reported for both the ECED and the PPE age groupings.

In the United States, the year prior to ISCED Level 1 is kindergarten. Kindergarten is regulated by individual states. In 45 states and DC, school districts are required to provide kindergarten programs, with the other five states leaving it up to local school districts to decide whether or not to offer kindergarten; 11 states plus DC require school districts to offer full-day kindergarten, and, in 15 states and DC, kindergarten attendance is mandatory.

The majority of ECE settings that serve children from birth through age five but notyet-enrolled-in-kindergarten are private fee-based services; there are also some notable state-funded or federally-funded programs.

- State-funded preschool: 41 states and DC offer state-funded preschool programs that serve children the year prior to kindergarten (Barnett Carolan, Squires, Clarke Brown, \& Horowitz, 2015) with two additional states beginning programs in the 2015-2016 school year. However, in 2015, the majority of these programs were not universally available to all age eligible children within the state.

- Head Start: Head Start and Early Head Start promotes the school readiness of young children from low-income families through federal grants to organizations in their local communities. Head Start programs support the mental, social, and emotional development and education of children ages three, four and five but not yet enrolled in kindergarten. Early Head Start programs are available to the family until the child turns three years old and is ready to transition into Head Start or another prekindergarten program. Three- and four-year-olds made up over $80 \%$ of the children served by Head Start last year.

- Title I: Title I is a federal grant program designed to give educational assistance to students living in areas of high poverty. The Title I program originated in 1965, when Congress passed the Elementary and Secondary Education Act, and was reauthorized in 2001 with the passage of the No Child Left Behind Act (US Public Law 107-110). Over 600, 000 children are also served through preschool programs funded through federal Title I allocations to school districts and schools.

- Individuals with Disabilities Act (IDEA): The Individuals with Disabilities Education Act (IDEA) ensures that all children with disabilities are entitled to a free appropriate public education to meet their unique needs and prepare them for further education, employment, and independent living. IDEA provides federal grants to states and guidelines concerning the funding and services to children from birth to two years of age and from age three to age twenty-one. For example, IDEA states that every family is entitled to appropriate and timely identification and intervention services for children aged birth to two years. For children aged three to twenty-one years, every child is entitled to a free and appropriate public education. 
- Child Care and Development Block Grant (CCDBG): The Child Care and Development Block Grant (CCDBG) is a federal grant to states that help low-income families, families receiving public assistance, and those families transitioning from public assistance in obtaining early education and care.

In summary, there are a wide range of program types within the United States, often very broadly categorized as either center- or home-based, delivered in a variety of settings with both public and private funding. In addition, ISCED Level 0 within the United States includes kindergarten, which is often thought of as the first year of primary school. Even though kindergarten attendance is not compulsory throughout the United States, the majority of children attend.

Examination of setting types within the eight study countries reveals that, in all countries, there is a wide variety of setting types delivering services to under-threes (ECED) and for children aged three up to primary school age (PPE). Some countries have a greater variety of settings than others, and the number also varies with the age of the child. Settings in all countries are generally focused on a particular age group of children, usually birth to three-year-olds (ECED) or three to primary school age children (PPE), but Denmark and Estonia have fully integrated settings that cater for children from birth to primary school age.

Funding for ECE settings is equally complex. In Denmark and Estonia, all ECED and PPE settings are fully publicly funded, but, in Chile, the Czech Republic, Italy, Poland, the Russian Federation and the United States, settings can be fully publicly funded, fully privately funded, or receive a mixture of public and private funding. All of the study countries had ECED and PPE settings that offered a range of daily schedule options, from short sessions to extended day services ( $>10$ hours), with the Russian Federation also offering 24-hour services in one case.

\section{Summary Finding 7}

In all study countries, there are various setting types or forms of provision delivering ECE services to children under three years old (ECED) and from three years up to primary school age (PPE). These include home-based and center-based services and may be called crèches, kindergartens, nursery schools, nursery or kindergarten classes in primary schools, kids clubs, preschools, day care centers, and integrated centers. Some countries have a greater variety of setting types than others, and the number of setting types also tends to reduce with the age of the child. The variety in types of provision in the study countries exemplifies the complexity and diversity in the delivery of ECE services during ISCED Level 0.

\section{Summary Finding 8}

Settings in the study countries are mostly focused on a particular age group of children, usually birth to three years old (ECED) or three to primary school age children (PPE), but Denmark and Estonia have fully integrated settings that cater for children from birth to primary school age. Funding for ECE settings is complex, with some countries fully funding ECE services but, in the majority of countries, settings can be fully publicly funded, fully privately funded, or receive a mixture of public and private funding. 


\section{Summary Finding 9}

Funding for ECE settings is complex. In Denmark and Estonia, all ECED and PPE settings are fully publicly funded, but in Chile, the Czech Republic, Italy, Poland, the Russian Federation and the United States settings can be fully publicly funded, fully privately funded, or receive a mixture of public and private funding.

\section{Summary Finding 10}

All of the study countries have ECE settings that offer a range of daily schedule options, from short sessions to extended day services (over 10 hours), with the Russian Federation also offering 24-hour services in one type of setting. Often, parents may also have to use more than one setting if they require 10 or more hours. In the United States, for example, a child may attend preschool at a primary center in the morning, a different program in the afternoon, and home-based child care in the late afternoon to evening.

\section{Target Populations}

For certain groups, participation in ECE services has been enhanced by policy initiatives in some countries, and strategies developed to encourage certain settings to target their services to identified populations (European Commission/EACEA/Eurydice/Eurostat, 2014; OECD, 2013). These target populations may include families with low income, children with special educational needs, minority ethnicity families, or families where the home language is different from the school language. The Czech Republic, Italy and Poland emphasize an inclusive approach in all their settings; for example, children with special needs or disability are integrated as much as possible with other children. These countries have few special kindergartens for children with disabilities.

However, Chile, Denmark, Estonia, the Russian Federation and the United States do target certain populations in some of their settings. The most common target populations are low-income families, and children with special needs and disability. For example, Chile has developed a targeting strategy for low-income families in some of its settings through the national program, "Chile Grows With You," while, in other settings, a more heterogeneous population is encouraged. Denmark has universal access to its settings, but low-income families, families with children with special needs, and families where the home language is not Danish, including ethnic minority groups, are especially encouraged to attend ECE services. In some cases, communities can force parents to send their children to a setting. Estonia targets low-income families, children with special needs and disability, minority ethnic groups, and children whose home language is different. The Russian Federation targets groups with special needs and disabilities, with some settings specifically focused on children with special needs, disability or health issues. The United States targets low-income families, particularly in its publicly-funded ECE services, through programs such as Child Care Development Block Grants (CCDBG), Head Start and Early Head Start, as well as some state preschool programs. 


\section{Summary Finding 11}

There is a mixed approach to targeting certain populations to enhance their participation in ECE services, with some countries avoiding a targeting approach, and adopting a universal and integrated approach (Czech Republic, Italy and Poland) and others embracing targeting as a useful strategy to increase the integration and inclusion of certain groups, particularly children from low-income families, and children with special needs or disability (Chile, Denmark, Estonia, the Russian Federation and the United States).

\section{Setting Enrollment Rates}

Providing access to ECE settings does not necessarily result in achieving full enrollment, as at different ages and in different family circumstances, variation in need and demand for ECE will necessarily occur (Table 9).

Table 9: Enrollment rates for children aged from 0-3 years (ECED) and from 3 years to the start of primary schooling (PPE) at different ages

\begin{tabular}{|c|c|c|c|c|c|c|c|}
\hline \multirow[b]{2}{*}{ Country } & \multicolumn{7}{|c|}{ Enrollment rates as a \% for age groups 0-7 } \\
\hline & 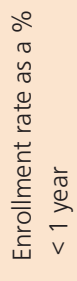 & 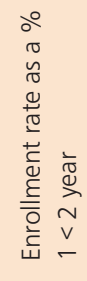 & 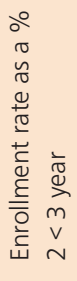 & 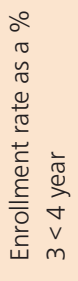 & 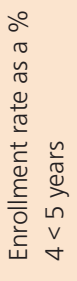 & 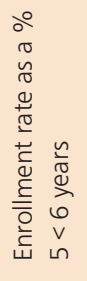 & 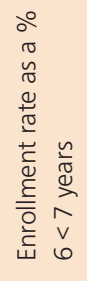 \\
\hline Chile $^{a}$ & 4.0 & 18.8 & 32.7 & 55.6 & 81.4 & $95.9^{*}$ & $\mathrm{n} / \mathrm{a}$ \\
\hline Czech Republic ${ }^{b}$ & \multicolumn{3}{|c|}{30.4} & 77.3 & 87.4 & $90.5^{*}$ & 17.1 \\
\hline Denmark ${ }^{c}$ & 17.5 & 86.1 & 94.1 & \multicolumn{2}{|c|}{97.0} & - & - \\
\hline Estonia & - & 26.2 & 72.4 & 88.9 & 93.0 & 94.0 & $100.0 *$ \\
\hline Italy & - & - & - & 92.0 & 96.1 & $88.3^{*}$ & 1.3 \\
\hline Poland & - & - & - & 57.0 & 71.0 & 94.0 & $79.0 *$ \\
\hline Russian Federation $^{d}$ & \multicolumn{3}{|c|}{11.2} & \multicolumn{4}{|c|}{77.4} \\
\hline United States & 17.2 & 26.2 & 32.1 & 47.9 & 66.4 & 86.0 * & 33.0 \\
\hline
\end{tabular}

Key:

- No data provided.

* The final year of ISCED 0.

\section{Explanatory notes:}

It should be noted that enrollment rates given in the table are reflective of the settings defined within the study scope, which may not be exhaustive. For example, a setting not included might be home-based care provided by a relative, or care provided in the child's home.

\section{Country specific notes:}

a The evidence for Chile is taken from the National Socioeconomic Survey (CASEN) (Ministry of Social Development, 2011) The percentages represent the total of children attending, including special education.

b The Czech Republic were able to provide enrollment figures for children younger than three years, but these were not broken down into individual age bands.

c Denmark was able to provide figures based on the age group three to five years as a whole, and could not break this down further.

$d$ The Russian Federation was able to provide figures based on the age groups birth to three, and three to seven, and could not break down the figures further. 
The evidence suggests that there is a paucity of data on enrollment rates in ECE for children under the age of three (ECED) compared to that available for children over the age of three years (Table 9). For example, in Italy, it is reported that, for ECED, enrollment data differentiated by age are unavailable, and where data have been provided the figures should be treated with caution and used as a "best estimate." Poland also reported that for children aged under three years old the statistics are less reliable. The Czech Republic, Denmark and the Russian Federation were able to provide composite data for a broader age group, but not for individual year groups.

Whilst acknowledging these data limitations, where evidence is reported, for Chile, Denmark, the Russian Federation and the United States, this reveals that, for underthrees, enrollment levels increase with the age of the child. At PPE level, a similar pattern of rising enrollment levels up to the age of six years is evident in Chile, the Czech Republic, Estonia, Poland and the United States. In Italy, enrollment drops slightly for five- to six-year-olds (which may be due to early pre-primary enrollment). In Denmark and the Russian Federation, there are only composite data for this period, so it is difficult to determine annual enrollment. However, in all the study countries, by the age of six years enrollment in PPE is high, with all countries, except the Russian Federation and Poland, having enrollment levels in the final year of ISCED Level 0 above $86 \%$. Between the age of six and seven years, the information indicates that enrollment in ECE can vary significantly from the previous year, and in the Czech Republic, Italy, Poland and the United States it decreases, which suggests that transition of the child to primary schooling and out of the ECE system may be underway.

\section{Summary Finding 12}

Enrollment levels to ECE services appear to increase in line with the age of the child, with high levels of enrollment (above 86\%) in all the study countries (where data are available) in the final year of ISCED Level 0; some countries approach $100 \%$ enrollment.

\section{Setting Funding Strategies}

Funding strategies for ECE settings can be divided into two basic approaches: supply-side and demand-side funding. Supply-side funding refers to funding that is made available by the state or other public body to a supplier or provider of ECE to increase or improve their provision. Supply-side funds, for example, may take the form of direct grants for building (capital grants), resources (resource grants), and grants to supplement staff wages (staff salary subsidy) or to increase quality through staff training. Sometimes government bodies will fund private providers by paying a subsidy based on places provided. Such grants are termed, "funded places subsidies." Demand-side funding refers to funding from the state or other body being made available directly to parents, so parents can choose where to place their children. It enables parents to be consumers and to make choices. Such funding may take the form of parent grants or reduced fees, parent vouchers or credit authorization for ECE child care, tax relief or reduction, or general child or family allowances where parents receive weekly or monthly funds from the state to support their child's upbringing. 
Table 10: Supply-side funding from central funds for children aged from 0-3 (ECED) and children aged from 3 to the start of primary schooling (PPE)

\begin{tabular}{|c|c|c|c|c|c|}
\hline \multirow[b]{2}{*}{ Country } & \multirow[b]{2}{*}{ Level } & \multicolumn{4}{|c|}{ Types of supply-side funding } \\
\hline & & $\begin{array}{l}\text { Funded places } \\
\text { subsidy }\end{array}$ & $\begin{array}{l}\text { Staff salary } \\
\text { subsidy }\end{array}$ & Capital grants & Resource grants \\
\hline \multirow[t]{2}{*}{ Chile } & ECED & $\bullet$ & $\bullet$ & $\bullet$ & $\bullet$ \\
\hline & PPE & $\bullet$ & $\bullet$ & $\bullet$ & $\bullet$ \\
\hline \multirow[t]{2}{*}{ Czech Republic } & ECED & $\mathrm{n} / \mathrm{a}$ & $\mathrm{n} / \mathrm{a}$ & $\mathrm{n} / \mathrm{a}$ & $\mathrm{n} / \mathrm{a}$ \\
\hline & PPE & $\bullet$ & $\bullet$ & $\bullet$ & $\bullet$ \\
\hline \multirow[t]{2}{*}{ Denmark ${ }^{a}$} & ECED & $\bullet$ & $\bullet$ & $\bullet$ & $\bullet$ \\
\hline & PPE & $\bullet$ & $\bullet$ & $\bullet$ & $\bullet$ \\
\hline \multirow[t]{2}{*}{ Estonia } & ECED & $\bullet$ & $\bullet$ & $\bullet$ & $\bullet$ \\
\hline & PPE & $\bullet$ & $\bullet$ & $\bullet$ & $\bullet$ \\
\hline \multirow[t]{2}{*}{ Italy b } & ECED & $\bullet$ & $\bullet$ & $\bullet$ & $\bullet$ \\
\hline & PPE & $\bullet$ & $\bullet$ & $\bullet$ & $\bullet$ \\
\hline \multirow[t]{2}{*}{ Poland } & ECED & & $\bullet$ & $\bullet$ & $\bullet$ \\
\hline & PPE & & $\bullet$ & $\bullet$ & \\
\hline \multirow{2}{*}{$\begin{array}{l}\text { Russian } \\
\text { Federation }\end{array}$} & ECED & & $\bullet$ & $\bullet$ & $\bullet$ \\
\hline & PPE & & $\bullet$ & $\bullet$ & $\bullet$ \\
\hline \multirow[t]{2}{*}{ United States } & ECED & $\bullet$ & $\bullet$ & & $\bullet$ \\
\hline & PPE & - & & & - \\
\hline
\end{tabular}

Key:

- Supply-side funding is available.

n/a Funding from central funds does not exist.

Country specific notes:

a In Denmark, ECED and PPE are paid for through taxation, regulated by national law and locally organized. The funding is not specified, but is used for all aspects of service delivery.

b In Italy, for ECED central supply-side funding is available, but it is not specified how it is spent. The NRC reported that it is impossible to determine which combination of subsidies has been used. For PPE, the central authority (Ministry of Education) transfers $80 \%$ of resources mainly for staff salary to all schools, including preschools, but excluding municipally-run institutions. The remainder $20 \%$ is composed of capital expenditure and current expenditure. Capital investments include major building upgrading and building of new schools; current expenditure is used for service delivery (goods and services such as teaching materials, management expenditure, small-scale maintenance and cleaning). Financial resources coming from the state for the administrative running of schools are provided without any constraints on their priority destination, and schools have full autonomy to use these resources for their own institutional aims. Source: Personal communication from the Ministry of Education to the NRC, 7 October 2015.

For settings that serve children under the age of three, supply-side funding is available in seven of the eight study countries, namely Denmark, Chile, Estonia, Italy, Poland, the Russian Federation, and the United States (Table 10). Supply-side funding is not used in the Czech Republic to support services for under-three-year-olds. Chile, Estonia, and the United States use supply-side funding to provide a funded places subsidy. In Chile, Estonia, Poland, the Russian Federation and the United States there is a staff salary subsidy. Chile, Estonia, Poland and the Russian Federation provide funds for capital grants to settings, and Chile, Estonia, Poland, the Russian Federation and the United States provide resource grants to settings. Italy and Denmark have public funding for services for under-threes, but do not specify how this is spent; thus funding can be used for all aspects of service delivery. 
For settings designed to serve children from three years to primary school, supply-side funding is available in all eight study countries. In Chile, the Czech Republic, Estonia and the United States, such funding provides a funded place subsidy. In Chile, the Czech Republic, Estonia, Poland and the Russian Federation, it provides a staff salary subsidy. Chile, the Czech Republic, Estonia, Poland, and the Russian Federation fund capital grants to settings, and Chile, the Czech Republic, Estonia, the Russian Federation and the United States also provide resource grants to settings. In Denmark, there is public funding for services for children from three to primary school age, but it is not specified how this is spent, and funds can be used for all aspects of service delivery.

The evidence indicates that supply-side funding is used extensively in the study countries as a key element in the financing of ECED and PPE settings. For example, in Chile, JUNJI and Integra ECED settings receive public funding through a legal agreement, in addition to public funds made available through other programs such as food programs, infrastructure investment, educational resources and curricular development. Public and private nursery schools for children over three years old also have nationally agreed funding amounts per child, which can amount to $100 \%$ of the costs. In Italy, capital grants from the government are provided in full or in part by the local authority responsible for municipal PPE settings. This is used for new building and maintenance. In addition, all state preschools are funded by the Italian Ministry of Education to support staff and running costs. In Poland, a program enables counties to obtain capital grants from the state to create a crèche or sustain existing places in crèches. Independent settings also receive a subsidy for each of the children in the setting, which covers staff salaries and the upkeep of the building. Public preschools are financed by the state. In the Russian Federation, public and private ECED and PPE settings receive specific grants from the government for staff salaries, the purchase of materials and building maintenance. In the United States, supply-side funding is achieved through such programs as Head Start, Child Development Block Grants, the Individuals with Disabilities Education Act and, increasingly, through state preschools and prekindergarten programs.

For settings serving children under the age of three, demand-side funding is available in all the study countries except the Czech Republic (Table 11). It is not used in the Czech Republic to support services for under-three-year-olds. In Estonia and the United States, this funding provides tax credits or tax relief for parents of under-threeyear-olds who use ECED services. In Chile, Italy and the United States, demand-side funding provides vouchers for parents to purchase ECED services. Denmark, Estonia, Italy, Poland, the Russian Federation and the United States subsidize the fees for ECED services for parents. In Chile, Estonia, the Russian Federation and the United States, such funding also provides resource grants to settings. In Estonia, there are family allowances for parents.

For settings serving children from three years to primary school, demand-side funding is used in all of the eight study countries. In the Czech Republic, Estonia, and the United States, this funding provides tax credits or relief for parents who use PPE services. Chile and the United States provide vouchers for parents to purchase PPE services. Denmark, Estonia, Poland, the Russian Federation and the United States fund the reduction of fees for PPE services for parents. In Czech Republic and Estonia, demand-side funding also provides family allowances to parents. 
Table 11: Demand-side funding for children aged from 0-3 (ECED) and children aged from 3 to the start of primary schooling (PPE)

\begin{tabular}{|c|c|c|c|c|c|}
\hline \multirow[b]{2}{*}{ Country } & \multirow[b]{2}{*}{ Level } & \multicolumn{4}{|c|}{ Types of demand-side funding } \\
\hline & & Tax credits/relief & Vouchers & Reduced fees & Family allowances \\
\hline \multirow[t]{2}{*}{ Chile } & ECED & & $\bullet$ & & \\
\hline & PPE & & $\bullet$ & & \\
\hline \multirow[t]{2}{*}{ Czech Republic } & ECED & $\mathrm{n} / \mathrm{a}$ & $\mathrm{n} / \mathrm{a}$ & $\mathrm{n} / \mathrm{a}$ & $\mathrm{n} / \mathrm{a}$ \\
\hline & PPE & $\bullet$ & & & $\bullet$ \\
\hline \multirow[t]{2}{*}{ Denmark } & ECED & & & $\bullet$ & \\
\hline & PPE & & & $\bullet$ & \\
\hline \multirow[t]{2}{*}{ Estonia } & ECED & $\bullet$ & & $\bullet$ & $\bullet$ \\
\hline & PPE & $\bullet$ & & $\bullet$ & $\bullet$ \\
\hline \multirow[t]{2}{*}{ Italy } & ECED & $\bullet$ & $\bullet$ & $\bullet$ & \\
\hline & PPE & & & & \\
\hline \multirow[t]{2}{*}{ Poland } & ECED & & & $\bullet$ & \\
\hline & PPE & & & $\bullet$ & \\
\hline \multirow{2}{*}{$\begin{array}{l}\text { Russian } \\
\text { Federation }\end{array}$} & ECED & & & $\bullet$ & \\
\hline & PPE & & & $\bullet$ & \\
\hline \multirow[t]{2}{*}{ United States } & ECED & $\bullet$ & $\bullet$ & $\bullet$ & \\
\hline & PPE & $\bullet$ & $\bullet$ & $\bullet$ & \\
\hline
\end{tabular}

Key:

- Demand-side funding is available.

$\mathrm{n} / \mathrm{a}$ Demand-side funding does not exist.

Demand-side funding is also used extensively in the study countries as a key element in the financing of ECED and PPE settings; however, in Italian PPE settings demandside funding is very limited due to the free nature of service provision. In Chile, all public ECE settings receive demand-side funding through a voucher system that is not given directly to parents but "follows the child." This means that the fund is transferred directly to the setting, but gives parents the option to choose the ECE provision they prefer. In Denmark, low-income families and children with special needs or who do not speak the national language pay reduced fees. In the Czech Republic, family allowances and tax benefits are provided to parents. In Poland, all PPE fees are capped for the first five hours of care daily. In the Russian Federation, parents get compensation for the average amount of parental fees for ECED services, not less than $20 \%$ for the first child, $50 \%$ for the second child, and $70 \%$ for the third and subsequent children. In the United States, there are tax deductions related to the number of dependents in the household. They also have itemized tax deductions related to the expense of ECE and before and after school care. 


\section{Summary Finding 13}

Supply-side and demand-side funding are both used extensively in the study countries as key elements in the financing of ECE settings at both ECED and PPE level. Supply-side funding is used in a variety of ways, including subsidizing funded places, subsidizing staff salaries, and providing capital and resource grants to settings. Methods of demand-side funding include: providing tax credits or relief, offering vouchers to parents, reduced fees, and family allowance payments. In those countries where there is largely publicly-funded ECE provision (Denmark, Estonia and Italy), supply-side funding predominates.

\section{System Transitions}

In many countries, the relationship between ECE (ISCED Level 0) and the school system (ISCED Level 1 onwards) has not been strong and coherent (OECD, 2001). Starting Strong (OECD, 2001) proposed an equal partnership between early childhood education and care systems, and suggested that the education system should be developed to include provision from birth. It was felt that partnership with the education system would bring together the diverse perspectives and methods of both ECE and schools, focusing on the strengths of both, and also benefit children's developmental progress as they moved through the care and education systems.

One of the recommended ways to secure smooth transitions between phases within ECE settings or from the ECE setting to school is for different service providers to communicate and cooperate with one another (OECD, 2012b). Stephen (2006) also outlined a number of ways that a setting may work with primary schools to help the transition, such as visits to familiarize children with the building, its staff and pupils, and induction meetings for parents. Developing effective ways of passing information from settings to schools may also improve transitions. Some countries' curricula have been developed to form a bridge between the ECE setting and primary school, for example the South Australian Curriculum Standards and Accountability Framework (Government of South Australia, 2009). Transition support and guidance for parents and children at key points in the system at ISCED Level 0 and ISCED Level 1 can also smooth the passage from one part of the system to another (Stephen, 2006).

Given the benefits of effective system transitions for children, parents, providers and policymakers, as outlined, the ECES explored the existence of national guidance to support transitions at key points in the ECE system in the eight study countries.

Of the eight study countries, five indicated that they have national guidelines to support transition at key points in the ISCED Level 0 system (the Czech Republic, Denmark, Estonia, the Russian Federation and the United States) and three countries reported that no national transition guidelines exist (Chile, Italy and Poland). The Czech Republic has guidance available to support transition practice from home to center-based ECE, which is set by the Framework Educational Program (Smolíková et al., 2004, p. 44), and which includes cooperation with parents during this transfer. Denmark has a national law (Dagtilbudsloven, Chapter $2 \$ 7,5$ ) that states that pedagogues must help children in transitions from one setting to another at all transition points, though there are no special guidelines for settings or parents. Estonia has guidelines for parents, children and practitioners at three key points: from home to center-based ECED; from ECED 
to PPE; and from ISCED Level 0 (PPE) to ISCED Level 1. The Russian Federation has guidance for parents, children and practitioners at three key points: from home to center-based ECED; from ECED to PPE; and from ISCED Level 0 to ISCED Level 1. For example, when a child transfers from home to center-based ECE, there are guidelines that encourage a gradual induction of the child, leaving the child for a few hours the first time, and then gradually increasing the length of stay during the first month. Transition from ECED to PPE is supported at a program or curriculum level. The United States has guidance for parents, children and practitioners to support transition from one setting in the system to the next at several key points, such as: from home to centerbased ECE, from ECED to PPE; from PPE into kindergarten; and from kindergarten to ISCED Level 1. For example, on transition from home to center-based ECE Head Start establishes guidelines for its programs that address the development of children aged three to five years. It is reported that many states adopt a version of these standards to guide both parents and settings on the transition from ECED to PPE, and from PPE to ISCED Level 1.

However, the absence of national guidelines does not mean that support for transition is not available. Italy reported that national curriculum guidelines for PPE mention the transition to primary school, and that there is evidence (national monitoring of 2012) that $95 \%$ of PPE schools have some practices in place concerning the transition of children from pre-primary to primary school. Among these practices, the most cited are: a specific commission covering the two school levels, planning of common activities, meetings for the exchange of information and for joint planning between teachers of the two school levels, and meetings for reciprocal acquaintance of teachers. In Poland too, although there are no national guidelines or programs, there is an awareness of this issue and there are grassroots initiatives in this area of practice.

\section{Summary Finding 14}

In the study countries, there is an awareness of the importance of offering support in transition for parents, children and practitioners at key points in the ECE system and through to ISCED Level 1, and encouragement at national or subnational level for the incorporation of transition strategies within ECE practice in the majority of the study countries, supported by national guidelines in the Czech Republic, Denmark, Estonia, the Russian Federation and the United States.

Open Access This chapter is distributed under the terms of the Creative Commons AttributionNonCommercial 4.0 International License (http://creativecommons.org/licenses/by-nc/4.0/), which permits any noncommercial use, duplication, adaptation, distribution and reproduction in any medium or format, as long as you give appropriate credit to the original author(s) and the source, provide a link to the Creative Commons license and indicate if changes were made.

The images or other third party material in this chapter are included in the works Creative Commons license, unless indicated otherwise in the credit line; if such material is not included in the works Creative Commons license and the respective action is not permitted by statutory regulation, users will need to obtain permission from the license holder to duplicate, adapt or reproduce the material. 
CHAPTER 6:

\section{Participation and Enrollment}

This chapter of the report presents information about children's participation in ECE services in the eight study countries. These data inform readers about the levels of child participation in ECE for subgroups of the population and at different ages, prioritizing or targeting strategies for setting enrollment, how settings reflect diversity and cultural difference, the coverage and availability of provision, the cost to parents for participation and the use of early intervention programs targeted at subgroups of the population. Within and between country similarities and variations in enrollment and participation are highlighted.

As mentioned previously (page 22), the benefits to children of attending ECE settings have been clearly demonstrated, including those that relate to addressing social inequalities (Corak et al., 2012; Karoly et al., 2005; Pascal, \& Bertram, 2012; Sylva et al., 2004, 2008). This evidence underlines the importance of children from less advantaged backgrounds participating in high quality ECE services. Many countries are developing policies to increase and widen the participation of children in ECE services, particularly in the PPE phase. Yet, despite these positive signs, there remains evidence (Corak et al., 2012; OECD, 2012b; Pascal, \& Bertram, 2012) that achieving full participation for certain populations is challenging, for example for children with special needs or disability, children with certain health conditions, children from lowincome households and children from some ethnic minorities. There is evidence that the barriers to participation, (such as costs, cultural insensitivity, limited physical access, and lack of appropriately trained staff) for these groups contribute substantially to the inequalities in educational outcomes. Many young children do not have the benefit of high quality, enriching early education experiences, which, through early intervention, can do much to counter disadvantage, disability, developmental delay and lack of social mobility in young children (Corak et al., 2012; Karoly et al., 2005). It has also been suggested that participation in ECE can help children to be better prepared for school, thereby improving their ability to succeed (Hart, \& Risely, 1995; Heckman, 2000; Pascal, \& Bertram, 2012).

Evidence (OECD 2012b) indicates that, in those countries where publicly-funded free ECE programs exist, they enroll high numbers of the eligible age group across socioeconomic levels. Where early education is not a free and universal entitlement, market pricing generally determines which parents can afford to send their children and where they can send them. It is also often the case that families of children with special needs find it more difficult to access private and voluntary sector provision due to the costs involved in supporting these children (OECD, 2006). There is increasing international evidence (Corak et al., 2012) that, in many countries, children from lowincome families continue to be less likely to attend high quality early education and care programs, even though they benefit more than their more advantaged peers. Estimates indicate that if all children from low-income families were to be enrolled in high quality early education programs, such reforms could close the gap in achievement by as much as $20-50 \%$, revealing what a powerful driver early education can be in countering socioeconomic disadvantage (Corak et al., 2012; Pascal, \& Bertram, 2012).

Given this wider evidential context, the ECES explored the enrollment levels of children in ECE from different populations, how enrollment levels are enhanced, and systemic factors that might affect this participation in the eight study countries. 


\section{Levels of Participation in ECE Programs for Children from Subgroups of the Overall Population}

To enhance participation in ECE programs, countries can provide legal entitlements to enable all children to access affordable, high-quality ECE. In particular, many countries have started to offer free universal ECE services to certain age groups, usually one or two years before the start of compulsory schooling; this does seem to result in high levels of participation (EIU, 2012; OECD, 2012b). Further research (OECD, 2012b) suggests that even with this entitlement children from low-income families, ethnic minorities (including immigrants), and those with disabilities or special needs, continue to have lower levels of participation than other groups. The evidence also reveals that the enrollment of children with these characteristics in ECE services is often dependent on the policy decisions made in each country. For example, those countries in the study providing subsidized, publically-funded ECE have a larger proportion of the eligible age cohort enrolled. ECE services, especially those that are not publically funded, often have lower enrollment of children coming from these subgroup populations (EIU, 2012; OECD, 2012b; Pascal, \& Bertram, 2012). This has significant implications for the educational outcomes of children with these characteristics.

Building on the evidence presented in Chapter 5 (Table 9) on total enrollment levels in ECE services at different ages, the ECES policy data explored the levels of enrollment in ECE services for subgroups of children in the overall population at different ages in the eight study countries. In particular, the study collected information about participation levels of children from low-income families, children with special needs or disability, children from minority ethnic groups and children whose home language is other than the national language (Table 12).

Data on enrollment rates in ECE broken down for children with certain characteristics is often not collected or is less easily available (Table 12). This is a significant data gap for policy development purposes and one which should be addressed if stated country goals for ECE are to be achieved. The Czech Republic, Italy, Poland and the Russian Federation all reported that data was not collected in this way or that this data was hard to access. Four countries were able to supply data: Chile (data on children from lowincome families only), Denmark, Estonia and the United States.

\section{Children from Low-Income Families}

The enrollment data on children from low-income families reveal that the proportion of children falling into this group varies significantly across the study countries, from $75 \%$ in Chile, 24\% in the United States, 15\% in Estonia, to 6\% in Denmark. In Estonia and Denmark, where the proportion of these children in the total population is relatively small, and there is publically-funded universal ECE, enrollment levels of these children are high: in Estonia there is 100\% at both ECED and PPE levels, and, in Denmark, 95\% enrollment for ECED and $97 \%$ for PPE. In Chile, where approximately $75 \%$ of the population is defined as low income, and there is a mix of publicly-funded and private ECE, the enrollment in ECE for ECED-aged children is 12\% and PPE aged children is $49 \%$. Within the United States, approximately $24 \%$ of PPE and ECED aged children live in poverty, with 13\% of low-income ECED aged children enrolled in ECE and 59\% of low-income PPE aged children enrolled in ECE. It is also interesting to note that the evidence presented in the table indicates that in Estonia and Denmark the enrollment level of children from low-income families exceeds the enrollment level of children in 
Table 12: Child characteristics and enrollment levels of children aged from 0-3 years (ECED) and children aged from 3 years to the start of primary schooling (PPE)

\begin{tabular}{|c|c|c|c|c|c|c|c|c|c|c|}
\hline & & \multicolumn{9}{|c|}{ Enrollment of children in ECE services } \\
\hline Country & Level & 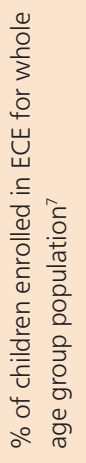 & 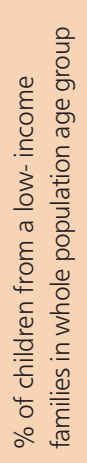 & 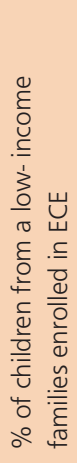 & 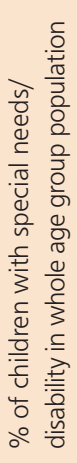 & 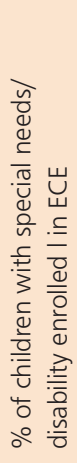 & 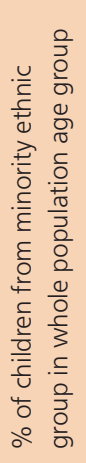 & 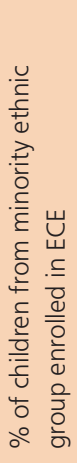 & 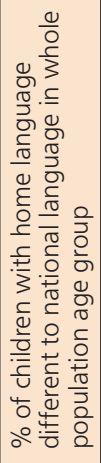 & 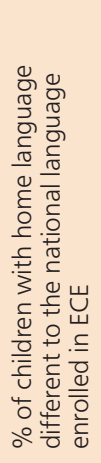 \\
\hline \multirow[t]{2}{*}{ Chile $^{a}$} & ECED & 19 & 75 & 12 & - & - & - & - & - & - \\
\hline & PPE & 67 & 75 & 49 & - & - & - & - & - & - \\
\hline \multirow[t]{2}{*}{ Denmark $^{b}$} & ECED & 66 & 6 & 95 & 5 & 91 & 1 & - & - & - \\
\hline & PPE & 94 & 6 & 97 & 5 & 97 & 1 & 97 & - & - \\
\hline \multirow[t]{2}{*}{ Estonia } & ECED & 24 & 15 & 100 & 11 & 100 & 17 & 100 & 17 & 100 \\
\hline & PPE & 90 & 15 & 100 & 11 & 100 & 17 & 100 & 17 & 100 \\
\hline \multirow[t]{2}{*}{ United States ${ }^{c, d}$} & ECED & 43 & 24 & 13 & 1 & 23 & 49 & 21 & 12 & 13 \\
\hline & PPE ${ }^{e}$ & 61 & 24 & 59 & 5 & 65 & 51 & 61 & 9 & 52 \\
\hline
\end{tabular}

Key:

- No data available.

Explanatory notes:

The Czech Republic, Italy, Poland and the Russian Federation were unable to submit data. NRCs in the Czech Republic, Italy and the Russian Federation pointed out that, as they have universal access to free services (for Italy, only in PPE), they do not collect data for specific child populations, but only on the total number of children enrolled in each age group. No data are available for Italian ECED on the characteristics of users. It was reported that accessing this data was difficult in Poland.

\section{Country specific notes:}

a Chile reported that data are not collected for children with special needs/disability, children from minority ethnic groups and children whose home language is different than the national language.

b Denmark reported that there is universal entitlement to ECED and PPE.

c The United States used the following definitions:

- Low-income family: defined as a household in which household income in the 12 months prior to the survey date is at or below the poverty income threshold set by the US Census Bureau for a household of that size.

- Children with special needs/disability: children whose parents reported that a health or education professional determined the child had a condition and whose parents reported that the condition interferes with the child's ability to learn

- Minority ethnic group: These are children who are not reported as white or children reported as being in multiple racial/ethnic groups.

- Home language is different than the national language: Although the United States does not have an official national language, this characteristic was defined as children who mainly speak a language other than English at home. Children who speak both English and another language equally at home are not included. If a child does not yet speak, home language is determined by the parents' home language.

d In the United States, the \% figure for children with certain characteristics enrolled in ECE within the age group was calculated by dividing the number of children with these characteristics who are enrolled in ECE by the number of children with these characteristics in the age group: (number of children with these characteristics AND in ECE) / (number of children with these characteristics).

e For the United States, PPE includes enrollment in center-based ECE, licensed home-based ECE, and kindergarten. 
the total population. In Chile and the United States, the enrollment figure for children from low-income households is significantly lower than the enrollment level in the total population.

\section{Children with Special Needs or Disability}

The enrollment data on children with special needs or disability reveal that the proportion of children falling into this group is relatively low in all three study countries that submitted data: 5\% in Denmark, $11 \%$ in Estonia and 1-5\% in the United States. In Denmark and Estonia, where there is publicly-funded universal ECE, the enrollment level of these children is very high: in Denmark, 91\% for ECED and 97\% for PPE and, in Estonia, 100\% for both. In the United States, where there is targeted funded entitlement, the enrollment level is significantly lower, $23 \%$ of these children are enrolled in ECED services, $31 \%$ in PPE services up to the age of kindergarten, and 35\% in kindergarten. These data reveal the very different level of enrollment of children identified with special needs and disability across the study countries, with some countries achieving a higher level of participation than others.

\section{Children from a Minority Ethnic Group}

The enrollment data on children from a minority ethnic group reveal that the proportion of children falling into this group varies significantly in the three study countries that submitted data, $1 \%$ in Denmark, $11 \%$ in Estonia and $49-51 \%$ in the United States. In Denmark and Estonia, the enrollment level of these children is very high: in Denmark, 97\% for PPE and, in Estonia, 100\% for both. In the United States, where there is targeted funded entitlement, the enrollment level is significantly lower, $21 \%$ for ECED, 28\% for PPE up to the age of kindergarten, and 34\% for kindergarten.

\section{Children whose Home Language is Different than the National Language}

For the two countries that submitted enrollment data on children whose home language differs from the national or dominant language, the proportion of children falling into this group is 17\% in Estonia and 9-12\% in the United States. In Estonia, where there is publicly-funded universal ECE, the enrollment level of these children is very high: $100 \%$ for ECED and PPE.

\section{Summary Finding 15}

There is significant variation between the study countries as to the number of children in the population who are from low-income families, have special needs or disability, are from minority ethnic groups, and whose home language is different from the national language. In some countries, these subgroups can form a very sizable element of the population and, in others, a much smaller element, and this has implications for policy choices. Even given this variation, data from the four study countries that submitted evidence reveal differences in the level of enrollment of children from these subgroups, with the two reporting countries offering publiclyfunded universal ECE having a significantly higher level of participation of these subgroups than the two countries where there is targeted funded entitlement. 


\section{Prioritizing or Targeting Strategies for ECE Enrollment}

Recent evidence has shown (EIU, 2012; OECD, 2012b; Pascal \& Bertram, 2012) that many countries have a policy strategy of prioritizing or targeting their ECE programs towards children who are considered to be at risk of school failure, such as low-income families, children with special needs or disability, or children whose home language is other than the national language.

Prioritizing regulations in the study countries may give preferential enrollment to certain subgroups of children, including a focus on parental unemployment and low income, residential criteria (living in a specified local catchment area near the setting), special needs or disability, minority ethnic groups, language spoken at home not being the national language, and elder siblings being already enrolled in the school (Table 13).

Table 13: Existence and focus of prioritizing regulations for children aged 0-3 years (ECED) and children aged from 3 to the start of primary schooling (PPE)

\begin{tabular}{|c|c|c|c|c|c|c|c|c|}
\hline \multirow[b]{2}{*}{ Country $^{a}$} & \multirow[b]{2}{*}{ Level } & \multicolumn{7}{|c|}{ Focus of centrally prescribed prioritizing regulations for ECE places } \\
\hline & & 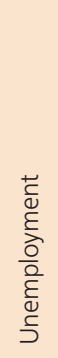 & 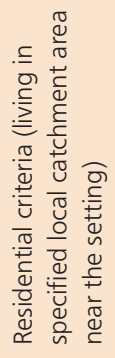 & 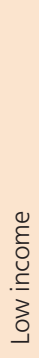 & 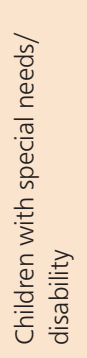 & 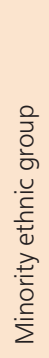 & 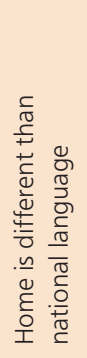 & 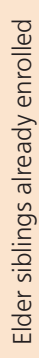 \\
\hline \multirow[t]{2}{*}{ Chile } & ECED & $\bullet$ & O & • & O & O & O & O \\
\hline & PPE & - & O & • & - & O & O & O \\
\hline \multirow[t]{2}{*}{ Czech Republic } & ECED & - & - & - & - & - & - & - \\
\hline & PPE & 0 & $\bullet$ & - & 0 & 0 & 0 & - \\
\hline \multirow[t]{2}{*}{ Poland b } & ECED & - & - & - & - & - & - & - \\
\hline & PPE & O & O & 0 & O & 0 & O & O \\
\hline \multirow{2}{*}{$\begin{array}{l}\text { Russian } \\
\text { Federation }\end{array}$} & ECED & O & O & O & - & 0 & O & O \\
\hline & PPE & O & 0 & 0 & $\bullet$ & 0 & 0 & O \\
\hline \multirow[t]{2}{*}{ United States } & ECED & O & O & $\bullet$ & - & $\bullet$ & O & $\mathrm{O}$ \\
\hline & PPE & 0 & - & $\bullet$ & $\bullet$ & & 0 & - \\
\hline
\end{tabular}

Key:

- Yes, centrally prescribed regulations with specific focus exist.

O No, centrally prescribed regulations with specific focus do not exist. No prioritizing regulations.

\section{Country specific notes:}

a In Denmark, Estonia and Italy, universal entitlement and access is in place (in Italy for PPE only) and so the NRCs reported no need for prioritizing regulations. In Italy the situation is mixed for ECED, since there are criteria for priority access to places in ECED but they are generally defined at the local level, in coherence with national purposes of ECED. Criteria usually include a combination of the following elements: parental occupation status; working mothers; low income; children with certified disability or special needs; children in social services; children with one parent only; children whose parents are both employed; families with multiple children; twins; and foreign children. Proximity to the setting could also be among these criteria. Similar criteria are set at the local level also for assigning free PPE places.

b In Poland, there are prioritizing regulations for children from three to start of primary school, but the law is currently under implementation so priority groups are not yet identified. 
Five of the eight study countries have national regulations for prioritizing enrollment in ECE services for certain population subgroups, with Chile, the Russian Federation and the United States using them for ECED, and Chile, the Czech Republic, Poland, the Russian Federation and the United States using them for PPE (Table 13). In other countries (Denmark, Estonia and Italy's PPE), it was reported that all children have universal access and so prioritizing policies are not required. The most common focus among the study countries for the prioritizing regulations are children whose parents have low income (used in Chile, the Czech Republic and the United States) and children with special needs or disability (used in Chile, the Russian Federation and the United States).

For example, in Chile, the national program, "Chile Grows With You" is the main program that allocates priority for ECED places to children from low-income families. This program guarantees a range of support services for children in vulnerable conditions, including free access to ECE. However, in order to have access to these services, the mother, father or guardian of the child must be working, searching for work, or studying. In Poland, new legislation has been passed which, when implemented, will prioritize children with disabilities, children with parents with disabilities, children from large families, children from foster families, and children raised by a single parent. In the Russian Federation, there are national regulations at both ECED and PPE level that give priority admission to children of large families, children with disabilities, children with disabled parents, children of single mothers, and children of soldiers, police officers, internal affairs officers and other Federation officers. In addition, there are regulations that give children "extraordinary" admission to ECE, such as children whose parents were exposed to radiation as result of the Chernobyl disaster, children who are deemed at risk, children of judges and prosecutors, and children with parents in the investigating authority of the Russian Federation. Regions can also establish additional admission priorities, such as minority ethnic group and residential criteria. In the United States, Head Start and Early Head Start target children from low-income families and reserve places for children with special needs or disabilities.

It should be noted that those study countries that do not have national prioritizing regulations may have local criteria to prioritize the allocation of ECE places. For example, in Italy, although there are general guidelines but no national prioritizing regulations, at a local level there are criteria that determine the priority of enrollment to ECE services for certain children. At the ECED level these criteria include parental occupation status or low income, children with certified disability, children being supported by social services, children of single parents, children where both parents are employed, children of ethnic minority groups, and children of families with multiple children. For children over the age of three years, PPE is universal, but again there are locally employed criteria to form waiting lists for available PPE places, giving preferential access to children with disabilities, difficult home circumstances or multiple disadvantages. In Poland, for children at ECED level, communes are responsible for setting the rules for allocating places to families and there are no central regulations. In Denmark and Estonia, it is reported that there is no need for prioritizing regulations, because all children are guaranteed a place in child care from the age of one year. 


\section{Summary Finding 16}

Prioritizing regulations or targeting strategies to allocate ECE places preferentially are commonly used in the study countries at national and/or local level. The study countries use a range of social, developmental and economic criteria to focus the targeting strategies, with the most common prioritizing regulations aimed at enhancing the participation in ECE of children from low-income families, and children with special educational needs or disability.

\section{Diversity and Cultural Responsiveness of Settings}

The capacity of ECE services to deal with diversity in the child population has been shown to be a clear factor in the delivery of quality ECE services, increased participation of children in the services and the achievement of positive educational outcomes (Reid, \& Kagan, 2015; Reid, \& Ready, 2013; Sylva et al., 2008). The evidence from these studies show that developing ECE provision for diversity leads to enhanced child participation and better outcomes for the less advantaged.

The ECES policy data identified a possible range of policy strategies used in the study countries to ensure ECE settings support and facilitate diversity and cultural responsiveness (Table 14). These strategies included: legislation to ensure cultural diversity is respected in ECE programs; prioritized access to ECE for certain cultural groups; controlled eligibility requirements for ECE programs; promotion of cultural diversity in ECE programs, including linguistic diversity; training of staff to ensure cultural diversity is respected in ECE programs; additional specialist staff to support cultural diversity; targeted recruitment of staff to ensure cultural diversity is reflected in settings; additional budget to support cultural diversity; and additional equipment to support cultural diversity.

All the study countries have strategies to facilitate cultural diversity in ECE programs, except at the ECED level in the Czech Republic and Poland (Table 14). In all the study countries this includes legislation to ensure cultural diversity is respected in ECE programs. In Chile, for example, the first paragraph of the General Law on Education (Law 20.370) states that the education system should promote and ensure the diversity of educational processes and programs, as well as the cultural, religious and social diversity of their students. It also states that the educational system should recognize the ethnic background of all the students. In Denmark, law prescribes cultural diversity in all ECE centers. In Italy, Law 295/1997 specifically provides funds for projects that aim to support foreign minors and provide affirmative actions for the respect of diversity, including the cultural diversity of ethnic minorities. Based on this law, ECED centers have been created with specific attention to cultural diversity. At PPE level, Chilean JUNJI has an alternative program, called the Intercultural Preschool, which supports children from two to five years of age from the native communities. In the Russian Federation, the legal standards for preschool education require settings to take into account the ethno-cultural background of the child and ensure equal opportunities for each child regardless of residence, gender, nationality, language, social status and other features. Diversity is also supported through the requirements of the educational program. 
Table 14: Diversity and cultural responsiveness strategies for children aged 0-3 years (ECED) and children aged from 3 years to the start of primary schooling (PPE)

\begin{tabular}{|c|c|c|c|c|c|c|c|c|c|c|}
\hline \multirow[b]{2}{*}{ Country } & \multirow[b]{2}{*}{ Level } & \multicolumn{9}{|c|}{ Strategies to facilitate cultural diversity } \\
\hline & & 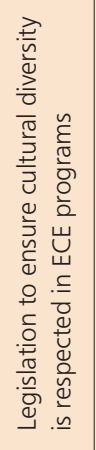 & 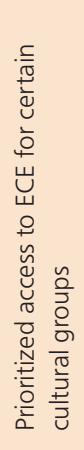 & 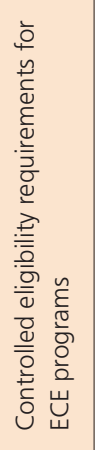 & 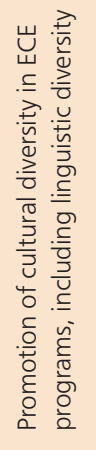 & 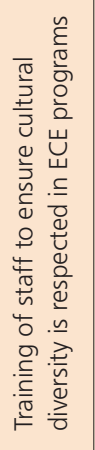 & 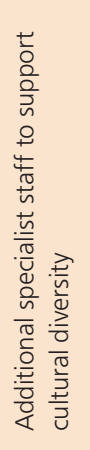 & 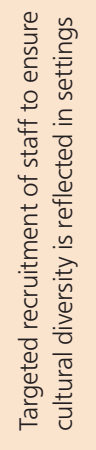 & 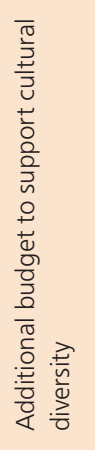 & 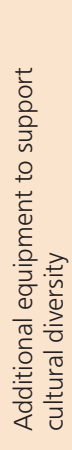 \\
\hline \multirow[t]{2}{*}{ Chile } & ECED & $\bullet$ & O & O & O & O & O & O & O & O \\
\hline & PPE & $\bullet$ & O & o & $\bullet$ & O & O & O & O & O \\
\hline \multirow[t]{2}{*}{ Czech Republic } & ECED & - & - & - & - & - & - & - & - & - \\
\hline & PPE & $\bullet$ & O & o & $\bullet$ & $\bullet$ & $\bullet$ & O & O & O \\
\hline \multirow[t]{2}{*}{ Denmark } & ECED & $\bullet$ & O & $\bullet$ & $\bullet$ & O & O & O & 0 & 0 \\
\hline & PPE & $\bullet$ & 0 & $\bullet$ & $\bullet$ & o & O & O & o & 0 \\
\hline \multirow[t]{2}{*}{ Estonia } & ECED & $\bullet$ & $\bullet$ & $\bullet$ & $\bullet$ & $\bullet$ & $\bullet$ & $\bullet$ & $\bullet$ & $\bullet$ \\
\hline & PPE & $\bullet$ & $\bullet$ & $\bullet$ & $\bullet$ & $\bullet$ & $\bullet$ & - & $\bullet$ & $\bullet$ \\
\hline \multirow[t]{2}{*}{ Italy } & ECED & $\bullet$ & o & o & $\bullet$ & o & 0 & o & 0 & 0 \\
\hline & PPE & $\bullet$ & 0 & 0 & $\bullet$ & $\bullet$ & O & O & $\bullet$ & O \\
\hline \multirow[t]{2}{*}{ Poland } & ECED & - & - & - & - & - & - & - & - & - \\
\hline & PPE & $\bullet$ & 0 & 0 & O & o & 0 & O & 0 & 0 \\
\hline \multirow{2}{*}{$\begin{array}{l}\text { Russian } \\
\text { Federation }\end{array}$} & ECED & $\bullet$ & 0 & o & $\bullet$ & 0 & O & O & 0 & 0 \\
\hline & PPE & $\bullet$ & 0 & 0 & $\bullet$ & 0 & 0 & 0 & 0 & O \\
\hline \multirow[t]{2}{*}{ United States } & ECED & $\bullet$ & $\bullet$ & $\bullet$ & $\bullet$ & $\bullet$ & $\bullet$ & $\bullet$ & $\bullet$ & $\bullet$ \\
\hline & PPE & $\bullet$ & $\bullet$ & - & $\bullet$ & $\bullet$ & $\bullet$ & $\bullet$ & $\bullet$ & $\bullet$ \\
\hline $\begin{array}{ll}\text { Key: } \\
\text { - } \\
\text { O } & \text { Yes, strat } \\
\text { O } & \text { No, strat } \\
- & \text { Strategie }\end{array}$ & a a sp & †OC & 8 & t. & a level & & & & & \\
\hline
\end{tabular}

A range of other strategies are also used to achieve cultural responsiveness in practice in the study countries. The most commonly used strategy is the active and positive promotion of cultural diversity, including linguistic diversity, which is evident in Denmark, Estonia, the Russian Federation and the United States for both ECED and PPE services, and in Chile and the Czech Republic for PPE services. Italy employs a range of strategies, with a recent particular emphasis on the integration of migrant children into the educational system. There is also a limit of $30 \%$ of foreign children per classroom to ensure proper care is given to such children, starting from PPE. 


\section{Summary Finding 17}

The promotion of culturally and linguistically responsive practices in ECE settings to increase the enrollment and participation of children from diverse social and cultural backgrounds is evident in all the study countries, and backed up by legislation.

\section{Coverage and Availability of ECE Provision}

There have been several international reports that have encouraged a universal approach to ECE access, with particular attention to improving coverage and availability of ECE for children below the age of three years and to children from low-income homes and with special needs or disability (Corak et al., 2012; EIU, 2012; OECD, 2012b, 2013; Pascal, \& Bertram, 2012). The potential benefits to children's developmental outcomes are a key part of the rationale for improving participation in ECE services. These reports also state that more attention needs to be devoted to:

- Providing universal and responsive services for all three- to six-year-olds to ensure provision meets the needs of a particular child or his or her parent(s). For example, a child may have special learning needs and require an inclusive program in the local center, or working parents may need flexible and year-round opening hours.

- Expanding provision for infants and toddlers to ensure it is affordable and available for all children.

- Ensuring equitable access to ECE, such that all children have equal opportunities to attend quality ECE, regardless of family income, parental employment status, special educational needs, or ethnic/language background.

- Ensuring there is coverage of provision in all geographic areas, particularly rural and remote areas where sustainability of ECE services can be more difficult due to a dispersed and less dense population.

Admissions policies define how all children will be considered for entry into a setting and any order of priority that will be applied if there are insufficient places to meet demand. Settings may serve a particular age group, religion/community, or have other entry criteria which determine the profile of the families that they serve. Children may only be accepted if they have reached a certain developmental stage (such as being able to use the toilet independently) and this may affect the acceptance of children with physical disabilities or developmental delay. For settings which are not free at the point of provision, parents' ability to pay will affect which settings their children are able to attend.

Universal coverage (as opposed to universal entitlement) of ECE services at ECED and PPE levels varies among the study countries (Table 15). In some countries universal coverage does not exist, and NRCs provided information on areas of limited service availability, in particular service coverage for children living in rural areas, children from low-income families and children with special needs or disability.

Denmark, Estonia and the Russian Federation have universal coverage of services for children under the age of three (ECED), and Chile, the Czech Republic, Italy, Poland and the United States do not (Table 15). For children from three years to primary school age (PPE), six of the eight study countries have universal coverage of services, including 
Table 15: Existence of universal coverage of services for children aged 0-3 years (ECED) and children aged 3 to the start of primary school (PPE) and areas of limited service availability

\begin{tabular}{|c|c|c|c|c|c|}
\hline \multirow[b]{2}{*}{ Country } & \multirow[b]{2}{*}{ Level } & \multirow[b]{2}{*}{$\begin{array}{l}\text { Existence of ECE } \\
\text { universal coverage }\end{array}$} & \multicolumn{3}{|c|}{ Areas of limited availability of ECE services } \\
\hline & & & Rural areas & $\begin{array}{l}\text { Low-income } \\
\text { families }\end{array}$ & $\begin{array}{l}\text { Children with } \\
\text { special needs or } \\
\text { disability }\end{array}$ \\
\hline \multirow[t]{2}{*}{ Chile } & ECED & $\diamond$ & $\bullet$ & ○ & - \\
\hline & PPE & 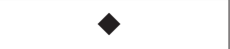 & - a & O & O \\
\hline \multirow[t]{2}{*}{ Czech Republic } & ECED & $\diamond$ & - & - & - \\
\hline & PPE & $\diamond$ & O & 0 & O \\
\hline \multirow[t]{2}{*}{ Denmark } & ECED & $\diamond$ & O & ○ & ○ \\
\hline & PPE & $\diamond$ & 0 & O & O \\
\hline \multirow[t]{2}{*}{ Estonia } & ECED & $\diamond$ & 0 & O & O \\
\hline & PPE & $\diamond$ & O & 0 & O \\
\hline \multirow[t]{2}{*}{ Italy } & ECED & $\diamond_{b}$ & - & - & - \\
\hline & PPE & $\diamond c$ & - & - & - \\
\hline \multirow[t]{2}{*}{ Poland } & ECED & $\diamond$ & - & - & - \\
\hline & PPE ${ }^{a}$ & $\bullet$ & - d & - & - \\
\hline \multirow{2}{*}{$\begin{array}{l}\text { Russian } \\
\text { Federation }\end{array}$} & ECED & $\diamond$ & O & O & O \\
\hline & PPE & $\boldsymbol{\nu}^{\mathrm{e}}$ & O & O & O \\
\hline \multirow[t]{2}{*}{ United States } & ECED & $\diamond$ & 0 & $\bullet$ & $\bullet$ \\
\hline & PPE & $\Delta_{f}$ & 0 & - & - \\
\hline
\end{tabular}

Key:

Existence of universal coverage:

- Yes.

$\diamond$ No.

Limited availability

- Yes.

O No.

- No data available.

Country specific notes:

a Chile: There is universal coverage in PPE only for children from four years therefore there is limited availability for children in rural areas between three to four years.

b Italy: ECED is not available for all children. Poorer coverage and availability in ECED are not limited to certain groups only, but for the entire 0-3 population, since there are very few centers opened compared to the potential demand. This is especially true in the south of Italy, where PPE centers are partially subsidizing ECED with the free provision of Sezioni Primavera for children 24-36 months old and with anticipated enrollments. ECE coverage could also be limited in big cities, but there are no national data to back this statement.

c Italy: PPE is promoted as a universal public service, free of charge for families, but it does not have universal coverage as it is not mandatory; coverage is high, but has been declining in recent years. The lack of data prevents a detailed analysis of the population segments mostly affected by this decline.

d Poland: Although there is universal coverage in theory, in practice this does not secure a place in PPE until a child is five years old (and from September 2015 this applies for four-year-olds) when they have to attend compulsory one year of preschool. In all other cases, parents apply for a place in PPE, but in certain rural areas of Poland there is a shortage of places for three- and four-year-olds.

e Russia: Although there is universal coverage, there are certain areas that have a shortage of PPE places as a result of the 2006-2013 "baby boom."

f United States: Kindergarten (the final year of ISCED Level 0) could be considered universal, however the earlier years of PPE have limited availability. 
Chile, the Czech Republic, Denmark, Estonia, Poland and the Russian Federation; Italy and the United States have not achieved universal coverage. More countries report universal coverage as children move into PPE. Italy and the United States both report that, even though there is no universal coverage, during the final year of PPE coverage could be considered universal, as there is almost universal access. Even where universal entitlement to services exists, some study countries report a shortage of provision, particularly in rural areas (Chile, Estonia and Poland), for low-income families (Estonia and the United States), and for children with special needs or disability (Estonia and the United States).

\section{Summary Finding 18}

There is more universal coverage of ECE services at PPE level than at ECED level. Shortage in ECE places is greater for children under the age of three years, and these shortages can be more acute for children living in rural areas, from a low-income family, or who have special needs or disability.

Where universal coverage is not available and barriers to participation in ECE exist for certain groups, some countries have adopted national strategies to increase service coverage and encourage participation (EIU, 2012; Pascal, \& Bertram, 2012). Such strategies might include: increasing geographical coverage in urban or rural areas and low-income neighborhoods; encouraging the extension of all year round services, including holiday periods; extending the hours of opening to include early morning and later evening opening; and introducing full week opening, including weekends. The eight study countries have various strategies to increase coverage of ECE services (Table 16).

Seven of the study countries have adopted national strategies to increase the coverage of ECE services (Table 16). Chile, Denmark, Estonia, Italy and the Russian Federation have national strategies that include both ECED and PPE level services; in the Czech Republic, such strategies were aimed at PPE level services only, and, in Poland, they were aimed at ECED level services only. Among the study countries, the most common strategy aims to increase geographical coverage of the provision, in rural or urban areas, or in low-income neighborhoods (Chile and Denmark). Chile and Estonia have also increased opening hours and encouraged all year round availability of services.

The Czech Republic stated that they have a long-term strategy to increase capacity in schools in areas where provision levels are low, and to extend the age covered by PPE so that two-year-olds are officially included. Italy reported that there is an effort to increase coverage of ECE services, especially for children under the age of three years (ECED), by offering funding to increase the number of new places where coverage is low. Poland is also providing capital grants to create more ECE services in certain geographical areas. In the Russian Federation, there has been an increase in the number of children allowed within child:staff ratios to extend the coverage of services. 
Table 16: Strategies to increase coverage of ECE provision for children aged 0-3 years (ECED) and children aged 3 to the start of primary school (PPE)

\begin{tabular}{|c|c|c|c|c|c|c|c|}
\hline \multirow[b]{2}{*}{ Country } & \multirow[b]{2}{*}{ Level } & \multirow[b]{2}{*}{ 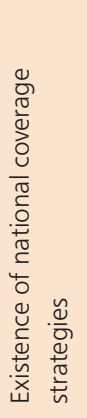 } & \multicolumn{5}{|c|}{ Strategies to increase coverage of ECE } \\
\hline & & & 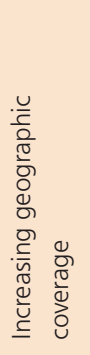 & 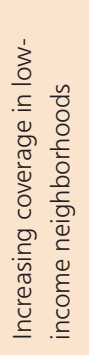 & 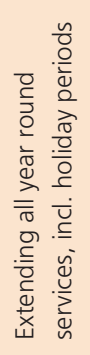 & 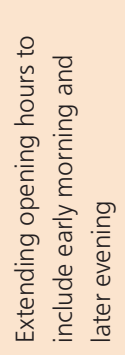 & 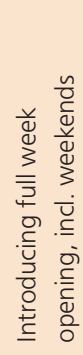 \\
\hline \multirow[t]{2}{*}{ Chile } & ECED & $\diamond$ & $\bullet$ & $\bullet$ & $\bullet$ & $\bullet$ & $\mathrm{O}$ \\
\hline & PPE & $\diamond$ & $\bullet$ & $\bullet$ & $\bullet$ & $\bullet$ & O \\
\hline \multirow[t]{2}{*}{ Czech Republic } & ECED & $\diamond$ & $\mathrm{n} / \mathrm{a}$ & $\mathrm{n} / \mathrm{a}$ & $\mathrm{n} / \mathrm{a}$ & $\mathrm{n} / \mathrm{a}$ & $\mathrm{n} / \mathrm{a}$ \\
\hline & PPE & $\diamond$ & O & O & O & O & O \\
\hline \multirow[t]{2}{*}{ Denmark } & ECED & $\diamond$ & $\bullet$ & $\bullet$ & $\bullet$ & O & O \\
\hline & PPE & $\diamond$ & $\bullet$ & $\bullet$ & $\bullet$ & O & O \\
\hline \multirow[t]{2}{*}{ Estonia } & ECED & $\bullet$ & $\bullet$ & O & $\bullet$ & $\bullet$ & 0 \\
\hline & PPE & $\diamond$ & $\bullet$ & O & $\bullet$ & $\bullet$ & O \\
\hline \multirow[t]{2}{*}{ Italy } & ECED & $\diamond$ & $\bullet$ & O & O & O & O \\
\hline & PPE & $\diamond$ & $\bullet$ & O & O & 0 & 0 \\
\hline \multirow[t]{2}{*}{ Poland } & ECED & $\diamond$ & $\bullet$ & O & 0 & O & O \\
\hline & PPE & $\diamond$ & $n / a$ & $n / a$ & $n / a$ & $n / a$ & $n / a$ \\
\hline \multirow{2}{*}{$\begin{array}{l}\text { Russian } \\
\text { Federation }\end{array}$} & ECED & $\bullet$ & $\bullet$ & O & O & O & O \\
\hline & PPE & $\bullet$ & $\bullet$ & O & 0 & 0 & 0 \\
\hline \multirow[t]{2}{*}{ United States } & ECED & $\diamond$ & $\mathrm{n} / \mathrm{a}$ & $n / a$ & $n / a$ & $n / a$ & $\mathrm{n} / \mathrm{a}$ \\
\hline & PPE & $\diamond$ & $n / a$ & $\mathrm{n} / \mathrm{a}$ & $\mathrm{n} / \mathrm{a}$ & $\mathrm{n} / \mathrm{a}$ & $\mathrm{n} / \mathrm{a}$ \\
\hline
\end{tabular}

Key:

Existence of national or typical subnational ECE coverage strategies:

$\diamond$ Yes.

$\diamond$ No.

Types of strategies:

- Yes.

O No.

- Not applicable.

\section{Summary Finding 19}

In the seven study countries where there is a national commitment to achieve universal coverage of ECE services, strategies have been adopted to increase the geographic coverage of services and to extend their opening hours, in order to enhance the participation of all children. 


\section{Costs to Parents for Participation in ECE}

In most countries, costs for ECE are shared between parents and governments. In only a few countries is the public provision of high-quality ECE for children considered an entitlement for a child, on an equal footing with services for the older children, and funded as such. Even where there is universal ECE provision, parental fees are often charged up to the year before entry into compulsory schooling, but costs to parents are generally low; sometimes fees are based on parental income and sometimes they are capped at a limit, with low-income groups paying only token fees. OECD (2013) data showed that in the continental European countries, public ECE programs largely predominated, and parents contributed on average $25-30 \%$ to their costs. Countries such as Belgium, France and the Netherlands provide universal and free early education services to children from a young age. In other countries, the parental share of funding is significantly higher, and can be up to $82 \%$ of costs in some Canadian provinces and full costs in many American services. Australia is unusual in that fee support (the Child Care Benefit and a new $30 \%$ child care tax rebate) is available to $98 \%$ of parents, with low-income parents receiving a higher benefit. This means that approximately $60 \%$ of expenditure on all early childhood services is public, with parents contributing in total about $38 \%$ of costs. The general picture then is that, in Europe, governments contribute about $66-90 \%$ of costs, and parents pay less than one-third. In many other countries, the situation is reversed, with parents paying the major share and governments providing about one-third of costs (Australia about 60\%). The evidence is that this high cost to parents has become a real disincentive to women remaining in the labor force, particularly if a second child is born; it also impacts directly on some children accessing high-quality ECE services, which can enhance their developmental outcomes (Corak et al., 2012; EIU, 2012; Pascal, \& Bertram, 2012).

Differences in ECE fee structures will partly depend on governmental funding of ECE. The fee structure varies across countries and is dependent on national policy decisions about the balance of public and private funding, as well as on the types of ECE provision available (OECD, 2012a). Even within Europe, where there is more publicly-funded provision, the level of subsidy varies: for example, one study found that the share that parents paid ranged from 8\% in Sweden to 80\% in Poland (Janta, 2009).

The ECES explored the proportion of ECE costs borne by parents for accessing ECE services in the eight participating countries. The study countries reported that accessing data about costs of ECE borne by parents is very difficult and, in many cases, data could not be reported, only estimated figures could be provided, or just an overall statement about the balance of the costs borne by parents could be supplied.

The data provided suggest that, in the study countries, the costs to parents for their child's ECE participation varies considerably from no cost to around $25 \%$ of costs. For example, in Chile, for children under four years old, public provision is free and so there is no cost to parents. Private subsidized services for children from four years to primary school may charge fees (which might be subsidized) to parents, and, in fully private provision, parents bear all the costs. In Denmark, parents pay $25 \%$ of the fees for services from birth to six years (ECE). In Estonia, the Preschool Childcare Institution Act states that the amount covered by parents per child must not exceed $20 \%$ of the minimum wage rate established by the government. In Italy, it is estimated that the costs borne by parents are approximately 19.2\% of total ECED costs (Istat, 
2014; data referring to 2012). In the United States, the cost of ECE borne by parents ranges from $8 \%$ for children less than one year of age to $5 \%$ for children from five to six years of age, generally decreasing with the age of the child.

\section{Summary Finding 20}

The findings from the study countries indicate that ascertaining the costs of ECE services to parents can be difficult, as charging policy and practice are generally not nationally documented. However, where free, universal, publicly-funded ECE services are unavailable, there is evidence that these costs can constitute a significant proportion of household income. It also implies that the costs to parents may be a significant factor when looking at levels of child enrollment in ECE services.

\section{Targeted Early Intervention Programs}

Cost-benefit analysis of investment in high-quality early education programs (Heckman, 2012) demonstrates that the highest per child benefits stem from programs that target economically disadvantaged children. Indeed, studies have shown that these children make significant gains in cognition, social-emotional development, and educational performance when they participate in high-quality early education programs, relative to children who do not participate (Corak et al., 2012; Pascal, \& Bertram, 2012; Sylva et al., 2008). Lynch (2007) identified the benefits from investment targeted to lower-income families. This research indicated that targeted investments, while less ambitious (costing roughly $25 \%$ of the costs of universal investment), would yield higher benefits, as children from middle- and high-income households are likely to already receive higher quality educational development in their prekindergarten years. Research suggests that there are certain subgroups in the population targeted for early intervention (Corak et al., 2012; EIU, 2012; Pascal, \& Bertram, 2012). These subgroups include low-income families, children with special needs or disability, minority ethnic groups, and children for whom the home language spoken is other than the national language (Table 17).

All of the study countries, except Italy, have targeted intervention programs (Table 17), which suggests that they are well aware of the benefits of these targeted programs. These programs are also evident in the many of the countries that offer universal publicly-funded ECE services. In Italy universal access and inclusion are provided as an alternative to programs targeting specific groups in the population. However, although there are no strategies for additional support to specific groups in Italy, it is reported that low-income families may apply for vouchers or subsidies based on family income level. Within ECE services, there are also teachers who are specialized in teaching disabled children.

In the majority of study countries, the intervention programs are implemented in both the ECED and PPE age phases, but, in the Czech Republic, they are implemented at PPE level only. All the identified subgroups are targeted in the study countries that have intervention programs, with the exception of Chile which, during the ECED phase, does not target children with special needs or disability or children whose home language differs from the official national language. Low-income families and minority ethnic groups are targeted for early intervention in all the study countries that have a national intervention strategy. 
Table 17: Existence of targeted early intervention programs at target groups for children aged 0-3 years (ECED) and children aged 3 to the start of primary schooling (PPE)

\begin{tabular}{|c|c|c|c|c|c|}
\hline \multirow[b]{2}{*}{ Country } & \multirow[b]{2}{*}{ Level } & \multicolumn{4}{|c|}{ Target groups for early intervention programs } \\
\hline & & $\begin{array}{l}\text { Low-income } \\
\text { families }\end{array}$ & $\begin{array}{l}\text { Children with } \\
\text { special needs } \\
\text { disability }\end{array}$ & $\begin{array}{l}\text { Minority } \\
\text { ethnic } \\
\text { groups }\end{array}$ & $\begin{array}{c}\text { Language spoken at } \\
\text { home is different to } \\
\text { national language }\end{array}$ \\
\hline \multirow[t]{2}{*}{ Chile } & ECED & $\bullet$ & - & $\bullet$ & - \\
\hline & PPE & $\bullet$ & $\bullet$ & $\bullet$ & - \\
\hline \multirow[t]{2}{*}{ Czech Republic } & ECED & - & - & - & - \\
\hline & PPE & $\bullet$ & $\bullet$ & $\bullet$ & $\bullet$ \\
\hline \multirow[t]{2}{*}{ Denmark } & ECED & $\bullet$ & $\bullet$ & $\bullet$ & $\bullet$ \\
\hline & PPE & $\bullet$ & $\bullet$ & $\bullet$ & $\bullet$ \\
\hline \multirow[t]{2}{*}{ Estonia } & ECED & $\bullet$ & $\bullet$ & $\bullet$ & $\bullet$ \\
\hline & PPE & $\bullet$ & $\bullet$ & $\bullet$ & $\bullet$ \\
\hline \multirow[t]{2}{*}{ Italy } & ECED & - & - & - & - \\
\hline & PPE & - & - & - & - \\
\hline \multirow[t]{2}{*}{ Poland } & ECED & $\bullet$ & $\bullet$ & $\bullet$ & $\bullet$ \\
\hline & PPE & $\bullet$ & $\bullet$ & $\bullet$ & $\bullet$ \\
\hline \multirow{2}{*}{$\begin{array}{l}\text { Russian } \\
\text { Federation }\end{array}$} & ECED & $\bullet$ & $\bullet$ & $\bullet$ & $\bullet$ \\
\hline & PPE & $\bullet$ & $\bullet$ & $\bullet$ & $\bullet$ \\
\hline \multirow[t]{2}{*}{ United States } & ECED & $\bullet$ & $\bullet$ & $\bullet$ & - \\
\hline & PPE & $\bullet$ & $\bullet$ & $\bullet$ & - \\
\hline
\end{tabular}

Key:

- Existence of targeted intervention programs at national or typical subnational level.

- $\quad$ Targeted intervention programs do not exist at national or typical subnational level.

In Estonia, there is a particular focus on early intervention for children whose home language differs from the national language. It is reported that, in 50\% of ECE settings, specialist professional staff are provided to support the targeted groups with speech and language therapists and "special" pedagogues. If progress cannot be made with the child's language development, the preschools and parents can access additional advice from regional centers offering a wider range of specialist support. In those settings where the education is not conducted in Estonian, there is specialist support offered for Estonian language training. In cooperation with the National Examinations and Qualifications Center and Lasteveeb Open University, internet-based study material has also been developed to support the learning of Estonian as a second language for preschool children. The Russian Federation provides targeted support programs at a regional level, which offer support for minority ethnic groups. The United States provides resources to support culturally and linguistically diverse communities. There are also programs such as Head Start that target certain populations, such as Native Americans and Alaska Native children and families. 


\section{Summary Finding 21}

Targeted intervention programs as part of ECE services are used extensively in the majority of study countries as a mechanism to provide additional and early support for children from low-income families, children from minority ethnic groups, children with special needs or disability, and children whose home language differs from the national language. The intervention may take a variety of forms, including input from specialist professionals, providing additional resources, running support groups, providing specialist advice, and accessing internet-based study material.

Open Access This chapter is distributed under the terms of the Creative Commons AttributionNonCommercial 4.0 International License (http://creativecommons.org/licenses/by-nc/4.0/), which permits any noncommercial use, duplication, adaptation, distribution and reproduction in any medium or format, as long as you give appropriate credit to the original author(s) and the source, provide a link to the Creative Commons license and indicate if changes were made.

The images or other third party material in this chapter are included in the works Creative Commons license, unless indicated otherwise in the credit line; if such material is not included in the works Creative Commons license and the respective action is not permitted by statutory regulation, users will need to obtain permission from the license holder to duplicate, adapt or reproduce the material. 


\section{CHAPTER 7:}

\section{Supporting Quality in ECE}

Studies have shown that to have effective outcomes, ECE must also be of high quality (Barnett, 2012; Corak et al., 2012; Heckman et al., 2009, 2012). This chapter describes how quality in ECE is assured and maintained, including the regulatory environment; staff qualifications and training; group size and ratios; health, safety and child protection; ECE curriculum guidance; and quality assurance, inspection, reporting and accountability. These data provide readers with information on aspects often associated with quality ECE services for children and families, and how this quality is achieved, monitored and maintained. Within and between country similarities and variations in quality and monitoring will be highlighted.

International studies (Corak et al., 2012; EIU, 2012; OECD, 2010, 2012b, 2013; Pascal, Bertram, Delaney, \& Nelson, 2012; Sylva et al., 2004, 2008) indicate a clear relationship between ECE participation, especially participation in ECE settings with certain "quality" features, and later learning outcomes. The indicative quality indicators include child:staff ratios, staff qualifications and training, regulation and data use, the duration of programs, and public spending per child. A recent study (Pascal, \& Bertram, 2012) analyzed patterns and associations between these quality indicators and later PISA school outcome results, revealing that high-performing European countries in terms of school outcomes appear to have:

- Higher staff:child ratios (higher number of staff to number of children)

- Higher levels of staff qualification and training

- Relatively higher levels of regulation

- A government-led ECE policy strategy and higher levels of investment.

This study and others (for example, EIU, 2012) provide convincing evidence of the validity of five structural indicators as key policy levers within an early education system for reducing inequality, educational underachievement and social exclusion. These indicators are:

Indicator 1: staff:child ratios

Indicator 2: staff training and qualifications

Indicator 3: regulation and data collection

Indicator 4: government strategy and investment

Indicator 5: national preschool curriculum requirements.

These quality indicators are covered in the data presented in this report.

\section{Regulatory Environment}

There is evidence (Corak et al., 2012; Pascal et al., 2012) that reforms to bring in better regulation and accountability in the early years sector can foster improvements in service delivery and improved outcomes for children. The development of enhanced statutory standards, a comprehensive regulatory framework, and more efficient systems to manage data, measure quality, and evidence the impact of practice are generally associated with better quality, more effective targeting, the efficient deployment of resources at all levels, and improved outcomes, particularly for the less advantaged. Research (Pascal et al., 2012) has also shown that the presence and efficiency of regulation varies widely across 
countries, from highly regulated ECE services to minimally regulated services with a strong association between the presence and efficiency of ECE regulatory systems and later school performance.

Given the wider evidence on the role of regulation in ECE quality assurance, the ECES collected information from the eight study countries on whether or not regulatory bodies exist for ECED and PPE services, and, if so, whether these bodies operate at national or subnational level in the country and what aspects of ECE provision the regulatory bodies cover at these different levels. The aspects of ECE regulation identified by the study countries included:

- Authorization to open a setting

- Accreditation for public funding or subsidy

- Financing

- Staff qualifications and training

- Staff professional development

- Staff licensing and accreditation

- Staff remuneration

- Equal opportunities for staffing

- Group size

- Child:staff ratios

- Opening hours

- Health and safety

- Environmental requirements (for example, space or access to outdoor play)

- ECE curriculum or program

- Parental participation

- Child protection

- Quality assurance and inspection

- Reporting and accountability.

All eight of the study countries reported that they have ECE regulatory bodies at both national (Table 18a) and subnational (Table 18b) levels, and that responsibility for different aspects of quality regulation are distributed between bodies that operate at both levels. In this context, subnational is taken to mean where responsibility is delegated to a level below that of the whole country or national level. This will include both federal systems, where a state or province has constitutional authority for the area, and non-federal systems where a regional administrative body has delegated responsibility (but which is not the highest point of responsibility).

In the majority of the study countries, there is both national and subnational regulation for ECED and PPE services (the exception being the Czech Republic where no regulation is reported at subnational level for ECED) (Tables 18a and 18b). However, the balance between national and subnational regulation differs among countries, with Chile, the Czech Republic and Estonia having more national regulation, the Russian Federation having more subnational regulation, and Denmark, Italy, Poland, and the United States reporting regulatory responsibilities at both the national and subnational level. Some countries also appear to be more highly regulated than others, with the Czech Republic 
Table 18a: Regulatory responsibilities at national level for children aged $0-3$ years (ECED) and children aged 3 to the start of primary school (PPE)

\begin{tabular}{|c|c|c|c|c|c|c|c|c|c|c|c|c|c|c|c|c|c|c|c|}
\hline \multirow[b]{2}{*}{ Country } & \multirow[b]{2}{*}{ Level } & \multicolumn{18}{|c|}{ Aspects of ECE where responsibility is located at national level } \\
\hline & & 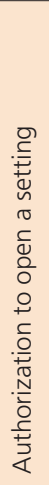 & 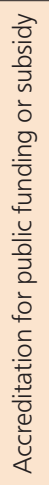 & 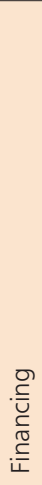 & 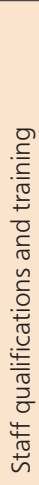 & 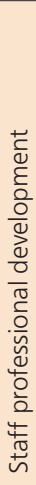 & 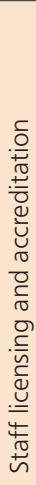 & 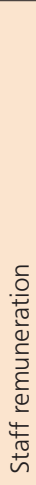 & 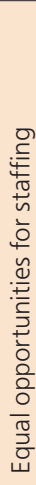 & $\begin{array}{l}\frac{N}{n} \\
\frac{0}{3} \\
\frac{0}{v}\end{array}$ & 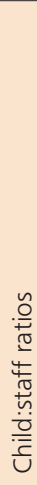 & 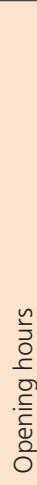 & 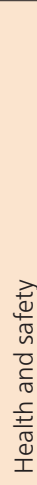 & 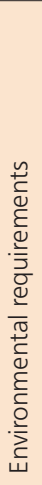 & 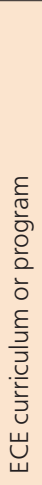 & 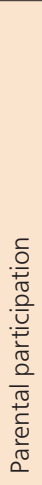 & 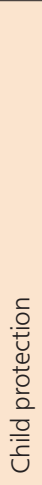 & 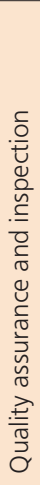 & 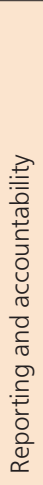 \\
\hline \multirow[t]{2}{*}{ Chile } & ECED & $\bullet$ & $\bullet$ & $\bullet$ & $\bullet$ & $\bullet$ & O & $\bullet$ & O & $\bullet$ & $\bullet$ & $\bullet$ & $\bullet$ & $\bullet$ & $\bullet$ & $\bullet$ & $\bullet$ & $\bullet$ & $\bullet$ \\
\hline & PPE & $\bullet$ & $\bullet$ & $\bullet$ & $\bullet$ & $\bullet$ & O & $\bullet$ & O & $\bullet$ & $\bullet$ & $\bullet$ & $\bullet$ & $\bullet$ & $\bullet$ & $\bullet$ & $\bullet$ & $\bullet$ & $\bullet$ \\
\hline \multirow[t]{2}{*}{ Czech Republic } & ECED & - & - & - & $\bullet$ & - & - & - & - & - & - & - & $\bullet$ & - & - & - & - & - & - \\
\hline & PPE & $\bullet$ & $\bullet$ & $\bullet$ & $\bullet$ & $\bullet$ & 0 & $\bullet$ & - & $\bullet$ & $\bullet$ & 0 & $\bullet$ & $\bullet$ & $\bullet$ & $\bullet$ & $\bullet$ & $\bullet$ & $\bullet$ \\
\hline \multirow[t]{2}{*}{ Denmark } & ECED & -a & $-{ }^{\mathrm{b}}$ & $\bullet$ & $\bullet$ & $\bullet$ & - & $\bullet$ & o & O & O & O & $\bullet$ & $\bullet$ & $\bullet$ & 0 & $\bullet$ & $\bullet$ & $\bullet$ \\
\hline & PPE & $e^{a}$ & $-{ }^{\mathrm{b}}$ & $\bullet$ & $\bullet$ & $\bullet$ & $\bullet$ & $\bullet$ & O & O & O & O & $\bullet$ & $\bullet$ & $\bullet$ & 0 & $\bullet$ & $\bullet$ & $\bullet$ \\
\hline \multirow[t]{2}{*}{ Estonia } & ECED & $\bullet$ & $\bullet$ & - & $\bullet$ & $\bullet$ & $\bullet$ & - & $\bullet$ & $\bullet$ & $\bullet$ & - & $\bullet$ & $\bullet$ & $\bullet$ & - & $\bullet$ & $\bullet$ & - \\
\hline & PPE & $\bullet$ & $\bullet$ & - & $\bullet$ & $\bullet$ & $\bullet$ & - & $\bullet$ & $\bullet$ & $\bullet$ & - & $\bullet$ & $\bullet$ & $\bullet$ & $\bullet$ & $\bullet$ & $\bullet$ & - \\
\hline \multirow[t]{2}{*}{ Italy } & ECED & $\bullet$ & $\bullet$ & $\bullet$ & $\bullet$ & $\bullet$ & $\bullet$ & $\bullet$ & $\bullet$ & $\bullet$ & $\bullet$ & $\bullet$ & $\bullet$ & $\bullet$ & O & $\bullet$ & $\bullet$ & $\bullet$ & $\bullet$ \\
\hline & PPE & $\bullet$ & $\bullet$ & $\bullet$ & $\bullet$ & $\bullet$ & $\bullet$ & $\bullet$ & $\bullet$ & $\bullet$ & $\bullet$ & $\bullet$ & $\bullet$ & $\bullet$ & $\bullet$ & $\bullet$ & $\bullet$ & $\bullet$ & $\bullet$ \\
\hline \multirow[t]{2}{*}{ Poland } & ECED & 0 & $\bullet$ & $\bullet$ & 0 & O & O & 0 & $\bullet$ & O & $\bullet$ & O & $\bullet$ & 0 & 0 & O & $\bullet$ & $\bullet$ & $\bullet$ \\
\hline & PPE & 0 & $\bullet$ & $\bullet$ & $\bullet$ & $\bullet$ & $\bullet$ & $\bullet$ & $\bullet$ & $\bullet$ & $\bullet$ & o & $\bullet$ & $\bullet$ & $\bullet$ & 0 & $\bullet$ & $\bullet$ & $\bullet$ \\
\hline \multirow{2}{*}{$\begin{array}{l}\text { Russian } \\
\text { Federation }\end{array}$} & ECED & 0 & 0 & 0 & $\bullet$ & O & O & $\bullet$ & O & $\bullet$ & $\mathrm{O}$ & O & $\bullet$ & $\bullet$ & O & $\bullet$ & $\bullet$ & $\bullet$ & $\bullet$ \\
\hline & PPE & O & O & $\bullet$ & $\bullet$ & O & O & $\bullet$ & O & $\bullet$ & O & O & $\bullet$ & $\bullet$ & O & $\bullet$ & $\bullet$ & $\bullet$ & $\bullet$ \\
\hline \multirow[t]{2}{*}{ United States c } & ECED & $\bullet$ & 0 & $\bullet$ & • & • & - & 0 & - & • & • & 0 & • & • & 0 & • & • & $\bullet$ & • \\
\hline & PPE & $\bullet$ & 0 & - & $\bullet$ & $\bullet$ & • & 0 & $\bullet$ & $\bullet$ & $\bullet$ & 0 & $\bullet$ & $\bullet$ & 0 & $\bullet$ & $\bullet$ & $\bullet$ & • \\
\hline
\end{tabular}

Key:

- Yes, regulation responsibility exists.

- No, regulation responsibility does not exist.

- No data provided.

\section{Country specific notes:}

a In Denmark, local communities can authorize a setting without asking the state, but all settings are regulated under the national law on dagtilud (Chapter $3 \S 20)$; thus establishment is local but regulation is national. The same is true for reporting and accountability.

b No data is supplied for Denmark, as public funding and subsidies are available to all. At local level, municipalities can decide to give increased funding to certain centers.

c For PPE within the United States, these aspects may vary among state funded and non-state funded settings for three-year-olds to 5-year-oldsnot-yet-in-kindergarten compared to kindergarten. 
Table 18b: Regulatory responsibilities at subnational level for children aged 0-3 years (ECED) and children aged 3 to the start of primary school (PPE)

\begin{tabular}{|c|c|c|c|c|c|c|c|c|c|c|c|c|c|c|c|c|c|c|c|}
\hline \multirow[b]{2}{*}{ Country } & \multirow[b]{2}{*}{ Level } & \multicolumn{18}{|c|}{ Aspects of ECE where responsibility is located at subnational level } \\
\hline & & 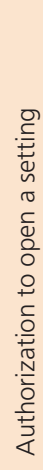 & 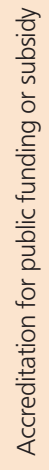 & 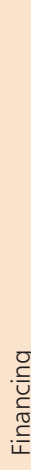 & 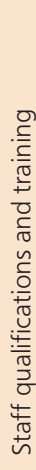 & 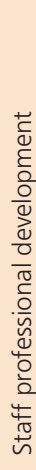 & 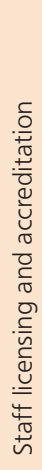 & 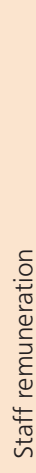 & 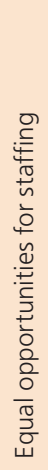 & 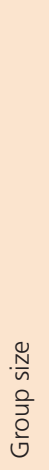 & 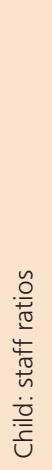 & 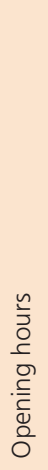 & 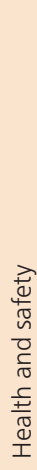 & 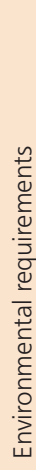 & 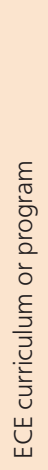 & 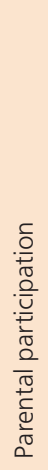 & 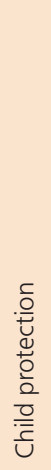 & 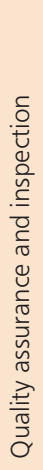 & 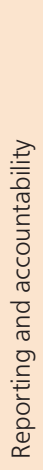 \\
\hline \multirow[t]{2}{*}{ Chile } & ECED & $\bullet$ & O & O & O & O & O & O & O & O & O & O & O & $\bullet$ & O & O & O & O & O \\
\hline & PPE & $\bullet$ & O & O & O & O & O & O & O & O & O & O & $\bullet$ & $\bullet$ & O & 0 & 0 & 0 & 0 \\
\hline \multirow[t]{2}{*}{ Czech Republic } & ECED & - & - & - & O & - & - & - & - & - & - & - & 0 & - & - & - & - & - & - \\
\hline & PPE & $\bullet$ & 0 & O & 0 & o & 0 & o & 0 & $\bullet$ & 0 & 0 & o & 0 & 0 & 0 & 0 & o & 0 \\
\hline \multirow[t]{2}{*}{ Denmark } & ECED & $\bullet$ & $\bullet$ & $\bullet$ & $\bullet$ & $\bullet$ & $\bullet$ & $\bullet$ & $\mathrm{O}^{\mathrm{b}}$ & $\mathrm{O}^{\mathrm{b}}$ & $\mathrm{O}^{\mathrm{b}}$ & $\mathrm{Ob}^{\mathrm{b}}$ & $\bullet$ & $\bullet$ & $\bullet$ & $\bullet$ & $\bullet$ & $\bullet$ & $\bullet$ \\
\hline & PPE & $\bullet$ & $\bullet$ & $\bullet$ & $\bullet$ & $\bullet$ & $\bullet$ & $\bullet$ & $\mathrm{O}^{\mathrm{b}}$ & $\mathrm{Ob}^{\mathrm{b}}$ & $\mathrm{O}^{\mathrm{b}}$ & $\mathrm{O}^{\mathrm{b}}$ & $\bullet$ & $\bullet$ & $\bullet$ & $\bullet$ & $\bullet$ & $\bullet$ & $\bullet$ \\
\hline \multirow[t]{2}{*}{ Estonia } & ECED & - & - & $\bullet$ & - & - & - & $\bullet$ & - & - & - & $\bullet$ & - & - & - & - & - & - & $\bullet$ \\
\hline & PPE & - & - & $\bullet$ & - & - & - & $\bullet$ & - & - & - & $\bullet$ & - & - & - & - & - & - & - \\
\hline \multirow[t]{2}{*}{ Italy } & ECED & $\bullet$ & $\bullet$ & $\bullet$ & • & $\bullet$ & $\bullet$ & $\bullet$ & $\bullet$ & $\bullet$ & $\bullet$ & $\bullet$ & $\bullet$ & $\bullet$ & $\bullet$ & $\bullet$ & $\bullet$ & $\bullet$ & $\bullet$ \\
\hline & PPE & $\bullet$ & $\bullet$ & $\bullet$ & $\bullet$ & $\bullet$ & $\bullet$ & $\bullet$ & $\bullet$ & $\bullet$ & $\bullet$ & $\bullet$ & $\bullet$ & $\bullet$ & $\bullet$ & $\bullet$ & $\bullet$ & $\bullet$ & $\bullet$ \\
\hline \multirow[t]{2}{*}{ Poland } & ECED & $\bullet$ & $\bullet$ & $\bullet$ & - & $\bullet$ & $\bullet$ & $\bullet$ & 0 & 0 & 0 & $\bullet$ & $\bullet$ & 0 & 0 & 0 & - & $\bullet$ & $\bullet$ \\
\hline & PPE & $\bullet$ & $\bullet$ & $\bullet$ & 0 & $\bullet$ & $\bullet$ & $\bullet$ & 0 & 0 & 0 & 0 & $\bullet$ & 0 & $\bullet$ & 0 & $\bullet$ & $\bullet$ & $\bullet$ \\
\hline \multirow{2}{*}{$\begin{array}{l}\text { Russian } \\
\text { Federation }\end{array}$} & ECED & $\bullet$ & $\bullet$ & $\bullet$ & - & $\bullet$ & $\bullet$ & $\bullet$ & O & $\bullet$ & $\bullet$ & $\bullet$ & $\bullet$ & $\bullet$ & O & $\bullet$ & $\bullet$ & $\bullet$ & $\bullet$ \\
\hline & PPE & $\bullet$ & $\bullet$ & $\bullet$ & - & $\bullet$ & $\bullet$ & $\bullet$ & O & $\bullet$ & $\bullet$ & $\bullet$ & $\bullet$ & $\bullet$ & O & $\bullet$ & $\bullet$ & $\bullet$ & $\bullet$ \\
\hline \multirow[t]{2}{*}{ United States } & ECED & $\bullet$ & 0 & $\bullet$ & - & $\bullet$ & $\bullet$ & O & $\bullet$ & $\bullet$ & $\bullet$ & 0 & $\bullet$ & $\bullet$ & 0 & $\bullet$ & $\bullet$ & $\bullet$ & $\bullet$ \\
\hline & PPE & $\bullet$ & 0 & • & • & • & $\bullet$ & 0 & $\bullet$ & $\bullet$ & $\bullet$ & 0 & $\bullet$ & $\bullet$ & 0 & • & $\bullet$ & $\bullet$ & $\bullet$ \\
\hline
\end{tabular}

Key:

- Yes, regulation responsibility exists.

No, regulation responsibility does not exist.

- No data provided.

\section{Country specific notes:}

a In Denmark, pedagogues are licensed according to the standard of the bachelor degree. There are different levels of education. Some staff are assistants. Those are licensed at a national level. There are national standards, but municipalities decide how many staff of each profession they hire.

b In Denmark, for equal opportunities for staffing, group size, child:staff ratios and opening hours, no regulatory responsibility exists. Decisions are made at the subnational level, and decisions are not regulated. 
and Estonia reporting less regulation, and Italy and Denmark reporting higher levels of regulation.

There are a wide range of aspects of service delivery that are regulated in the study countries (see list on p. 82), with the most frequently reported regulated aspects of ECE settings across countries overall being health and safety, and child protection, and the least frequently reported regulated aspects across countries being setting opening hours and ECE curriculum programs. At the ECED level, the most frequently reported regulated aspects are health and safety, staff qualifications and training, child protection, and quality assurance. The most frequently reported regulated aspects at the PPE level in the study countries are financing, health and safety, environmental requirements, child protection, quality assurance, and reporting and accountability. In short, the evidence shows that a wide range of aspects of ECE service delivery are regulated in the study countries, which suggests a desire to ensure all ECE settings meet a set of minimal standards.

The complexity in the regulation system in some of the study countries is evident when information about the compliance bodies for each aspect of the regulations at national and subnational level are described. For example, in Chile, compliance bodies for ECED and PPE at a national level include the Superintendence of Educación, JUNJI (National Board), the Quality Agency and the Ministry of Education, the Ministry of Social Development, the Controloría General de la República, and at the subnational level they include the Municipality of each council, the Superintendence of Educación, the Controloría General de la República, the Ministry of Education, JUNJI and the Fundación Integra. Chile also pointed out that not all the regulatory requirements are compulsory for all kinds of providers, and not all providers are monitored by the same body, as the provider and the type of accreditation determine the compliance monitoring body.

In the Czech Republic, it is a simpler system, with responsibility for regulation compliance for PPE residing mainly with the Ministry of Education, and with some aspects being monitored by the Ministry of Labor and Social Affairs and the Ministry of Health.

In Italy, there are again a range of bodies at national, regional and municipality levels with regulatory compliance responsibility for ECED and PPE. Generally, regulations exist nationally and have regional and local articulation, with monitoring of the aspects mostly delegated to compliance bodies at the local level. The difference between ECED and PPE is that PPE is recognized as the first level of the education system and so is more centrally regulated and monitored. Another main difference is that ECED does not have a national curriculum and inspection body, while at PPE level these are well established within the education system. Differential situations also apply for monitoring state, municipal and private schools or schools with equal state status, with school inspectors generally monitoring state and private schools, while the municipal schools tend to have a local monitoring body.

In Poland, at ECED and PPE level regulation compliance is less complex, usually the responsibility of the mayor or president of the town, city or village, with some aspects being subject to monitoring by the Ministry of Labor and Social Policy, and the Ministry of Health. 
In the Russian Federation, there is a mix of national (federal), regional and local bodies who are responsible for regulation compliance for ECED and PPE, including the Federal Service for the Supervision of Education and Science, the Federal Ministry of Labor and Social Protection, the Rospoterbnadzor (federal level), the Ombudsman for Children, the Regional Obrnadzor and the Regional Ministry of Education.

\section{Summary Finding 22}

All study countries regulate their ECE services, with regulatory responsibilities being distributed between national and subnational bodies, indicating a desire to ensure all ECE services meet minimal standards. Some countries appear to regulate more than others, and some aspects of service delivery are more regulated than others, with the most frequently reported regulated aspects across countries overall being health and safety, and child protection. The system for monitoring regulatory compliance may also be very complex, with a wide range of national and subnational bodies with compliance responsibility for different aspects of regulation in many of the study countries.

\section{Staff Qualifications, Training and Remuneration}

There is research evidence that stimulating early learning environments are fostered by better qualified practitioners who can provide pedagogies that facilitate better learning outcomes for children (OECD, 2012b, 2013; Pascal \& Bertram, 2012; Sylva et al., 2008). This evidence indicates that a well-trained early childhood workforce, with high levels of qualification and access to ongoing professional development, is vital to ensuring high quality ECE for all children, and, in particular, for settings that serve children from poorer homes and their peers, if the achievement gap is to be closed. It appears that qualified staff provide children with more curricula-related activities (especially in language and mathematics) and encourage children to engage in challenging play. Montie, Xiang, and Schweinhart (2006) also suggested that teachers with more education use more words and more complex language when communicating with children. The presence of well-educated professional staff who use extended vocabulary and replicate what well-educated mothers can do has also been shown to be crucially important in improving school readiness. In addition, less-qualified staff have been shown to be better at supporting learning when they work with qualified teachers (Montie et al. 2006). Research has also consistently identified strong leadership as a key element of effective early childhood provision and so form part of a developing workforce strategy (Barnett, 2012; Muijs, Aubrey, Harris, \& Briggs, 2004; Rodd, 2005).

International studies have shown that there is considerable variation across countries in the extent of training and qualifications required for ECE staff. Professional development and training ranges from compulsory and fully funded, to voluntary, with no funding provided (EIU, 2012; OECD, 2013; Pascal, \& Bertram, 2012). In Europe, two models have been identified. In the most common model, there are two distinct paths of training: one for staff dealing with the youngest children (under three years) and one for the pre-primary sector (children aged three to six years). Other countries have a single training route and a professional profile for all educational staff across the whole ECE phase, where both management and staff tend to be more highly trained (Eurydice, 2009, European Commission/EACEA/Eurydice/Eurostat, 2014; Oberhuemer, 2005; 
OECD, 2012b). In a split system there may be a variety of staffing and training models across different types of provider (such as public or private) (Oberhuemer, 2005).

There are several different professional profiles or "core competencies" operating within ECE, which can be either a "teaching profile," a "socio-pedagogical profile" or a "caring or health profile" (Van Laere, Peeters, \& Vandenbroeck, 2012). There is still a tendency to allocate "educational" work to qualified staff, and "care" to less qualified staff, which can lead to a lack of continuity in the individual child's care and education (European Commission, 2011). This is exemplified in European countries by the hierarchy between core practitioners, who are often treated and conceptualized as respected professionals and paid accordingly, and assistants, who are viewed as low status workers, and often paid considerably less (Van Laere et al., 2012). This is not the case in Finland, for example, where "The ECEC (Early Childhood Education and Care) team constitutes a multi-professional community where tasks are not distributed on the basis of qualifications" (Eurydice, 2009, p. 116). Van Laere et al. (2012) argued that the "care" aspects of ECE should be valued more than they currently are, in order for a conception of ECE incorporating a broad range of aspects of child development to take hold.

Given the extensive evidential base for the importance of a qualified, well trained and appropriately remunerated early childhood workforce, the ECES investigated the most commonly found staff and leadership categories (those who work directly with children to support learning and development) at different stages in the ECE system, the minimal level of final qualification required, the opportunities for ongoing continuing professional development (CPD) and the average level of annual remuneration (annually in US\$) for these staff and leaders in the eight study countries. This information reveals a complex pattern of qualifications, training opportunities, and salary remuneration levels both within and between the study countries (Tables 19a-19k).

\section{CHILE}

In Chile (Table 19a), there are two main categories of staff who work to support children's learning and development, and two main categories of leader in services for children under the age of three (ECED). In settings for three- to six-year-olds (PPE), there are also two main categories of staff who work to support children's learning and development and three main categories of leader.

Early childhood teacher or educadora de párvulo: work with children at both ECED level and PPE level in Chile, have the same level of qualification (ISCED Level 5), have optional CPD opportunities, and receive the same annual salary of US\$10,000-US\$ 20,000, whether they work with older or younger ECE children. These teachers may also work in a leadership capacity in ECED and PPE settings.

Early childhood teacher assistant or técnico asistente del educador de párvulo: work with children at both ECED level and PPE level in Chile, have the same level of qualification (ISCED Level 3), have optional CPD opportunities, and receive the same annual salary of US\$5000-US\$10,000, whether they work with older or younger ECE children.

Pedagogical advisor or jefe de la unidad técnico pedagógica: work in PPE settings to lead the pedagogic practice in ECE settings. They have an ISCED Level 5 qualification, optional CPD opportunities, and receive an annual salary of US\$20,000-US\$30,000. 
Table 19a: Main staff and leader categories, minimum qualification level, continuing professional development (CPD) opportunities, and average annual remuneration level in US\$ of staff who work in services for children aged 0-3 years (ECED) and children aged 3 to the start of primary school (PPE) in Chile

\begin{tabular}{|c|c|c|c|c|c|c|}
\hline Level & $\begin{array}{l}\text { Staff/ } \\
\text { leader }\end{array}$ & $\begin{array}{l}\text { Staff/leader } \\
\text { category }\end{array}$ & $\begin{array}{c}\text { Staff/leader } \\
\text { category in } \\
\text { national language }\end{array}$ & $\begin{array}{c}\text { Minimum level } \\
\text { of final } \\
\text { qualification }\end{array}$ & $\begin{array}{l}\text { Requirements } \\
\text { for CPD }\end{array}$ & $\begin{array}{c}\text { Annual salary } \\
\text { range (US\$) }\end{array}$ \\
\hline \multirow{4}{*}{ ECED } & \multirow[b]{2}{*}{ Staff } & $\begin{array}{l}\text { Early childhood } \\
\text { teacher }\end{array}$ & $\begin{array}{l}\text { Educadora de } \\
\text { párvulo }\end{array}$ & ISCED 5 & Optional & 10,000 to $<20,000$ \\
\hline & & $\begin{array}{l}\text { Early childhood } \\
\text { teacher assistant }\end{array}$ & $\begin{array}{l}\text { Técnico asistente } \\
\text { del educador de } \\
\text { párvulo }\end{array}$ & ISCED 3 & Optional & 5000 to $<10,000$ \\
\hline & \multirow[t]{2}{*}{ Leader } & $\begin{array}{l}\text { Early childhood } \\
\text { teacher }\end{array}$ & $\begin{array}{l}\text { Educadora de } \\
\text { párvulo }\end{array}$ & ISCED 5 & Optional & 10,000 to $<20,000$ \\
\hline & & Director & Directora & ISCED 5 & Optional & 20,000 to $<30,000$ \\
\hline \multirow{5}{*}{ PPE } & \multirow[b]{2}{*}{ Staff } & $\begin{array}{l}\text { Early childhood } \\
\text { teacher }\end{array}$ & $\begin{array}{l}\text { Educadora de } \\
\text { párvulo }\end{array}$ & ISCED 5 & Optional & 10,000 to $<20,000$ \\
\hline & & $\begin{array}{l}\text { Early childhood } \\
\text { teacher assistant }\end{array}$ & $\begin{array}{l}\text { Técnico asistente } \\
\text { del educador de } \\
\text { párvulo }\end{array}$ & ISCED 3 & Optional & 5000 to $<10,000$ \\
\hline & \multirow{3}{*}{ Leader } & $\begin{array}{l}\text { Early childhood } \\
\text { teacher }\end{array}$ & $\begin{array}{l}\text { Educadora de } \\
\text { párvulos }\end{array}$ & ISCED 5 & Optional & 10,000 to $<20,000$ \\
\hline & & Pedagogical advisor & $\begin{array}{l}\text { Jefe de la unidad } \\
\text { técnico pedagógica }\end{array}$ & ISCED 5 & Optional & 20,000 to $<30,000$ \\
\hline & & Principal & Director & ISCED 5 & Optional & 20,000 to $<30,000$ \\
\hline
\end{tabular}

Director or principal: lead and manage ECE settings at ECED and PPE level. They have an ISCED Level 5 qualification, optional CPD opportunities, and receive an annual salary of US $\$ 20,000-$ US $\$ 30,000$.

In Chile, staff and leaders working in ECE settings have the same minimum qualifications, training opportunities and salary, whether they work in ECED settings or PPE settings. Senior staff members working directly with children are educated to first stage tertiary level (Level 5), assistant staff to upper secondary school level (Level 3) and leaders to first stage tertiary level (Level 5). However, it is noted that these requirements are only compulsory for settings with public funding and private settings that have a certificate from JUNJI or the Ministry of Education.

Managers or directors of settings serving three- to four-year-old children should have a four-year Bachelor degree and every setting must have this role designated, but they can also fulfil the teacher function in the classroom alongside their leadership role. 


\section{CZECH REPUBLIC}

The Czech Republic was not able to submit data for ECED because of the implementation of current reforms. There are two main categories of staff who work to support children's learning and development in settings that serve children from three to six years, and one category of leader (Table 19b).

Table 19b: Main staff and leader categories, minimum qualification level, continuing professional development (CPD) opportunities and average annual remuneration level in US\$ of staff who work in services for children aged 3 to the start of primary school (PPE) in Czech Republic

\begin{tabular}{l|l|l|l|c|c|c}
\hline \multirow{2}{*}{ Level } & $\begin{array}{c}\text { Staff/ } \\
\text { leader }\end{array}$ & \multicolumn{1}{|c|}{$\begin{array}{c}\text { Staff/leader } \\
\text { category }\end{array}$} & $\begin{array}{c}\text { Staff/leader } \\
\text { category in } \\
\text { national language }\end{array}$ & $\begin{array}{c}\text { Minimum level } \\
\text { of final } \\
\text { qualification }\end{array}$ & $\begin{array}{c}\text { Requirements } \\
\text { for CPD }\end{array}$ & $\begin{array}{c}\text { Annual salary } \\
\text { range (US\$) }\end{array}$ \\
\hline \multirow{3}{*}{ PPE } & \multirow{2}{*}{ Staff } & Teacher & Učitel & ISCED 3 & Optional & 10,000 to $<20,000$ \\
\cline { 2 - 7 } & Leacher assistant & Asistent pedagoga & ISCED 2 & Optional & 5000 to $<10,000$ \\
\cline { 2 - 7 } & Leader & Head teacher & Reditel & ISCED 3 & Required & 10,000 to $<20,000$ \\
\hline
\end{tabular}

Teacher or učitel: work with three- to six-year-old children. They are required to have an ISCED Level 3 qualification, have optional CPD opportunities, and earn an annual salary of US $\$ 10,000-$ US $\$ 20,000$.

Teacher assistant or asistent pedagoga: work with three- to six-year-old children. They are required to have an ISCED Level 2 qualification, have optional CPD opportunities, and earn an annual salary of US\$5000-US\$10,000.

Head teacher or ředitel: has responsibility to lead and manage PPE settings. They are required to have an ISCED Level 3 qualification, are required to undertake CPD, and receive an annual salary of US\$10,000-US\$ 20,000.

The Czech Republic reported that a new law has given all schools the status of independent legal entities, with a high degree of autonomy and also greater responsibilities. Head teachers have full responsibility for quality and efficiency of the educational process, adjustment of educational programs, financial management of the school, appointment and dismissal of teachers, and relationships with the community and public. Currently, teachers are trained to Bachelor's level (ISCED Level 5) and head teachers are trained to Master's level (ISCED Level 6). In ECED settings, before the current reforms, pre-primary teachers in a nursery school were trained to ISCED Level $3 \mathrm{~A}$ in a shortened study program. They were also expected to hold a school leaving examination certificate. 


\section{DENMARK}

In Denmark, there are four main categories of staff who work to support children's learning and development in both ECED and PPE settings (Table 19c). There is one category of leader for both ECED and PPE settings.

Table 19c: Main staff and leader categories, minimum qualification level, continuing professional Development (CPD) opportunities and average annual remuneration level in US\$ of staff who work in services for children aged 0-3 years (ECED) and children aged 3 to the start of primary school (PPE) in Denmark

\begin{tabular}{|c|c|c|c|c|c|c|}
\hline Level & $\begin{array}{l}\text { Staff/ } \\
\text { leader }\end{array}$ & $\begin{array}{l}\text { Staff/leader } \\
\text { category }\end{array}$ & $\begin{array}{c}\text { Staff/leader } \\
\text { category in } \\
\text { national language }\end{array}$ & $\begin{array}{l}\text { Minimum level } \\
\text { of final } \\
\text { qualification }\end{array}$ & $\begin{array}{l}\text { Requirements } \\
\text { for CPD }\end{array}$ & $\begin{array}{l}\text { Annual salary } \\
\text { range (US\$) }\end{array}$ \\
\hline \multirow{4}{*}{ ECED } & \multirow{3}{*}{ Staff } & Pedagogues & Pædagoger & ISCED 5 & Optional & 30,000 to $<50,000$ \\
\hline & & $\begin{array}{l}\text { Semi-trained } \\
\text { assistant } \\
\text { pedagogues }\end{array}$ & $\begin{array}{l}\text { Medhiælpere med } \\
\text { pædagogisk } \\
\text { grunduddannelse } \\
\text { (PGU) }\end{array}$ & ISCED 2 & Optional & 20,000 to $<30,000$ \\
\hline & & $\begin{array}{l}\text { Assistant } \\
\text { pedagogues } \\
\text { (untrained) }\end{array}$ & Medhjælpere & $\begin{array}{c}\text { No formal } \\
\text { qualification required }\end{array}$ & Optional & 20,000 to $<30,000$ \\
\hline & Leader & Manager & Leder & ISCED 5 & Optional & 30,000 to $<50,000$ \\
\hline \multirow{4}{*}{ PPE } & \multirow{3}{*}{ Staff } & Pedagogues & Pædagoger & ISCED 5 & Optional & 30,000 to $<50,000$ \\
\hline & & $\begin{array}{l}\text { Semi-trained } \\
\text { assistant } \\
\text { pedagogues }\end{array}$ & $\begin{array}{l}\text { Medhjælpere med } \\
\text { pædagogisk } \\
\text { grunduddannelse } \\
\text { (PGU) }\end{array}$ & ISCED 2 & Optional & 20,000 to $<30,000$ \\
\hline & & $\begin{array}{l}\text { Assistant } \\
\text { pedagogues } \\
\text { (untrained) }\end{array}$ & Medhjælpere & $\begin{array}{c}\text { No formal } \\
\text { qualification required }\end{array}$ & Optional & 20,000 to $<30,000$ \\
\hline & Leader & Manager & Leder & ISCED 5 & Optional & 30,000 to $<50,000$ \\
\hline
\end{tabular}

Pedagogue or Padagoger: work with children at both ECED level and PPE level in Denmark, have the same level of qualification (ISCED Level 5), have optional CPD opportunities, and receive the same annual salary of US\$30,000-US\$50,000, whether they work with older or younger ECE children. These teachers may also work in a leadership capacity in ECED and PPE settings.

There is also a category of Pedagogue who work in PPE settings, but for whom no formal qualification is required. These staff have access to optional CPD opportunities, and earn less than formally qualified staff (US\$20,000-US\$30,000 per year).

Semi-trained assistant pedagogue: or Medhjolpere med padagogisk grunduddannelse (PGU) also work with children at both ECED level and PPE level in Denmark, have the same level of qualification (ISCED Level 2), have optional CPD opportunities, and receive the same annual salary of US\$20,000-US\$30,000, whether they work with older or younger ECE children.

Manager or Leder: has responsibility to lead and manage ECE settings at ECED and PPE level. They have an ISCED Level 5 qualification, optional CPD opportunities, and receive an annual salary of US\$ 30,000-US\$ 50,000. 
In Denmark, staff and leaders working in ECE settings have the same minimum qualifications, training opportunities and salary whether they work in ECED settings or PPE settings. Senior staff working directly with children are educated to post-secondary non-tertiary education (Level 4), assistant staff to lower secondary school level (Level 2 ), and leaders to post-secondary non-tertiary education (Level 4). Pedagogues have a three-and-a-half year Bachelor degree and assistant pedagogues have a one-anda-half year training. Usually $60-100 \%$ of staff in a setting are pedagogues. Assistant pedagogues are not allowed to be managers.

\section{ESTONIA}

In Estonia there are three main categories of staff who work to support children's learning and development and two main categories of leader in services for underthrees (ECED). In services for three- to seven-year-olds (PPE), there are two main categories of staff who work to support children's learning and development and two categories of leader (Table 19d).

Table 19d: Main staff and leader categories, minimum qualification level, continuing professional development (CPD) opportunities, and average annual remuneration level in US\$ of staff who work in services for children aged 0-3 years (ECED) and children aged 3 to the start of primary school (PPE) in Estonia

\begin{tabular}{|c|c|c|c|c|c|c|}
\hline Level & $\begin{array}{l}\text { Staff/ } \\
\text { leader }\end{array}$ & $\begin{array}{l}\text { Staff/leader } \\
\text { category }\end{array}$ & $\begin{array}{c}\text { Staff/leader } \\
\text { category in } \\
\text { national language }\end{array}$ & $\begin{array}{l}\text { Minimum level } \\
\text { of final } \\
\text { qualification }\end{array}$ & $\begin{array}{l}\text { Requirements } \\
\text { for CPD }\end{array}$ & $\begin{array}{l}\text { Annual salary } \\
\text { range (US\$) }\end{array}$ \\
\hline \multirow{5}{*}{ ECED } & \multirow{3}{*}{ Staff } & Teacher & Õpetaja & ISCED 5 & Required & 5000 to $<10,000$ \\
\hline & & Assistant & Õpetaja abi & ISCED 3 & Optional & 1000 to $<5000$ \\
\hline & & Nurse & Lapsehoidja & ISCED 4 & Optional & 1000 to $<5000$ \\
\hline & \multirow[t]{2}{*}{ Leader } & Director & Direktor & ISCED 5 & Required & 10,000 to $<20,000$ \\
\hline & & Head teacher & Õppealajuhataja & ISCED 5 & Required & 10,000 to $<20,000$ \\
\hline \multirow{4}{*}{ PPE } & \multirow{2}{*}{ Staff } & Teacher & Õpetaja & ISCED 5 & Required & 5000 to $<10,000$ \\
\hline & & Assistant & Õpetaja abi & ISCED 3 & Optional & 1000 to $<5000$ \\
\hline & \multirow[t]{2}{*}{ Leader } & Director & Direktor & ISCED 5 & Required & 10,000 to $<20,000$ \\
\hline & & Head teacher & Õppealajuhataja & ISCED 5 & Required & 10,000 to $<20,000$ \\
\hline
\end{tabular}

Teacher or Opetaja: work with children under the age of three (ECED level) and with three- to seven-year-olds (PPE) and are qualified to ISCED Level 5. They are required to undertake CPD, and have an annual salary of US $\$ 5000-$ US $\$ 10,000$.

Assistant or Oppetaja abi: work with children at ECED and PPE level. They have an ISCED Level 3 qualification, optional CPD opportunities, and have an annual salary of up to US\$ 5000 .

Nurse or Lapsehoidja: work with children at ECED level. They have an ISCED Level 4 qualification, have optional CPD opportunities, and an annual salary of up to US\$ 5000 .

Director or Direktor: has responsibility to lead and manage ECE settings at ECED and PPE level. They are required to have an ISCED Level 5 qualification in pedagogy, are required to undertake CPD, and receive an annual salary of US\$10,000-US\$20,000. 
Head Teacher or Oppealajuhataja: has responsibility to lead and manage PPE settings. They are required to have an ISCED Level 5 qualification in pedagogy, are required to undertake CPD, and receive an annual salary of US\$10,000-US\$20,000.

In Estonia, teaching staff, assistants and leaders working in ECE settings have the same minimum qualifications, training opportunities and salary whether they work with younger children or with older children. Senior staff working directly with children are educated to first stage tertiary level (Level 5), assistant staff to upper secondary school level (Level 3), and leaders to post-secondary non-tertiary education (Level 5).

\section{ITALY}

It should be noted that the situation represented in this evidence for Italy is changing, due to the education system reform introduced by Italian Law 107 of July 2015. One key element included in Law 107 is the provision of further legislation for the reunification of the split system, in order to establish an integrated or unitary ISCED Level 0 system serving children from birth to six years. Within the foreseen legislation, most aspects reported are under consideration for further changes, including staff categorization in ECED and their qualifications. National contracts for staff and leadership are also under revision, and they might affect aspects in many ways. Another example of planned change is the provision for leaders of professional development and training, which it is foreseen to be mandatory at least on the topic of social inclusion. Nevertheless, effort has been made to specify the most up-to-date information and incorporate planned changes whenever possible (Table 19e).

In Italy there are currently three main categories of staff who work to support children's learning and development in services for under-threes (ECED) and two categories in services for three to six-year-olds (PPE). There are four main categories of leader, three of whom work in ECED and PPE services, and one that works only in PPE settings (Table 19e).

Nursery school educator or Educatore asilo nido /micro nido work with children under the age of three years (ECED). They are required to have an ISCED Level 3 qualification and have optional CPD opportunities. Salaries currently vary according to local and national contracts.

Nursery school educators/teacher aide or Ausiliari asili nido: work with children at ECED level. They are not required to have a formal qualification and have optional CPD opportunities. Salaries currently vary according to local and national contracts.

Paediatric nurse or Puericultrici: generally work with children under the age of three (ECED), with a more health-oriented profile, and they can also work in private preschools. They are required to have an ISCED Level 2 qualification and have optional CPD opportunities. Salaries currently vary according to local and national contracts.

Preschool school teacher or Docente di scuola dell'infanzia (also called Maestra): work with three- to six-year-old children (PPE). They are required to have an ISCED Level 5 qualification (with some exceptions) and have optional CPD. Teachers in state schools are an exception: they now will have mandatory CPD, while, up until now, mandatory training was required only in their first year of service. CPD is provided face-to-face and online via a national platform. In state preschools they have an annual average salary of US\$ 34,162 . 
Preschool teacher aide or Assistenti scuola dell'infanzia: work with three- to six-yearold children (PPE) in private schools only. They are not required to have a formal qualification and have optional CPD opportunities. Salaries currently vary according to local and national contracts.

Provincial or regional coordinator of early childhood education services or Coordinatore provinciale o regionale dei servizi per l'infanzia: has responsibility to lead the development of private ECE services (ECED and PPE) at regional or provincial level. They are required to have an ISCED Level 5 qualification. Salaries currently vary according to local and national contracts.

Coordinator of early childhood education services or Coordinatore educativo nei servizi per l'infanzia: has responsibility to lead and coordinate private ECE services (ECED and PPE) at a local level. They are required to have an ISCED Level 5 qualification. In 13 out of 21 regions and autonomous provinces salaries currently vary according to local and national contracts.

Lead teacher in early childhood education services or Coordinatore-docente: leads pedagogic practice in private settings either for birth to three-year-olds (ECED) or for three- to six-year-olds (PPE). When in PPE, they can also work in state comprehensive institutes, under the school leader. They are generally required to have an ISCED Level 3 qualification. Salaries currently vary according to local and national contracts, yet in state preschools they have an average annual salary of US\$34,162 and could earn more depending on their years of experience.

School leader of state comprehensive institutes (that include PPE) or Dirigenti scolastici di istituti comprensivi: leads and manages state comprehensive institutions where PPE is included. They are required to have an ISCED Level 5 qualification. They have an annual salary of over US\$50,000.

In Italy, staff working in ECE differ in settings that serve under-threes (ECED) and settings that serve three to six-year-olds (PPE). At ECED Level the senior staff is likely to be less qualified than the senior staff working in PPE settings (Level 3 or upper secondary school level compared with Level 5 or first stage tertiary level). Teacher aides or assistants in ECED and PPE non-state settings are not required to have a formal qualification. Those in leadership positions are usually expected to have a Level 5 or first stage tertiary level qualification. Teachers and head teachers in state schools receive mandatory CPD during their first year of service, after which it becomes optional, yet this situation is expected to change. For teachers, CPD is already mandatory according to the new reform of 2015, and it should become mandatory for leaders as well, according to future regulations on the reunification of Italy's ECE system. There is little information about CPD in Italy because it is optional, although the National Training Agency provides courses. Remuneration arrangements were being revised in 2014, with new national contracts under negotiation.

It should be noted that, in Italy, although the law prescribes teachers of state schools should have an ISCED Level 5 or a five-year tertiary degree, local regulations still allow municipalities and private providers to hire teacher aides with a minimum qualification of ISCED Level 2 plus an additional qualification, and preschool teachers at ISCED Level 3. It is reported that such derogations to the national regulations have considerably slowed down the upgrading of PPE teachers' qualifications. However, the new system reform makes provision to change this situation. 
Table 19e: Main staff and leader categories, minimum qualification level, continuing professional development (CPD) opportunities, and average annual remuneration level in US\$ of staff who work in services for children aged 0-3 years (ECED) and children aged 3 to the start of primary school (PPE) in Italy

\begin{tabular}{|c|c|c|c|c|c|c|}
\hline Level & $\begin{array}{l}\text { Staff/ } \\
\text { leader }\end{array}$ & $\begin{array}{l}\text { Staff/leader } \\
\text { category }\end{array}$ & $\begin{array}{c}\text { Staff/leader } \\
\text { category in } \\
\text { national language }\end{array}$ & $\begin{array}{l}\text { Minimum level } \\
\text { of final } \\
\text { qualification }\end{array}$ & $\begin{array}{l}\text { Requirements } \\
\text { for CPD }\end{array}$ & $\begin{array}{l}\text { Annual salary } \\
\text { range }(U S \$)^{c, d}\end{array}$ \\
\hline \multirow{6}{*}{ ECED } & \multirow{3}{*}{ Staff } & $\begin{array}{l}\text { Educator in nursery } \\
\text { schools }\end{array}$ & $\begin{array}{l}\text { Educatore asilo } \\
\text { nido /micro nido }\end{array}$ & ISCED 3 & Optional & - \\
\hline & & Pediatric nurse & Puericultrici & ISCED 2 & Optional & - \\
\hline & & $\begin{array}{l}\text { Educator/teacher } \\
\text { aide in nursery } \\
\text { schools }\end{array}$ & Ausiliari asili nido & $\begin{array}{c}\text { No formal } \\
\text { qualification required }\end{array}$ & Optional & - \\
\hline & \multirow{3}{*}{ Leader } & $\begin{array}{l}\text { Provincial or regional } \\
\text { coordinator of early } \\
\text { childhood education } \\
\text { services }\end{array}$ & $\begin{array}{l}\text { Coordinatore } \\
\text { provinciale o } \\
\text { regionale dei } \\
\text { servizi per l'infanzia }\end{array}$ & ISCED 5 & Optional & - \\
\hline & & $\begin{array}{l}\text { Coordinator of early } \\
\text { childhood education } \\
\text { services }\end{array}$ & $\begin{array}{l}\text { Coordinatore } \\
\text { educativo nei } \\
\text { servizi per l'infanzia }\end{array}$ & ISCED $5^{a}$ & Optional & - \\
\hline & & $\begin{array}{l}\text { Lead teacher in early } \\
\text { childhood education } \\
\text { services }\end{array}$ & $\begin{array}{l}\text { Coordinatore- } \\
\text { docente }\end{array}$ & ISCED 3 & Optional & - \\
\hline \multirow{6}{*}{ PPE } & \multirow[t]{2}{*}{ Staff } & Preschool teacher & $\begin{array}{l}\text { Docente di scuola } \\
\text { dell'infanzia (also } \\
\text { called Maestra) }\end{array}$ & ISCED $5^{b}$ & Optionale $^{\mathrm{e}}$ & - \\
\hline & & $\begin{array}{l}\text { Preschool teacher } \\
\text { aide }^{a}\end{array}$ & $\begin{array}{l}\text { Assistenti scuola } \\
\text { dell'infanzia }\end{array}$ & $\begin{array}{c}\text { No formal } \\
\text { qualification required }\end{array}$ & Optional & - \\
\hline & \multirow{4}{*}{ Leader } & $\begin{array}{l}\text { Provincial or regional } \\
\text { coordinator of early } \\
\text { childhood education } \\
\text { services }\end{array}$ & $\begin{array}{l}\text { Coordinatore } \\
\text { provinciale o } \\
\text { regionale diservizi } \\
\text { per l'infanzia }\end{array}$ & ISCED 5 & Mandatory & - \\
\hline & & $\begin{array}{l}\text { Coordinator of early } \\
\text { childhood education } \\
\text { services }\end{array}$ & $\begin{array}{l}\text { Coordinatore } \\
\text { educativo nei } \\
\text { servizi per l'infanzia }\end{array}$ & ISCED 5 & Optional & - \\
\hline & & $\begin{array}{l}\text { Lead teacher in early } \\
\text { childhood education } \\
\text { services }\end{array}$ & $\begin{array}{l}\text { Coordinatore- } \\
\text { docente }\end{array}$ & ISCED 3 & Optional & - \\
\hline & & $\begin{array}{l}\text { School Leader of } \\
\text { State comprehensive } \\
\text { institutes (that } \\
\text { include PPE) }\end{array}$ & $\begin{array}{l}\text { Dirigenti scolastici } \\
\text { di istituti } \\
\text { comprensivi }\end{array}$ & ISCED 5 & Optional ${ }^{9}$ & 50,000 or more \\
\hline
\end{tabular}

Key:

- No data provided.

\section{Country specific notes:}

a In Italy, there is no national regulation concerning minimum qualifications for ECED personnel. Only 13 out of the 21 regions and autonomous provinces require ECED leaders to have Level 5 qualifications. This aspect is expected to change with the future legislation announced by the reform of Law 107/2015, and minimum qualification should be set at university degree level.

b Since 1990, the law prescribes that teachers of state schools have an ISCED 5 degree, however, local regulations still allow municipalities and private providers to hire teacher aides with a minimum qualification at ISCED level 2 plus specific training and ISCED 3 for preschool teachers. In private schools and in schools with equal status, the minimum qualification level is ISCED 3 , because teachers do not need to pass the ability examination. Such derogations to national regulations have considerably slowed down the upgrading of skills of PPE teachers, given their slow turnover, especially in private schools, municipal schools and in schools with equal state status. This aspect is also expected to change for PPE, with the future legislation announced by the reform of Law 107/2015, and minimum qualification should be set at university degree level. 
Country specific notes (contd.)

c In Italy, for PPE, data are provided for state school contracts only. For private, non-state schools with equal status (paritarie) and non-state municipal schools, other contracts apply that cannot be easily compared; thus they are excluded from this analysis. In addition, national contracts for non-state preschools are currently under revision.

d No comparable data are available for the 0-2 segment. There are several contracts applied at the local level, and thus it is very difficult to determine an average. In addition, national contracts are currently under revision.

e In the first year of service, teachers and leaders of state schools currently receive mandatory training.

f In private schools only.

${ }^{g}$ This leadership category only applies to state schools, while the other categories apply to private schools or schools with equal status. A leader of a state comprehensive institute might appoint a lead teacher coordinating all preschool teachers in that school. Continued professional development for leaders in state comprehensive institutes is changing from optional to mandatory, at least for certain topics such as social inclusion: Law 107/2015 is making provision for this type of training for leaders in the future.

It was also stated by the NRC that in Italian ECED settings, the role of leader is not well defined and designation can vary from region to region. This means there is little national documentation of leadership categories. Although the presence of a Coordinator of Early Childhood Services is often cited in accreditation procedures as a quality element, it is reported by the NRC that little information has been documented about staff with this profile in Italy. This aspect should also be changing with the new system reform.

\section{POLAND}

In Poland, there are six main categories of staff who work to support children's learning and development, and two main categories of leader in settings for under-threes (ECED). In settings for three- to six-year-olds (PPE) there are two main categories of staff who work to support children's learning and development and one main category of leader. Minimum professional qualifications, training and the remuneration levels of these staff and leaders vary among settings (Table 19f).

Child carer or Opiekunka dziecięca: work with children under the age of three (ECED), are required to have an ISCED Level 3 qualification, have optional CPD opportunities, and receive an annual salary of between US\$1000 and US\$ 5000 .

Teacher or Nauczyciele: work with children under the age of three (ECED) or from three to six years (PPE). They have the same level of qualification (ISCED Level 5) regardless of the age phase they work with, and have optional CPD opportunities, but the salary they receive differs significantly with setting. Teachers who work in ECED settings receive an annual salary of US\$ 1000 to US\$ 5000, whereas teachers who work in PPE settings receive an annual salary of US\$ 5000 to US\$10,000.

Nurse or Pielegniarki: work with children under the age of three years (ECED). They are required to have an ISCED Level 4 qualification, are required to undertake CPD, and receive an annual salary of US\$1000 to US\$ 5000 .

Childbirth assistant or Połozne: work with under-threes (ECED) and are required to have an ISCED Level 4 qualification, are required to undertake CPD, and have an annual salary of US\$1000 to US\$5000.

Doctor or Lekarze: work in an ECED setting, are required to undertake CPD, and have an annual salary of US\$1000 to US\$ 5000 .

Volunteers or Wolontariusz: work in ECED settings. There are no training requirements and there is no remuneration. 
Table 19f: Main staff and leader categories, minimum qualification level, continuing professional development (CPD) opportunities and average annual remuneration level in US\$ of staff who work in services for children aged 0-3 years (ECED) and children aged 3 to the start of primary school (PPE) in Poland

\begin{tabular}{|c|c|c|c|c|c|c|}
\hline Level & $\begin{array}{l}\text { Staff/ } \\
\text { leader }\end{array}$ & $\begin{array}{l}\text { Staff/leader } \\
\text { category }\end{array}$ & $\begin{array}{c}\text { Staff/leader } \\
\text { category in } \\
\text { national language }\end{array}$ & $\begin{array}{c}\text { Minimum level } \\
\text { of final } \\
\text { qualification }\end{array}$ & $\begin{array}{l}\text { Requirements } \\
\text { for CPD }\end{array}$ & $\begin{array}{l}\text { Annual salary } \\
\text { range (US\$) }\end{array}$ \\
\hline \multirow{8}{*}{ ECED } & \multirow{7}{*}{ Staff } & Child carers & Opiekunka Dziecięca & ISCED 3 & Optional & 1000 to $<5000$ \\
\hline & & Other child carers & Inni Opiekunowie & ISCED 3 & Optional & 1000 to $<5000$ \\
\hline & & Teachers & Nauczyciele & ISCED 5 & Optional & 1000 to $<5000$ \\
\hline & & Nurses & Pielęgniarki & ISCED 4 & Required & 1000 to $<5000$ \\
\hline & & Childbirth assistants & Położne & ISCED 4 & Required & 1000 to $<5000$ \\
\hline & & Doctors & Lekarze & ISCED 5 & Required & 1000 to $<5000$ \\
\hline & & Volunteers & Wolontariusz & - & - & - \\
\hline & Leader & Principal & Dyrektor & ISCED 3 & Optional & 5000 to $<10,000$ \\
\hline \multirow{3}{*}{ PPE } & \multirow{2}{*}{ Staff } & Teacher & Nauczyciel & ISCED 5 & Optional & 5000 to $<10,000$ \\
\hline & & Auxiliary staff & Personel pomocniczy & ISCED 3 & Unavailable & 5000 to $<10,000$ \\
\hline & Leader & Principal & Dyrektor & ISCED 5 & Optional & 5000 to $<10,000$ \\
\hline
\end{tabular}

Key:

- No data provided.

\section{Country specific notes:}

In Poland it should be noted that the occupational allowance (the variable part of the salary given for the type of responsibility undertaken, career progression, cost of living, or other variable factors) is not easy to establish from the contractual arrangements; it has thus been excluded here, and figures are based only on the basic salary for newly-hired staff. ECED contracts often differentiate between different levels of leaders or even include leader categories; thus leaders' salaries appear to be quite similar to those of ECED staff and do not vary greatly from one contract to another.

Auxiliary staff or Personel pomocniczy: work in PPE settings with children from three to six years of age. They are required to have an ISCED Level 3 qualification, but there is no CPD program currently available. They receive an annual salary of US\$ 5000 to US\$ 10,000 .

Principal or Dyrektor: leads and manages either an ECED or a PPE setting. In ECED settings they are required to have an ISCED Level 3 qualification, have optional CPD opportunities and receive an annual salary of US\$ 1000 to US\$ 5000. In PPE settings they are required to have an ISCED Level 5 qualification, have optional CPD opportunities and receive an annual salary of US\$ 5000 to US\$ 10,000 .

Staff working in ECE in Poland differ in settings that serve under-threes (ECED) and settings that serve three to six-year-olds (PPE). For ECED and PPE settings, senior staff have a minimum Level 5 or first stage tertiary level qualification and assistant staff have a minimum Level 3 or upper secondary school level qualification. Health-oriented staff can be qualified at Level 4 or 5, and are required to undertake CPD. The setting leaders (principals) have to have higher qualifications if they work in PPE settings and may earn significantly more.

In Poland, it is noted that there is no national regulation concerning minimal qualifications for ECED personnel. Regional regulations apply and it was reported by the NRC that sometimes these are dated. It is also possible that teachers and pediatric nurses hold no higher than an ISCED Level 2 vocational qualification and no formal qualification is required for teacher aides. For leaders at PPE level, there is an expectation 
that they have an ISCED Level 5 qualification and also five years of experience as a teacher, with good performance, no criminal record and appropriate management training (business management or management in education).

\section{THE RUSSIAN FEDERATION}

The Russian Federation has eight main categories of staff who work to support children's learning and development and three main categories of leader in both ECED and PPE settings (Table 19g). The Russian Federation NRC was able to provide only limited information on CPD opportunities and annual salary levels for staff and leaders.

Educator or Воспитатель, старший воспитатель: work in settings with children under the age of three (ECED) and in settings with children from three to seven years (PPE). They are required to have an ISCED Level 4 qualification and also to undertake CPD for ECED settings, but CPD is optional for PPE settings. They receive an annual salary of US\$1000 to US\$5000.

Educator assistant or Помощник воспитателя: work in settings with children under the age of three (ECED) and in settings with children from three to seven years (PPE). They are required to have an ISCED Level 3 qualification and also to undertake CPD for ECED settings, but this is optional for PPE settings.

Junior educator or Помощник воспитателя: work in settings with children under the age of three (ECED) and in settings with children from three to seven years (PPE). They are required to have an ISCED Level 4 qualification. CPD is optional for ECED settings, and is unavailable for PPE settings.

Methodist or Методист: work in settings with children under the age of three (ECED) and in settings with children from three to seven years (PPE). They are required to have an ISCED Level 6 qualification and CPD is optional.

Speech therapist teacher or Учитель-дефектолог, учитель-логопед: work in settings with children under the age of three (ECED) and in settings with children from three to seven years (PPE). They are required to have an ISCED Level 6 qualification and also to undertake CPD for ECED settings, but this is optional for PPE settings.

Psychologist or Педагог-психолог: work in settings with children under the age of three (ECED) and in settings with children from three to seven years (PPE). They are required to have an ISCED Level 4 qualification and also to undertake CPD for ECED settings, but this is optional for PPE settings.

Music teacher or Музыкальный руководитель: work in settings with children under the age of three (ECED) and in settings with children from three to seven years (PPE). They are required to have an ISCED Level 4 qualification and also to undertake CPD for ECED settings, but this is optional for PPE settings.

Physical development teacher or Инструктор по физической культуре: work in settings with children under the age of three (ECED) and in settings with children from three to seven years (PPE). They are required to have an ISCED Level 4 qualification and also to undertake CPD for ECED settings, but this is optional for PPE settings.

Head or Руководитель ДОУ: leads and manages either an ECED or a PPE setting. They are required to have an ISCED Level 6 qualification.

Deputy head or Заместитель руководителя ДОУ: leads and manages either an ECED or a PPE setting. They are required to have an ISCED Level 6 qualification. 
Table 19g: Main staff and leader categories, minimum qualification level, continuing professional development (CPD) opportunities and average annual remuneration level in US\$ of staff who work in services for children aged 0-3 years (ECED) and children aged 3 to the start of primary school (PPE) in the Russian Federation

\begin{tabular}{|c|c|c|c|c|c|c|}
\hline Level & $\begin{array}{l}\text { Staff/ } \\
\text { leader }\end{array}$ & $\begin{array}{l}\text { Staff/leader } \\
\text { category }\end{array}$ & $\begin{array}{c}\text { Staff/leader } \\
\text { category in } \\
\text { national language }\end{array}$ & $\begin{array}{c}\text { Minimum level } \\
\text { of final } \\
\text { qualification }\end{array}$ & $\begin{array}{l}\text { Requirements } \\
\text { for CPD }\end{array}$ & $\begin{array}{l}\text { Annual salary } \\
\text { range (US\$) }\end{array}$ \\
\hline \multirow{11}{*}{ ECED } & \multirow{8}{*}{ Staff } & Educator & $\begin{array}{l}\text { Воспитатель } \\
\text { старший } \\
\text { воспитатель }\end{array}$ & ISCED 4 & Required & see explanatory notes \\
\hline & & Educator assistant & $\begin{array}{l}\text { Помощник } \\
\text { воспитателя }\end{array}$ & ISCED 3 & Required & - \\
\hline & & Junior educator & $\begin{array}{l}\text { Младший } \\
\text { воспитатель }\end{array}$ & ISCED 4 & Optional & - \\
\hline & & Methodist & Методист & ISCED 6 & Required & - \\
\hline & & $\begin{array}{l}\text { Speech therapist } \\
\text { teacher }\end{array}$ & $\begin{array}{l}\text { Учитель - } \\
\text { дефектологу, } \\
\text { читель - логопед }\end{array}$ & ISCED 6 & Required & - \\
\hline & & Psychologist & Педагог-психолог & ISCED 4 & Required & - \\
\hline & & Music teacher & $\begin{array}{l}\text { Музыкальный } \\
\text { руководитель }\end{array}$ & ISCED 4 & Required & - \\
\hline & & $\begin{array}{l}\text { Physical development } \\
\text { teacher }\end{array}$ & $\begin{array}{l}\text { Инструктор по } \\
\text { физической } \\
\text { культуре }\end{array}$ & ISCED 4 & Required & - \\
\hline & \multirow{3}{*}{ Leader } & Head & $\begin{array}{l}\text { Руководитель } \\
\text { ДОу }\end{array}$ & ISCED 6 & - & - \\
\hline & & Deputy head & $\begin{array}{l}\text { Заместитель } \\
\text { руководителя доу }\end{array}$ & ISCED 6 & - & - \\
\hline & & Head of department & $\begin{array}{l}\text { Руководитель } \\
\text { структурно } \\
\text { гоподразделени } \\
\text { я ДОу }\end{array}$ & ISCED 6 & - & - \\
\hline
\end{tabular}

(Contined on next page)

Head of department or Руководитель структурного подразделения ДОУ: leads and manages a department in either an ECED or a PPE setting. They are required to have an ISCED Level 6 qualification.

In the Russian Federation, there is a single qualification handbook for managers, professional and employees working in ECE published under a decree of the Ministry of Health and Social Development. There is also federal state law on education setting out qualification requirements. These documents specify that all staff and leaders at ECED or PPE level should have minimum qualifications; qualification requirements do not differ for staff who work with younger or older children, but staff have differential access to CPD opportunities between these two phases. Senior staff working directly with children and leaders are usually educated to graduate level (Level 6), and assistant staff and health-based staff are generally educated to a post-secondary non-tertiary education level (Level 4). Leaders are also required to have at least five years of work experience in teaching positions. 


\begin{tabular}{|c|c|c|c|c|c|c|}
\hline Level & $\begin{array}{l}\text { Staff/ } \\
\text { leader }\end{array}$ & $\begin{array}{l}\text { Staff/leader } \\
\text { category }\end{array}$ & $\begin{array}{c}\text { Staff/leader } \\
\text { category in } \\
\text { national language }\end{array}$ & $\begin{array}{l}\text { Minimum level } \\
\text { of final } \\
\text { qualification }\end{array}$ & $\begin{array}{l}\text { Requirements } \\
\text { for CPD }\end{array}$ & $\begin{array}{l}\text { Annual salary } \\
\text { range (US\$) }\end{array}$ \\
\hline \multirow{11}{*}{ PPE } & \multirow{8}{*}{ Staff } & Educator & $\begin{array}{l}\text { Воспитатель } \\
\text { старший } \\
\text { воспитатель }\end{array}$ & ISCED 4 & Required & see explanatory notes \\
\hline & & Educator assistant & $\begin{array}{l}\text { Помощник } \\
\text { воспитателя }\end{array}$ & ISCED 3 & Required & - \\
\hline & & Junior educator & $\begin{array}{l}\text { Младший } \\
\text { воспитатель }\end{array}$ & ISCED 4 & Optional & - \\
\hline & & Methodist & Методист & ISCED 6 & Required & - \\
\hline & & $\begin{array}{l}\text { Speech therapist } \\
\text { teacher }\end{array}$ & $\begin{array}{l}\text { учитель - } \\
\text { дефектологу, } \\
\text { читель - логопед }\end{array}$ & ISCED 6 & Required & - \\
\hline & & Psychologist & Педагог-психолог & ISCED 4 & Required & - \\
\hline & & Music teacher & $\begin{array}{l}\text { Музыкальный } \\
\text { руководитель }\end{array}$ & ISCED 4 & Required & - \\
\hline & & $\begin{array}{l}\text { Physical development } \\
\text { teacher }\end{array}$ & $\begin{array}{l}\text { Инструктор по } \\
\text { физической } \\
\text { культуре }\end{array}$ & ISCED 4 & Required & - \\
\hline & \multirow{3}{*}{ Leader } & Head & $\begin{array}{l}\text { Руководитель } \\
\text { ДОу }\end{array}$ & ISCED 6 & - & - \\
\hline & & Deputy head & $\begin{array}{l}\text { Заместитель } \\
\text { руководителя доу }\end{array}$ & ISCED 6 & - & - \\
\hline & & Head of department & $\begin{array}{l}\text { Руководитель } \\
\text { структурно } \\
\text { гоподразделени } \\
\text { tдоу }\end{array}$ & ISCED 6 & - & - \\
\hline
\end{tabular}

Key:

- No data provided.

\section{Explanatory notes:}

In the Russian Federation, the remuneration rates are given as an average of salaries of all types of pedagogic staff.

Minimum regional average salary rate: US\$2700.

Maximum regional average salary rate: US\$14,100

Modal regional average salary rate: US\$3600-4800 (40\% of regions).

Median regional average salary rate: US $\$ 5000$.

The combination of staff working in a setting depends on the curriculum program that is developed by the setting. The NRC reported that the most common staffing for one group of children (as defined by floor space available) is to have two educators, one full-time junior educator or educator assistant, a part-time (0.25) music teacher, a part-time (0.125) physical development teacher, a part-time (0.075) psychologist, and one full-time speech therapist. 


\section{THE UNITED STATES}

The United States NRC reported there were six main categories of staff who work to support children's learning and development, and two main categories of leader in both ECED and PPE settings (Table 19h).

Lead teacher: work in center-based (not school-based) settings with children under the age of three (ECED) and children aged from three to six (PPE). There may or may not be a formal qualification requirement based on setting or funding source (additional information on education is provided below in Tables 19i and 19j); lead teachers have optional CPD opportunities and receive an annual salary of US\$20,000 to US\$30,000.

Teacher: work in center-based (not school-based) settings with children under the age of three (ECED) and in settings with children aged three to six (PPE). There may or may not be a formal qualification requirement based on setting or funding source (additional information on education is provided below in Tables 19i and 19j); teachers have optional CPD opportunities and receive an annual salary of US\$20,000 to US\$ 30,000 .

Assistant teachers: work in center-based settings (not school-based) with children under the age of three (ECED) and in settings with children aged from three to six (PPE). There may or may not be a formal qualification requirement based on setting or funding source (additional information on education is provided below in Tables $19 \mathrm{i}$ and 19j); assistant teachers have optional CPD opportunities and receive an annual salary of US $\$ 20,000$ to US\$30,000.

Aides: work in center-based (not school-based) settings with children under the age of three (ECED) and children aged from three to six (PPE). There may or may not be a formal qualification requirement based on setting or funding source (additional information on education is provided below in Table 19i and 19j); aides have optional CPD opportunities and receive an annual salary of US\$10,000 to US\$30,000.

Listed providers: work in home-based settings with children under the age of three (ECED) and in settings with children aged from three to six (PPE). There is no formal qualification requirement (additional information on education is provided below in Tables 19i and 19j); listed providers have optional CPD opportunities, and receive an annual salary of US $\$ 30,000$ to US $\$ 50,000$.

Unlisted providers: work in home-based settings with children under the age of three (ECED) and in settings with children aged from three to six (PPE). There is no formal qualification requirement (additional information on education is provided below in Tables 19i and 19j); unlisted providers have optional CPD opportunities and receive an annual salary of US\$5000 to US\$20,000.

Kindergarten teacher: work with five- to six-year-old children in either public or private kindergarten classes. They are required to have an ISCED Level 5 qualification (additional information on education is provided below in Tables 19i and 19j), and to undertake CPD. They receive an annual salary of US\$50,000 plus in public kindergartens, and US\$ 30,000 to US\$50,000 in private kindergartens.

Directors and other leaders without the title director: have responsibility to lead and manage settings at ECED and PPE level. They are required to have an ISCED Level 6 qualification and have optional CPD opportunities. They receive an annual salary of US\$ 30,000 to US $\$ 50,000$. 
Table 19h: Main staff and leader categories, minimum qualification level, continuing professional development (CPD) opportunities and average annual remuneration level in US\$ of staff who work in services for children aged 0-3 years (ECED) and children aged 3 to the start of primary school (PPE) in the United States

\begin{tabular}{|c|c|c|c|c|c|}
\hline Level & $\begin{array}{l}\text { Staff/ } \\
\text { leader }\end{array}$ & $\begin{array}{l}\text { Staff/leader } \\
\text { category }\end{array}$ & $\begin{array}{c}\text { Minimum level of final } \\
\text { qualification }{ }^{c}\end{array}$ & $\begin{array}{l}\text { Requirements } \\
\text { for CPD }\end{array}$ & $\begin{array}{l}\text { Annual salary } \\
\text { range (US\$) }\end{array}$ \\
\hline \multirow{8}{*}{ ECED $^{a}$} & \multirow{6}{*}{ Staff } & Center-based, lead teachers & No formal qualification required & Optional & 20,000 to $<30,000$ \\
\hline & & Center-based, teachers & No formal qualification required & Optional & 20,000 to $<30,000$ \\
\hline & & $\begin{array}{l}\text { Center-based, } \\
\text { assistant teachers }\end{array}$ & No formal qualification required & Optional & 20,000 to $<30,000$ \\
\hline & & Center-based, aides & No formal qualification required & Optional & 20,000 to $<30,000$ \\
\hline & & Home-based, listed providers ${ }^{b}$ & No formal qualification required & Optional & 30,000 to $<50,000$ \\
\hline & & $\begin{array}{l}\text { Home-based, unlisted } \\
\text { providers, paid }\end{array}$ & No formal qualification required & Optional & 5000 to $<10,000$ \\
\hline & \multirow[b]{2}{*}{ Leader } & Directors & No formal qualification required & Optional & 30,000 to $<50,000$ \\
\hline & & $\begin{array}{l}\text { Other leaders (not entitled } \\
\text { "director") }\end{array}$ & No formal qualification required & Optional & 30,000 to $<50,000$ \\
\hline \multirow{12}{*}{ PPE } & \multirow{8}{*}{ Staff } & Center-based, lead teachers & No formal qualification required & Optional & 20,000 to $<30,000$ \\
\hline & & Center-based, teachers & No formal qualification required & Optional & 20,000 to $<30,000$ \\
\hline & & $\begin{array}{l}\text { Center-based, assistant } \\
\text { teachers }\end{array}$ & No formal qualification required & Optional & 20,000 to $<30,000$ \\
\hline & & Center-based, aides & No formal qualification required & Optional & 10,000 to $<20,000$ \\
\hline & & Home-based, listed providers ${ }^{b}$ & No formal qualification required & Optional & 30,000 to $<50,000$ \\
\hline & & $\begin{array}{l}\text { Home-based, unlisted } \\
\text { providers, paid }^{\text {b }}\end{array}$ & No formal qualification required & Optional & 10,000 to $<20,000$ \\
\hline & & Kindergarten teacher, public & ISCED 5 & Required & 50,000 or more \\
\hline & & Kindergarten teacher, private & ISCED 5 & Required & 30,000 to $<50,000$ \\
\hline & \multirow{4}{*}{ Leader } & Directors & No formal qualification required & Optional & 30,000 to $<50,000$ \\
\hline & & $\begin{array}{l}\text { Other leaders without the } \\
\text { title "director" }\end{array}$ & No formal qualification required & Optional & 30,000 to $<50,000$ \\
\hline & & School principal, public & ISCED 5 & Optional & 50,000 or more \\
\hline & & School principal, private & ISCED 5 & Optional & 50,000 or more \\
\hline
\end{tabular}

\section{Explanatory notes:}

a For staff who work in ECED settings, qualification requirements vary. There are specific setting types within the broader category "centerbased" that require certain levels of education. For example, Early Head Start/Head Start, state preschool and primary school based programs have differing education requirements for different levels of staff. However, there is no uniform requirement across all of the different kinds of center-based settings within the US center-based day care centers, preschools or prekindergarten programs that are not in a private home. Therefore, the United States provided data that shows the distribution of the highest educational level attained by staff type.

b Data sources for staff categories for children aged 0 to not-yet-in-kindergarten are from the US Department of Health and Human Services, National Survey of Early Care and Education (NSECE) Project Team (NSECE, 2012). For the NSECE, the provider sampling frame built from administrative lists was used to sample listed providers, including center-based programs and home-based ECE providers. Listed providers were primarily licensed or regulated family day care providers, but included other formally listed home-based providers such as license-exempt providers or providers participating in Early Head Start. Alternatively, as part of a screener interview sent to households, the respondent to the screener could provide information on whether an adult in the household provided care to children not their own for at least five hours per week in a home-based setting. These households were identified as "unlisted home-based" and were subsequently surveyed with an unlisted home-based provider survey (detail provided by the NRC).

c For the USA, ISCED Level 5 appears to encompass an associate's degree through to a master's degree, and within the USA, there is significant distinction between an associate's, to a bachelor's, to a master's degree, captured by the program number within the ISCED level. (See Tables $19 \mathrm{i}$ and $19 \mathrm{j}$ for further information on the distribution of education.)

d Home-based salaries were calculated as average weekly revenue multiplied by 52 weeks to convert to average annual salary. The US Department of Health and Human Services (NSECE, 2012) provided salary data for center-based and home-based staff. The US Department of Education, National Center for Education Statistics, Schools and Staffing Survey (SASS) 2011-2012 (SASS 2012) provided the salary data for kindergarten teachers and school principals. 
School principals have responsibility to lead and manage public or private settings at PPE level. They have an ISCED Level 5 qualification (additional information on education is provided below in Tables 19i and 19j), have optional CPD opportunities and receive an annual salary of US\$ 50,000 plus.

Staff and leaders working in ECE settings in the United States appear to have the same training opportunities and salary whether they work in ECED settings or PPE settings (Table 19h), but these data mask considerable variation across setting types and age phases. There are no formal qualifications required in the United States for most settings offering services to children from birth to kindergarten age (other than those that are part of state preschool programs or federal programs such as Head Start, Title I or Preschool Development Grants) and this masks considerable variations between setting types and age phases. However, staff and leaders who work in kindergartens and schools are required to have an ISCED Level 6 qualification, and must undertake CPD.

For staff who work with under-threes (ECED), qualifications vary significantly between center-based and home-based services (Table 19i).

Table 19i: Distribution of educational attainment for staff who work in settings that serve children birth to three years in the United States

\begin{tabular}{l|c|c|c|c}
\hline \multirow{2}{*}{$\begin{array}{l}\text { Staff categories that serve children } \\
\text { birth to three years }\end{array}$} & High school or less & $\begin{array}{c}\text { Some college, } \\
\text { no degree }\end{array}$ & Associate's degree & $\begin{array}{c}\text { Bachelor's degree } \\
\text { or higher }\end{array}$ \\
\cline { 2 - 5 } Center-based, lead teachers & 23.4 & 30.5 & 18.8 & 27.3 \\
\hline Center-based, teachers & 27.4 & 36.1 & 15.2 & 21.3 \\
\hline Center-based, assistant teachers & 29.4 & 35.4 & 17.7 & 17.5 \\
\hline Center-based, aides & 34.8 & 40.7 & 7.5 & 17.0 \\
\hline Home-based provider, listed & 33.8 & 34.7 & 16.0 & 15.4 \\
\hline Home-based provider, unlisted, paid & 50.7 & 26.6 & 8.3 & 14.3 \\
\hline
\end{tabular}

Source:

US Department of Health and Human Services, Administration for Children and Families (NSECE, 2012).

These data reveal that center-based services for under-threes tend to have more highly educated staff than home-based services, and that less than half of lead teachers and teachers in center-based services have an ISCED Level 5 qualification.

For staff who work with three to not-yet-in-kindergarten (PPE), qualifications also vary between center-based and home-based services (Table 19j).

These data show that staff educational attainment levels appear to be higher in centerbased settings serving older children and lower in home-based settings. The educational attainment levels of teachers in primary school appear on average to be higher than those of providers in center-based or home-based settings (Table 19k).

Opportunities for CPD for ECE staff differ state by state, and depend on the program and age phase. For example, at ECED level, early Head Start teachers are required to attend no less than 15 hours of professional development per year. Some states have no requirements for prekindergarten programs, while others are more stringent; for example, Missouri requires 12 hours of professional development per year and an 
Table 19j: Distribution of educational attainment for staff who work in settings that serve children three years to not-yet-in-kindergarten in the United States

\begin{tabular}{l|c|c|c|c}
\hline \multirow{2}{*}{$\begin{array}{l}\text { Staff categories that serve children } \\
\text { three years to not-yet-in-kindergarten }\end{array}$} & High school or less & $\begin{array}{c}\text { Some college, } \\
\text { no degree }\end{array}$ & Associate's degree & $\begin{array}{c}\text { Bachelor's degree } \\
\text { or higher }\end{array}$ \\
\cline { 2 - 5 } & 11.0 & 19.1 & 16.8 & 53.2 \\
\hline Center-based, lead teachers & 9.7 & 16.9 & 18.2 & 55.2 \\
\hline Center-based, teachers & 19.0 & 33.0 & 22.0 & 26.0 \\
\hline Center-based, assistant teachers & 24.3 & 36.0 & 11.3 & 28.4 \\
\hline Center-based, aides & 33.7 & 34.7 & 16.0 & 15.6 \\
\hline Home-based provider, listed & 55.4 & 22.0 & 8.6 & 14.0 \\
\hline Home-based provider, unlisted, paid & & & & \\
\hline
\end{tabular}

Source:

US Department of Health and Human Services, Administration for Children and Families (NSECE, 2012).

Table 19k: Qualifications of staff who work as teachers in private and public primary schools in the United States

\begin{tabular}{l|c|c}
\hline Level of qualification & $\begin{array}{c}\text { \% Teachers in public } \\
\text { primary schools }\end{array}$ & $\begin{array}{c}\text { \% Teachers in private } \\
\text { primary schools }\end{array}$ \\
\hline No bachelor's degree & 3.2 & 8.4 \\
\hline Bachelor's degree & 41.2 & 52.8 \\
\hline Master's degree & 47.3 & 32.7 \\
\hline Higher than master's degree & 8.4 & 6.1 \\
\hline
\end{tabular}

Source:

US Department of Education, National Center for Education Statistics, 2011-2012 (SASS 2012).

additional 30 hours for first-year teachers and assistants (source: http://www.nieer.org/ resources/factsheets/2.pdf). At PPE level, the requirements continue to vary by state, but professional development credits are required for renewal of a teacher's license. In addition, Head Start teachers are required to attend no less than 15 hours of professional development per year.

Qualification requirements for leaders at both ECED level and PPE level are again variable in the United States and differ between setting types, age phases and states. However, in the United States leaders have higher levels of education than other staff, particularly in school- based settings, and settings serving older children. In more detail, in settings serving under-threes, 59.0\% of directors have a bachelor's degree or higher, and at PPE level, that rises to $80.5 \%$. In K-12 private schools, $69 \%$ have a master's degree or above, and in K-12 public schools, $91.4 \%$ hold this advanced qualification. For leaders professional development is usually optional. 


\section{Summary Finding 23}

The study countries illustrate the diversity of staffing of ECE services, which varies by age phase, type of setting, setting provider (public or private), location, and professional role of staff. Services for under-threes (ECED) indicate that while there is a wide range of staffing options within the study countries, there are more "education" focused staff than "care" or "health" focused staff. In the United States, staff working in settings outside primary schools tend to have greater preparation in child development, while teachers in primary schools often have more training in academic teaching. The qualification levels of these staff also range from lower secondary school level to graduate level, and include, but not always, specialized training in ECE. The minimum qualification required of staff tends to increase with the age of the children they work with, with more staff having ISCED Level 5 and above in the pre-primary (kindergarten) year. Leaders in all settings are usually required to have an ISCED Level 5 or above in educational attainment to work with the pre-primary year. Specific training in leadership and management is rare.

\section{Summary Finding 24}

Opportunities for continuing professional development are variable in the study countries. This is optional for most staff working at the ECED level, becoming a requirement for more senior staff or for those who work with the pre-primary year.

\section{Summary Finding 25}

Remuneration rates are very different between the study countries, although within country salary levels are usually higher for staff in PPE level settings than those in ECED settings. In the study countries, staff with higher qualifications and more senior roles are more highly paid, and those who work in public settings are paid more than those who work in private settings, as are those working in center-based services as compared to those working in home-based services. There is also a differentiation between those who work with children aged from three to six or seven years (PPE) and those who work with children under three years (ECED); this holds even for teachers within these age groups, depending on funding sources. Leaders' basic salaries do not always differ from those of the staff who work directly with children, but in some cases they may receive additional allowances, enabling them to earn considerably more than other staff. 


\section{Group Size and Ratios}

Studies have shown that group size affects staff working conditions and can influence the satisfaction of professionals with their workplace, which, in turn, is likely to affect the ability and willingness of professionals to provide stable relationships and attentive interactions with children (OECD, 2012b). High staff turnover disrupts the continuity of care, negates professional development efforts, harms overall quality, and negatively affects child outcomes. Barnett et al. (2015) stated in their NIEER report that "in sum, preschool research strongly indicates that smaller class sizes are associated with greater educational effectiveness and other benefits" and that "even within studies that focus only on preschool children, the effects of class size have been found to be larger for younger children."

There is also some evidence (OECD, 2010; Pascal et al., 2012; Sylva et al., 2008) that a favorable staff:child ratio (i.e. one where there are fewer children for every adult) in early education programs, particularly those working with less advantaged children, is helpful in ensuring the quality of interactions between educators and children (Howes, Philips, \& Whitebrook, 1992). However, there is little definitive evidence on the relationship of different ratios on outcomes for children. A study by Pascal et al. (2012) showed that, for European countries, the range of staff:child ratios for preschool classes ranged from 1:22 in France to 1:6 in Sweden. The countries examined in the Pascal et al. (2012) study indicated a consistent association between these ratios and student performance in PISA rankings, with those countries with fewer children per adult performing better. Favorable ratios may help to create a climate of emotional security, allowing practitioners to be more responsive to children, being more readily able to support them when they have needs or are in distress. In the absence of direct measures of the quality of provision, the ratio of pupils to teaching staff is often used as a proxy to measure quality in ECE (OECD, 2010). A large body of research has found that the fewer children to staff, the better the children perform in cognitive (mathematics and science) and linguistic (language, reading and word recognition) assessments (Corak et al., 2012; OECD, 2010). There is no definitive research that indicates optimal staff:child ratios at different ages, as work so far has been unable to disentangle the effects of staff qualification, group size and ratios. While the available literature on the effects of staff:child ratios cannot offer an exact "best" ratio, there was a general consensus in a UNICEF (United Nations Children's Fund) report (Bennett, 2008) that an acceptable model for ECE classes for four- and five-year-olds would be a group of 22-24 children with two adults, assuming that both have qualifications related to working with young children in an ECE setting. For example, in the US, the Departments of Education and Health and Human Services' Preschool Development Grants program require programs to have a minimum staff:child ratio of 1:10 with a class size of no larger than 20 children (note that class size is not the same as a staff:child ratio). For Head Start, a maximum staff:child ratio of 1:10 with class sizes of fewer than 20 children is required; Early Head Start staff ratios are 1:4, with group sizes are limited to eight children. It should be noted that to support a pedagogy with more sustained shared dialogues between adults and children, beneficial to underachieving children, requires smaller group sizes as well as more favorable staff:child ratios.

The ECES collected information on the existence of national regulations on group size and staff:child ratios for differing age groups of children in the study countries. 


\section{Group size}

Seven of the study countries indicated that they had national or subnational regulations on group size, but these were differently specified (Table 20). Poland did not have national or subnational regulation on group sizes. In five countries, (Chile, the Czech Republic, Denmark, Estonia, and the United States) maximum group sizes were specified according to the age of the child. In Italy's ECED, group size recommendations were set at regional level according to the type of service offered and the type of teacher contract. According to the new regulations announced within the 2015 education system reform, this aspect should be subject to change. In the Russian Federation, group size was determined by the available floor space in a center.

Table 20: Regulated group size for children aged 0-3 years (ECED) and children aged 3 to the start of primary school (PPE)

\begin{tabular}{|c|c|c|c|c|c|c|c|}
\hline \multirow[b]{2}{*}{ Country } & \multicolumn{7}{|c|}{ Maximum group size for children aged... } \\
\hline & $\begin{array}{c}\text { Under } 1 \text { year } \\
\text { old }\end{array}$ & 1 year old & 2 years old & 3 years old & 4 years old & 5 years old & 6 years old \\
\hline Chile & 42 & 42 & 32 & 32 & 35 & 45 & $\diamond$ \\
\hline Czech Republic & $\mathrm{n} / \mathrm{a}$ & $\mathrm{n} / \mathrm{a}$ & $\mathrm{n} / \mathrm{a}$ & $24-28$ & $24-28$ & $24-28$ & $24-28$ \\
\hline Denmark & $-{ }^{a}$ & $10-14^{b}$ & $10-14^{b}$ & $20-25^{b}$ & $20-25$ & $20-25$ & $\diamond$ \\
\hline Estonia & $-{ }^{a}$ & $14-16$ & $14-16$ & $20-24$ & $20-24$ & $20-24$ & $20-24$ \\
\hline Italy & $-{ }^{c}$ & $-{ }^{c}$ & $-{ }^{c}$ & $18-26^{d}$ & $18-26^{d}$ & $18-26^{d}$ & $\diamond$ \\
\hline Poland & $\mathrm{n} / \mathrm{a}$ & $\mathrm{n} / \mathrm{a}$ & $\mathrm{n} / \mathrm{a}$ & $\mathrm{n} / \mathrm{a}$ & $\mathrm{n} / \mathrm{a}$ & $\mathrm{n} / \mathrm{a}$ & $\diamond$ \\
\hline Russian Federation & $-{ }^{e}$ & $-{ }^{e}$ & $-{ }^{e}$ & $-{ }^{e}$ & $-{ }^{e}$ & $-{ }^{e}$ & $-{ }^{e}$ \\
\hline United States $^{f}$ & 8 & 12 & 12 & $17-18$ & 20 & 20 & $\diamond$ \\
\hline
\end{tabular}

Key:

n/a Not applicable as there are no national or typical subnational regulated group sizes.

$\diamond \quad$ Age phase is not applicable, as children are enrolled in school.

- Data in this format are not available.

\section{Country specific notes:}

a In Denmark and Estonia, most children under the age of one are at home with their parents and this means there are no recommended group sizes for center-based provision.

b In Denmark, these maximum sizes are recommended but not regulated.

c In Italy, ECED services (Asili nido and other integrated services) in the 0-3 age range are fragmented, since regional regulations generally apply, in addition to national contracts for teachers. The differentiation is not in terms of maximum group/class size, but rather on the maximum number of children per setting/center (ranging from as low as 10 in services organized within a family context to 75 maximum for Asili Nido and 60 for other integrated services). Also, the differentiation in terms of a staff:child ratio is not dependent on the age of children, but rather on the typology of center considered and the type of teacher contract. The new regulations announced within the 2015 education system reform should also affect this aspect.

d In Italy, in PPE in state schools, maximum group size is reduced to 20 if, in the classroom, there is a child with certified disabilities.

e In the Russian Federation, the number of children in a preschool group is determined by calculating the floor area of a group playroom, and is not based on a maximum group size per age of child.

$f$ In the United States, the majority of states with prekindergarten initiatives set class size and ratio requirements that are consistent with standards developed jointly by the American Public Health Association and the American Academy of Pediatrics and the National Association for the Education of Young Children.

In countries with national or subnational regulations, the largest group sizes are found in Chile, ranging from 32 for two-year-olds to 45 for five-year-olds. The smallest group sizes were in the United States, from a maximum of eight children in a group for birth to one-year-olds to 20 for four and five-year-olds. The data suggest that group sizes generally increase with the age of the child, with the exception of Chile, which reports children under two years old in a maximum group of 42, reducing to 32 for two- and three-year-olds and then increasing again to 45 for five-year-olds. 


\section{Staff:child ratios}

All of the study countries except Denmark (where local communities decide) indicated that they had national regulations or recommendations on staff:child ratios (Table 21). In Chile, the Czech Republic, Estonia, Poland and the United States, these are calculated according to the maximum number of children per staff member. In Italy, staff:child ratio recommendations are set at the regional level according to the type of service offered and the type of teacher contract. The 2015 education system reform will alter this situation. In the Russian Federation, the staff:child ratio is determined by the floor space available in a center. The data suggest that, in the majority of the study countries, the number of children per staff member increases as children get older from birth to three years, and then stabilizes from age three to primary school transfer age.

Table 21: Regulated staff:child ratios for children aged 0-3 years (ECED) and children aged 3 to the start of primary school (PPE)

\begin{tabular}{l|c|c|c|c|c|c|c}
\hline \multirow{2}{*}{ Country } & \multicolumn{7}{|c}{ Recommended staff:child ratio for children aged... } \\
\cline { 2 - 9 } & $\begin{array}{c}\text { Under 1 year } \\
\text { old }\end{array}$ & 1 year old & 2 years old & 3 years old & 4 years old & 5 years old & 6 years old \\
\hline Chile & $1: 6$ & $1: 6$ & $1: 13$ & $1: 16$ & $1: 18$ & $1: 23$ & $\diamond$ \\
\hline Czech Republic & $\mathrm{n} / \mathrm{a}$ & $\mathrm{n} / \mathrm{a}$ & $\mathrm{n} / \mathrm{a}$ & $1: 13$ & $1: 13$ & $1: 13$ & $1: 13$ \\
\hline Denmark & $-^{\mathrm{a}}$ & $\mathrm{n} / \mathrm{a}$ & $\mathrm{n} / \mathrm{a}$ & $\mathrm{n} / \mathrm{a}$ & $\mathrm{n} / \mathrm{a}$ & $\mathrm{n} / \mathrm{a}$ & $\diamond$ \\
\hline Estonia & $-^{\mathrm{a}}$ & $1: 7-8$ & $1: 7-8$ & $1: 12$ & $1: 12$ & $1: 12$ & $1: 12$ \\
\hline Italy & $-^{\mathrm{b}}$ & $-{ }^{\mathrm{b}}$ & $-{ }^{\mathrm{b}}$ & $-{ }^{\mathrm{b}}$ & $-^{\mathrm{b}}$ & $-^{\mathrm{b}}$ & $\diamond$ \\
\hline Russian Federation & $-{ }^{\mathrm{c}}$ & $-^{\mathrm{c}}$ & $-{ }^{\mathrm{c}}$ & $-{ }^{\mathrm{c}}$ & $-{ }^{\mathrm{c}}$ & $-^{\mathrm{c}}$ & $-^{\mathrm{c}}$ \\
\hline Poland & $1: 5$ & $1: 8$ & $1: 8$ & $1: 8$ & $1: 8$ & $-^{-}$ & $\diamond$ \\
\hline United States & $1: 4$ & $1: 4$ & $1: 10$ & $1: 10$ & $1: 10$ & $1: 10$ & $\diamond$ \\
\hline
\end{tabular}

Key:

n/a Not applicable as there are no national or typical subnational regulated staff:child ratios.

$\diamond \quad$ Age phase is not applicable, as children are enrolled in school.

Data in this format are not available.

Country specific notes:

a In Denmark and Estonia, most children under the age of one are at home with their parents, and so there are no set staff:child ratios for centerbased provision.

b In Italy, differentiation in terms of staff:child ratio is not only dependent on the age of the children, but also on the typology of the center and the type of teacher contract. The 2015 education system reform will alter this situation.

c In the Russian Federation, the staff:child ratio in preschool groups is determined by the floor area of a group playroom.

\section{Summary Finding 26}

All of the study countries regulate group sizes and staff:child ratios in their ECE services. Maximum group sizes change as the child gets older, with group size steadily increasing year on year, and the numbers of children per staff member also increases from birth to age three, and then stabilizes from age three years to entry to primary schooling. Regulated maximum levels for group size and adult:child ratios in the study countries do not vary significantly, with one exception (Chile), where group sizes are much larger, and there are more children per adult. 


\section{Health and Safety Measures}

International studies (OECD, 2012b; Pascal et al., 2012) suggest that a regulatory framework, with minimum health, safety and child protection standards can promote the health and safety of children and ensure minimum levels of quality. It is argued that national regulatory frameworks can "level the playing field" by ensuring all children benefit from a minimum standard of provision and regulated experiences to support a child's wider socio-emotional and physical well-being, which in turn provides the optimal conditions for children to learn and develop. However, there is little research evidence on this aspect of provision and outcomes for children.

The ECES collected information on the existence and scope of national health and safety regulations for different ages of children in the study countries (Table 22)

Table 22: Existence and scope of health and safety regulations for children aged 0-3 years (ECED) and children aged 3 to the start of primary school (PPE)

\begin{tabular}{|c|c|c|c|c|c|c|c|c|c|c|c|c|}
\hline \multirow[b]{2}{*}{ Country } & \multirow[b]{2}{*}{ Level } & \multicolumn{11}{|c|}{ Existence of specific regulations } \\
\hline & & 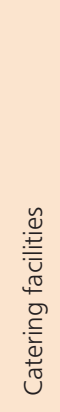 & 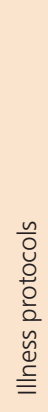 & 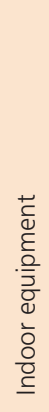 & 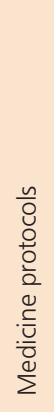 & 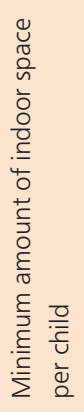 & 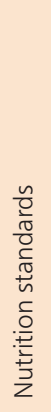 & 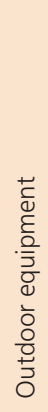 & 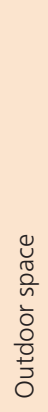 & 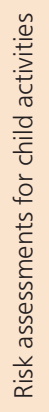 & 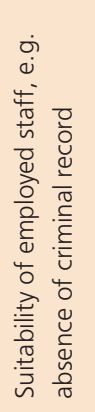 & 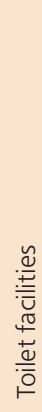 \\
\hline \multirow[t]{2}{*}{ Chile } & ECED & $\bullet$ & O & $\bullet$ & O & $\bullet$ & $\bullet$ & $\bullet$ & $\bullet$ & O & O & $\bullet$ \\
\hline & PPE & $\bullet$ & O & $\bullet$ & O & $\bullet$ & $\bullet$ & $\bullet$ & $\bullet$ & O & 0 & $\bullet$ \\
\hline \multirow[t]{2}{*}{ Czech Republic } & ECED & O & $\bullet$ & O & O & $\bullet$ & O & 0 & O & O & O & $\bullet$ \\
\hline & PPE & $\bullet$ & $\bullet$ & $\bullet$ & $\bullet$ & $\bullet$ & $\bullet$ & o & $\bullet$ & $\bullet$ & $\bullet$ & $\bullet$ \\
\hline \multirow[t]{2}{*}{ Denmark } & ECED & $\bullet$ & O & $\bullet$ & $\bullet$ & $\bullet$ & $\bullet$ & $\bullet$ & $\bullet$ & $\bullet$ & $\bullet$ & $\bullet$ \\
\hline & PPE & $\bullet$ & 0 & $\bullet$ & $\bullet$ & $\bullet$ & $\bullet$ & $\bullet$ & $\bullet$ & $\bullet$ & $\bullet$ & $\bullet$ \\
\hline \multirow[t]{2}{*}{ Estonia } & ECED & $\bullet$ & $\bullet$ & $\bullet$ & $\bullet$ & $\bullet$ & $\bullet$ & $\bullet$ & $\bullet$ & $\bullet$ & $\bullet$ & $\bullet$ \\
\hline & PPE & $\bullet$ & $\bullet$ & $\bullet$ & $\bullet$ & $\bullet$ & $\bullet$ & $\bullet$ & $\bullet$ & $\bullet$ & $\bullet$ & $\bullet$ \\
\hline \multirow[t]{2}{*}{ Italy } & ECED & $\bullet$ & $\bullet$ & 0 & $\bullet$ & $\bullet$ & $\bullet$ & 0 & - & 0 & $\bullet$ & • \\
\hline & PPE & $\bullet$ & $\bullet$ & $\bullet$ & $\bullet$ & $\bullet$ & $\bullet$ & 0 & $\bullet$ & 0 & $\bullet$ & $\bullet$ \\
\hline \multirow[t]{2}{*}{ Poland } & ECED & $\bullet$ & 0 & $\bullet$ & $\bullet$ & $\bullet$ & 0 & 0 & 0 & 0 & $\bullet$ & $\bullet$ \\
\hline & PPE & 0 & 0 & $\bullet$ & 0 & 0 & 0 & $\bullet$ & • & 0 & 0 & - \\
\hline \multirow{2}{*}{$\begin{array}{l}\text { Russian } \\
\text { Federation }\end{array}$} & ECED & $\bullet$ & $\bullet$ & $\bullet$ & $\bullet$ & $\bullet$ & $\bullet$ & $\bullet$ & $\bullet$ & 0 & $\bullet$ & $\bullet$ \\
\hline & PPE & $\bullet$ & $\bullet$ & $\bullet$ & $\bullet$ & $\bullet$ & $\bullet$ & $\bullet$ & • & 0 & $\bullet$ & $\bullet$ \\
\hline \multirow[t]{2}{*}{ United States } & ECED & $\bullet$ & $\bullet$ & $\bullet$ & $\bullet$ & $\bullet$ & $\bullet$ & $\bullet$ & $\bullet$ & $\bullet$ & • & $\bullet$ \\
\hline & PPE & $\bullet$ & $\bullet$ & $\bullet$ & $\bullet$ & $\bullet$ & $\bullet$ & $\bullet$ & $\bullet$ & $\bullet$ & • & $\bullet$ \\
\hline
\end{tabular}

Key:

- Yes, national regulation exists.

O No, national regulation does not exist. 
All the study countries indicated that they have national health and safety regulations for settings working with under-threes (ECED) and three-year-olds to primary school age (PPE). The most frequently reported regulated aspects of health and safety at both ECED and PPE level are the toilet facilities and the indoor space required for children. The least frequently reported aspects are the outdoor space and risk assessments for children's activities. In the majority of countries the same regulatory focus is evident at both levels, but in the Czech Republic there appears to be more aspects regulated at PPE level than at ECED level, and in Poland the focus varies. In many countries there are subnational regulations in addition to the national regulations.

\section{Summary Finding 27}

The importance of regulating for health and safety is acknowledged in all the study countries throughout the ISCED Level 0 age phases, with a wide range of aspects being addressed in the regulations, suggesting key concern for the health and wellbeing of the children.

\section{ECE Curriculum Guidance and Pedagogic Approaches}

The OECD (2013) refers to "curriculum" as the knowledge contents and methods that support children's learning and development. Questions such as "What to teach?" and "How to teach it?" (Barnett, Hustedt, Allison, Friedman, Stevenson Boyd, \& Ainsworth, 2007) raise complex issues in ECE containing multiple components, such as ECE goals, content and pedagogical practices (Litjens, \& Taguma, 2010). In the United States, for example, the term "early learning and development standards" is used and curricula are the materials, teachers' guides, and strategies linked to the standards. "Pedagogic approaches" refers to how teaching and learning is supported and facilitated by practitioners in a setting, and reflects the philosophies, values, theories, or concepts adopted in the setting to inform the teaching and learning.

Most developed countries now have an ECE curriculum, especially for children in the year before primary schooling, acknowledging that some structuring and orientation of children's experiences towards educational aims is beneficial (EIU, 2012; OECD, 2013; Pascal, \& Bertram, 2012). Curricula are influenced by many factors, including society's values, standards, research findings, community expectations, culture, and language. Although these factors differ by country, state, region, and even program, it is widely accepted that high quality ECE curricula provide appropriate developmental support and cognitive challenges that lead to positive child outcomes (OECD, 2006). A cross-national study (Pascal et al., 2012) reveals that many countries have or are developing national preschool curriculum guidelines, acknowledging their role in ensuring improved outcomes for children as they enter compulsory schooling.

There is continuing debate about the best curriculum approach for young children prior to compulsory schooling (Corak et al., 2012; OECD, 2012a). In many countries there is an emphasis on literacy and numeracy in official curricula. Where there is a social pedagogy tradition, emergent literacy and numeracy are not excluded, but a more open and holistic curriculum is promoted until children enter school and sometimes well into the early classes of primary school. In countries where early education has been strongly associated with primary school, there can also be a focus on school readiness and a more academic approach to curriculum and pedagogy. 
While literacy and numeracy appear to be academic subjects, it is possible to use childcentered pedagogic approaches, such as play, to develop these abilities in young children. Literacy is important for language development and providing the foundations for reading. It has been linked with improved school performance and achievement, and to productivity in later life (Mullis et al., 2012). Research from the United States, reported by Barnett et al. (2007) suggests that the key skills to be developed before primary school are: vocabulary use, listening skills, knowledge of the alphabet, and writing skills (Strickland, \& Riley-Ayers, 2006). Research into numeracy has suggested that the early childhood curriculum should focus on concepts that form the basis of mathematical competence, such as number, shape, and pattern (Ginsburg, \& Amit, 2008). Large-scale nationally representative longitudinal studies within the United States, such as the Early Childhood Longitudinal Study, Birth Cohort and the Early Childhood Longitudinal Study, Kindergarten Class of 2010-2011, recognize the importance of collecting information on children's reading, mathematics, executive functioning, approaches to learning, and social-emotional well-being.

Research has indicated that there are some areas of learning that are particularly vital to focus on in the foundation years of life (Corak et al., 2012; Nagaoka, Farrington, Ehrlich, \& Heath, 2015; Pascal, \& Bertram, 2008). Heckman (2012) emphasized that "life skills", such as conscientiousness, perseverance, motivation, sociability, attention, self-regulation and anger management, self-esteem, and the ability to defer gratification, should be the focus of an early years' curriculum. Recent research from neuroscience (Diamond, 2010) affirmed this approach to the early years' curriculum and identified a range of "executive functions" that are needed for a child to make educational progress. Three of these core functions appear to be particularly associated with longterm attainment and are vital for children to develop if the gap in achievement is to be narrowed: (1) cognitive flexibility, described as the ability to switch perspectives; (2) inhibitory control, namely the ability to stay focused despite distraction, have selective focused attention, and stay on task; and (3) working memory, described as the ability to hold information in mind and mentally work with it, make sense of what unfolds over time, relate events, ideas, and learning from before to now, reason, understand cause and effect, and remember multiple instructions in sequence and follow them step-bystep in correct order. There is evidence indicating that these aspects of development may be more important for academic success than intelligence quotient (IQ), entrylevel reading, or mathematics (Blair, \& Diamond 2008; Blair, \& Razza, 2007). Therefore, to support a child to be "school ready" and able to operate as an effective learner, the early years' curriculum needs to focus on both cognitive and non-cognitive aspects of early learning and, importantly, give children a sense of their own capacity to be successful learners.

ECE providers have a varied degree of choice over the curriculum they use. In some countries, the curriculum is devised by an external authority, such as central or local government. The OECD (2012b) reported that an early years' curriculum or standards for learning exists in almost all OECD countries covering the ages of three to the start of primary school. While some curricula specify what is expected of staff (notably in Nordic countries), others are based on the outcomes that children are expected to achieve (commonly found in Anglo-Saxon countries). The existence of a common curriculum allows an authority to set priorities, direct staff behavior and create continuity across the education system. However, a curriculum determined by an outside body may restrict a 
settings freedom to teach and care in the ways that it sees as most appropriate (OECD, 2006). There is much debate over the best curriculum and pedagogical approach for children in ECE and, while the aims may be similar, research has shown that early childhood curricula vary considerably in their scope, objectives, evaluation, methods, and perspectives on learning and quality (Pepper, \& May, 2009).

This wider policy debate about the need for an early childhood curriculum and its focus and nature, stimulated the ECES to investigate whether the study countries had national curriculum guidance for ECE, and if so, the scope of the guidance, the areas of learning it covered, and the pedagogical approaches it promoted (Table 23).

Table 23: Existence and content of curriculum guidance for children aged 0-3 years (ECED) and children aged 3 to the start of primary school (PPE)

\begin{tabular}{|c|c|c|c|c|c|c|c|}
\hline \multirow[b]{2}{*}{ Country } & \multirow[b]{2}{*}{ Level } & \multicolumn{6}{|c|}{ Aspects of national or typical subnational curriculum guidance } \\
\hline & & 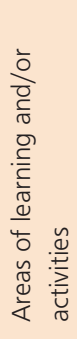 & 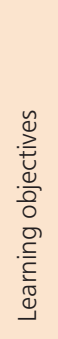 & 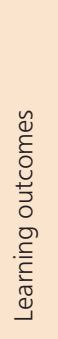 & 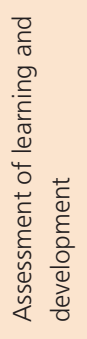 & 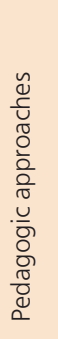 & 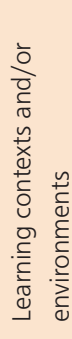 \\
\hline \multirow[t]{2}{*}{ Chile } & ECED & $\bullet$ & $\bullet$ & • & • & ○ & - \\
\hline & PPE & - & • & $\bullet$ & • & O & - \\
\hline \multirow[t]{2}{*}{ Czech Republic } & ECED & $\mathrm{n} / \mathrm{a}$ & $\mathrm{n} / \mathrm{a}$ & $\mathrm{n} / \mathrm{a}$ & $\mathrm{n} / \mathrm{a}$ & $\mathrm{n} / \mathrm{a}$ & $\mathrm{n} / \mathrm{a}$ \\
\hline & PPE & - & - & - & - & • & - \\
\hline \multirow[t]{2}{*}{ Denmark } & ECED & - & $\bullet$ & $\bullet$ & O & O & ○ \\
\hline & PPE & - & $\bullet$ & $\bullet$ & ○ & ○ & O \\
\hline \multirow[t]{2}{*}{ Estonia } & ECED & • & $\bullet$ & $\bullet$ & $\bullet$ & $\bullet$ & • \\
\hline & PPE & - & $\bullet$ & $\bullet$ & - & - & - \\
\hline \multirow[t]{2}{*}{ Italy } & ECED & $\mathrm{n} / \mathrm{a}$ & $\mathrm{n} / \mathrm{a}$ & $\mathrm{n} / \mathrm{a}$ & $\mathrm{n} / \mathrm{a}$ & $\mathrm{n} / \mathrm{a}$ & $\mathrm{n} / \mathrm{a}$ \\
\hline & PPE & $\bullet$ & $\bullet$ & $\bullet$ & O & - & $\bullet$ \\
\hline \multirow[t]{2}{*}{ Poland } & ECED & $\mathrm{n} / \mathrm{a}$ & $\mathrm{n} / \mathrm{a}$ & $\mathrm{n} / \mathrm{a}$ & $\mathrm{n} / \mathrm{a}$ & $\mathrm{n} / \mathrm{a}$ & $\mathrm{n} / \mathrm{a}$ \\
\hline & PPE & - & - & - & - & • & O \\
\hline \multirow{2}{*}{$\begin{array}{l}\text { Russian } \\
\text { Federation }\end{array}$} & ECED & - & $\bullet$ & O & - & $\bullet$ & - \\
\hline & PPE & - & $\bullet$ & O & • & - & - \\
\hline \multirow[t]{2}{*}{ United States } & ECED & - & $\bullet$ & $\bullet$ & • & $\bullet$ & • \\
\hline & PPE & - & $\bullet$ & $\bullet$ & - & - & - \\
\hline
\end{tabular}

Key:

- Yes, national guidance includes this aspect.

- No, national guidance does not include this aspect.

n/a Not applicable, as no national curriculum guidance exists. 
All eight of the study countries have national curriculum guidance (sometimes statutory) for children from three years to the start of primary school (PPE) and five countries have curriculum guidance (sometimes statutory) for children from birth to three years (the Czech Republic, Italy and Poland do not have curriculum guidance for this age phase) (Table 23). This suggests that the majority of countries see the key role played by ECE in supporting children's learning and development. In Italy, the education system reform of July 2015 introduced future regulations on structural, organizational and quality aspects of services for children from birth to six years to be integrated under the responsibility of the Ministry of Education. Given Italy is in the transition period toward new legislation, it is difficult to report if and how a curriculum for children from birth to three years will also be introduced. For ECED in the Czech Republic, there is only a general statement that education should take place for crèche provision and, for other forms of ECED provision there is only a requirement that education should be appropriate to the developmental level of the child. It should be noted that the United States NRC stated that there are no national curricula, but rather national guidance on elements that should be covered in curricula in ECE settings. Individual states have defined their own early learning standards covering birth to five years.

All countries indicated that the national guidance includes a specification of the areas of learning or the kinds of learning activities to be offered, and the learning objectives for children at different ages and in different areas of learning. Such advice also (excluding Italy) includes guidance on the assessment of learning and development, and all bar the Russian Federation also specify the desired learning outcomes for children at each stage. Six countries provide guidance on learning environments and recommended pedagogic approaches (excluding Denmark and Chile). The data suggest that the curriculum guidance for both age phases is broad in scope and usually provides specific guidance on learning content, pedagogic approaches, learning goals and assessment (Table 24).

Curriculum guidance in all the study countries promotes a broad and balanced range of learning areas throughout the age phases, with no narrowing of curriculum focus as the child heads towards entry to primary schooling (Table 24). Countries reported that both cognitive and non-cognitive areas were included in curriculum guidance. It is notable that the majority of countries do not include a foreign/second language or religious and spiritual education in their guidance. The United States stated that learning a foreign language tends to be included in curriculum guidance at the kindergarten level. In Italy, Catholic religious guidance is only included for those parents who request it at individual school level; this area is regulated outside the national curriculum by a specific agreement (Italian Presidential Decree of the 11 February 2010) and guidelines set by the Roman Catholic Church and the state. Technology is another area that is less well covered for the under-threes, although some countries (the Russian Federation and the United States) indicated that this area is increasingly being addressed.

A report on ECE in Europe (Eurydice, 2009) identified a child-centered approach as the model found most commonly in early childhood settings in the European Union. Child-centered approaches have developed from the theories of influential pedagogues (such as Fröbel, Pestalozzi, Dewey, and Montessori). They are intended to develop an individual through self-determined activity, interacting with peers, and learning through cooperative behavior and play. This contrasts with a teacher-directed approach, in which the adult's role is to transmit knowledge and skills to the children. In their report arising from an OECD conference on early childhood policy, Pramling Samuelsson et al. (2006) discussed the characteristics of five selected pedagogical approaches adopted 
Table 24: Areas of learning included in curriculum guidance for children aged 0-3 years (ECED) and children aged 3 to the start of primary school (PPE)

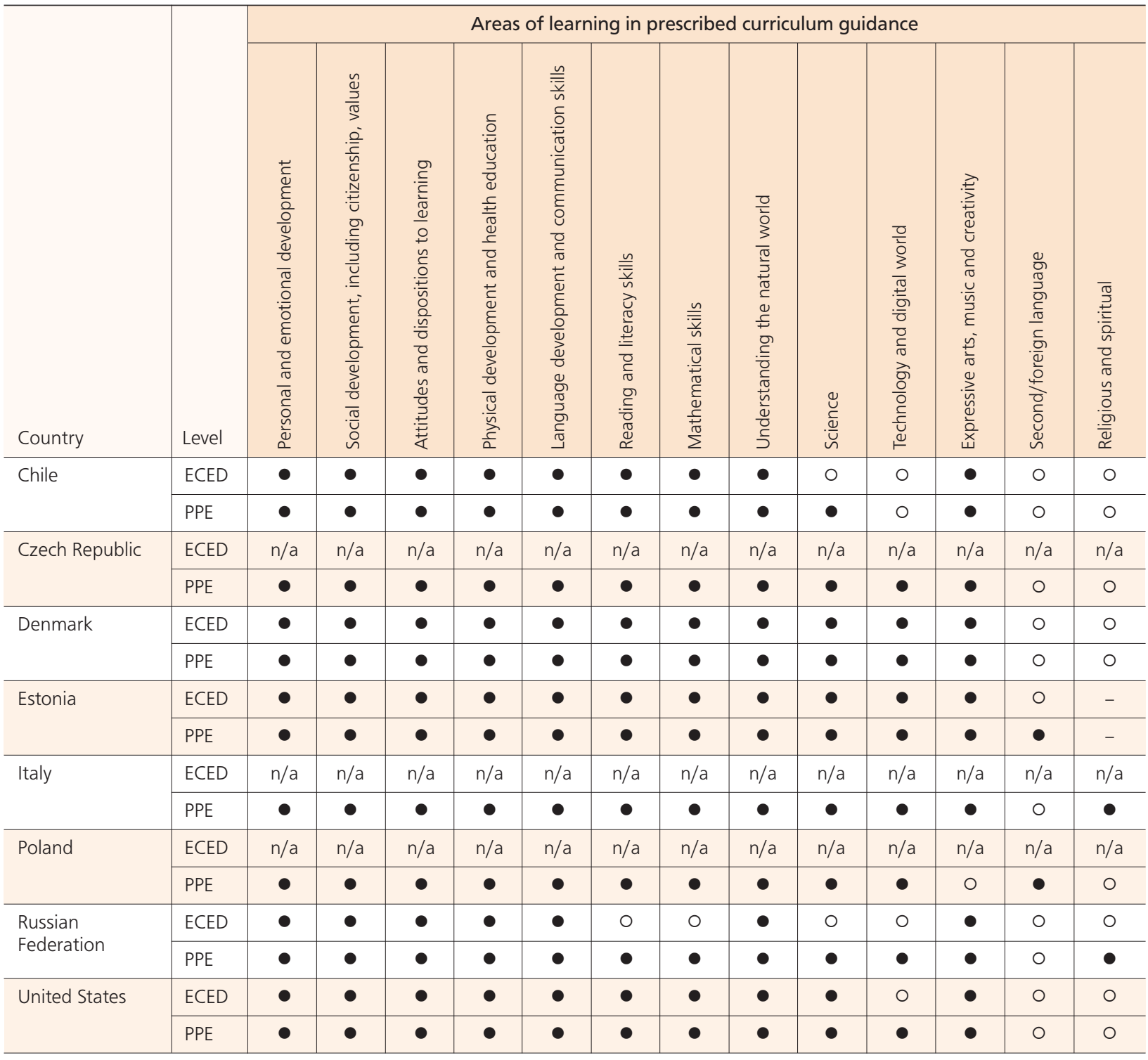

Key:

- Yes, national guidance includes this area of learning.

- No, national guidance does not include this area of learning.

n/a Not applicable, as no national curriculum guidance exists.

- No data provided.

by preschool settings from across the world: namely Reggio Emilia (Italy), Te Whäriki (New Zealand), Experiential Education (Belgium), HighScope (USA), and the Swedish National Curriculum for Pre-school. These were similar in a number of respects, including: recognition of each child's rights, the central role of interactive play, the importance of parental involvement, and the encouragement of staff development. The main differences were the importance given to the child's view, the influence of the learning environment, and the emphasis on assessment and evaluation. This diversity in pedagogic approach has been shown to be evident both between and within countries in a number of recent policy studies (Corak et al., 2012; EIU, 2012; OECD, 2012a).

The ECES examined the existence and range of nationally promoted pedagogic approaches in the study countries (Table 25). 
Table 25: Pedagogic approaches promoted in national guidance for children aged 0-3 years (ECED) and children aged 3 to the start of primary school (PPE)

\begin{tabular}{|c|c|c|c|c|c|c|}
\hline \multirow[b]{2}{*}{ Country } & \multirow[b]{2}{*}{ Level } & \multicolumn{5}{|c|}{ Pedagogic approaches promoted in national guidance } \\
\hline & & $\begin{array}{l}\text { Academic, } \\
\text { formal } \\
\text { instruction } \\
\text { approach }\end{array}$ & $\begin{array}{l}\text { Creative, } \\
\text { progressive } \\
\text { learning } \\
\text { approach }\end{array}$ & $\begin{array}{l}\text { Experiential } \\
\text { learning } \\
\text { approach }\end{array}$ & $\begin{array}{l}\text { Play } \\
\text { curriculum } \\
\text { approach }\end{array}$ & $\begin{array}{c}\text { Specific } \\
\text { philosophy,e.g. } \\
\text { Montessori/ } \\
\text { Steiner }\end{array}$ \\
\hline \multirow[t]{2}{*}{ Chile } & ECED & $\mathrm{n} / \mathrm{a}$ & $\mathrm{n} / \mathrm{a}$ & $\mathrm{n} / \mathrm{a}$ & $\mathrm{n} / \mathrm{a}$ & $n / a$ \\
\hline & PPE & $\mathrm{n} / \mathrm{a}$ & $\mathrm{n} / \mathrm{a}$ & $\mathrm{n} / \mathrm{a}$ & $\mathrm{n} / \mathrm{a}$ & $\mathrm{n} / \mathrm{a}$ \\
\hline \multirow[t]{2}{*}{ Czech Republic } & ECED & $n / a$ & $n / a$ & $n / a$ & $\mathrm{n} / \mathrm{a}$ & $\mathrm{n} / \mathrm{a}$ \\
\hline & PPE & $\mathrm{n} / \mathrm{a}$ & $\mathrm{n} / \mathrm{a}$ & $\mathrm{n} / \mathrm{a}$ & $\mathrm{n} / \mathrm{a}$ & $\mathrm{n} / \mathrm{a}$ \\
\hline \multirow[t]{2}{*}{ Denmark $^{a}$} & ECED & O & O & O & O & ○ \\
\hline & PPE & O & O & O & O & O \\
\hline \multirow[t]{2}{*}{ Estonia } & ECED & 0 & $\bullet$ & $\bullet$ & $\bullet$ & $\bullet$ \\
\hline & PPE & 0 & $\bullet$ & $\bullet$ & $\bullet$ & $\bullet$ \\
\hline \multirow[t]{2}{*}{ Italy b } & ECED & $\mathrm{n} / \mathrm{a}$ & $\mathrm{n} / \mathrm{a}$ & $\mathrm{n} / \mathrm{a}$ & $\mathrm{n} / \mathrm{a}$ & $\mathrm{n} / \mathrm{a}$ \\
\hline & PPE & 0 & O & 0 & 0 & 0 \\
\hline \multirow[t]{2}{*}{ Poland } & ECED & $\mathrm{n} / \mathrm{a}$ & $\mathrm{n} / \mathrm{a}$ & $\mathrm{n} / \mathrm{a}$ & $\mathrm{n} / \mathrm{a}$ & $\mathrm{n} / \mathrm{a}$ \\
\hline & PPE & $\bullet$ & O & - & O & O \\
\hline \multirow{2}{*}{$\begin{array}{l}\text { Russian } \\
\text { Federation }\end{array}$} & ECED & O & - & $\bullet$ & • & O \\
\hline & PPE & 0 & - & - & - & 0 \\
\hline \multirow[t]{2}{*}{ United States } & ECED & $\bullet$ & $\bullet$ & - & $\bullet$ & 0 \\
\hline & PPE & $\bullet$ & $\bullet$ & $\bullet$ & • & 0 \\
\hline \multicolumn{7}{|c|}{$\begin{array}{l}\text { - Yes, national guidance includes this approach. } \\
\text { n No, national guidance does not include this approa } \\
\text { n/a Not applicable, as no national guidance provided. }\end{array}$} \\
\hline \multicolumn{7}{|c|}{$\begin{array}{l}\text { In Denmark, although there is national guidance on pedagogic approaches, centers are free to choose their } \\
\text { preferred approach. } \\
\text { b In Italy, a person-centered humanistic approach, inclusive and intercultural, was explicitly included in the initial } \\
\text { part of the } 2012 \text { curriculum guidelines. This is based on the values included in the Italian Constitution and } \\
\text { refers to the entire curricular } 3-14 \text { age range, from preschool to lower secondary. No specific approach is } \\
\text { emphasized nor recommended, as schools are autonomous and teachers' autonomy is guaranteed by the } \\
\text { Italian Constitution. }\end{array}$} \\
\hline
\end{tabular}

Four of the study countries have national or subnational guidance on pedagogic approaches for children under the age of three (Denmark, Estonia, the Russian Federation and the United States) and four do not (Chile, the Czech Republic, Italy currently, and Poland) (Table 25). The evidence indicates that, in the majority of countries, a broad range of pedagogic approaches are promoted. For example, in Estonia, the Russian Federation and the United States, four or more approaches are promoted, including a creative, progressive learning approach; an experiential learning approach; a play curriculum approach; a specific philosophy; and, in the United States, an academic, formal instruction approach. Six countries have national or subnational guidance on pedagogic approaches for children from age three to primary school age (Denmark, Estonia, Italy, Poland, the Russian Federation and the United States). Again, a similar range of pedagogies are promoted, but with two countries including an academic, formal instruction approach (Poland and the United States). 
Note that no single pedagogic approach is more frequently reported over others for either younger or older children, but rather a range of pedagogies are encouraged, including more progressive, play-based, and child-centered approaches and more academic, formal, instructional approaches. This seems to suggest some choice and freedom for settings to develop their preferred approach. Denmark emphasized that centers are encouraged to choose their own pedagogic approach, and there seems to be some measure of flexibility in all the study countries.

\section{Summary Finding 28}

The study shows that national curriculum guidance, which usually includes guidance on learning content and learning standards, has been developed for early childhood services in the majority of the study countries; this is broad in scope and provides specific guidance on learning content, pedagogic approaches, learning goals, and assessment. The guidance promotes a broad and balanced range of learning areas to be covered throughout the age phases, with no narrowing of curriculum focus as the child heads towards entry to primary schooling. Countries report that both cognitive and non-cognitive areas are included in curriculum guidance at both age phases. All countries reported that a range of pedagogies is encouraged, including more play-based approaches and more academic, formal, instructional approaches. This suggests settings have some choice and freedom to develop their preferred approach.

\section{Parental Participation In Learning}

There is well-established evidence indicating that those early childhood programs that combine high-quality cognitively-oriented learning experiences for children with parenting support and strategies to encourage parental participation are more effective in enhancing long-term outcomes for children, particularly those from less advantaged home backgrounds (Corak et al., 2012; Sylva et al., 2008; Waldfogel, 2012; Waldfogel, \& Washbrook, 2008).

The encouragement of parental participation in early childhood programs is a key area where further action is required. Most evidence reveals that early education programs that encourage high levels of parent engagement with their children's learning are more successful in closing the attainment gap for socially disadvantaged children. The most effective settings shared child-related information between children and staff, and more particularly, children did better where the center shared its educational aims with parents. This enabled parents to support children at home with activities or materials that complemented those experiences in the setting. The "winning formula" consists of combining education of the young child in a formal setting with support for parents (Corak et al., 2012; Pascal, \& Bertram, 2012; Sylva et al., 2008).

The ECES investigated whether there was guidance in the study countries to support parental participation in early childhood settings and what level of participation they had achieved (Table 26). The level and nature of participation was assessed using a three-level assessment of participation. At the first level, participation is characterized as being about information transmission, mainly from setting to parent. This may be realized through leaflets, newsletters, parent meetings, parent visits to setting, and 
reports. At the second level, there is a more reciprocal partnership, characterized by consultation and dialogue. This may be achieved through child assessment meetings, surveys, feedback activities, parent group meetings. At the third level, participation is characterized by much more parent involvement in the learning processes within the setting. This is realized through parent participation on advisory boards, parents helping out in the classroom, parent meetings to plan a child's learning program, and parent participation in evaluative processes.

Table 26: Existence of guidance on parental partnership and level of parent participation in settings for children aged 0-3 years (ECED) and children aged 3 to the start of primary school (PPE)

\begin{tabular}{|c|c|c|c|c|}
\hline \multirow[b]{2}{*}{ Country } & \multirow[b]{2}{*}{ Level } & \multicolumn{3}{|c|}{ Nature of guidance to support parental participation } \\
\hline & & $\begin{array}{c}\text { Level 1: } \\
\text { Information } \\
\text { transmission }\end{array}$ & $\begin{array}{c}\text { Level 2: } \\
\text { Consultation } \\
\text { and dialogue }\end{array}$ & $\begin{array}{l}\text { Level 3: } \\
\text { Active involvement } \\
\text { and participation }\end{array}$ \\
\hline \multirow[t]{2}{*}{ Chile } & ECED & $\bullet$ & $\bullet$ & O \\
\hline & PPE & $\bullet$ & - & O \\
\hline \multirow[t]{2}{*}{ Czech Republic } & ECED & $\mathrm{n} / \mathrm{a}$ & $\mathrm{n} / \mathrm{a}$ & $\mathrm{n} / \mathrm{a}$ \\
\hline & PPE & $\bullet$ & - & $\bullet$ \\
\hline \multirow[t]{2}{*}{ Denmark } & ECED & • & - & - \\
\hline & PPE & $\bullet$ & - & $\bullet$ \\
\hline \multirow[t]{2}{*}{ Estonia } & ECED & - & - & - \\
\hline & PPE & $\bullet$ & - & $\bullet$ \\
\hline \multirow[t]{2}{*}{ Italy } & ECED & $\mathrm{n} / \mathrm{a}$ & $\mathrm{n} / \mathrm{a}$ & $\mathrm{n} / \mathrm{a}$ \\
\hline & PPE & 0 & - & - \\
\hline \multirow[t]{2}{*}{ Poland } & ECED & $\mathrm{n} / \mathrm{a}$ & $\mathrm{n} / \mathrm{a}$ & $n / a$ \\
\hline & PPE & - & 0 & - \\
\hline \multirow{2}{*}{$\begin{array}{l}\text { Russian } \\
\text { Federation }\end{array}$} & ECED & $\bullet$ & - & - \\
\hline & PPE & - & - & - \\
\hline \multirow[t]{2}{*}{ United States } & ECED & $\bullet$ & - & - \\
\hline & PPE & $\bullet$ & - & $\bullet$ \\
\hline
\end{tabular}

Key:

- Yes, national guidance includes this level.

- No, national guidance does not include this level.

n/a Not applicable, as no national guidance exists.

All of the study countries have national guidance on parental participation at PPE level and the majority of countries also include ECED level settings in the guidance (Table 26). Three countries did not have this guidance for parents of under-threes (the Czech Republic, Italy and Poland). All countries, except Chile, encouraged parental participation at all three levels, suggesting that priority is given to supporting parental participation at policy level.

In Chile, it is reported that parents are seen as crucial in the educational process. It was reported that the Danish pedagogue has a long tradition of a close and respectful dialogue and involvement with parents, and that all settings have policies for parental participation through meetings, formal and informal gatherings, home visits, and using printed and electronic communication. Danish law also emphasizes that staff and 
parents should work together in giving the children care, supporting their development, and developing their self-esteem. In the Russian Federation, Federal State Law 273 "On Education" states that a parents' council must be created in all settings, parents must be aware of the license for educational activity, and parents must receive copies of the setting's certificates of accreditation and program details. A setting must also support parents in raising their children, child protection and promotion of child health, and directly involve parents in the educational activity.

\section{Summary Finding 29}

It is evident in all the study countries that engaging families and parents in partnership with ECE programs, and encouraging their active participation in the life of the setting and in the development and education of their child, is a central element in policy strategies.

\section{Accreditation, Inspection, Reporting and Accountability}

The development of enhanced statutory standards, a comprehensive regulatory framework, and more efficient systems to manage data, measure quality and evidence the impact of practice has been shown to be associated with better quality, more effective targeting, the efficient deployment of resources at all levels, and improved outcomes for the less advantaged (Corak et al., 2012; OECD, 2006; Pascal, \& Bertram, 2012). The OECD (2012b) has described the existence of data and monitoring systems as essential in order for ECE settings to be accountable to parents and other stakeholders. They can contribute to helping parents make decisions about their choice of setting, can help inform planning and resource allocation, strengthen policy making, improve pedagogical practices, and potentially improve child outcomes if developed and aligned with quality goals. A variety of features can be monitored, including child development, staff performance, service quality, regulation compliance, and working conditions. Many countries ensure that early childhood settings adopt policies and procedures intended to assure quality and are subject to inspection by external assessors. These accountability measures are designed to ensure minimum standards are achieved and demonstrate the quality of the setting (Pascal, \& Bertram, 2012). These reports on quality are often used to support service accountability and performance management, and to inform parental choice in ECE.

Quality assurance is the regular and continuous process by which those who work in, or administer, ECE ensure that children receive a quality experience. Two key mechanisms for quality assurance are accreditation and inspection, which may be undertaken internally or externally by independent assessors or inspectors.

Accreditation of settings is the process of gaining official approval from an independent external body, usually involving a site visit and inspection to assess whether the setting owners have met minimum requirements for operation. Accreditation can be given before a setting opens or shortly after opening, and sometimes has to be regularly renewed.

Inspection is the act of looking at something closely in order to learn more about it, to find problems, to scrutinize or assess it. Sometimes inspection processes are standardized nationally or subnationally to enable comparisons between one setting and another. 
Most countries have an inspection service that includes an official visit to a setting. As assuring and monitoring the quality of ECE provision becomes more important, the evidence shows that countries are developing more robust and universally applied accreditation and inspection processes (EIU, 2012; OECD, 2006, 2012b).

The importance of this aspect of quality assurance is recognized in the ECES and evidence was gathered in the study countries on accreditation and inspection processes, and also on reporting and accountability procedures. The evidence collected from the study countries identifies where responsibility for accreditation and inspection lies and what aspects of ECE provision are covered by accreditation and inspection processes (Table 27). Finally, it sets out how accreditation and inspection evidence is reported to parents and others, and how such evidence is used. For Italy the situation in 2014 has been reported, but the July 2015 education system reform and announced regulations on the reunification of ISCED 0 system could lead to alterations.

Table 27: Existence of a responsible body at national or subnational level for the accreditation of settings for children aged 0-3 years (ECED) and children aged 3 to the start of primary school (PPE)

\begin{tabular}{|c|c|c|c|}
\hline \multirow[b]{2}{*}{ Country } & \multirow[b]{2}{*}{ Level } & \multicolumn{2}{|c|}{ Existence of a body (or bodies) responsible for accreditation } \\
\hline & & A national body & A typical subnational body \\
\hline \multirow[t]{2}{*}{ Chile } & ECED & $\bullet$ & O \\
\hline & PPE & $\bullet$ & O \\
\hline \multirow[t]{2}{*}{ Czech Republic } & ECED & $\bullet$ & o \\
\hline & PPE & $\bullet$ & O \\
\hline \multirow[t]{2}{*}{ Denmark $^{a}$} & ECED & O & O \\
\hline & PPE & O & O \\
\hline \multirow[t]{2}{*}{ Estonia } & ECED & $\bullet$ & O \\
\hline & PPE & $\bullet$ & O \\
\hline \multirow[t]{2}{*}{ Italy } & ECED & O & $\bullet$ \\
\hline & PPE & $\bullet$ & $\bullet$ \\
\hline \multirow[t]{2}{*}{ Poland } & ECED & 0 & $\bullet$ \\
\hline & PPE & O & $\bullet$ \\
\hline \multirow{2}{*}{$\begin{array}{l}\text { Russian } \\
\text { Federation }\end{array}$} & ECED & O & O \\
\hline & PPE & O & 0 \\
\hline \multirow[t]{2}{*}{ United States ${ }^{b}$} & ECED & $\bullet$ & $\bullet$ \\
\hline & PPE & $\bullet$ & $\bullet$ \\
\hline $\begin{array}{l}\text { Key: } \\
\text { Yes, accredit } \\
\text { O No, accredita }\end{array}$ & \multicolumn{3}{|c|}{$\begin{array}{l}\text { Yes, accreditation body exists } \\
\text { No, accreditation body does not exist. }\end{array}$} \\
\hline \multicolumn{4}{|c|}{$\begin{array}{l}\text { a In Denmark it is reported that there is no accreditation because the pedagogic standard is assumed to be high } \\
\text { as the pedagogues are trained and all facilities are run and controlled by local authorities. }\end{array}$} \\
\hline
\end{tabular}


All the study countries, except for Denmark and the Russian Federation, have bodies with responsibility for setting accreditation (Table 27). For three countries this is located at a national level (Chile, the Czech Republic and Estonia); for one country it is located at a subnational level (Poland); and for two countries responsibility is distributed across national and subnational levels (Italy PPE is controlled at the national level, and ECED only at subnational level, while the United States has responsible bodies at both levels).

In Chile, there are different bodies involved in the certification and inspection of ECED and PPE settings, and they may need authorization from a number of these. For example, a setting needs municipality authorization, official recognition from the Ministry of Education, and certification from the National Board of Kindergartens (JUNJI). For children from age four to six years, the Ministry of Education is the accrediting body. Denmark stated that there is no accreditation system, but that the local communities are responsible for ensuring all centers meet national requirements. In Italy, the Ministry of Education has responsibility for accrediting non-state schools. At the municipal level, a combination of municipal and state accreditation for private and for public non-state schools might be required. Accreditation is often linked to some kind of public subsidy. In the Russian Federation, there is only licensing for ECE settings, as accreditation was cancelled some years ago. Quality is controlled by the Federal Standard of Preschool Education, which guarantees the quality of the setting if it meets the standard; powers of regulating quality have been transferred to regional authorities. The United States reported that they have a voluntary system of accreditation, and accreditation guidelines often exceed those of licensing guidelines. Examples of the range of accrediting bodies include the National Association for the Education of Young Children, Head Start Renewal system, Montessori, Reggio Emilia Alliance, and the IB Primary Years Program.

The evidence suggests that although accreditation of settings is seen as important to sustaining the quality of ECE, countries approach it very differently, with some having no system in place, some having one clear body with responsibility, while others spread responsibility between different bodies at different levels in the system. For some countries the accreditation process is mandatory and for others it is voluntary.

All study countries have bodies with responsibility for setting inspection (Table 28). For children under the age of three, seven countries have bodies with responsibility for inspection, with only the Czech Republic not having a responsible body during this age phase. In Chile, the body is at national level, and, in Denmark, Italy, Poland and the Russian Federation, these bodies are at subnational level. In Estonia and the United States, there are bodies at both national and subnational level.

For children from age three to primary school age, all of the study countries have bodies with responsibility for setting inspection. For Chile and the Czech Republic this is at a national level; for Denmark, Poland and the Russian Federation this is located at a subnational level; and, in Estonia, Italy and the United States, this is distributed across national and subnational levels, with Italian ECED only at subnational level.

In Denmark, the local communities have responsibility for inspecting all centers on a regular basis. In the Czech Republic, the Czech School Inspectorate has responsibility for inspecting ECE settings. In Italy, inspection for ECED settings is seen as part of the accreditation and authorization process, and is carried out mainly at local municipal or district level. At PPE level, national inspectors and inspectors of the regional scholastic 
Table 28: Existence of a responsible body at national or subnational level for the inspection of settings for children aged 0-3 years (ECED) and children aged 3 to the start of primary school (PPE)

\begin{tabular}{|c|c|c|c|}
\hline \multirow[b]{2}{*}{ Country } & \multirow[b]{2}{*}{ Level } & \multicolumn{2}{|c|}{ Existence of a body (or bodies) responsible for inspection } \\
\hline & & A national body & A typical subnational body \\
\hline \multirow[t]{2}{*}{ Chile } & ECED & $\bullet$ & O \\
\hline & PPE & $\bullet$ & O \\
\hline \multirow[t]{2}{*}{ Czech Republic } & ECED & O & O \\
\hline & PPE & $\bullet$ & O \\
\hline \multirow[t]{2}{*}{ Denmark } & ECED & O & $\bullet$ \\
\hline & PPE & O & $\bullet$ \\
\hline \multirow[t]{2}{*}{ Estonia } & ECED & $\bullet$ & $\bullet$ \\
\hline & PPE & $\bullet$ & $\bullet$ \\
\hline \multirow[t]{2}{*}{ Italy } & ECED & O & $\bullet$ \\
\hline & PPE & $\bullet$ & $\bullet$ \\
\hline \multirow[t]{2}{*}{ Poland } & ECED & O & $\bullet$ \\
\hline & PPE & O & $\bullet$ \\
\hline \multirow{2}{*}{$\begin{array}{l}\text { Russian } \\
\text { Federation }\end{array}$} & ECED & O & $\bullet$ \\
\hline & PPE & O & $\bullet$ \\
\hline \multirow[t]{2}{*}{ United States } & ECED & $\bullet$ & $\bullet$ \\
\hline & PPE & $\bullet$ & $\bullet$ \\
\hline
\end{tabular}

\section{Key:}

- Yes, inspection body exists

O No, inspection body does not exist.

offices generally inspect state and non-state schools. It was reported that in 2014 this technical position was not well defined in Italy and was the subject of debate within the newly launched National System for the Evaluation of Education. In Poland, settings for under-threes are supervised by the commune mayors and for older children, facilities are supervised by the heads of the regional education authorities. In the Russian Federation, inspection is carried out by other bodies that operate at federal and regional level, including federal and regional services for supervision in education and the Russian Federal Service for Surveillance on Consumer Rights Protection and Human Well-being. In the United States, each state has its own licensing inspections; the federal government monitors and inspects Head Start programs.

The ECES also explored what aspects of provision were covered by accreditation and inspection procedures, which give an indication of what are seen as key elements of quality provision (Tables 29 and 30). 
Table 29: Aspects of quality assurance processes covered by accreditation for children aged $0-3$ years (ECED) and children aged 3 to the start of primary school (PPE)

\begin{tabular}{|c|c|c|c|c|c|c|c|c|c|c|}
\hline \multirow[b]{2}{*}{ Country } & \multirow[b]{2}{*}{ Level } & \multicolumn{9}{|c|}{ Aspects of quality assurance covered by accreditation } \\
\hline & & 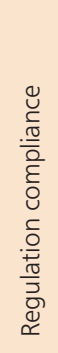 & 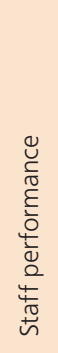 & 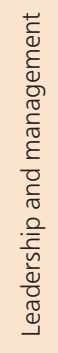 & 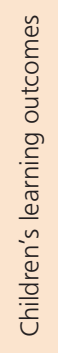 & 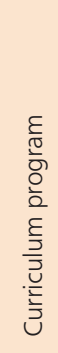 & 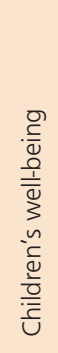 & 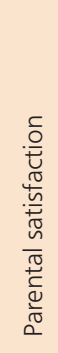 & 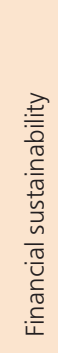 & $\begin{array}{l}\text { む) } \\
\frac{c}{0} \\
\text { ह } \\
\frac{1}{0} \\
\frac{0}{2} \\
\frac{0}{\pi}\end{array}$ \\
\hline \multirow[t]{2}{*}{ Chile } & ECED & $\bullet$ & O & - & O & $\bullet$ & O & O & $\bullet$ & O \\
\hline & PPE & $\bullet$ & $\bullet$ & • & O & $\bullet$ & ○ & O & $\bullet$ & O \\
\hline \multirow[t]{2}{*}{ Czech Republic } & ECED & $\mathrm{n} / \mathrm{a}$ & $\mathrm{n} / \mathrm{a}$ & $\mathrm{n} / \mathrm{a}$ & $\mathrm{n} / \mathrm{a}$ & $\mathrm{n} / \mathrm{a}$ & $\mathrm{n} / \mathrm{a}$ & $\mathrm{n} / \mathrm{a}$ & $\mathrm{n} / \mathrm{a}$ & $\mathrm{n} / \mathrm{a}$ \\
\hline & PPE & 0 & O & O & O & O & 0 & O & 0 & O \\
\hline \multirow[t]{2}{*}{ Denmark $^{a}$} & ECED & O & O & O & 0 & 0 & 0 & 0 & 0 & O \\
\hline & PPE & O & O & O & O & O & O & O & O & O \\
\hline \multirow[t]{2}{*}{ Estonia } & ECED & $\bullet$ & O & - & O & $\bullet$ & 0 & 0 & $\bullet$ & O \\
\hline & PPE & $\bullet$ & 0 & $\bullet$ & O & $\bullet$ & 0 & O & $\bullet$ & O \\
\hline \multirow[t]{2}{*}{ Italy } & ECED & $\bullet$ & O & O & O & O & O & O & O & O \\
\hline & PPE & $\bullet$ & O & O & O & - & O & O & 0 & O \\
\hline \multirow[t]{2}{*}{ Poland } & ECED & $\bullet$ & O & O & O & O & 0 & O & 0 & O \\
\hline & PPE & $\bullet$ & O & 0 & O & $\bullet$ & 0 & O & 0 & O \\
\hline \multirow{2}{*}{$\begin{array}{l}\text { Russian } \\
\text { Federation }\end{array}$} & ECED & 0 & O & O & O & O & 0 & O & O & O \\
\hline & PPE & O & O & O & O & O & O & 0 & O & O \\
\hline \multirow[t]{2}{*}{ United States } & ECED & - & $\bullet$ & $\bullet$ & O & $\bullet$ & $\bullet$ & $\bullet$ & $\bullet$ & O \\
\hline & PPE & - & - & $\bullet$ & 0 & • & $\bullet$ & $\bullet$ & • & 0 \\
\hline
\end{tabular}

Key:

- Yes, aspect covered.

- No, aspect not covered.

n/a Not applicable, as no accreditation exists.

Country Specific Note:

a In Denmark it is reported that there is no accreditation because the pedagogic standard is assumed to be high as the pedagogues are trained and all facilities are run and controlled by local authorities. There are no standards for accreditation, but the local communities have to meet the standards of the national laws.

The evidence shows that the most frequently reported aspect covered by the accreditation process is regulation compliance (Chile, Estonia, Italy, Poland and the United States), followed by the curriculum program (Chile, Estonia, Italy [PPE], Poland [PPE] and the United States), and financial sustainability (Chile, Estonia, the United States). Children's learning outcomes and value for money were the least covered aspects of quality in the study countries. 
Table 30: Aspects of quality assurance processes covered by inspection for children aged 0-3 years (ECED) and children aged 3 to the start of primary school (PPE)

\begin{tabular}{|c|c|c|c|c|c|c|c|c|c|c|}
\hline \multirow[b]{2}{*}{ Country } & \multirow[b]{2}{*}{ Level } & \multicolumn{9}{|c|}{ Aspects of quality assurance covered by inspection } \\
\hline & & 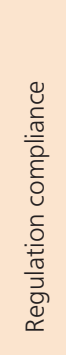 & 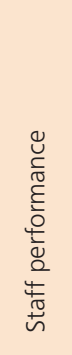 & 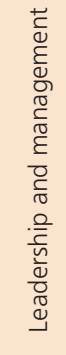 & 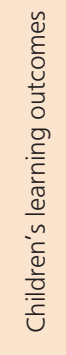 & 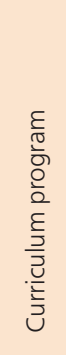 & 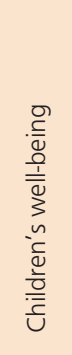 & 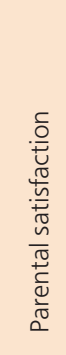 & 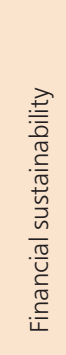 & 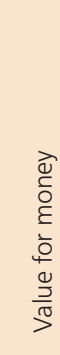 \\
\hline \multirow[t]{2}{*}{ Chile } & ECED & $\bullet$ & O & $\bullet$ & O & O & O & O & $\bullet$ & O \\
\hline & PPE & $\bullet$ & $\bullet$ & $\bullet$ & $\bullet$ & $\bullet$ & o & ० & $\bullet$ & O \\
\hline \multirow[t]{2}{*}{ Czech Republic } & ECED & $\mathrm{n} / \mathrm{a}$ & $\mathrm{n} / \mathrm{a}$ & $\mathrm{n} / \mathrm{a}$ & $\mathrm{n} / \mathrm{a}$ & $\mathrm{n} / \mathrm{a}$ & $\mathrm{n} / \mathrm{a}$ & $\mathrm{n} / \mathrm{a}$ & $\mathrm{n} / \mathrm{a}$ & $\mathrm{n} / \mathrm{a}$ \\
\hline & PPE & $\bullet$ & $\bullet$ & $\bullet$ & $\bullet$ & $\bullet$ & $\bullet$ & O & $\bullet$ & $\bullet$ \\
\hline \multirow[t]{2}{*}{ Denmark } & ECED & $\bullet$ & $\bullet$ & $\bullet$ & $\bullet$ & $\bullet$ & $\bullet$ & $\bullet$ & $\bullet$ & $\bullet$ \\
\hline & PPE & $\bullet$ & $\bullet$ & $\bullet$ & $\bullet$ & $\bullet$ & $\bullet$ & $\bullet$ & $\bullet$ & $\bullet$ \\
\hline \multirow[t]{2}{*}{ Estonia } & ECED & $\bullet$ & $\bullet$ & $\bullet$ & $\bullet$ & $\bullet$ & $\bullet$ & $\bullet$ & $\bullet$ & $\bullet$ \\
\hline & PPE & $\bullet$ & $\bullet$ & $\bullet$ & $\bullet$ & $\bullet$ & $\bullet$ & $\bullet$ & $\bullet$ & $\bullet$ \\
\hline \multirow[t]{2}{*}{ Italy } & ECED & $\bullet$ & O & O & O & O & O & O & O & O \\
\hline & PPE & $\bullet$ & O & O & O & $\bullet$ & O & O & O & 0 \\
\hline \multirow[t]{2}{*}{ Poland } & ECED & $\bullet$ & O & O & O & O & 0 & O & O & O \\
\hline & PPE & $\bullet$ & $\bullet$ & $\bullet$ & $\bullet$ & $\bullet$ & $\bullet$ & $\bullet$ & $\bullet$ & O \\
\hline \multirow{2}{*}{$\begin{array}{l}\text { Russian } \\
\text { Federation }\end{array}$} & ECED & $\bullet$ & O & O & O & O & O & O & $\bullet$ & $\bullet$ \\
\hline & PPE & $\bullet$ & O & O & O & O & O & 0 & $\bullet$ & $\bullet$ \\
\hline \multirow[t]{2}{*}{ United States } & ECED & $\bullet$ & $\bullet$ & $\bullet$ & $\bullet$ & $\bullet$ & $\bullet$ & $\bullet$ & $\bullet$ & O \\
\hline & PPE & $\bullet$ & $\bullet$ & $\bullet$ & $\bullet$ & $\bullet$ & $\bullet$ & $\bullet$ & $\bullet$ & 0 \\
\hline $\begin{array}{l}\text { Key: } \\
\text { - Yes, aspec } \\
0 \text { No, aspec }\end{array}$ & jered. & & & & & & & & & \\
\hline
\end{tabular}

The evidence shows a wider spread of coverage for inspection than accreditation but again the most frequently reported aspect is regulation compliance (Chile, the Czech Republic, Denmark, Estonia, Italy, Poland, the Russian Federation and the United States), followed by financial sustainability (Chile, the Czech Republic, Estonia, the Russian Federation and the United States).

\section{Summary Finding $\mathbf{3 0}$}

The data suggest that, in the study countries, inspection is more frequently reported than accreditation as a means to assure quality services at both ECED and PPE levels, although in the majority of countries the two processes complement one another, with inspection more commonly used to monitor setting quality and provide accreditation for authorization of setting quality. 
As governments and parents increase the amount of investment in ECE provision, there is a consequent demand that services be accountable and transparent about their performance. There is a shift towards more open, understandable and usable reporting, which has the capacity to support parental choice, commissioning of services and quality improvement processes. The ECES collected information on how the results of the accreditation and inspection processes are made available to parents and others, and what use is made of the results to inform the development of policy and practice in the study countries (Tables 31 and Table 32).

Table 31: Reporting of results of accreditation of settings for children aged 0 to 3 years (ECED) and children aged 3 to the start of primary school (PPE)

\begin{tabular}{|c|c|c|c|c|c|c|c|c|c|}
\hline \multirow[b]{2}{*}{ Country } & \multirow[b]{2}{*}{ Level } & \multicolumn{8}{|c|}{ Reporting process of accreditation } \\
\hline & & 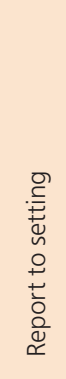 & 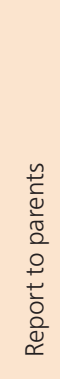 & 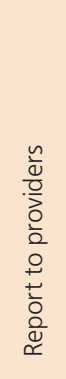 & 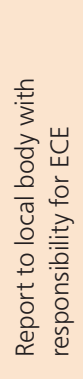 & 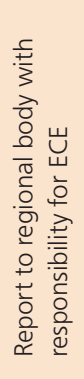 & 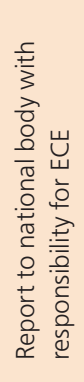 & 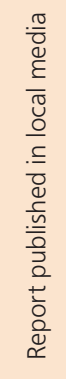 & 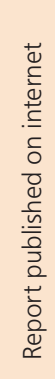 \\
\hline \multirow[t]{2}{*}{ Chile } & ECED & $\bullet$ & ○ & $\bullet$ & O & $\bullet$ & $\bullet$ & O & $\bullet$ \\
\hline & PPE & $\bullet$ & ○ & $\bullet$ & O & O & $\bullet$ & O & $\bullet$ \\
\hline \multirow[t]{2}{*}{ Czech Republic } & ECED & $\mathrm{n} / \mathrm{a}$ & $\mathrm{n} / \mathrm{a}$ & $\mathrm{n} / \mathrm{a}$ & $n / a$ & $\mathrm{n} / \mathrm{a}$ & $n / a$ & $\mathrm{n} / \mathrm{a}$ & $\mathrm{n} / \mathrm{a}$ \\
\hline & PPE & O & O & O & O & O & O & O & ○ \\
\hline \multirow[t]{2}{*}{ Denmark $^{a}$} & ECED & $n / a$ & $\mathrm{n} / \mathrm{a}$ & $\mathrm{n} / \mathrm{a}$ & $\mathrm{n} / \mathrm{a}$ & $\mathrm{n} / \mathrm{a}$ & $n / a$ & $\mathrm{n} / \mathrm{a}$ & $\mathrm{n} / \mathrm{a}$ \\
\hline & PPE & $\mathrm{n} / \mathrm{a}$ & $\mathrm{n} / \mathrm{a}$ & $\mathrm{n} / \mathrm{a}$ & $n / a$ & $\mathrm{n} / \mathrm{a}$ & $\mathrm{n} / \mathrm{a}$ & $\mathrm{n} / \mathrm{a}$ & $\mathrm{n} / \mathrm{a}$ \\
\hline \multirow[t]{2}{*}{ Estonia } & ECED & $\bullet$ & 0 & $\bullet$ & $\bullet$ & O & $\bullet$ & $\bullet$ & $\bullet$ \\
\hline & PPE & $\bullet$ & 0 & $\bullet$ & $\bullet$ & O & $\bullet$ & $\bullet$ & $\bullet$ \\
\hline \multirow[t]{2}{*}{ Italy } & ECED & $\bullet$ & 0 & $\bullet$ & $\bullet$ & 0 & 0 & 0 & 0 \\
\hline & PPE & $\bullet$ & 0 & $\bullet$ & 0 & $\bullet$ & 0 & 0 & 0 \\
\hline \multirow[t]{2}{*}{ Poland } & ECED & $\bullet$ & 0 & 0 & $\bullet$ & 0 & 0 & 0 & 0 \\
\hline & PPE & $\bullet$ & 0 & O & 0 & 0 & O & 0 & $\bullet$ \\
\hline \multirow{2}{*}{$\begin{array}{l}\text { Russian } \\
\text { Federation }\end{array}$} & ECED & $\mathrm{n} / \mathrm{a}$ & $\mathrm{n} / \mathrm{a}$ & $\mathrm{n} / \mathrm{a}$ & $\mathrm{n} / \mathrm{a}$ & $\mathrm{n} / \mathrm{a}$ & $\mathrm{n} / \mathrm{a}$ & $\mathrm{n} / \mathrm{a}$ & $\mathrm{n} / \mathrm{a}$ \\
\hline & PPE & $n / a$ & $\mathrm{n} / \mathrm{a}$ & $n / a$ & $n / a$ & $\mathrm{n} / \mathrm{a}$ & $n / a$ & $n / a$ & $\mathrm{n} / \mathrm{a}$ \\
\hline \multirow[t]{2}{*}{ United States } & ECED & $\bullet$ & $\bullet$ & $\bullet$ & $\bullet$ & $\bullet$ & $\bullet$ & 0 & $\bullet$ \\
\hline & PPE & $\bullet$ & $\bullet$ & $\bullet$ & $\bullet$ & $\bullet$ & $\bullet$ & 0 & $\bullet$ \\
\hline
\end{tabular}

Key:

- Yes, reporting occurs.

- No, reporting does not occur.

n/a Not applicable, as no accreditation exists.

Country Specific Note:

a In Denmark any reports on a setting must be approved by the local community. 
The most frequently reported recipient of accreditation results in the study countries are the settings themselves and those who run the settings, namely the providers (Table 31). Reporting to the local body with responsibility for ECE and reporting to parents are also frequently indicated. Four countries also publish the results more widely through the internet. This evidence suggests that accreditation is seen as an important marker of the quality of the setting and that interested stakeholders are able to access the accreditation reports.

Table 32: Reporting of results of inspection of settings for children aged 0-3 years (ECED) and children aged 3 to the start of primary school (PPE)

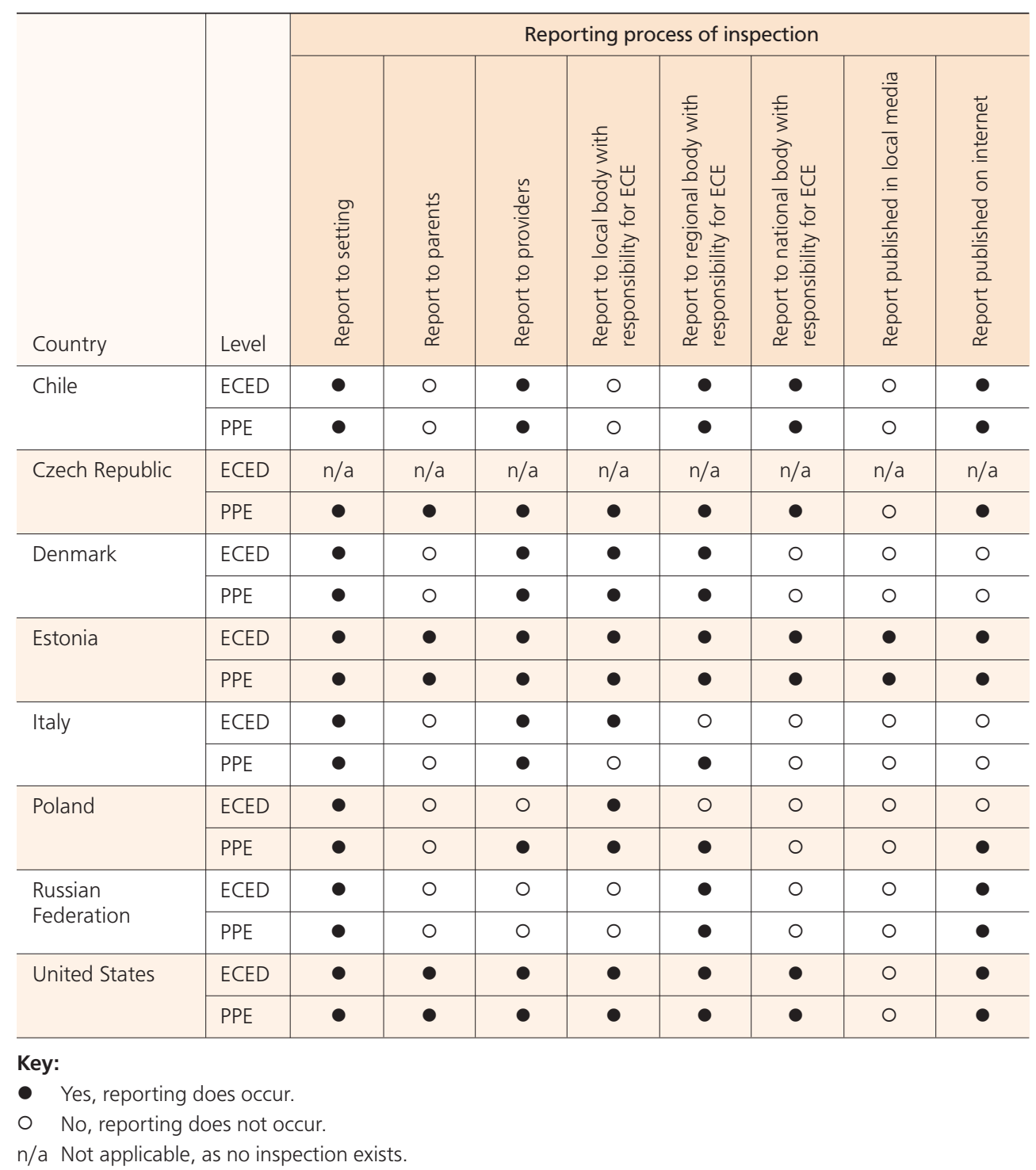

The reporting of inspection results is similar to accreditation, but with a wider range of reporting recipients (Table 32). Again, the most frequently reported recipient of inspection results in the study countries are the settings themselves, but the regional bodies with responsibility for ECE may also receive reports, as do those who run the settings, i.e. the providers. Reporting to parents is reported less frequently, though four countries use the internet to disseminate inspection results. This evidence suggests that accreditation is seen as an important marker of the quality of the setting, and that interested stakeholders are able to access the accreditation reports. It seems that all 
the study countries are attempting to be transparent about their quality assessment and assurance results, and are seeking to promote their quality to wider audiences through the internet. An alternative view is espoused in Poland, where it is noted that surveillance is generally conceived of as bureaucratic, and so results of inspections are not made public and given only to those directly concerned and to judiciary authorities where needed.

Accreditation and inspection reports usually include some indication of areas for further development, and are often viewed as part of a system of continuous review and improvement of policy and practice. The ECES explored how accreditation and inspection reports are used in the study countries to inform the development of policy and practice.

Table 33: Use of accreditation results of settings to inform the development of policy and practice in settings for children aged 0-3 years (ECED) and children aged 3 to the start of primary school (PPE)

\begin{tabular}{|c|c|c|c|c|c|c|c|c|c|c|}
\hline \multirow[b]{2}{*}{ Country } & \multirow[b]{2}{*}{ Level } & \multicolumn{9}{|c|}{ Use of accreditation reports } \\
\hline & & 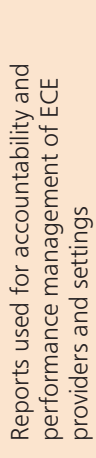 & 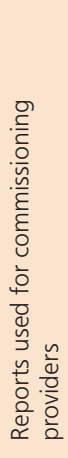 & 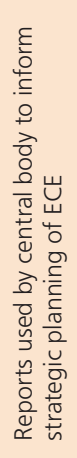 & 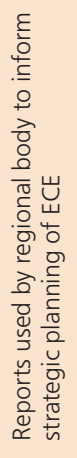 & 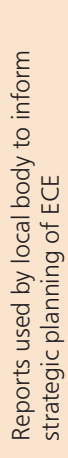 & 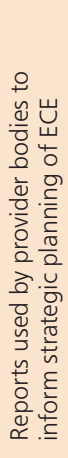 & 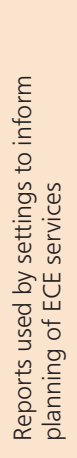 & 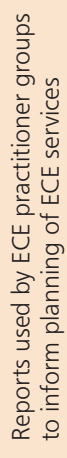 & 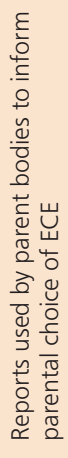 \\
\hline \multirow[t]{2}{*}{ Chile } & ECED & O & $\bullet$ & O & O & O & O & O & O & O \\
\hline & PPE & $\bullet$ & $\bullet$ & O & O & O & $\bullet$ & $\bullet$ & O & O \\
\hline \multirow[t]{2}{*}{ Czech Republic } & ECED & $\mathrm{n} / \mathrm{a}$ & $\mathrm{n} / \mathrm{a}$ & $\mathrm{n} / \mathrm{a}$ & $\mathrm{n} / \mathrm{a}$ & $\mathrm{n} / \mathrm{a}$ & $\mathrm{n} / \mathrm{a}$ & $\mathrm{n} / \mathrm{a}$ & $\mathrm{n} / \mathrm{a}$ & $\mathrm{n} / \mathrm{a}$ \\
\hline & PPE & O & O & O & O & O & O & O & O & O \\
\hline \multirow[t]{2}{*}{ Denmark $^{a}$} & ECED & $\mathrm{n} / \mathrm{a}$ & $\mathrm{n} / \mathrm{a}$ & $\mathrm{n} / \mathrm{a}$ & $\mathrm{n} / \mathrm{a}$ & $\mathrm{n} / \mathrm{a}$ & $\mathrm{n} / \mathrm{a}$ & $\mathrm{n} / \mathrm{a}$ & $\mathrm{n} / \mathrm{a}$ & $\mathrm{n} / \mathrm{a}$ \\
\hline & PPE & $\mathrm{n} / \mathrm{a}$ & $\mathrm{n} / \mathrm{a}$ & $\mathrm{n} / \mathrm{a}$ & $\mathrm{n} / \mathrm{a}$ & $\mathrm{n} / \mathrm{a}$ & $\mathrm{n} / \mathrm{a}$ & $\mathrm{n} / \mathrm{a}$ & $\mathrm{n} / \mathrm{a}$ & $\mathrm{n} / \mathrm{a}$ \\
\hline \multirow[t]{2}{*}{ Estonia } & ECED & $\bullet$ & $\bullet$ & $\bullet$ & $\bullet$ & $\bullet$ & $\bullet$ & $\bullet$ & $\bullet$ & $\bullet$ \\
\hline & PPE & - & - & - & ○ & $\bullet$ & - & - & ○ & - \\
\hline \multirow[t]{2}{*}{ Italy } & ECED & $\bullet$ & O & O & O & O & O & $\bullet$ & O & O \\
\hline & PPE & O & O & O & O & O & O & O & O & O \\
\hline \multirow[t]{2}{*}{ Poland } & ECED & O & O & O & O & $\bullet$ & O & O & O & O \\
\hline & PPE & O & O & $\bullet$ & $\bullet$ & O & O & O & O & O \\
\hline \multirow{2}{*}{$\begin{array}{l}\text { Russian } \\
\text { Federation }\end{array}$} & ECED & $\mathrm{n} / \mathrm{a}$ & $\mathrm{n} / \mathrm{a}$ & $n / a$ & $\mathrm{n} / \mathrm{a}$ & $n / a$ & $\mathrm{n} / \mathrm{a}$ & $\mathrm{n} / \mathrm{a}$ & $\mathrm{n} / \mathrm{a}$ & $\mathrm{n} / \mathrm{a}$ \\
\hline & PPE & $\mathrm{n} / \mathrm{a}$ & $\mathrm{n} / \mathrm{a}$ & $\mathrm{n} / \mathrm{a}$ & $\mathrm{n} / \mathrm{a}$ & $\mathrm{n} / \mathrm{a}$ & $\mathrm{n} / \mathrm{a}$ & $\mathrm{n} / \mathrm{a}$ & $\mathrm{n} / \mathrm{a}$ & $\mathrm{n} / \mathrm{a}$ \\
\hline \multirow[t]{2}{*}{ United States } & ECED & $\bullet$ & • & - & - & - & - & $\bullet$ & $\bullet$ & - \\
\hline & PPE & $\bullet$ & - & • & $\bullet$ & $\bullet$ & $\bullet$ & $\bullet$ & $\bullet$ & - \\
\hline
\end{tabular}

Key:

- Yes, results are used.

O No, results are not used.

$\mathrm{n} / \mathrm{a}$ Not applicable, as there is no accreditation to report.

Country Specific Note:

a In Denmark, any reports on a setting must be approved by the local community. 
All countries that received accreditation results used them in a variety of ways to inform policy and practice (Table 33). This was particularly evident in Estonia and the United States. The most frequently reported uses of the results were to inform accountability and performance management processes (Chile, Estonia, Italy and the United States); to use them in commissioning processes (Chile, Estonia and the United States); and to inform planning of services (Chile, Estonia, Italy [ECED] and the United States).

Table 34: Use of inspection results of settings to inform the development of policy and practice in settings for children aged 0-3 years (ECED) and children aged 3 to the start of primary school (PPE)

\begin{tabular}{|c|c|c|c|c|c|c|c|c|c|c|}
\hline \multirow[b]{2}{*}{ Country } & \multirow[b]{2}{*}{ Level } & \multicolumn{9}{|c|}{ Use of inspection reports } \\
\hline & & 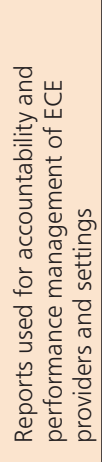 & 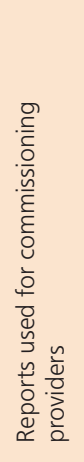 & 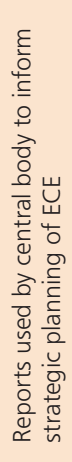 & 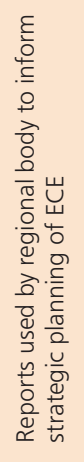 & 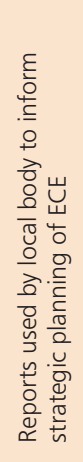 & 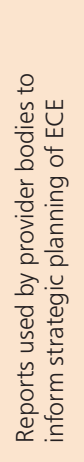 & 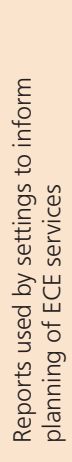 & 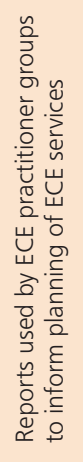 & 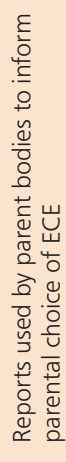 \\
\hline \multirow[t]{2}{*}{ Chile } & ECED & O & $\bullet$ & O & O & O & O & O & O & O \\
\hline & PPE & $\bullet$ & $\bullet$ & O & O & O & $\bullet$ & $\bullet$ & O & O \\
\hline \multirow[t]{2}{*}{ Czech Republic } & ECED & $n / a$ & $n / a$ & $\mathrm{n} / \mathrm{a}$ & $\mathrm{n} / \mathrm{a}$ & $\mathrm{n} / \mathrm{a}$ & $n / a$ & $\mathrm{n} / \mathrm{a}$ & $\mathrm{n} / \mathrm{a}$ & $\mathrm{n} / \mathrm{a}$ \\
\hline & PPE & $\bullet$ & $\bullet$ & $\bullet$ & $\bullet$ & $\bullet$ & $\bullet$ & $\bullet$ & $\bullet$ & $\bullet$ \\
\hline \multirow[t]{2}{*}{ Denmark } & ECED & $\bullet$ & O & O & O & O & 0 & O & $\bullet$ & O \\
\hline & PPE & $\bullet$ & 0 & 0 & O & O & O & 0 & $\bullet$ & O \\
\hline \multirow[t]{2}{*}{ Estonia } & ECED & $\bullet$ & $\bullet$ & $\bullet$ & $\bullet$ & $\bullet$ & $\bullet$ & $\bullet$ & $\bullet$ & $\bullet$ \\
\hline & PPE & $\bullet$ & $\bullet$ & $\bullet$ & $\bullet$ & $\bullet$ & $\bullet$ & $\bullet$ & $\bullet$ & $\bullet$ \\
\hline \multirow[t]{2}{*}{ Italy } & ECED & $\bullet$ & 0 & O & 0 & O & O & $\bullet$ & O & O \\
\hline & PPE & $\bullet$ & 0 & O & O & 0 & 0 & $\bullet$ & O & O \\
\hline \multirow[t]{2}{*}{ Poland } & ECED & O & 0 & 0 & 0 & O & 0 & 0 & 0 & 0 \\
\hline & PPE & $\bullet$ & 0 & $\bullet$ & $\bullet$ & $\bullet$ & $\bullet$ & $\bullet$ & $\bullet$ & $\bullet$ \\
\hline \multirow{2}{*}{$\begin{array}{l}\text { Russian } \\
\text { Federation }\end{array}$} & ECED & $\bullet$ & 0 & o & $\bullet$ & $\bullet$ & 0 & $\bullet$ & o & $\bullet$ \\
\hline & PPE & $\bullet$ & 0 & 0 & $\bullet$ & $\bullet$ & 0 & $\bullet$ & O & $\bullet$ \\
\hline \multirow[t]{2}{*}{ United States } & ECED & $\bullet$ & $\bullet$ & $\bullet$ & $\bullet$ & $\bullet$ & $\bullet$ & $\bullet$ & $\bullet$ & $\bullet$ \\
\hline & PPE & $\bullet$ & $\bullet$ & $\bullet$ & $\bullet$ & $\bullet$ & $\bullet$ & $\bullet$ & $\bullet$ & $\bullet$ \\
\hline
\end{tabular}

Key:

- Yes, results are used.

No, results are not used.

$\mathrm{n} / \mathrm{a}$ Not applicable, as no inspection occurs. 
All countries that have inspection results used them in a variety of ways to inform policy and practice (Table 34). This was particularly evident in Estonia and the United States. The most frequently reported uses of the results were to inform accountability and performance management processes (Chile, the Czech Republic, Estonia, Italy, Poland, the Russian Federation and the United States), planning of services (Chile, the Czech Republic, Estonia, Italy, Poland and the United States), and parental choices (the Czech Republic, Estonia, Poland, the Russian Federation and the United States).

\section{Summary Finding 31}

All the countries that have accreditation and inspection processes promote the results to inform the further development of quality in settings and to establish quality credentials with key bodies, as reflected in the reports. Among the study countries, there is clear evidence of genuine effort to be transparent and accountable to interested bodies and individuals, through by reporting development planning, quality improvement, performance management, knowledge creation and transfer, and also documented achievements.

Open Access This chapter is distributed under the terms of the Creative Commons AttributionNonCommercial 4.0 International License (http://creativecommons.org/licenses/by-nc/4.0/), which permits any noncommercial use, duplication, adaptation, distribution and reproduction in any medium or format, as long as you give appropriate credit to the original author(s) and the source, provide a link to the Creative Commons license and indicate if changes were made.

The images or other third party material in this chapter are included in the works Creative Commons license, unless indicated otherwise in the credit line; if such material is not included in the works Creative Commons license and the respective action is not permitted by statutory regulation, users will need to obtain permission from the license holder to duplicate, adapt or reproduce the material. 


\section{CHAPTER 8:}

\section{Expectations for Child Outcomes, Assessment and Reporting}

This chapter of the report describes expectations for child outcomes for children from birth to three years (ECED) and children from age three to start of primary schooling (PPE). It sets out whether and how these outcomes are assessed and recorded, and how child outcomes data are used to support the development of policy and practice. Within and between country similarities and variations in child outcomes expectations and practice will be highlighted.

\section{Expectations for Child Outcomes}

Expectations of outcomes for children will differ according to the age of the child, the overall policy aims of the country and the curriculum offered by the provider, and the cultural expectations around early childhood as a formative period in a child's life (OECD, 2012b). Studies have shown that those countries which emphasize ECE as providing a preparation for school generally favor a narrower set of academic outcomes for children (such as literacy and numeracy). Other countries focus on a child's value base and preparation to participate as an active citizen, or on a child's generic or executive functioning skills as a learner, or on a child's general health and wellbeing, and social and emotional adjustment (OECD, 2006, 2012a; Pascal, \& Bertram, 2012). Despite this diversity, many countries have shared expectations for ECE that focus particularly on nurturing children's social and emotional, physical and language development. However, some countries also focus more specifically on developing children's early literacy and numeracy skills, with the intention of ensuring what might be termed "school readiness."

The outcomes that any ECE setting works toward may be affected by its philosophical approach or the culture of the community it serves. Parents' expectations of their children's achievements may also impact on the outcomes a setting aims to achieve. For example, Li and Rao (2005) reported that in Hong Kong and Singapore there was a demand from parents for greater emphasis to be given to pre-academic skills than was mandated by the national authorities.

The ECES gathered information from the study countries about nationally, regionally or locally stated expectations for child outcomes in different areas of learning and development (Table 35).

Five of the study countries (Chile, Denmark, Estonia, the Russian Federation and the United States) have explicit expectations for child outcomes for children from birth to three years (Table 35). The Czech Republic, Italy and Poland have no explicitly stated expectations about child outcomes for these younger children. All the study countries have explicit expectations for child outcomes for children aged three years to primary school age (PPE). This evidence indicates that the study countries see early childhood as an important stage in children's learning and development, and expect their services to contribute to enhancing this, particularly as children move towards primary school. 
Table 35: Expectations for child outcomes in different areas of learning and development for children aged 0-3 years (ECED) and children aged 3 to the start of primary school (PPE)

\begin{tabular}{|c|c|c|c|c|c|c|c|c|c|c|c|c|c|c|}
\hline \multirow[b]{2}{*}{ Country } & \multirow[b]{2}{*}{ Level } & \multicolumn{13}{|c|}{ Explicit expectations for child outcomes in areas of learning } \\
\hline & & 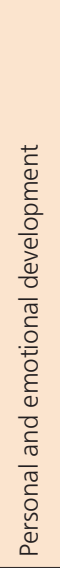 & 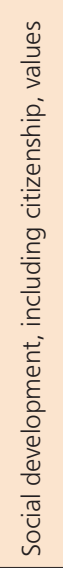 & 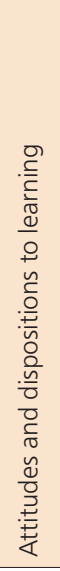 & 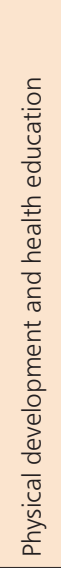 & 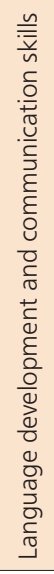 & 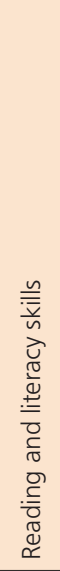 & 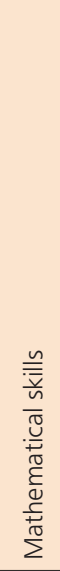 & 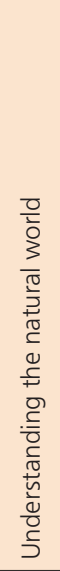 & 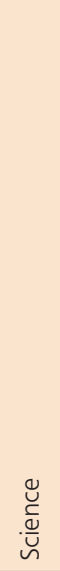 & 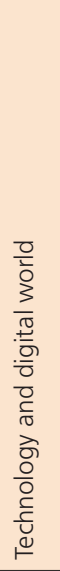 & 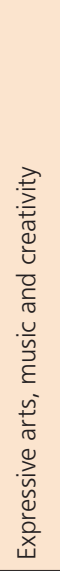 & 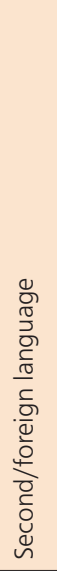 & 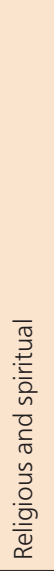 \\
\hline \multirow[t]{2}{*}{ Chile } & ECED & $\bullet$ & $\bullet$ & $\bullet$ & $\bullet$ & $\bullet$ & $\bullet$ & $\bullet$ & $\bullet$ & O & 0 & $\bullet$ & 0 & O \\
\hline & PPE & $\bullet$ & $\bullet$ & $\bullet$ & $\bullet$ & $\bullet$ & $\bullet$ & $\bullet$ & $\bullet$ & O & 0 & $\bullet$ & O & O \\
\hline \multirow[t]{2}{*}{ Czech Republic } & ECED & $\mathrm{n} / \mathrm{a}$ & $\mathrm{n} / \mathrm{a}$ & $\mathrm{n} / \mathrm{a}$ & $n / a$ & $n / a$ & $\mathrm{n} / \mathrm{a}$ & $\mathrm{n} / \mathrm{a}$ & $n / a$ & $n / a$ & $\mathrm{n} / \mathrm{a}$ & $n / a$ & $n / a$ & $n / a$ \\
\hline & PPE & $\bullet$ & $\bullet$ & $\bullet$ & $\bullet$ & $\bullet$ & $\bullet$ & $\bullet$ & $\bullet$ & $\bullet$ & $\bullet$ & $\bullet$ & 0 & 0 \\
\hline \multirow[t]{2}{*}{ Denmark } & ECED & $\bullet$ & $\bullet$ & $\bullet$ & $\bullet$ & $\bullet$ & $\bullet$ & $\bullet$ & $\bullet$ & $\bullet$ & $\bullet$ & $\bullet$ & 0 & 0 \\
\hline & PPE & $\bullet$ & $\bullet$ & $\bullet$ & $\bullet$ & $\bullet$ & $\bullet$ & $\bullet$ & $\bullet$ & $\bullet$ & $\bullet$ & $\bullet$ & O & O \\
\hline \multirow[t]{2}{*}{ Estonia } & ECED & $\bullet$ & $\bullet$ & $\bullet$ & $\bullet$ & $\bullet$ & $\bullet$ & $\bullet$ & $\bullet$ & $\bullet$ & $\bullet$ & $\bullet$ & O & O \\
\hline & PPE & $\bullet$ & $\bullet$ & $\bullet$ & $\bullet$ & $\bullet$ & $\bullet$ & $\bullet$ & $\bullet$ & $\bullet$ & $\bullet$ & $\bullet$ & $\bullet$ & O \\
\hline \multirow[t]{2}{*}{ Italy } & ECED & $n / a$ & $\mathrm{n} / \mathrm{a}$ & $\mathrm{n} / \mathrm{a}$ & $n / a$ & $n / a$ & $\mathrm{n} / \mathrm{a}$ & $\mathrm{n} / \mathrm{a}$ & $n / a$ & $n / a$ & $\mathrm{n} / \mathrm{a}$ & $n / a$ & $n / a$ & $\mathrm{n} / \mathrm{a}$ \\
\hline & PPE & $\bullet$ & $\bullet$ & $\bullet$ & $\bullet$ & $\bullet$ & $\bullet$ & $\bullet$ & $\bullet$ & $\bullet$ & $\bullet$ & $\bullet$ & $\bullet$ & $\bullet$ \\
\hline \multirow[t]{2}{*}{ Poland } & ECED & $\mathrm{n} / \mathrm{a}$ & $\mathrm{n} / \mathrm{a}$ & $\mathrm{n} / \mathrm{a}$ & $\mathrm{n} / \mathrm{a}$ & $\mathrm{n} / \mathrm{a}$ & $\mathrm{n} / \mathrm{a}$ & $\mathrm{n} / \mathrm{a}$ & $\mathrm{n} / \mathrm{a}$ & $\mathrm{n} / \mathrm{a}$ & $\mathrm{n} / \mathrm{a}$ & $\mathrm{n} / \mathrm{a}$ & $\mathrm{n} / \mathrm{a}$ & $\mathrm{n} / \mathrm{a}$ \\
\hline & PPE & $\bullet$ & $\bullet$ & $\bullet$ & $\bullet$ & $\bullet$ & $\bullet$ & $\bullet$ & $\bullet$ & $\bullet$ & $\bullet$ & $\bullet$ & 0 & O \\
\hline \multirow{2}{*}{$\begin{array}{l}\text { Russian } \\
\text { Federation }\end{array}$} & ECED & $\bullet$ & 0 & 0 & $\bullet$ & $\bullet$ & 0 & O & 0 & 0 & 0 & 0 & 0 & O \\
\hline & PPE & $\bullet$ & $\bullet$ & $\bullet$ & $\bullet$ & $\bullet$ & 0 & 0 & $\bullet$ & 0 & 0 & 0 & 0 & 0 \\
\hline \multirow[t]{2}{*}{ United States } & ECED & $\bullet$ & $\bullet$ & $\bullet$ & $\bullet$ & $\bullet$ & $\bullet$ & $\bullet$ & $\bullet$ & $\bullet$ & 0 & $\bullet$ & 0 & 0 \\
\hline & PPE & $\bullet$ & $\bullet$ & $\bullet$ & $\bullet$ & $\bullet$ & $\bullet$ & $\bullet$ & $\bullet$ & $\bullet$ & $\bullet$ & $\bullet$ & 0 & 0 \\
\hline
\end{tabular}

Key:

- Yes, there are expectations for child outcomes

O No, there are not expectations for child outcomes in this area.

$\mathrm{n} / \mathrm{a}$ There are no stated expectations for child outcomes during this phase.

The data indicate a broad range of learning and development expectations in participating countries throughout this age phase, with all the study countries reflecting the balance in the curriculum that was identified in Chapter 7. In particular, all countries identified expectations for learning in personal, social and emotional development, physical development and health, and language development and communication skills throughout this age phase. For example, Chile reported that they have a particular focus on three main areas of learning for children under the age of three years: social and personal development; communication; and relation with the cultural and natural environment. Other countries reported a similar focus, and the emphasis was generally on promoting a wide range of learning outcomes. The range of expectations identified 
also reflects a balance between cognitive and non-cognitive areas of learning, with more "subject based" learning outcomes expected as the children move into pre-primary education.

\section{Summary Finding 32}

The study countries take rather a broad view of children's learning and the outcomes that early education settings might support, including a range of cognitive and non-cognitive learning outcomes, and do not focus on a narrow range of children's learning outcomes in this phase of education.

\section{Assessment Methods}

A recent paper by the World Bank (2013) defined assessment as the process of gathering and evaluating information on what students know, understand, and can do in order to make an informed decision about next steps in the educational process. Methods can be as simple as oral questioning and response, or as complex as computer-adaptive testing models based on multifaceted scoring algorithms and learning progressions. Decisions based on the results may vary from how to design system-wide programs to improve teaching and learning in schools, to identifying next steps in classroom teaching, to determining which applicants should be admitted to a setting. An assessment system is a group of policies, structures, practices, and tools for generating and using information on student learning and achievement. The authors of the World Bank paper defined effective assessment systems as those that provide information of sufficient quality and quantity to meet stakeholder information and decision-making needs in support of improved education quality and student learning. The paper argued that meeting these information and decision-making needs in a way that has the support of key political and other groups in society will contribute to the longer term sustainability and effectiveness of the assessment system.

Recent policy agendas of governments, international organizations, and other stakeholders increasingly highlight the importance of assessment for monitoring and improving student learning and achievement levels, and the concomitant need to develop strong systems for student assessment (McKinsey, 2007). This recognition is linked to growing evidence that many of the benefits of education (cultural, economic, and social) accrue to society only when learning occurs (OECD, 2010). For example, an increase of one standard deviation in scores on international assessments of reading and mathematics achievement levels has been linked to a $2 \%$ increase in annual growth rates of gross domestic product per capita (OECD, 2012a).

Over the last twenty years, many countries have started implementing assessment exercises or building on existing assessment systems (OECD, 2012b). In addition, there has been huge growth in the number of countries participating in international comparative assessment exercises such as the Trends in International Mathematics and Science Study (TIMSS) and the Program for International Student Assessment (PISA), but few have tackled the challenge of assessing children's learning and development outcomes in ECE, despite the recognition of similar system demands and challenges. This means that cross-national assessments of learning outcomes for younger children are rare and underdeveloped, being controversial and perceived as difficult to achieve. 
For example, Denmark reported that the recent introduction of testing of language development for under-threes has been criticized because it takes too much of the pedagogue's time and it is considered to be unhealthy for small children to be tested. The Russian Federation also stated that they believed child outcomes cannot be directly assessed, and that they do not form the basis of identifying the real achievements of children.

Given the wider dialogue about the value, purpose and ethics of assessing young children, the ECES gathered evidence on the existence of child assessments for children from birth to primary school entry in the study countries and the assessment methods used (Tables 36 and 37).

Table 36: Existence of national or subnational child assessments in different areas of learning and development for children aged 0-3 years (ECED) and children aged 3 to the start of primary school (PPE)

\begin{tabular}{|c|c|c|c|c|c|c|c|c|c|c|c|c|c|c|c|}
\hline \multirow[b]{2}{*}{ Country ${ }^{a, b}$} & \multirow[b]{2}{*}{ Level } & \multicolumn{14}{|c|}{ Existence of national or typical subnational assessments of children in different areas of learning } \\
\hline & & 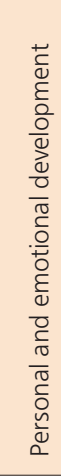 & 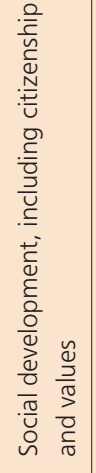 & 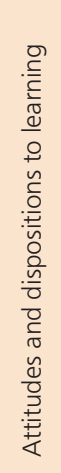 & 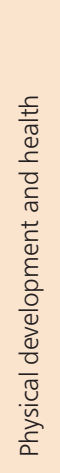 & 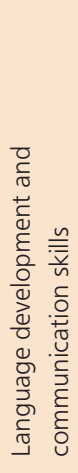 & 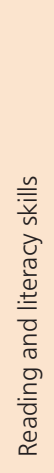 & 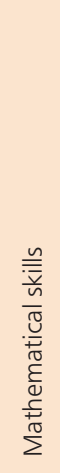 & 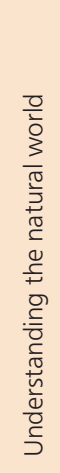 & 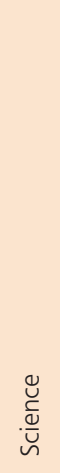 & 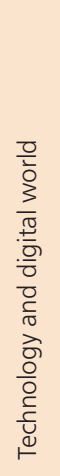 & 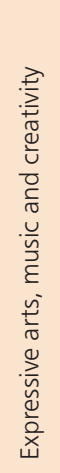 & 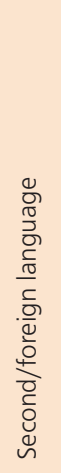 & 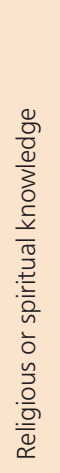 & 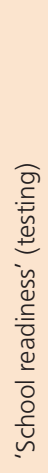 \\
\hline \multirow[t]{2}{*}{ Chile } & ECED & $\bullet$ & $\bullet$ & ○ & $\bullet$ & $\bullet$ & $\bullet$ & $\bullet$ & O & ○ & O & O & O & O & O \\
\hline & PPE & $\bullet$ & $\bullet$ & O & $\bullet$ & $\bullet$ & $\bullet$ & $\bullet$ & 0 & O & O & 0 & O & O & 0 \\
\hline \multirow[t]{2}{*}{ Czech Republic } & ECED & $n / a$ & $n / a$ & $n / a$ & $n / a$ & $n / a$ & $n / a$ & $n / a$ & $\mathrm{n} / \mathrm{a}$ & $\mathrm{n} / \mathrm{a}$ & $\mathrm{n} / \mathrm{a}$ & $\mathrm{n} / \mathrm{a}$ & $\mathrm{n} / \mathrm{a}$ & $\mathrm{n} / \mathrm{a}$ & $\mathrm{n} / \mathrm{a}$ \\
\hline & PPE & $\bullet$ & $\bullet$ & $\bullet$ & $\bullet$ & $\bullet$ & $\bullet$ & $\bullet$ & $\bullet$ & $\bullet$ & $\bullet$ & $\bullet$ & O & O & 0 \\
\hline \multirow[t]{2}{*}{ Estonia } & ECED & $\bullet$ & $\bullet$ & $\bullet$ & $\bullet$ & $\bullet$ & $\bullet$ & $\bullet$ & $\bullet$ & $\bullet$ & $\bullet$ & $\bullet$ & O & O & 0 \\
\hline & PPE & $\bullet$ & $\bullet$ & $\bullet$ & $\bullet$ & $\bullet$ & $\bullet$ & $\bullet$ & $\bullet$ & $\bullet$ & $\bullet$ & $\bullet$ & $\bullet$ & O & $\bullet$ \\
\hline \multirow[t]{2}{*}{ Poland } & ECED & $\mathrm{n} / \mathrm{a}$ & $n / a$ & $\mathrm{n} / \mathrm{a}$ & $\mathrm{n} / \mathrm{a}$ & $\mathrm{n} / \mathrm{a}$ & $\mathrm{n} / \mathrm{a}$ & $\mathrm{n} / \mathrm{a}$ & $\mathrm{n} / \mathrm{a}$ & $n / a$ & $\mathrm{n} / \mathrm{a}$ & $\mathrm{n} / \mathrm{a}$ & $n / a$ & $\mathrm{n} / \mathrm{a}$ & $\mathrm{n} / \mathrm{a}$ \\
\hline & PPE & $\bullet$ & $\bullet$ & $\bullet$ & $\bullet$ & $\bullet$ & $\bullet$ & $\bullet$ & $\bullet$ & $\bullet$ & $\bullet$ & $\bullet$ & 0 & O & $\bullet$ \\
\hline
\end{tabular}

Key:

- Yes, rhere are national or typical subnational child assessments in this learning area.

O No, there are no national or typical subnational child assessments in this learning area.

n/a There are no national or typical subnational child assessments during this phase.

\section{Country specific notes:}

a Denmark reported that it does not conduct national assessments of children under the age of three years, and this is not required by national law, but that some local communities do require centers to test the children. Research has shown that at subnational level all the suggested areas of learning in the above Table can be assessed

${ }^{b}$ Italy reported that only local assessments exist and are not generalized to the entire population of a given region of children in ISCED 0 . Several universities are working on children's assessments (mainly with observations, checklists, tasks and play), but no one system is used at regional level. A potentially regional system based upon the EDI (Early Development Instrument) has been recently piloted at PPE level in Emilia Romagna region. 
Four of the eight study countries conducted formal child assessments during ISCED Level 0 at a national or subnational level, including Chile, the Czech Republic, Estonia and Poland (Table 36). Of these countries, only Chile and Estonia reported that underthrees are formally assessed in early childhood centers. Denmark reported that there are no national assessments of children during this age phase, but that some local communities do require centers to test their children. Denmark, Italy, the Russian Federation and the United States reported that they do not formally assess the children at either ECED or pre-primary level.

In the four countries that conduct formal assessments, the areas of learning assessed included personal and emotional development, social development, physical development, and health, language and communication development, reading and literacy development, and mathematical development. This suggests that assessments are used to capture a broad range of learning outcomes, which include both cognitive and non-cognitive competencies (executive learning skills) and are not narrowly focused on areas for "school readiness" such as literacy and mathematics.

The methods of assessment used to capture children's learning and development outcomes in the study countries were also explored (Table 37).

Table 37: Assessment methods used for children aged 0-3 years (ECED) and children aged 3 to the start of primary school (PPE)

\begin{tabular}{|c|c|c|c|c|c|}
\hline \multirow[b]{2}{*}{ Country } & \multirow[b]{2}{*}{ Level } & \multicolumn{4}{|c|}{ Assessment methods used } \\
\hline & & $\begin{array}{l}\text { Practitioner } \\
\text { observations }\end{array}$ & $\begin{array}{l}\text { Standardized } \\
\text { tasks }\end{array}$ & $\begin{array}{l}\text { Standardized } \\
\text { tests }\end{array}$ & $\begin{array}{c}\text { Mixture of } \\
\text { methods }\end{array}$ \\
\hline \multirow[t]{2}{*}{ Chile } & ECED & O & $\bullet$ & $\bullet$ & O \\
\hline & PPE & O & $\bullet$ & $\bullet$ & O \\
\hline \multirow[t]{2}{*}{ Czech Republic } & ECED & $\mathrm{n} / \mathrm{a}$ & $\mathrm{n} / \mathrm{a}$ & $\mathrm{n} / \mathrm{a}$ & $\mathrm{n} / \mathrm{a}$ \\
\hline & PPE & O & O & O & O \\
\hline \multirow[t]{2}{*}{ Denmark a } & ECED & o & 0 & O & $\bullet$ \\
\hline & PPE & O & O & O & $\bullet$ \\
\hline \multirow[t]{2}{*}{ Estonia } & ECED & $\bullet$ & 0 & 0 & O \\
\hline & PPE & $\bullet$ & $\bullet$ & $\bullet$ & $\bullet$ \\
\hline \multirow[t]{2}{*}{ Poland } & ECED & $n / a$ & $n / a$ & $n / a$ & $\mathrm{n} / \mathrm{a}$ \\
\hline & PPE & $\bullet$ & O & ○ & $\bullet$ \\
\hline
\end{tabular}

Key:

- Yes, this assessment method is used.

O No, this assessment method is not used.

$\mathrm{n} / \mathrm{a}$ There are no national child assessments during this phase.

Country specific note:

a Some communities in Denmark require centers to test children, however, it is not required by law. Different methods for assessments are used by local communities, including observations, tasks and tests.

In the countries that have national assessments, practitioner observations are used in Estonia and Poland (PPE only); standardized tasks are used in Chile and Estonia (PPE only); and standardized tests are used in Chile and Estonia (PPE only) (Table 37). The evidence also indicates that Estonia and Poland (and Denmark where centers assess) use a mixture of methods to assess children's learning outcomes. 


\section{Summary Finding 33}

National child assessments are not commonly conducted in ECE. The findings reveal that assessments, when conducted, are used in the study countries to capture a broad range of learning outcomes, which include cognitive development, executive functioning and social-emotional development, and are not narrowly focused solely on areas of traditional or perceived "school readiness", such as literacy and mathematics. The methods of assessment used to capture children's learning and development in the study countries are reported to include practitioner observations and standardized tests, with a mixture of methods prevalent.

\section{Reporting of Outcomes Data}

Child outcomes data allow researchers, policymakers, providers and parents to draw clearer conclusions regarding the beneficiaries of ECE, what these benefits and outcomes are, and what conditions enable these outcomes to be achieved. The audiences for these data are varied, and there is a range of reporting mechanisms and processes available, from ICT, internet websites and other mass dissemination mechanisms, to local, faceto-face documentation and feedback, designed to ensure such data are transparent and accessible to children, parents and individual service providers, as well as policymakers. The four study countries that collect child outcomes data provided information on the recipients of the data (Table 38).

Table 38: Recipients of reporting of child outcomes data for children aged 0-3 years (ECED) and children aged 3 to the start of primary school (PPE)

\begin{tabular}{|c|c|c|c|c|c|c|c|c|c|}
\hline \multirow[b]{2}{*}{ Country } & \multirow[b]{2}{*}{ Level } & \multicolumn{8}{|c|}{ Child outcomes data is reported to } \\
\hline & & 号 & 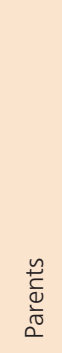 & $\begin{array}{l}\frac{n}{0} \\
\frac{0}{2} \\
\frac{0}{2}\end{array}$ & 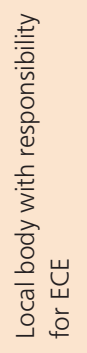 & 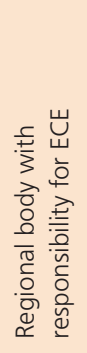 & 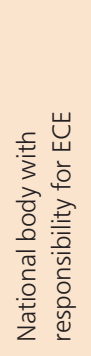 & 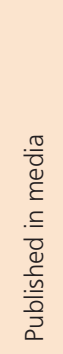 & 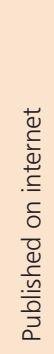 \\
\hline \multirow[t]{2}{*}{ Chile } & ECED & O & O & O & O & O & $\bullet$ & O & $\bullet$ \\
\hline & PPE & O & O & O & O & O & $\bullet$ & O & $\bullet$ \\
\hline \multirow[t]{2}{*}{ Czech Republic } & ECED & $\mathrm{n} / \mathrm{a}$ & $\mathrm{n} / \mathrm{a}$ & $\mathrm{n} / \mathrm{a}$ & $\mathrm{n} / \mathrm{a}$ & $\mathrm{n} / \mathrm{a}$ & $\mathrm{n} / \mathrm{a}$ & $\mathrm{n} / \mathrm{a}$ & $\mathrm{n} / \mathrm{a}$ \\
\hline & PPE & $\bullet$ & $\bullet$ & O & $\bullet$ & $\bullet$ & $\bullet$ & O & $\bullet$ \\
\hline \multirow[t]{2}{*}{ Estonia } & ECED & $\bullet$ & $\bullet$ & O & O & O & O & O & O \\
\hline & PPE & $\bullet$ & - & O & O & O & O & O & O \\
\hline \multirow[t]{2}{*}{ Poland } & ECED & $\mathrm{n} / \mathrm{a}$ & $\mathrm{n} / \mathrm{a}$ & $\mathrm{n} / \mathrm{a}$ & $\mathrm{n} / \mathrm{a}$ & $\mathrm{n} / \mathrm{a}$ & $\mathrm{n} / \mathrm{a}$ & $\mathrm{n} / \mathrm{a}$ & $\mathrm{n} / \mathrm{a}$ \\
\hline & PPE & $\bullet$ & $\bullet$ & $\bullet$ & $\bullet$ & $\bullet$ & $\bullet$ & O & $\bullet$ \\
\hline \multicolumn{10}{|l|}{ Key: } \\
\hline \multicolumn{10}{|c|}{ - Yes, this assessment method is used. } \\
\hline \multicolumn{10}{|c|}{ O No, this assessment method is not used. } \\
\hline
\end{tabular}


The evidence from the four study countries indicates that the data are reported to a range of recipients. In Chile, it is primarily reported to the national bodies with responsibility for ECE and then to the wider public via the internet. The Czech Republic and Poland report this data to a wide range of recipients, including the setting, parents, local and regional bodies with responsibility for ECE, and also to the wider public through the internet. In contrast, settings and parents are the primary recipients in Estonia, as they consider this data to be confidential and so are reluctant to report it more widely.

\section{Summary Finding 34}

The findings indicate that child outcomes data are reported to a wide group of recipients, each of whom can potentially use the data to inform the development of educative practice for young children in the home, in the setting, in the locality, region and country as a whole. The data also indicate that a range of reporting platforms are used from ICT, internet websites and other mass dissemination mechanisms, to local, face-to-face interactions, documentation and feedback.

\section{Use of Child Outcomes Data}

Information about children's outcomes can be used to inform the development of learning for children at individual, cohort and population levels, to monitor ECE system performance for accountability purposes, to direct resources efficiently towards need, to inform program planning and development, or provide information to parents to engage them in their child's learning and to identify any inequality of outcomes delivered by the system for certain groups of the population. The recent global economic crisis and pressure on education funding also emphasizes the need for accountability and "value for money" and for evidence-based policy making, as well as for rating program quality for improvement purposes, highlighting trends in the sector and contributing to parental choice. However, child outcomes data related to early childhood policy is often retrospectively derived from secondary analysis of datasets created for other age groups and purposes, and such limitations lead to uncertain policy making at a national level and to a lack of reliable comparative data at an international level (OECD, 2006; Pascal, \& Bertram, 2012; Pascal et al., 2012).

Given this wider data challenge, the ECES explored how child outcomes data are used to inform policy and practice within the four study countries that collect it (Table 39). 
Table 39: Use of child outcomes data for children aged 0-3 years (ECED) and children aged 3 to the start of primary school (PPE)

\begin{tabular}{|c|c|c|c|c|c|c|c|c|c|c|}
\hline \multirow[b]{2}{*}{ Country } & \multirow[b]{2}{*}{ Level } & \multicolumn{9}{|c|}{$\begin{array}{l}\text { Use of results of national or typical subnational child assessments to } \\
\text { inform the development of ECE policy and practice nationally }\end{array}$} \\
\hline & & 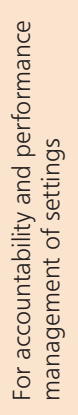 & 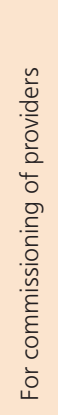 & 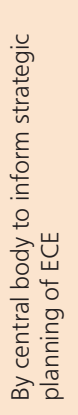 & 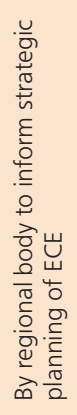 & 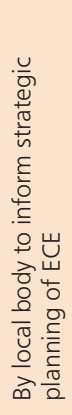 & 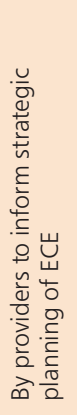 & 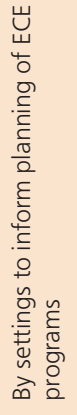 & 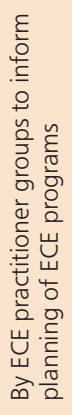 & 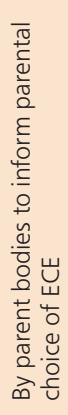 \\
\hline \multirow[t]{2}{*}{ Chile } & ECED & O & 0 & $\bullet$ & O & O & O & O & O & O \\
\hline & PPE & O & 0 & $\bullet$ & 0 & 0 & O & O & O & 0 \\
\hline \multirow[t]{2}{*}{ Czech Republic } & ECED & $\mathrm{n} / \mathrm{a}$ & $\mathrm{n} / \mathrm{a}$ & $\mathrm{n} / \mathrm{a}$ & $\mathrm{n} / \mathrm{a}$ & $\mathrm{n} / \mathrm{a}$ & $n / a$ & $\mathrm{n} / \mathrm{a}$ & $\mathrm{n} / \mathrm{a}$ & $\mathrm{n} / \mathrm{a}$ \\
\hline & PPE & $\bullet$ & $\bullet$ & - & • & - & - & $\bullet$ & $\bullet$ & $\bullet$ \\
\hline \multirow[t]{2}{*}{ Estonia } & ECED & $\bullet$ & ○ & ○ & O & O & O & - & - & O \\
\hline & PPE & $\bullet$ & 0 & O & O & 0 & 0 & $\bullet$ & $\bullet$ & O \\
\hline \multirow[t]{2}{*}{ Poland } & ECED & $\mathrm{n} / \mathrm{a}$ & $\mathrm{n} / \mathrm{a}$ & $\mathrm{n} / \mathrm{a}$ & $\mathrm{n} / \mathrm{a}$ & $\mathrm{n} / \mathrm{a}$ & $\mathrm{n} / \mathrm{a}$ & $\mathrm{n} / \mathrm{a}$ & $\mathrm{n} / \mathrm{a}$ & $\mathrm{n} / \mathrm{a}$ \\
\hline & PPE & $\bullet$ & O & $\bullet$ & $\bullet$ & $\bullet$ & O & O & O & O \\
\hline
\end{tabular}

Key:

- Yes, outcomes data are used for this purpose.

O No, outcomes data are not used for this purpose.

n/a There are no national child assessments during this phase

The evidence reveals that child outcomes data are used very differently in each study country that collects data. In Chile, the child assessment data is primarily used by the central body to inform strategic planning of ECE services. In Estonia, the child assessment data are used for accountability and performance management of settings, and to inform the planning of programs within settings. In this country practitioner groups also use the data to inform the wider planning of programs for the underthrees. The Czech Republic uses the results of child assessments to inform the full range of policies and practice development in pre-primary education, from national strategic planning, through to regional, local system and setting planning. It is also used to inform parental choice. In Poland, the assessment data are used for accountability and performance management, and by regional and local bodies to inform the strategic planning of pre-primary programs. In Poland, parents also have the choice to show their child's assessment to teachers in elementary school if special educational needs are present. 


\section{Summary Finding 35}

The study countries illustrate the potential value of having child outcomes data at a national and subnational level to inform, evaluate and improve system performance, as well as at setting level to inform children's learning plans and setting development. However, few countries reported typical national or typical subnational assessments of children's learning and development for children at different stages in ISCED 0 . The countries that reported having typical assessments reported using the information to inform system performance, as well as at the setting level to inform children's learning plans and setting development. There continues to be hesitancy in some countries (Denmark, Italy and the Russian Federation) to collect and use child outcomes data for ethical, methodological, and administrative reasons.

Open Access This chapter is distributed under the terms of the Creative Commons AttributionNonCommercial 4.0 International License (http://creativecommons.org/licenses/by-nc/4.0/), which permits any noncommercial use, duplication, adaptation, distribution and reproduction in any medium or format, as long as you give appropriate credit to the original author(s) and the source, provide a link to the Creative Commons license and indicate if changes were made.

The images or other third party material in this chapter are included in the works Creative Commons license, unless indicated otherwise in the credit line; if such material is not included in the works Creative Commons license and the respective action is not permitted by statutory regulation, users will need to obtain permission from the license holder to duplicate, adapt or reproduce the material. 


\section{CHAPTER 9:}

\section{Individual Country Profiles}

These eight individual country profiles for each participating country are presented alphabetically. Each profile begins with a diagram illustrating the structure of the mainstream ECE system that is available to all children ${ }^{1}$ and a summary description of the ECE system in order to set the data presented into the context.

Below the age scale, each diagram contains a line indicating:

- the maximum possible length of childcare leave (accumulated length of maternity, paternity and parental leave);

- the age range that is defined as ISCED level 0; and

- the age range falling into the ISCED level 1 definition.

The diagrams also indicate the range of official ages at which children become eligible for admission to certain settings or types of ECE provision. The terms either relate to the ECE settings that are shown in the diagram or the type of provision if this was considered more appropriate, and are provided in the official language of the country. The diagrams visually summarize provision of center-based and/or home-based settings, with or without the involvement of the national Ministry of Education. When appropriate, different types of provision, cycles or key stages are indicated.

The diagram and the description of the ECE structure is then followed by a focused summary of each country's data as provided in the main report set out under five key sub-headings: Public policy; Delivery models and providers; Participation and enrollment; Supporting quality in ECE systems; and Expectations for child outcomes. More detailed data and information are provided in previous sections of the report.

1 Separate provision outside the mainstream ECE system for children with special educational needs is not included in the graphics. 
Country Profile: Chile

Structure

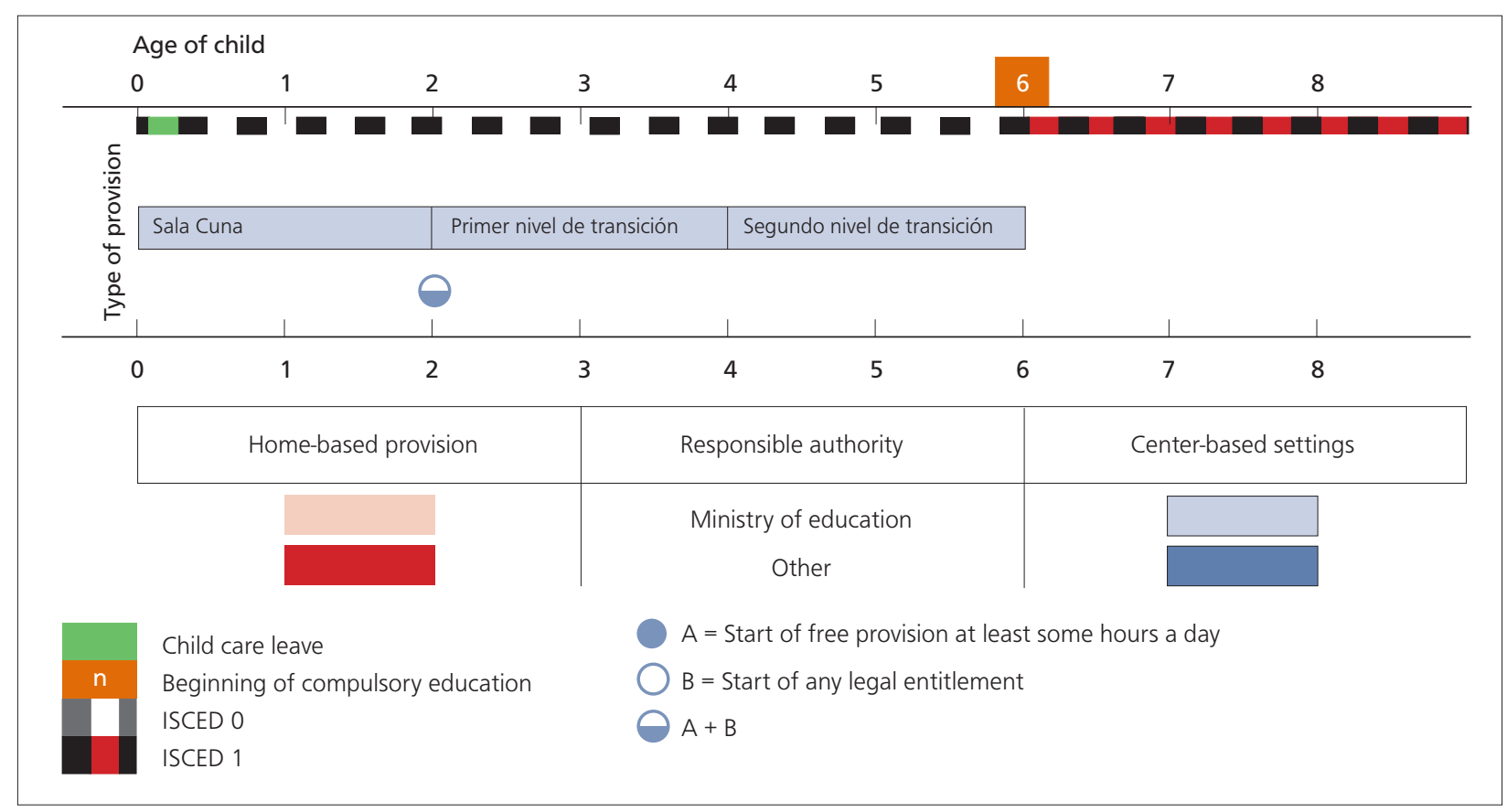

Source:

Based on European Commission/EACEA/Eurydice/Eurostat (2014), with permission. Data provided by the Chilean NRC.

ECE in Chile is a split system. The ECE level in Chile is considered by the General Law of Education (LGE) as the first level of the educational system. The LGE divides ECE into three levels, and, in turn, each level is subdivided into two-year cycles. First level: Nursery level (age 0-2), subdivided into junior nursery (age 0-1) and senior nursery (age 1-2). Second level: Middle level (age 2-4), subdivided into junior middle level (age 2-3 and senior middle level (age 3-4). Third level: Transition level (age 4-6), subdivided into first level of transition (or prekinder, age 4-5) and second level of transition (kinder, age 5-6). Children enter primary school at six years of age.

\section{Public Policy}

Chile has a wide range of policy aims for its ECE system which balance child care and early education priorities. These include providing child care to support parental employment and parental education and training, and providing early education to enhance children's socio-emotional skills; positive attitudes and dispositions; language and literacy competencies; basic mathematics skills; physical development; school preparation; and safeguarding. Governance and system management are centrally located, with responsibility for ECE being at national level, reflecting a single-level governance model. However, various national bodies are responsible for other strategic and operational aspects of the system, such as policy and legislation; quality; regulation, compliance and accountability; and funding and service delivery. For children from birth to three years (ECED), responsibility is divided among four departments: Education, Health, Work and Employment, and Social Welfare. For children aged three to six years (PPE), responsibility is split among three departments: Education, Health, and Social Welfare. Statutory entitlements for children and parents provide children 
with free, universal services from birth to six years of age, with the last year mandatory and a prerequisite to enter primary school at age six years. ECE is not considered compulsory, and there are no requirements for a child to enter ECE. In 2014, the second level of transition (for five to six year olds) became compulsory. For parents there is national statutory entitlement to parental leave; this is in the form of targeted paid maternity and targeted paid paternity leave. From 1999-2014 there have been policy changes across four key policy areas, including increased expenditure, enhanced statutory entitlements, improved staff:child ratios, and regulation and monitoring. Further policy changes are planned in relation to staff qualifications, ECE curriculum, quality assurance regulations, and child assessment.

\section{Delivery Models and Providers}

There is a diverse range of regulated, center-based provider types and settings offering services for under-threes, and three- to six-year-olds, including various types of kindergarten, integrated settings, and schools. These settings offer part and extended day services and offer long hours of opening. Settings can be public, private, community or charitable, and funded with public, private or a mixture of public and private subsidy. Funding mechanisms include supply-side funding through staff salary subsidy and capital grants, and demand-side funding through tax credits/relief.

\section{Participation and Enrollment}

Enrollment levels of children remain relatively low but increase with the age of the child; $19.2 \%$ of under-threes, and $77.3 \%$ of three- to five-year-olds are enrolled in services (2014). For under-threes, $12 \%$ of children enrolled come from low-income families and for three- to six-year-olds, $49 \%$ of enrolled children are from low-income families. These data suggest that, despite a targeting strategy, with national regulations for allocating prioritized places for children from low-income families, there may be economic and/or social barriers to families enrolling their children in ECE programs. Coverage of provision is universal for three- to six-year-olds, but for under-threes there is more limited coverage, particularly in rural areas. Strategies to enhance participation levels focus on extending geographical coverage, targeting low-income neighborhoods, and encouraging all-year-round services and full-day opening. There is a range of early intervention programs to support the participation of low-income families and minority ethnic groups, and children with special needs or disability. Chile has strategies and legislation to support cultural diversity in the delivery of early childhood services, including speech and language support programs.

\section{Supporting Quality in ECE}

Responsibility for the regulation of early childhood services is mainly at a national level, compliance bodies including the Superintendence of Educación, JUNJI (National Board), the Quality Agency and the Ministry of Education, the Ministry of Social Development, and the Controloría General de la República. At a subnational level, compliance bodies include the Municipality of each council, the Superintendence of Educación, the Controloría General de la República, the Ministry of Education, JUNJI and the Fundación Integra. Staff qualifications, training and remuneration vary with the type of setting and age of child served. There are two main categories of staff, namely teachers and teacher assistants, and one category of leadership, namely the director or principal. Teachers and leaders are usually required to have an ISCED Level 
5 qualification and teacher assistants must hold an ISCED Level 3 qualification. Group sizes are quite large and range from 32 children (aged between two and three years) to 45 children (aged five to six years). Staff:child ratios increase as the children as the children get older with more children per staff member. There are national health and safety regulations, which cover indoor space, indoor equipment, outdoor space, outdoor equipment, toilets, catering and nutrition. Chile has national curriculum guidance for ECE that encourages a broad and balanced learning program, including personal and emotional development; social development and citizenship; attitudes and dispositions to learning; physical development and health; language development and communication skills; reading and literacy skills; mathematical skills; understanding the world; science; and expressive arts, music and creativity. There is no specific guidance on a particular pedagogical approach for ECE. Parental participation in children's learning is supported by guidance on information transmission and consultation, and dialogue with parents. There is a national body responsible for the accreditation and inspection of ECE services that focuses on regulation compliance, staff performance, leadership and management, the curriculum program, and financial sustainability. The results of quality assurance are reported to the setting, the provider, and national bodies with responsibility, as well as being published on the internet for the wider public for use in strategic planning and service development.

\section{Expectations for Child Outcomes}

There are a broad range of expectations for child outcomes throughout the early childhood age phase, which includes personal and emotional development; social development and citizenship; attitudes and dispositions to learning; physical development and health; language development and communication skills; reading and literacy skills; mathematical skills; understanding the world; science; and expressive arts, music and creativity. Of these, six are formally assessed (personal and emotional development; social development and citizenship; physical development and health; language and communication; reading and literacy skills; mathematical skills) at the pre-primary level, and sometimes earlier, using a blend of assessment methods, including standardized tests and tasks. Outcomes data are reported to the national body responsible for ECE and used to inform strategic planning for policy and service development throughout the age phase. 


\section{Country Profile: Czech Republic}

\section{System Structure}

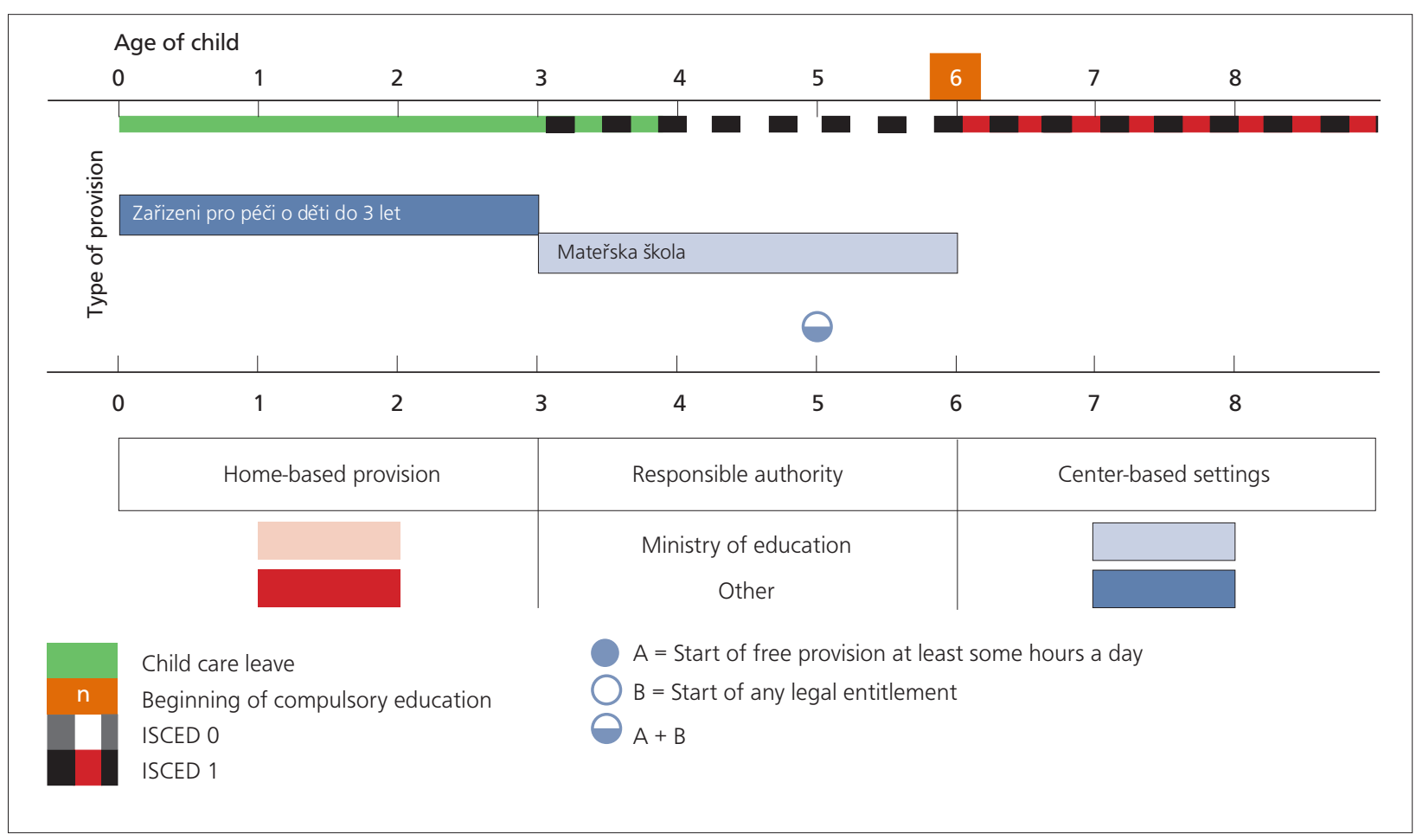

Source:

Adapted from European Commission/EACEA/Eurydice/Eurostat (2014), with permission.

ECE in the Czech Republic is a split system divided into two main structures: settings for children from birth to three years and settings for children aged from three to six years, after which they enter primary schooling. Center-based crèches or Jesle are the most common form of provision for under-threes, but the majority of children are cared for by their families or other informal care during this phase. For children from three to six years, public mateřská škola (kindergarten) is the predominant service, with a long history. From the age of five years, children are legally entitled to pre-primary education. Early childhood services are fee paying, with the exception of the final year of kindergarten, which is publicly-funded and provided free of charge.

\section{Public Policy}

The Czech Republic has a limited set of policy aims for its services for under-threes, which are mainly focused on supporting parental employment and supporting parental work/life balance. During the pre-primary phase, a wide range of policy aims are identified which balance child care and early education priorities. These include providing child care to support parental employment and parental work/life balance, and providing early education to enhance children's socio-emotional skills, attitudes and dispositions to learning, language and literacy skills, basic mathematical skills and physical development. Further policy aims include the preparation of children for school and for citizenship, to support children with special needs, to safeguard vulnerable children, to reduce inequality and social disadvantage, and to support children when home and national language are different. Governance and system management are 
centrally located, with one national body taking responsibility for services: for children under three years this is the Ministry of Work and Employment, and for pre-primary education this is the Ministry of Education. This reflects a single-level governance model. Statutory entitlements for children and parents provide children with free, universal services from three to six years of age but this is not considered compulsory. Parents have a statutory entitlement to parental leave in the form of paid maternity and paid paternity leave. Over the last five years there have been few policy changes but changes are currently planned for pre-primary education in relation to expenditure and the curriculum, and it has been debated by the government whether to make the final year of kindergarten compulsory.

\section{Delivery Models and Providers}

In the Czech Republic the range of provider types and settings are limited. For children under three years, crèches are the main center-based provision, and for three- to six-yearolds, public mateřská škola (kindergartens) are the predominant service. Kindergartens are organizationally divided into classes. It is possible to place children of the same or different ages in a class and create classes that are homogenous or heterogeneous in terms of age. In the same way, it is possible to place children with special educational needs into a common kindergarten class and thus create an integrated class. Kindergartens are mostly established as full-day operations (providing more than 6.5 hours child care per day, and at most 12 hours care per day). The largest founder of kindergartens is the municipalities, but a small number have been established by private founding entities and churches. Kindergartens are funded by public, private or a mixture of public and private subsidy. Funding mechanisms at pre-primary level include supply-side funding through staff salary subsidies, resource grants and capital grants, and demand-side funding through tax credits/relief and family allowances.

\section{Participation and Enrollment}

Child enrollment levels to ECE increase significantly with the age of the child, with only $4.0 \%$ of under-threes enrolled, climbing to $78.9 \%$ of three- to five-year-olds. During the pre-primary year (five- to six-year-olds) this again rises to $90.5 \%$ enrollment. There are no regulations for allocating prioritized places to children from low-income families, or strategies and legislation to support cultural diversity in the delivery of early childhood services. Coverage of ECE provision is universal for three- to six-year-olds, but for under-threes there is more limited coverage, particularly in rural areas and for children with special needs or disability. Currently, there are no reported national strategies to enhance participation levels for under-threes, but for pre-primary school age children there are a range of early intervention programs to support the participation of children from low-income families, children with special needs or disability, minority ethnic groups, and children where the home language differs from the national language.

\section{Supporting Quality in ECE}

Responsibility for the regulation of early childhood services is mainly at a national level with some aspects being regulated at commune level. Staff qualifications, training and remuneration for those working with under-threes are not documented, but at preprimary there are two main categories of staff, namely teachers and teacher assistants, and one category of leadership, the head teacher. Teacher assistants are required to have an ISCED Level 2 qualification, teachers an ISCED Level 5 qualification and 
head teachers an ISCED Level 6 qualification. Group sizes are between 24 and 28 children and staff:child ratios are 13 children to 1 adult throughout the pre-primary phase. There are national health and safety regulations, particularly for pre-primary settings, which cover such areas as staffing, indoor space, indoor equipment, outdoor space, outdoor equipment, toilets, catering and nutrition. The Czech Republic has no national curriculum guidance for settings working with under-threes, but a for pre-primary education, the national curriculum encourages a broad and balanced learning program, including personal and emotional development; social development and citizenship; attitudes and dispositions to learning; physical development and health; language development and communication skills; reading and literacy skills; mathematical skills; understanding the world; science; and expressive arts, music and creativity. There is no specific guidance on a particular pedagogical approach for ECE. Parental participation in children's learning is supported by guidance on information transmission, consultation and dialogue, and active participation of parents in children's learning. There is a national body responsible for the accreditation of all ECE settings, but only pre-primary settings receive inspection, which focuses on regulation compliance, staff performance, leadership and management, the curriculum program, children's learning outcomes, children's well-being, and financial sustainability. The results of quality assurance are reported on the internet for the wider public, and are used in the development of policy and practice in the following ways: performance management of ECE providers; commissioning providers; used by central, regional, local and provider bodies to inform strategy; used by settings to inform planning of services; used by ECE practitioner groups to inform the planning of services; and used by parental bodies to inform choice in ECE.

\section{Expectations for Child Outcomes}

There is a broad range of expectations for child outcomes for children in the pre-primary phase, but not for under-threes. These include personal and emotional development; social development and citizenship; attitudes and dispositions to learning; physical development and health; language development and communication skills; reading and literacy skills; mathematical skills; understanding the world; science; and expressive arts, music and creativity. There are no national assessments in the ECE phase. 


\section{Country Profile: Denmark}

\section{System Structure}

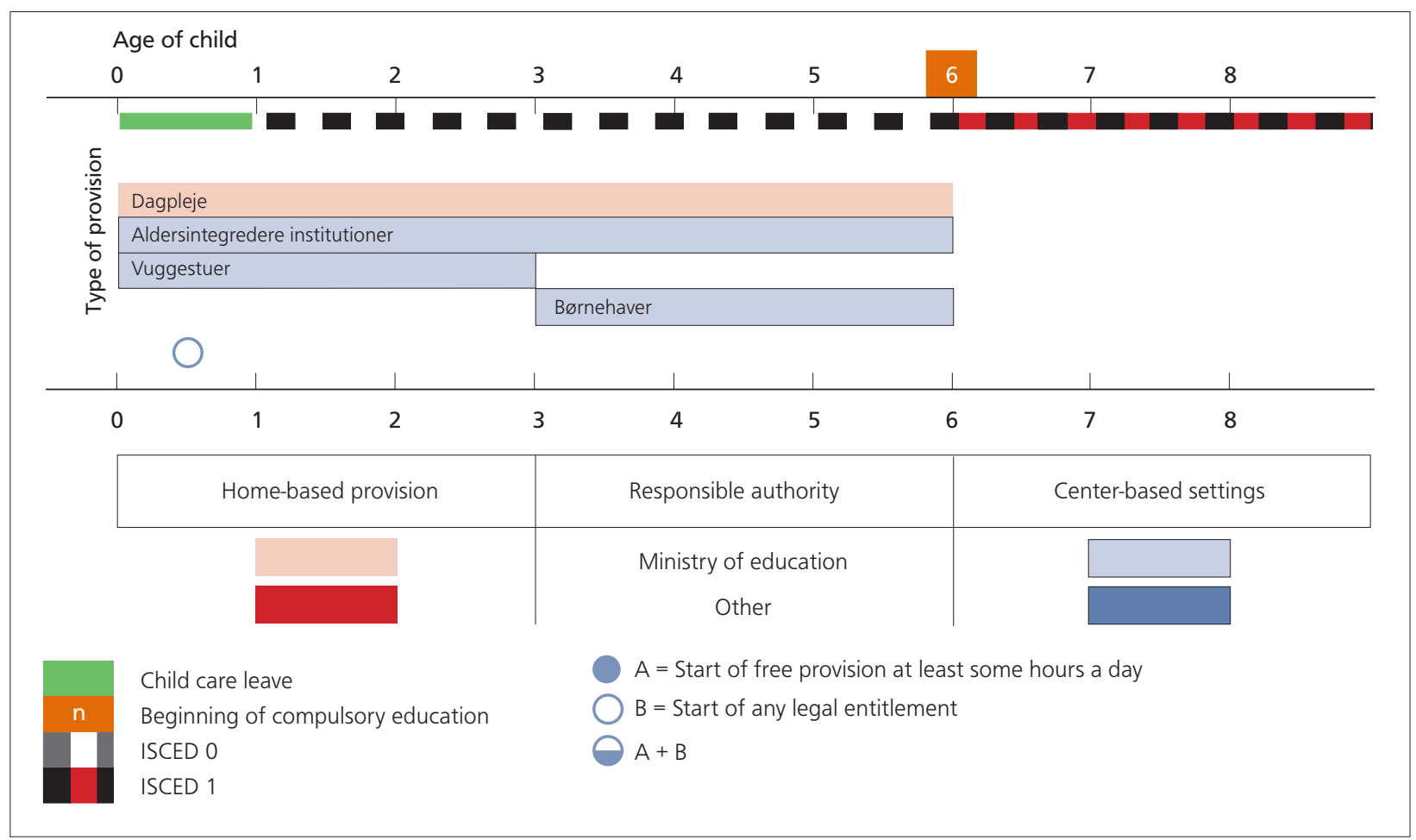

Source:

Adapted from European Commission/EACEA/Eurydice/Eurostat (2014), with permission. Additional information provided by the Danish NRC.

ECE in Denmark is both a split and unitary system with four different structures. Home-based care or Dagpleje is publicly funded, and provides part-time and extended day places to children from birth to three years of age. Nurseries or Vuggestuer are regulated, publicly-funded, center-based settings providing part-time and extended day places to children from birth to three years of age. Integrated Centers or Integreret daginstitution are publicly-funded centers that cater for children from birth to six years of age. They provide part-time and extended day places. Kindergartens or Børnehaver cater for children from three to six years of age. These settings are publicly funded and provide part-time and extended day places. Primary education starts at six years of age.

\section{Public Policy}

Denmark has a wide range of policy aims for its ECE services for children from birth to six years, which balance child care and early education priorities. These include providing child care to support parental employment, parent education and training, and parental work/life balance, and providing early education to enhance children's socio-emotional development, positive attitude and dispositions, language and literacy, basic mathematical skills, and physical development, preparedness for school, citizenship, special needs, safeguarding of vulnerable children; support for children where home language is different to the national language, and reductions in inequality. Further policy aims include the preparation of children for school and for citizenship, support for children with special needs, safeguards for vulnerable children, reductions in inequality and social disadvantage, and support for children whose home 
language differs from the national language. Governance and system management in Denmark are distributed between national and subnational levels, reflecting a multilevel governance model with one integrated department with responsibility for ECE. Statutory entitlements for children and parents provide children with free, universal services from birth to six years of age, but this is not compulsory. Parents have a statutory entitlement to parental leave in the form of paid maternity and paid paternity leave. Over the last five years, there have been policy changes in expenditure, staff qualifications and child assessments.

\section{Delivery Models and Providers}

In Denmark, there are four different provider types and settings. For children under three years, there is home-based and center-based provision, and for three- to six-yearolds there are nurseries and kindergartens. In addition, there are integrated centers that cater for children from birth to six years. All settings offer part and extended day services. All provision is publicly funded or subsidized. Funding mechanisms include supply-side funding through staff salary subsidies, resource grants and capital grants, and demand-side funding through reduced fees.

\section{Participation and Enrollment}

Child enrollment levels to ECE are high and increase with the age of the child; $65.7 \%$ of under-threes are enrolled and $94.1 \%$ of three- to five-year-olds. During the pre-primary year (five- to six-year-olds) enrollment rises further. There are no prioritized places for children, as there is universal entitlement and high levels of enrollment. Denmark has legislation and strategies to support cultural diversity in the delivery of early childhood services. Coverage of ECE provision is universal for children throughout the age phase and strategies exist to encourage the participation of children from low-income families. There is also a range of early intervention programs to support the participation of children from low-income families, children with special needs or disability, minority ethnic groups, and children whose home language differs from the national language.

\section{Supporting Quality in ECE}

Responsibility for the regulation of early childhood services is mainly at a national level with some aspects being regulated at local level. Staff qualifications, training and remuneration are regulated, with two main categories of staff, namely pedagogue and assistant pedagogue, and one category of setting leader. Assistant pedagogues are required to have an ISCED Level 2 qualification, and pedagogues and managers an ISCED Level 5 qualification. Staff remuneration is the same for both ECED and PPE, and the terminology used for the staff roles is also consistent between the two phases. Professional development is optional for all staff, including setting leaders. Group sizes are 10-14 for children aged birth to three years and 20-25 for children aged between three and six years, but this a recommendation rather than a regulation. Staff:child ratios are also not nationally regulated in Denmark, but government recommends that there are four to six children per educator at one to three years of age and eight children per educator at age three to six years. In reality, there are usually 11 children per adult for the age range three to six years and six children per adult for the age range birth to three years. There are health and safety regulations that cover such aspects as indoor space, outdoor space, toilet facilities, catering facilities, nutrition standards, suitability of staff, and risk assessments. Denmark has national curriculum guidance for ECE designed to 
encourage a broad and balanced learning program, including personal and emotional development; social development and citizenship; attitudes and dispositions to learning; physical development and health; language development and communication skills; reading and literacy skills; mathematical skills; understanding the world; science; and expressive arts, music and creativity. Parental participation in children's learning is supported by guidance on information transmission, consultation and dialogue. There is a national body responsible for inspection that focuses on regulation compliance; staff performance; leadership and management; children's learning outcomes; curriculum program; children's well-being; parental satisfaction; financial sustainability; and value for money. The results of quality assurance are reported to settings, parents, providers, and local and regional ECE bodies, and the findings are used to inform development of policy and practice.

\section{Expectations for Child Outcomes}

There is a broad range of expectations for child outcomes for children in ECE. These include personal and emotional development; social development and citizenship; attitudes and dispositions to learning; physical development and health; language development and communication skills; reading and literacy skills; mathematical skills; understanding the world; science; and expressive arts, music and creativity. There are no national or subnational assessments, and children's learning outcomes are not reported. 


\section{Country Profile: Estonia}

\section{System Structure}

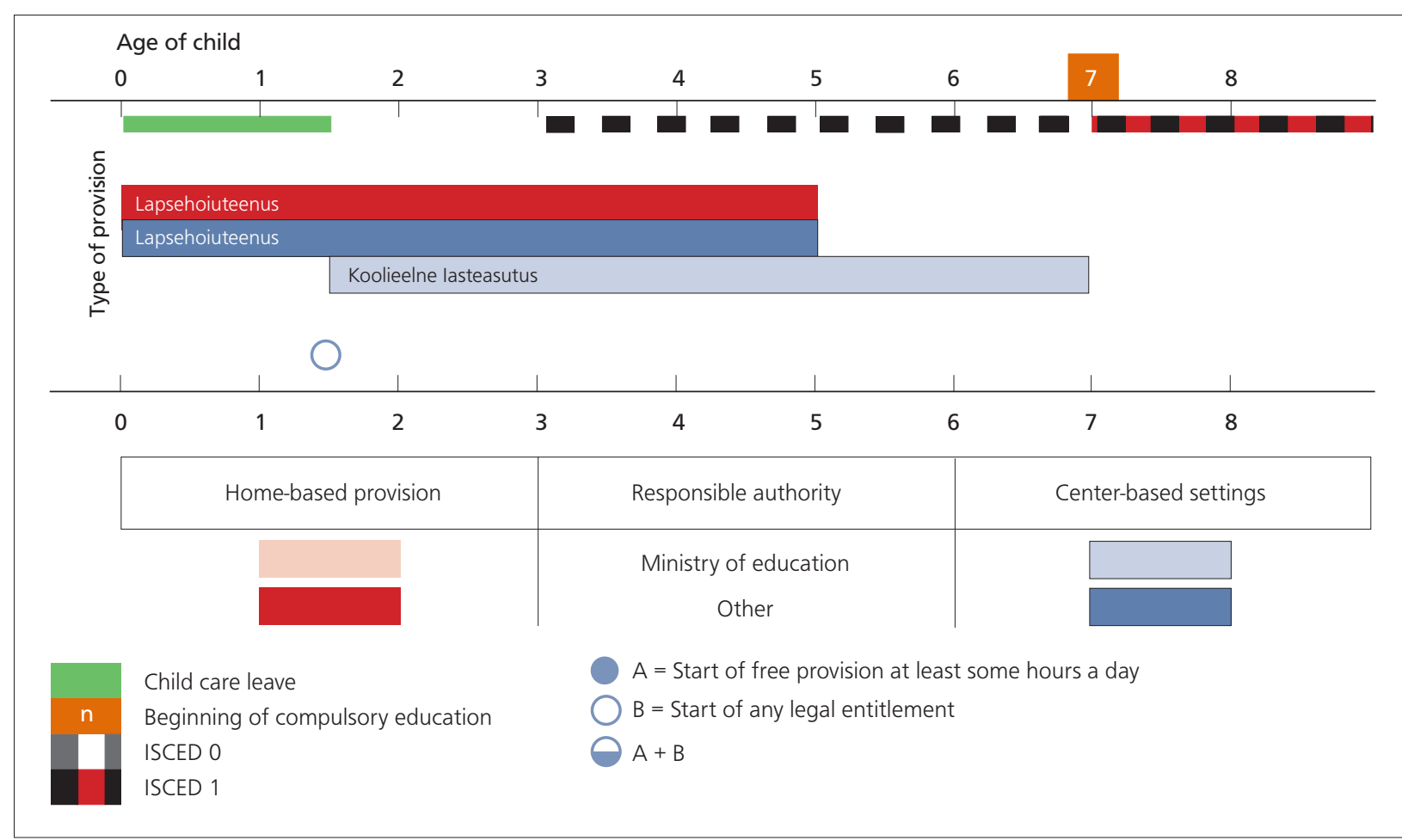

Source:

Adapted from European Commission/EACEA/Eurydice/Eurostat (2014), with permission.

ECE in Estonia is a unitary system. There are two main structures in the ECE system; child care centers called Lapsehoiuteenus and fully integrated educational institutions called Koolieelne lasteasutus for children aged from one and a half years to seven years offering day care and pre-primary education. Estonia has a unitary child care and education system under the responsibility of Ministry and Education and Research. Children start primary education at the age of seven years.

\section{Public Policy}

Estonia has a wide range of policy aims for its ECE services for children from birth to six years, which balance child care and early education priorities. These include providing child care to support parental employment, parent education and training and parental work/life balance, and providing early education to enhance children's socioemotional development; positive attitude and dispositions; language and literacy; basic mathematical skills; and physical development; preparedness for school; citizenship; special needs; safeguarding vulnerable children; supporting children where home language is different to the national language; and reducing inequality. Further policy aims include the preparation of children for school and for citizenship, supporting children with special needs, safeguarding vulnerable children, reducing inequality and social disadvantage and supporting children when home and national language differ. Governance and system management in Estonia are distributed between national and subnational levels, reflecting a multi-level governance model with responsibility for ECE shared between the Ministry of Education and the Ministry of Social Welfare. 
Statutory entitlements for children and parents provide children with free, universal services from eighteen months to seven years of age, but this is not compulsory. Parents have a statutory entitlement to parental leave in the form of paid maternity and paid paternity leave. Over the last five years there have been significant policy changes in curriculum, staff qualifications and child assessments, and further changes are planned in expenditure, staff:child ratios, quality inspection and monitoring, and teacher education and development.

\section{Delivery Models and Providers}

In Estonia there are two different provider types and settings delivering services to children from eighteen months to seven years, one having a child care orientation and the other a preschool orientation, though both types offer care and early education. Both of these setting types are publicly funded and funding mechanisms include supply-side funding through staff salary subsidy, place subsidy, resource grants and capital grants, and demand-side funding through reduced fees, tax credits/relief and family allowances.

\section{Participation and Enrollment}

Child enrollment levels to ECE are high and increase with the age of the child, with $23.6 \%$ of under-threes and $89.8 \%$ of three- to five-year-olds enrolled. During the preprimary years (five- to seven-year-olds) this rises to $100 \%$ of six- to seven-year-olds. There are no explicitly prioritized places for children as there is universal entitlement and high levels of enrollment, but there are guidelines that give preferential places to children whose elder siblings are already enrolled and to children whose home language differs from the national language. Estonia has legislation and strategies to support cultural diversity in the delivery of early childhood services. Coverage of ECE provision is universal for children throughout the age phase and strategies exist to encourage the participation of children from low-income families and to extend coverage in rural areas, and for ethnic minority children and children with special needs or disability. There is also a range of early intervention programs to support the participation of children from low-income families, children with special needs or disability, minority ethnic groups, and where the home language differs from the national language.

\section{Supporting Quality in ECE}

Responsibility for the regulation of early childhood services is mainly at a national level, with some aspects being regulated at local level. Staff qualifications, training and remuneration are regulated, with three main categories of staff, namely teacher, assistant and nurse, and two categories of setting leader, director and head teacher. Assistants are required to have an ISCED Level 3 qualification, nurses an ISCED Level 4 qualification, and teachers, directors and head teachers an ISCED Level 5 qualification. Staff remuneration is independent of the age of the children. Professional development is optional for teachers and assistants and required for directors and head teachers. Group sizes are 14-16 for children aged birth to three years and 20-24 for children aged between three and six years, and staff:child ratios are 7-8 children per educator for children from one to three years of age and 12 children per educator at age three to seven years. There are health and safety regulations that cover such aspects as indoor space, indoor equipment, outdoor space, outdoor equipment, toilet facilities, catering facilities, nutrition standards, medicine protocols, illness protocols, suitability 
of staff, and risk assessments. Estonia has national curriculum guidance for ECE that encourages a broad and balanced learning program, including personal and emotional development; social development and citizenship; attitudes and dispositions to learning; physical development and health; language development and communication skills; reading and literacy skills; mathematical skills; understanding the world; science; and expressive arts, music and creativity. In addition, from age three to seven years, children learn a second or foreign language. There is national or subnationally prescribed guidance on pedagogic approach for the entire age phase, which emphasizes creative, experiential, play-based pedagogies. Parental participation in children's learning is supported by guidance on information transmission, consultation and dialogue, and the active participation of parents in children's learning. There is a national body responsible for accreditation throughout the age phase, which focuses on regulation compliance, leadership and management, curriculum program, and financial sustainability. There is also a national system for inspection that evaluates staff performance; leadership and management; children's learning outcomes; curriculum program; children's well-being; parental satisfaction; financial sustainability; and value for money. The results of quality assurance are reported to all stakeholders (settings, providers, parents, local, regional and national bodies), and published in media and on the internet. The findings are used to inform all elements of developing policy and practice: accountability and performance management; commissioning providers; central, regional and local planning of ECE services; provider bodies strategic planning; settings strategic planning; ECE practitioner groups strategic planning; and used by parent groups to inform choice of ECE setting.

\section{Expectations for Child Outcomes}

There are a broad range of expectations for child outcomes for children in ECE. These include personal and emotional development; social development and citizenship; attitudes and dispositions to learning; physical development and health; language development and communication skills; reading and literacy skills; mathematical skills; understanding the world; science; and expressive arts, music and creativity. Children's learning outcomes in these areas are assessed, but the assessment methods differ between the under- and over-threes. For under-threes, assessments are only conducted using practitioner observations, whereas for pre-primary children there is a mixture of methods, including standardized tests and standardized tasks, as well as observations. The child outcomes data are collected and reported to both settings and parents. Outcome data are not reported to local, regional or national bodies or published in local media or on the internet. The outcome data are used to inform the development of ECE policy and practice, and used by settings and by practitioner groups to inform the planning of ECE programs. 
Country Profile: Italy

System Structure

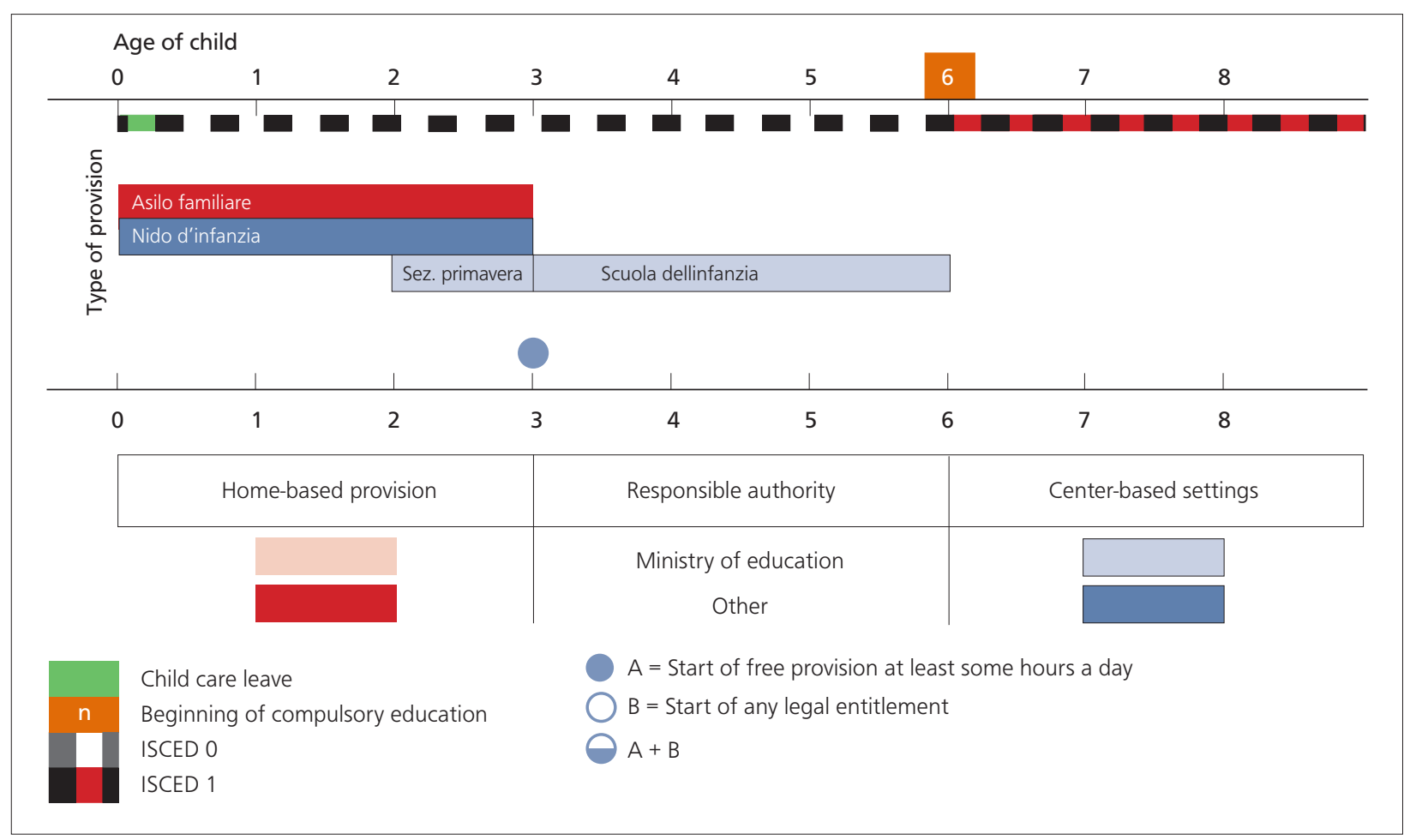

Source:

Adapted from European Commission/EACEA/Eurydice/Eurostat (2014), with permission. Additional information provided by the Italian NRC.

ECE in Italy is currently a split system. The recent reform of the education system with the passing of Italian Law 107 of July 2015 requires new legislation for the reunification of the split system in order to establish an integrated or unitary ISCED Level 0 system catering for children from birth to six years under the responsibility of the Ministry of Education. How this is going to be achieved cannot be reported here, due to the transitional period until such further legislation is issued. The country profile is thus based on the extant situation of the split system, supplemented by information on the expected changes whenever applicable.

Center-based provision for children aged birth to three years is in asili nido (nurseries, formerly nido d'infanzia) and other types of "integrative" services (including some home-based regulated care). These services are under the responsibility of the Ministry of Labor and Social Policy. ECE is not mandatory, but locally organized and subsidized: all municipalities and 21 regions and autonomous provinces have regulating competence over this matter. The Department of Family within the Presidency of the Council of Ministers also funds some birth to age three policies. Parents generally need to contribute to the costs of ECED provision, though in many regions costs tend to be low due to subsidies for lower-income families. Center-based provision for children aged three to six years is in scuole dell'infanzia (preschools), which is the first step of the state education system; this is not mandatory for children, and is free of charge (except for meals and transportation), enabling almost universal access. State preschools are generally hosted within comprehensive institutes with a curriculum for children aged 
three to fourteen years. Municipal pre-primary schools are also widespread and, in some areas (Rome for example), these may be linked to asili nido in the same area to offer integrated services for children aged birth to six years. State and municipal preschools generally offer also two additional options for children aged two to three years: the so-called anticipi (anticipation of enrollment to a pre-primary school) for children of two-and-a-half to three years old) and the sezioni primavera (literally spring sections) for children aged two to three years. These are two ways for children to start preschool earlier than three years of age. These services also function as a connection between the ECED and the PPE system. Anticipated enrollment and spring sections are particularly widespread in Southern Italy and generally located in deprived areas, since this provision is free in state preschools or considerably cheaper for parents in nonstate preschools compared with asili nido. Private provision, some of which subsidized in schools with "state status" equivalence, is available for both age ranges. Children enter primary education at six years of age.

\section{Public Policy}

Italy has a limited set of policy aims for its services for under-threes, which are mainly focused on supporting parental employment, supporting parental work/life balance, and remediating special needs (e.g. language delay). This is expected to change with the new reform, anticipating the introduction of an additional educational component into ECE for under-threes. During the pre-primary phase, a wide range of policy aims is identified, designed to balance child care and early education priorities. These include providing child care to support parental employment and parental work/life balance, and providing early education to enhance children's socio-emotional skills, attitudes and dispositions to learning, language and literacy skills, basic mathematical skills, and physical development, while introducing young children to citizenship, and reducing inequality and social disadvantage. Further policy aims include the preparation of children for the school transition, support for children with special needs, safeguarding vulnerable children, reducing inequality and social disadvantage, and support for children whose home language differs from the national language. Providing support for parental employment, parental education and training, and parental work/life balance are not stated aims for PPE in Italy. Governance and system management in Italy are distributed between national and subnational levels, reflecting a multi-level governance model with responsibility for ECE at a national level shared between the Ministry of Education (PPE, plus anticipated enrolments in PPE and Spring Sections) and the Ministry of Labor and Social Policies/Welfare and other cross-departmental bodies. The Ministry of Health cuts across ECED and PPE, with responsibility on periodic control of hygiene in preschools and nurseries; diagnosis and certification of disability for all children; control of diets for children in nidi; and pediatric visits in nidi. The Ministry of Finance has responsibility for the allocation of funds for early childhood according to a financial law passed in 2015. The July 2015 education system reform (Law 107) anticipates new legislation affecting governance: the Ministry of Education is expected to be responsible for the forthcoming integrated 0-6 system, with a new definition of functions and competencies at the regional and local level. It is important to notice that $0-3$ services will be excluded from the set of services at individual demand. In Italy there are no statutory entitlements for children to education and care services, yet PPE is free for children to attend. Employed parents do have statutory entitlement to paid and unpaid maternity and paternity leave, and an optional parental leave system (for 
a maximum of 10 months) which can be carried forward until a child's third birthday. From 2009-2014 there have been policy changes in expenditure (ECED and PPE), staff:child ratios, staff qualifications, curriculum, and inspection and monitoring (PPE only). Further changes are planned involving structural changes to reunify the birthto-six age group to form an integrated or unitary model of service delivery (according to the recently passed Law 107, July 2015).

\section{Delivery Models and Providers}

In Italy there are three main provider types and settings. For children under three years, there are child care nurseries or Nidi d'infanzia and integrative services or Servizi integrativi that include various types of provision, such as play spaces, child and parent groups, and home services. For three- to six-year-olds there are infant schools (preschools) or Scuola dell'infanzia offering early education. All settings offer part- and full-day services. Some settings are solely publicly funded, some solely privately funded and some receive a mix of public and private funding. Funding mechanisms include supply-side funding through resource grants and capital grants, and demand-side funding through tax credits/relief, vouchers and reduced fees (in ECED only).

\section{Participation and Enrollment}

Child enrollment levels to ECE in Italy increase with the age of the child, with 24.2\% of under-threes and $95.7 \%$ of three- to five-year-olds enrolled. There are no explicitly prioritized places for children as there is universal entitlement and high levels of enrollment in the PPE sector. Italy has legislation and strategies to support cultural diversity in the delivery of early childhood services. Despite an intention to provide universal access to services, coverage of ECE provision can be poor for some children, particularly for children under the age of three, and strategies exist to encourage the participation of children from low-income families and to extend coverage where shortages exist. The new July 2015 reform aims to increase low access rates for birth to two-year-olds with the future introduction of the unitary system. There are no reported early intervention programs to support less advantaged children. However, PPE support teachers exist for children with special needs and disabilities, in line with the inclusive nature of Italian preschool.

\section{Supporting Quality in ECE}

Responsibility for the regulation of early childhood services is at a national and subnational level, with some aspects being regulated at local level. Staff qualifications, training and remuneration are complex, and ECED and PPE staffing differs, staff groupings including nursery school educators, infancy school teachers, teacher aides, pediatric nurses, and four categories of setting leader. At the ECED level, senior staff are likely to be less qualified than their counterparts in PPE settings (Level 3 or upper secondary school level as compared with Level 5 or first stage tertiary level). Teacher aides or assistants in ECED and PPE settings do not need formal qualifications. There is also differentiation between the private and public preschool sector: in state preschools, teachers require an ISCED level 5 degree. Those in leadership positions are usually expected to have a level 5 or first stage tertiary level qualification, yet this is not always the case in the private sector. Teachers and head teachers in schools receive mandatory professional development (CPD) during their first year of service. The new July 2015 reform introduced mandatory training for all teaching staff, including 
preschool teachers in state schools. CPD is optional for all other staff and leaders. The qualifications, remuneration and training of staff and leaders are expected to change both for the new national contracts under discussion and for the new 2015 education system reform, subject to legislation anticipated as part of the 0-6 system reunification. Group sizes for settings for under-threes are determined by the size of the setting rather than the group size, and the teacher:child ratio is determined by typology of setting and teacher contract. For pre-primary state settings, classrooms have a minimum of 18 and a maximum of 26 children, with locally determined staff:child ratios in municipal PPE. Again, group sizes and staff:child ratios are expected to be altered, especially in the birth to two years segment, after the system reform. There are health and safety regulations that cover such aspects as indoor space, indoor equipment, outdoor space, outdoor equipment, toilet facilities, catering facilities, nutrition standards, medicine protocols, illness protocols, suitability of staff, and risk assessments. Italy has national curriculum guidance for pre-primary education (but not for ECED), which encourages a broad and balanced learning program, including personal and emotional development; social development and citizenship; attitudes and dispositions to learning; physical development and health; language development and communication skills; reading and literacy skills; mathematical skills; understanding the world; science; and expressive arts, music and creativity. A person-centered humanistic pedagogic approach is explicitly included in the 2012 curriculum guidelines for PPE, however this is balanced by the constitution, which recognizes school and teacher autonomy. Parental participation in children's learning is supported by guidance on consultation and dialogue, and active participation of parents in children's learning. There are national bodies responsible for accreditation and inspection for pre-primary settings, and subnational/local accreditation and inspection for settings serving children aged under three. Accreditation focuses on regulation compliance and curriculum program (PPE only). There is also a national system for inspection for PPE within the broader education system. The results of quality assurance are generally not reported to all stakeholders (just settings and providers).

\section{Expectations for Child Outcomes}

There are a broad range of expectations for child outcomes for children in pre-primary education, but none stated for under-threes. These generally match the areas of learning and development set out in the national curriculum guidelines for PPE. In Italy there are no national or subnational assessments or reporting of children's learning outcomes. 


\section{Country Profile: Poland}

\section{System Structure}

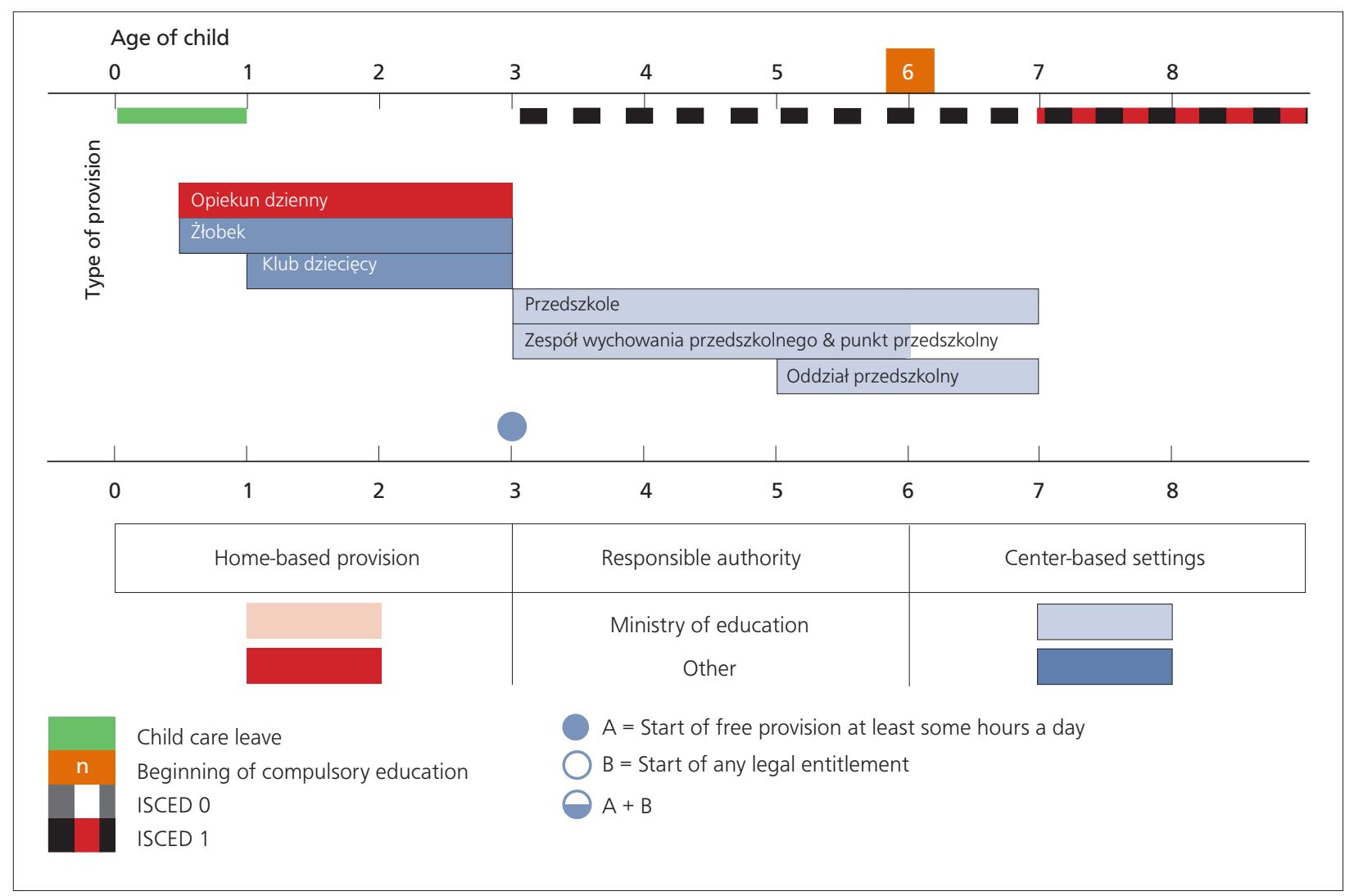

Source:

Adapted from European Commission/EACEA/Eurydice/Eurostat (2014), with permission. Additional information supplied by the Polish NRC.

ECE in Poland is a split system. For children under the age of three there is home-based day care or nannies. Center-based care is usually in crèches or, more recently, in kids clubs. Care up to age three is the responsibility of Ministry of Work and Social Policy. From age three to six years, the child is eligible for an optional preschool education. As from the school year 2004/2005, all six-year-old children attend a nursery school (przedszkole) or preschool classes (oddzialy przedszkolne) in primary schools, as the School Education Act introduced a one-year obligatory preschool preparation.

\section{Public Policy}

Poland has no stated policy aims for its services for under-threes, but during the preprimary phase, a wide range of policy aims are identified, which balance child care and early education priorities. These include early education to enhance children's socioemotional skills, attitudes and dispositions to learning, language and literacy skills, basic mathematical skills, and physical development. Further policy aims include the preparation of children for school and for citizenship, to support children with special needs and to safeguard vulnerable children. Governance and system management for ECE in Poland are located mainly at national level, reflecting a single-level governance 
model, with responsibility for under-threes being located with the Ministry of Health and an integrating body, and over-threes with the Ministry of Education. In Poland there are no statutory entitlements for children to education and care services under the age of three, but from three to six years universal part-time entitlement exists. Parents have statutory entitlement to paid and unpaid maternity and paternity leave. Over the last five years there have been policy changes in expenditure, staff:child ratios, staff qualifications and inspection and monitoring, and currently there are no further policy changes planned.

\section{Delivery Models and Providers}

In Poland there are three main provider types and settings. For children under three years, there is home-based care and center-based care, which can take two forms: crèche or kids clubs. The commune establishes crèches and kids clubs as public sector units at the commune level, or they can delegate the responsibility for their administration to other institutions, selected through an open competition. The default and most popular and oldest option are crèches. Kid clubs are smaller versions of crèches: they and offer less hours of day-care, they are a bit less restrictive and (also for this reason) they are also frequently run by individuals (and not by communes themselves). For children from three to six years old there are kindergartens or Przedszkole, preschool classes in primary schools or Oddział przedszkolny w szkole podstawowej and preschool units or Inne formy wychowania przedszkolnego: punkty przedszkolne i zespoly wychowania przedszkolnego, all of which offer pre-primary educational programs. Most settings offer part-time, full or extended day services. Some settings are solely publicly funded and some receive a mix of public and private funding. Funding mechanisms include supply-side funding through staff salary subsidy and capital grants, and demand-side funding through reduced fees.

\section{Participation and Enrollment}

Child enrollment levels to ECE in Poland increase with the age of the child, with 6.9\% of under-threes and $59.7 \%$ of three- to five-year-olds enrolled. At five to six years the enrollment rate is $94.0 \%$.There are no explicitly prioritized places for children as there is universal entitlement. Poland does not employ strategies to support cultural diversity in the delivery of early childhood services for under-threes, but there is legislation to ensure cultural diversity is respected in programs during pre-primary education. Coverage of ECE provision can be poor for children under the age of three, and strategies exist to encourage the participation of children under the age of three by extending coverage in rural areas where shortages exist. There are no reported early intervention programs to support less advantaged children.

\section{Supporting Quality in ECE}

Responsibility for the regulation of early childhood services is at a national and subnational level with many aspects being regulated at local level. Staff qualifications, training and remuneration are complex and the profile and professional training of staff are very different in settings that serve children under three years (ECED) compared to settings that serve children from three to six years old (PPE). For example, there is a much wider range of staff working with the younger children, including child carers, teachers, nurses, childbirth assistants, doctors and voluntary workers. Senior staff have a minimum ISCED Level 5 or first stage tertiary level qualification and assistant staff 
have a minimum ISCED Level 3 or upper secondary school level qualification. Health oriented staff can be qualified at ISCED Level 4 or 5 and are required to undertake CPD. The settings leaders (principals) have to have higher qualifications if they work in PPE settings, and they earn significantly more. Group sizes and staff:child ratios are not regulated. There are health and safety regulations that cover such aspects as indoor space; indoor equipment; toilet facilities; catering facilities; medicine protocols; suitability of staff; and fire safety. Poland has no national curriculum guidance for settings serving under-threes (ECED) but for pre-primary education the national curriculum guidance encourages a broad and balanced learning program, including personal and emotional development; social development and citizenship; attitudes and disposition to learning; physical and health education; language and communication; reading and literacy; mathematical skills; understanding the natural world; science; technology and the digital world; and second/foreign language. Poland prescribes two pedagogic approaches: an academic formal approach and an experiential approach. Parental participation in children's learning is supported by national guidance on information transmission and active participation of parents in children's learning. There are subnational bodies responsible for accreditation and inspection for all ECE settings. Accreditation focuses on regulation compliance and curriculum program (PPE only). Inspection of pre-primary education focuses on staff performance; leadership and management; children's learning outcomes; curriculum program; children's wellbeing; parental satisfaction; and financial sustainability. The results of quality assurance are reported to the settings and the local bodies with responsibility for the setting. For pre-primary settings, results are also published on the internet and the NRCs report that the findings are used to inform the development of policy and practice at national, local and setting level.

\section{Expectations for Child Outcomes}

There are no child outcome expectations for children under the age of three years in Poland. For children aged from three to six years there are a broad range of expectations for child outcomes for children in ECE. These include personal and emotional development; social development and citizenship; attitudes and dispositions to learning; physical development and health; language development and communication skills; reading and literacy skills; mathematical skills; understanding the world; science; and expressive arts, music and creativity. Children's learning outcomes in these areas are assessed and the assessment methods include standardized tests and standardized tasks, as well as teacher observations. This child outcomes data are collected and reported to settings, parents, providers, local, regional and national bodies responsible for ECE, and results are published on the internet. The outcome data are used by government to inform and develop policy and practice nationally through accountability and performance management of settings, and by central, regional and local bodies to inform strategic planning. 
Country Profile: Russian Federation

System Structure

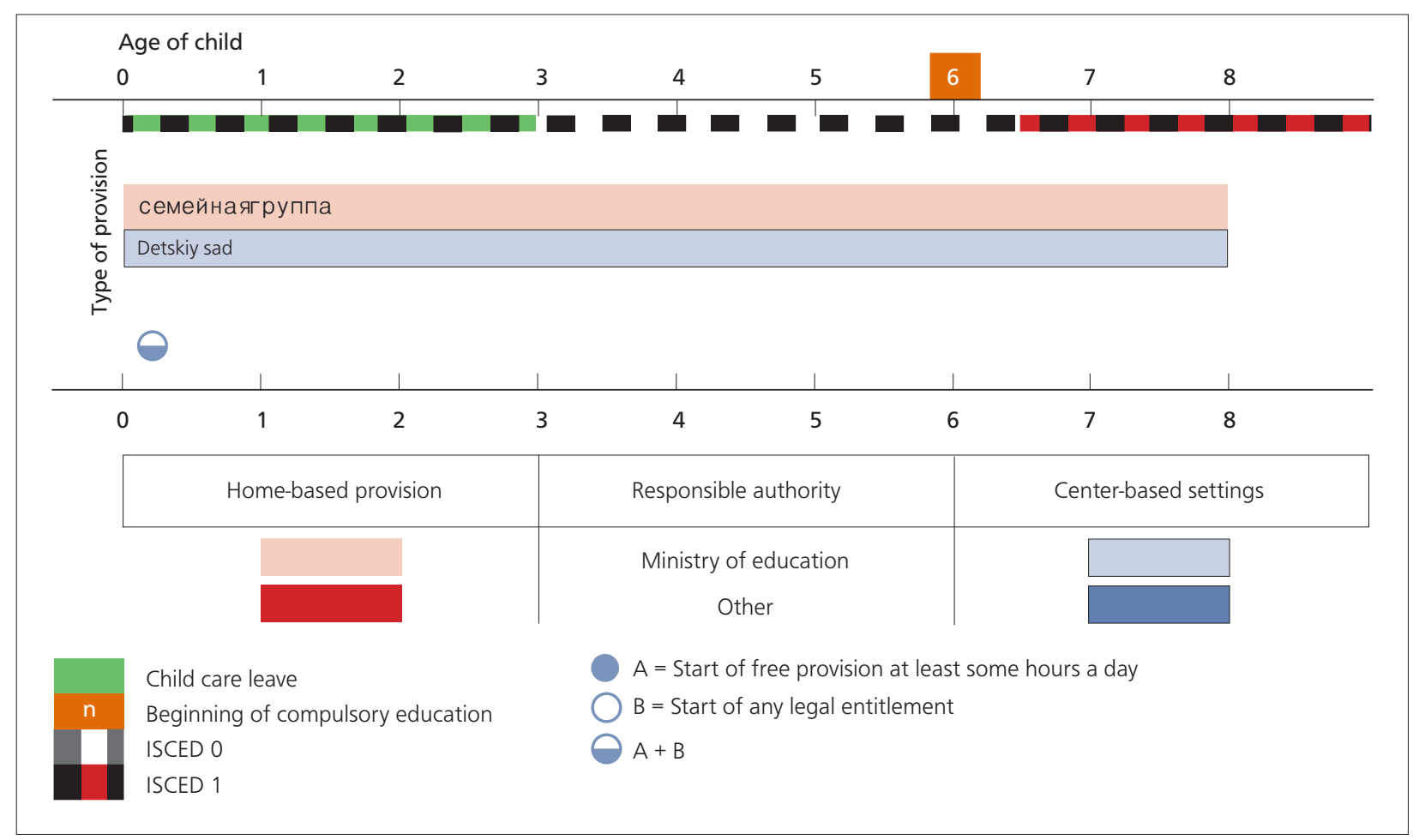

Source:

Based on European Commission/EACEA/Eurydice/Eurostat (2014), with permission. Data provided by the Russian Federation NRC.

ISCED level 0 is regulated by federal state law published by the Ministry of Education and Science of the Russian Federation in 2012. Preschool education (ISCED Level 0) is one of the stages of general education. Citizens in the Russian Federation have the right to preschool education and the state guarantees this right. Preschool education is public, free of charge and non-compulsory, and it has two forms: home-based and center-based. Home-based education is mostly presented by family groups; this can be organized by preschool settings on a home basis or it can be a private home-based group. Center-based preschool education can be taken starting from two months of age, but programs for children from two months to eighteen month are very rare and not presented as part of the public preschool educational service. Women have three years child care leave, with the first one-and-a-half years paid; the last one-and-a-half years are non-paid. Therefore public education and child care is only needed when a child is about one-and-a-half years old. Public educational programs for one- to three-yearolds were highly represented in the system, but in the last two years they have decreased. All the public preschool educational resources are focused on providing full-time, center-based, preschool education for three- to seven-year-old children, increasing its availability and coverage. Primary school can be started between six-and-a-half and eight years of age. A new federal law on education has introduced the new possibility of organizing groups of care and supervision of children from two months to seven years in a preschool setting without the implementation of an educational program of preschool education. This service is not subventioned by the Federal Ministry of 
Education. Preschool education can be provided by either public or private settings as long as they have a license.

\section{Public Policy}

The Russian Federation has a wide range of policy aims for its ECE services, which balance child care and early education priorities. These include providing child care to support parental employment and parental work/life balance, and providing early education to enhance children's socio-emotional skills, attitudes and dispositions to learning, language and literacy skills, basic mathematical skills, and physical development. Further policy aims include the preparation of children for school and for citizenship, to support children with special needs, to safeguard vulnerable children, to reduce inequality and social disadvantage and to support children when home and national language are different. Governance and system management in the Russian Federation are distributed between national and subnational levels, reflecting a multilevel governance model with responsibility for ECE at a national level shared between the Ministries of Education, Health and Work and Employment and other cross-cutting departmental bodies. There are statutory entitlements for children to free, public education and care services. Parents have statutory entitlement to paid and unpaid maternity and paternity leave. Over the last five years there have been policy changes in staff:child ratios; national curriculum; regulation, inspection and monitoring; child assessment and teachers' salaries; and the financing model. There are no further changes currently planned.

\section{Delivery Models and Providers}

In the Russian Federation there are two basic delivery models and provider types and settings: home-based child care and center-based kindergartens of various types. Most settings offer part, full or extended day services (including overnight in some settings). Some settings are solely publicly funded and some receive a mix of public and private funding. Funding mechanisms include supply-side funding through staff salary subsidy and capital and resource grants, and demand-side funding through reduced fees.

\section{Participation and Enrollment}

Child enrollment levels to ECE in the Russian Federation increase with the age of the child, with $84 \%$ of three- to five-year-olds enrolled. There are prioritized places for children from low-income families. Strategies and legislation exist to support cultural diversity in the delivery of early childhood services. Coverage of ECE provision is universal, but access can be difficult in some rural areas and for children with special needs or disability. Strategies exist to encourage the participation of children by extending coverage in rural areas where there are shortages. There are early intervention programs to support low-income families; children with special needs/disability; minority ethnic groups; and children whose home language differs from the national language.

\section{Supporting Quality in ECE}

Responsibility for the regulation of early childhood services is at a national and subnational level, with many aspects being regulated at local level. Staff qualifications, training and remuneration are complex as a wide range of professionals from the health, care and education are represented in the workforce, and tend to be highly qualified. These staff include educators, educator assistants, junior educators, methodists, speech therapist teachers, psychologists, music teachers, physical development teachers, and 
three categories of leader. Senior staff have a minimum ISCED Level 6 qualification and assistant staff have a minimum Level 3 qualification. Health oriented staff are qualified at Level 4 to 6 and must undertake CPD, which is optional for other staff categories. Group sizes and staff:child ratios are regulated by the size of setting and its floor space rather than the size or age of the group. There are health and safety regulations that cover such aspects as indoor space; indoor equipment; toilet facilities; catering facilities; medicine protocols; suitability of staff; and fire safety. In addition, regulations cover natural and artificial rooms lighting; requirements for heating and ventilation; requirements for water and sanitation; requirements for admission of children in preschool organizations, the regime of the day and the organization of education process; requirements for the organization of physical education; requirements for sanitary maintenance of preschool rooms; requirements to undergo preventive medical examinations, hygiene education and training, personal hygiene of staff; and requirements for sanitary. The Russian Federation has national curriculum guidance for settings serving under-threes (ECED) and children aged three to six (PPE) that encourages a broad and balanced learning program, including personal and emotional development; social development and citizenship; attitudes and disposition to learning; physical and health education; language and communication; reading and literacy; mathematical skills; understanding the natural world; science; technology and the digital world; and second/foreign language. There is also national or subnationally prescribed guidance on pedagogic approaches, which is the same for both ECED and PPE. These are creative/progressive, experiential, and a play curriculum, as well as a child centered approach based on Vygotsky's cultural-historical theory. Parental participation in children's learning is supported by guidance on information transmission and the active participation of parents in children's learning. There are no accreditation processes, but there are subnational bodies responsible for inspection for all ECE settings. Inspection focuses on regulation compliance, financial sustainability, and value for money. The results of quality assurance are reported to the settings and the regional bodies with responsibility for the setting, and they are also published on the internet. The NRC reports that findings are used to inform the development of policy and practice at national, local and setting level.

\section{Expectations for Child Outcomes}

There are a broad range of expectations for child outcomes for children under three, which include personal and emotional development, physical development and health, and language and communication. For three- to six-year-olds, the expectations for learning include personal and emotional development, social development and citizenship, attitudes and dispositions to learning, physical development and health, language and communication, and understanding the natural world. In the Russian Federation there are no national or subnational assessments or reporting of children's learning outcomes. 


\section{Country Profile: United States}

\section{System Structure}

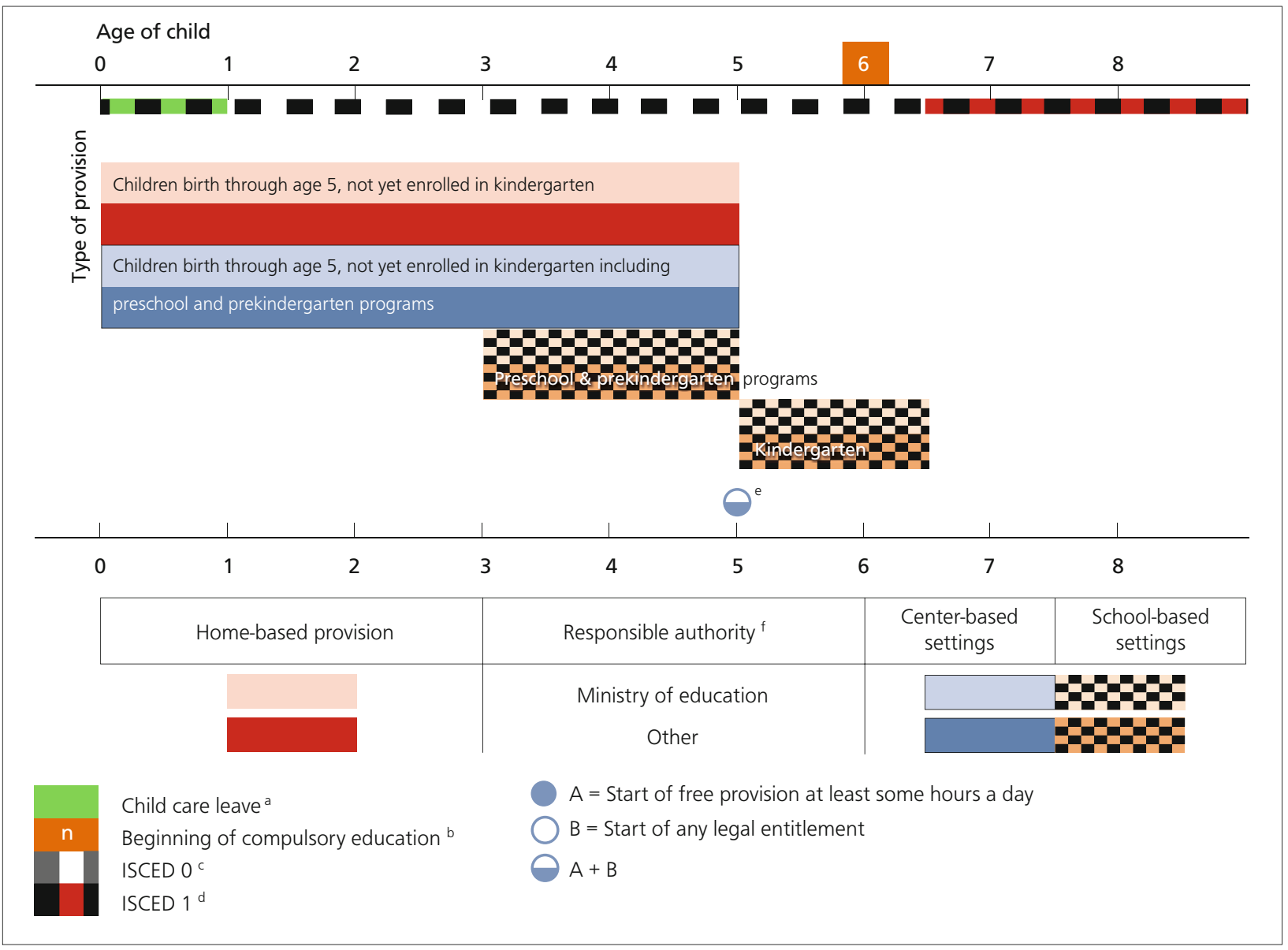

\section{Source:}

Based on European Commission/EACEA/Eurydice/Eurostat (2014), with permission. Data provided by the United States NRC.

\section{Explanatory notes:}

a Within the United States, parental leave falls under the Family and Medical Leave Act (FMLA), where parents are allowed 12 work weeks of unpaid, job-protected leave within the first 12 months from when a child is born, adopted or placed in foster care. Therefore parents with children above the age of 1 only qualify if the child was adopted or placed in their care in that 12 month period. This entitlement can also be used by parents if their child has a serious health condition. All eligible employees are allowed up to 12 workweeks of unpaid job-protected leave that can be used for when a child is ill with a serious health condition and needs to be cared for by the parent, regardless of the age of the child. Employees eligible for this entitlement usually must have worked for the specific company for at least 1 year before they quality.

${ }^{b}$ Within the United States, the beginning of compulsory education varies by state, from age 5 to age 8 . Age 6 is the most frequency occurring age, within 25 states. Age 7 is the next most frequently occurring age, within 13 states.

c Within the United States, children from birth through kindergarten are classified as ISCED 0. Within the United States, in the majority of states, kindergarten begins the last week of August or the first week of September and to enroll children must be five years of age by the start of kindergarten (this varies by state).

d Within the United States, ISCED 1 begins with first grade.

e Within the United States at ages 5-6 (kindergarten) there is more or less a universal entitlement. 45 out of 50 states plus the District of Columbia require school districts to offer kindergarten. Of those, 34 require school districts to at least offer half day services, while 11 states plus DC require school districts to offer full-day kindergarten.

${ }^{f}$ Reflecting a multi-level governance model, in the United States responsibility for early childhood education (ECE) is largely at the state- and local-level with some federal-level support and involvement. Responsibilities for ECE at both the state- and the federal-level are shared between such agencies as the Department of Education and the Department of Health and Human Services. In the figure, any state- or federal-level involvement in ECE is coded as Ministry of Education. In the United States ECE is also privately provided. This is true of home-based, center-based, and school-based settings from birth through kindergarten. Private provision is coded as "other." Therefore in the figure, all settings for all age groupings are coded as both government and private. 
Early childhood education and care in the United States is largely decentralized. ISCED Level 0 within the United States includes children from birth through to their kindergarten year. Within the United States, the last year of ISCED 0 is children's kindergarten. ECE is described with different names, such as child care, day care, preschool and prekindergarten. It is delivered in different settings, from within a center, within a home, and within the local public or private school. Some programs are offered at little or no cost to parents, particularly for low-income parents. Other programs may cost a high proportion of a parent's income. The majority of ECE settings that serve children from birth through age of five (that is children not-yet-enrolled-inkindergarten) are private fee-based services. There are some notable state-funded or federally-funded programs as well, but currently the majority of these programs are not universally available to all age eligible children within the state. Below are examples of some of the programs and legislation in the United States that are designed to make ECE more accessible and affordable for all children:

- Head Start and Early Head Start: Head Start and Early Head Start are federallyfunded programs that promote the school readiness of young children from lowincome families through agencies in their local community. Head Start programs support the mental, social, and emotional development of eligible children aged three to five-but-not-yet-enrolled-in-kindergarten, while Early Head Start programs are available to eligible families from birth until the child turns three years old.

- Title I: Title I is a federal grant program designed to give educational assistance to students living in areas of high poverty. The Title I program originated in 1965, when Congress passed the Elementary and Secondary Education Act, and was reauthorized in 2001 with the passage of the No Child Left Behind Act. Over 600,000 children are served through preschool programs funded through federal Title I allocations to school districts and schools.

- The Individuals with Disabilities Education Act (IDEA): IDEA ensures that all children with disabilities are entitled to a free appropriate public education to meet their unique needs and prepare them for further education, employment, and independent living. IDEA provides guidelines concerning the funding and services to children from birth to two years of age, and from age three to age twenty-one. For example, IDEA states that every family is entitled to appropriate and timely identification and intervention services for children aged birth to two years. For eligible children aged three to twenty-one, every child is entitled to a free and appropriate public education.

- The Child Care and Development Block Grant (CCDBG): CCDBG helps lowincome families, families receiving public assistance, and those families transitioning from public assistance in obtaining early education and care.

- Two new programs began in 2015. The Preschool Development Grants program supports states to develop or enhance preschool programs and expand opportunities for high-quality preschool to children from low- to moderate-income families. The Early Head Start-Child Care Partnerships support local programs in improving the quality of child care.

- Currently, forty-four states and the District of Columbia have a state preschool program or are piloting one. During the 2013-2014 school year, 29\% of four-yearolds and $3 \%$ of three-year-olds were served in such programs; more than 1.3 million children attended state-funded preschool, including 1.1 million at age four (Barnett et al., 2015). 
Within the United States the final year of PPE for most children is kindergarten. In the United States, kindergarten is regulated by individual states. In 45 states and DC, school districts are required to provide kindergarten programs, 11 states plus DC require school districts to offer full-day kindergarten and, in 15 states and DC, kindergarten attendance is mandatory.

\section{Public Policy}

The United States has a wide range of policy aims for its ECE services, which balance child care and early education priorities. These include providing ECE to enhance children's socio-emotional skills, approaches to learning, language and literacy skills, cognitive skills such as early mathematics and science skills, and health and physical development. Further policy aims include the preparation of children for school, support for children with special needs, safeguarding vulnerable children, and reducing inequality and social disadvantage. Governance and system management in the United States are largely at the state and local level, with some federal responsibilities, reflecting a multi-level governance model. Responsibility for ECE at the federal level is shared between such federal agencies as the Department of Education, the Department of Health and Human Services, the Department of Defense, and the Bureau of Indian Affairs. There are no statutory entitlements for children to ECE, but in the majority of states, school districts are obliged to offer kindergarten programs. In the United States there is no statutory entitlement to parental leave and pay, but the FMLA provides certain employees with up to 12 weeks of unpaid, job-protected leave per year. Policy changes in ECE in a number of areas are planned between 2014-1019, reflecting changes underway in the system.

\section{Delivery Models and Providers}

In the United States, a wide range of settings comprise the ECE system. Settings vary in terms of location, from private homes to more formalized settings such as centers or within schools. They vary in terms of hours of operation, with some more than covering the work day and others providing half-day services. ECE within the United States is described using different names, such as child care, day care, preschool, prekindergarten, and transitional kindergarten. Services are funded through private and public subsidy. Funding mechanisms include supply-side funding through funded places, staff salary subsidy, and capital and resource grants, through programs such as Head Start, Child Development Block Grants, and the Individuals with Disabilities Education Act. Funding mechanisms also include demand-side funding through tax credits, vouchers and reduced fees.

\section{Participation and Enrollment}

Child enrollment levels to ECE in the United States increase with the age of the child, with approximately $43 \%$ of ECE aged children participating in ECE and $61 \%$ of PPE aged children participating in ECE. There are prioritized places in some programs such as Head Start, for children from low-income families, children with special needs or disability or from certain minority ethnic groups. Strategies and legislation exist to support cultural diversity in the delivery of early childhood services. Coverage of ECE provision is not universal, and access can be difficult for children from low-income families or with special needs or disability. There are early intervention programs to encourage the participation of children from low-income families; children with special needs/disability; minority ethnic groups; and children whose home language differs from the national language. 


\section{Supporting Quality in ECE}

Responsibility for the regulation of early childhood services is concentrated at the state level. Staff qualifications, training and remuneration are complex in the United States due to the decentralized nature of the system and the different types of home- and center-based provision. ECE staff includes lead teachers, teachers, assistant teachers and aides. For staff who work in ECED settings, qualification requirements vary. There are specific setting types within the broader category "center-based" that require certain levels of education. For example, Early Head Start/Head Start programs have education requirements for different levels of staff. However, there is no uniform requirement across all of the different kinds of center-based settings within the US center-based day care centers, preschools or prekindergarten programs. Group sizes and staff:child ratios are set at the state licensing level, but the majority of states with ECE initiatives set class size and ratio requirements that are consistent with standards developed jointly by the American Public Health Association (APHA) and the American Academy of Pediatrics (AAP) and the National Association for the Education of Young Children (NAEYC). Ratios and group sizes increase with the age of the child, with a group size of eight, and a staff:child ratio of one adult per four children for children under one year, a group size of 17-18 and a ratio of one adult per 10 children for three-year-olds, and finally a group size of 20, and a staff:child ratio of one adult per 10 children for five-year-olds. There are health and safety regulations that are set at state licensing level covering such matters as health and safety, child protection, and staff vetting procedures. The United States has no national curriculum; however, the United States does offer national guidance or recommendations on elements that should be covered in a curriculum for under-threes and children aged from three to five years. Individual states have Early Learning Standards which cover birth to five years. The guidance generally encourages a broad and balanced learning program, including personal and emotional development; social development and citizenship; attitudes and disposition to learning; physical and health education; language and communication; reading and literacy; mathematical skills; understanding the natural world; science; technology and the digital world; and second/foreign language. The guidance also identifies a range of pedagogic approaches that might be adopted, including an academic/ formal instruction approach; creative or progressive learning; an experiential approach; and a play curriculum approach. Parental participation in children's learning is supported by guidance on information transmission, consultation and dialogue, and the active participation of parents in children's learning. There are accreditation and inspection processes to support quality assurance. Accreditation is voluntary, and often accreditation guidelines exceed those of licensing guidelines. Examples of the range of accrediting bodies, include the National Association for the Education of Young Children, Head Start Renewal system, Montessori, Reggio Emilia Alliance, and the IB Primary Years Program. In the United States, each state has its own licensing inspection, whereas the federal government monitors and inspects federally-funded programs such as Head Start. The results of quality assurance are reported to the settings and more widely, and used to inform the development of policy and practice at federal, state and setting level. 


\section{Expectations for Child Outcomes}

There are a broad range of expectations for child outcomes in the United States for children from birth through to kindergarten, which include personal and emotional; social development and citizenship; attitudes and dispositions; physical and health; language and communication; reading and literacy; mathematics; understanding the natural world; science; and expressive arts, music and design. In the United States there are no typical national or typical subnational assessments or reporting of children's learning outcomes.

Open Access This chapter is distributed under the terms of the Creative Commons AttributionNonCommercial 4.0 International License (http://creativecommons.org/licenses/by-nc/4.0/), which permits any noncommercial use, duplication, adaptation, distribution and reproduction in any medium or format, as long as you give appropriate credit to the original author(s) and the source, provide a link to the Creative Commons license and indicate if changes were made.

The images or other third party material in this chapter are included in the works Creative Commons license, unless indicated otherwise in the credit line; if such material is not included in the works Creative Commons license and the respective action is not permitted by statutory regulation, users will need to obtain permission from the license holder to duplicate, adapt or reproduce the material. 


\section{CHAPTER 10:}

\section{Final Reflections: Emerging Policy Issues}

Recent cross-national studies (EIU, 2012; European Commission/EACEA/Eurydice/ Eurostat, 2014; OECD, 2012b; Pascal et al., 2012) have revealed that many countries have, or are developing, a funded, government-led, ECE policy with stated aims and intentions. Research indicates an emerging consensus that broad policy aims and strategies for ECE should be set by government policy to stimulate further development and improvement of ECE systems (EIU, 2012; European Commission/EACEA/ Eurydice/Eurostat, 2014; OECD, 2012b). Today, many governments see ECE as a public investment with huge returns, and are making considerable effort to support the development of ECE as an effective tool to help children build a strong foundation for school and life success and, therefore, better life chances, especially for children from disadvantaged and migrant backgrounds, and children with special needs or disabilities. However, despite shared policy intentions, these recent studies also reveal that countries are at very different stages of policy development and implementation, and may have adopted different strategies to achieve the shared goal of an affordable, accessible and effective ECE system.

As countries worldwide continue to work at ECE system development, and policy options continue to be debated, the need to document and evaluate alternative systems, policy choices and their consequences, has become more important. The ECES aims to contribute to this reflective and evaluative process, and provides detailed, crossnational information from eight countries with the intention of supporting the wider development of ECE policy and practice. The study provides contextual evidence on the structural and systemic characteristics of the ECE and care systems in each participating country, captures in-country and between-country variations in policy and systems, and documents key policy changes underway and planned. As Dr Hans Wagemaker, former IEA Executive Director, stated:

"Each country faces its own particular challenges toward achieving an equitable, high-quality early childhood education system. [...] ECES will enable countries to thoughtfully examine their own goals and policies in this critical area, and to learn from each other's best practices." (International Association for the Evaluation of Educational Achievement, 2013)

Documenting current ECE policy aims and strategies in a range of countries which exemplify different policy approaches can help to explain the orientation of ECE services and give a wider perspective to the development of ECE systems. This final chapter of the policy report sets out to provide a critical reflection on the key policy issues and questions that flow from the main findings in the eight study countries, highlighting how these policy findings support or differ from other recent crossnational policy studies. It is hoped that the key policy issues identified will provide an agenda for policymakers and providers to consider as they continue to move their ECE systems forward.

The policy analysis within and between the eight study countries has highlighted a number of questions and issues that may be of particular interest to ECE policymakers. These issues or questions are to be found in each of the five aspects of policy implementation addressed in the data discussed in previous chapters, and are set out below. 


\section{Public Policy}

Cross-national studies (EIU, 2012; European Commission/EACEA/Eurydice/Eurostat, 2014; OECD, 2012b; Pascal et al., 2012) have consistently argued that public policy should support the development of an ECE system that ensures access and entitlement to a high quality service for all children from birth to the start of primary schooling. To ensure a certain length of participation in ECE programs, countries often provide legal entitlements to ensure access to affordable, high-quality ECE. The OECD (2012a) study found that many countries have started to offer "free" ECE services (i.e., free at the point of delivery) to certain age groups, usually one or two years before the start of compulsory schooling and some countries have extended this right to cover younger children as well. The OECD study also found that some countries have moreover extended the duration of ECE by lowering the age of compulsory education. They point out that this is often considered an effective option from an equity point of view, as inequalities are likely to exist before schooling starts and tend to grow when school is not compulsory. The European Commission/EACEA/Eurydice/Eurostat (2014) data also indicated that most European countries have committed themselves to providing an ECE place for all children, either by establishing a legal entitlement to ECE or making attendance compulsory for at least the last pre-primary year. However, few European countries guarantee every child an early place in ECE directly following parental leave.

The countries in the ECES reflect a similar developmental journey and were each at a different stage in the development of their ECE system, with some countries having well developed systems with legal entitlements from an early age and others putting in place statutory entitlements in the year or two before primary schooling. Development and change in ECE public policy was underway in most countries.

\section{Policy Issue 1}

ECE is undergoing a period of rapid and significant development and requires continuing policy attention and investment.

The majority of the participating countries in the ECES research have recently undergone, or have planned for the near future, significant structural and systemic changes in their ECE policy, at both ECED and PPE levels. The findings illustrate the dynamic nature of ECE policy, and reflect the growing visibility and importance attached to the development of the ECE as a significant part of the educational and social systems within the study countries. However, the continued complexity of the sector and the diversity of providers and funding mechanisms compared with that found at later stages in the education system make the policy challenges during this phase very different and the change agenda very complex. The changes also indicate that, in many of the study countries, over recent years there has been a significant increase in expenditure on ECE services to support the development of ECE infrastructure, services, and the development of quality. This attention and investment needs to be maintained. 
The Economist Intelligence Unit (EIU, 2012), OECD (2012a), The World Bank (2013), and European Commission/EACEA/Eurydice/Eurostat (2014) all promote ECE as critical to smart and sustainable growth, the development of stable and equitable societies, and to long-term economic prosperity. The ECES confirms that governments across the world are recognizing the value of ECE as a key social, educational, economic and civic lever, and are investing in its development to secure benefits in all these domains.

\section{Policy Issue 2}

Multiple policy aims for ECE are common and reveal the potential value and impact of quality ECE, but they can sometimes compete or conflict with each other.

The ECES research data on stated public policy aims and strategies for ECE reveal that governments in the eight participating countries recognize the value of ECE and are using it as a key tool to help them meet multiple policy agendas. The study countries indicated a wide range of policy aims for ECE, which include aims to support parental employment and training, aims to support a child's development and learning, aims that address wider social and civic issues, and aims which support early intervention for language needs or special needs. This suggests that ECE policy is being used to meet a spectrum of social, economic, educational and political demands in all eight study countries. It does, however, mean that sometimes these different policy aims can compete and conflict with each other.

Public spending on ECE is important as, without sufficient public spending, there is a greater risk that access to ECE programs will be restricted to affluent families and, therefore, that the quality of the programs will vary. Evidence from OECD (2012a) and European Commission/EACEA/Eurydice/Eurostat (2014) shows that there are substantial differences in ECE expenditure among countries. The studies also reveal that publicly-funded ECE tends to be more prevalent in the European than in nonEuropean OECD countries. The extent of private funding also varies widely between countries. In countries where public funding is low, it is likely that some parents may have to or choose to send their children to private ECE services, which can represent heavy financial burdens (OECD, 2012b), and others may prefer to stay home, which can hinder increasing female labor force participation (OECD, 2011).

Affordability is therefore an important factor in ensuring all children have access to ECE, especially for low-income families. Fees for ECE can vary considerable both within and between countries. In some countries all ECE is provided free, in others it is heavily subsidized, and in yet others private funding and parent fees make up the majority of the funding. Local communities often finance ECE for younger children, while they share costs with the central level for older children. The private sector often plays a bigger role in ECE for younger children with more public funding for older children. The most common form of ECE financing found in all these studies is a combination of central and local funding for ECE, with local funding more significant for younger children. The ECES countries reflect this pattern of complex and variable funding for ECE, with some countries providing a free and universal entitlement from a young age and others expecting a significant parental (private) contribution. 


\section{Policy Issue 3}

A complex mix of private/public funding characterizes ECE provision, and this can impact on access for some children and on setting sustainability and viability within the sectors.

Securing adequate funding for a high quality, affordable and accessible ECE system is a challenge for all eight of the ECES countries. In all the study countries, funding for ECE services is complex. There is usually a mix of private, voluntary and publiclyfunded ECE provision, even where universal entitlement is secured and delivered largely through public provision. At ECED level, there is usually much more private, voluntary and community provision, with more publicly-funded provision at PPE level, particularly in the year before entry to primary education. The data also reveals that few providers are fully privately funded, with most private providers also receiving some level of government subsidy in order to support their viability, especially at PPE level. Both demand- and supply-side funding mechanisms are used by governments at ECED and PPE level to support the sustainability of ECE provision. The complexity of funding and the dependence on private funding, and therefore market forces, in some countries and particularly for younger children impacts directly on the sustainability and viability of providers from the private and voluntary sectors. The need for significant public investment in ECE services to sustain provision, secure the quality of services, and enhance participation is clearly demonstrated in the ECES countries.

Evidence from cross-national studies (EIU, 2012; European Commission/EACEA/ Eurydice/Eurostat, 2014; OECD, 2012; Pascal et al., 2012) reveals that in most countries, ECE is split into two separate phases according to age. The split system is the most common form of ECE structure, with provision delivered in separate settings for younger and older children. The age break is usually around three years old. The responsibilities for governance, regulation and funding are divided between different authorities. In contrast, in unitary systems, ECE provision for all children is organized in a single phase and delivered in settings catering for whole age phase. There is no break or transfer between institutions until children start primary schooling. In the ECES countries we found both split and unitary systems, but split systems continue to predominate. 


\section{Policy Issue 4}

There is a persisting structural and organizational split between ECED and PPE, which means that systemic coherence within ECE and between ECE and primary schooling is lacking.

Four of the eight ECES countries have statutory entitlements to some level of ECED (under-threes) service for children, and six have statutory or universal nonmandatory entitlement for children to PPE services (pre-primary) during the final year before transfer to primary education. This reveals that ECE has become an established government responsibility in these countries. However, there continues to be a split in most countries in the organization, regulation, governance and delivery of services in both age phases. For example, a mix of national and subnational governance predominates for both ECED and PPE, but national level governance increases as provision moves towards the pre-primary year and transition to the schooling system. This suggests that, for younger children, there is more room for local or regional variation in the delivery of services.

The split within the ECE phase is also evident in the service delivery in the majority of study countries. Often there are different national and local bodies or ministries responsible for ECED and PPE, and there is a greater variety of types of setting at ECED level, including home-based provision. Pre-primary education settings are more often center-based and more often "school" linked in name, location and purpose. However, in three of the study countries (Estonia, Denmark and Italy) there is development toward a more integrated (unitary) birth to primary school provision.

The continued split in governance, system management, and service delivery between ECED and PPE challenges policymakers in all study countries to ensure effective communication, clarity of roles and responsibilities, and effective partnership working to ensure the governance and management system supports the development of a coherent ECE and care system from birth to primary school entry. Very few of the study countries have secured a full structural and systemic integration of ECE with later phases of education. However, this complexity and distributed system governance model may have strength in encouraging regional and local participation and autonomy within a national framework, and ensuring ECE services have the flexibility to meet diverse local needs. 


\section{Delivery Models and Providers}

The delivery of ECE across the whole age phase is characterized by diversity and complexity, with different providers at different ages and different delivery models. This complexity in service delivery for children from birth to three has been pointed out in several policy studies (EIU, 2012; European Commission/EACEA/Eurydice/Eurostat, 2014; OECD, 2012a) and reveals that the delivery model for ECE is very different to that for primary schooling or secondary schooling in most countries. The ECES countries provided detailed examples of this complexity and the range of delivery models and providers that inject choice and diversity into the system, but also complexity and sometimes inequity.

\section{Policy Issue 5}

A mixed economy of private, public and community sector ECE providers is common, with a diverse variety of setting types delivering ECE services. This provides choice but can lead to inequity in quality and access.

In all the ECES countries there are a variety of setting types delivering ECE services to children under three years old (ECED) and from three years up to primary school age (PPE). These include home-based and center-based services, and may be called crèches, kindergartens, nursery schools, nursery or kindergarten classes in primary schools, kids clubs, preschools, day care centers and integrated centers. In all of the study countries there is also a mix of private, public and community sector providers, particularly serving children under the age of three. This mixed economy often leads to a multiplicity of provider types and service delivery models, with different staffing, curricula and regulatory requirements. This can support choice and diversity of options for parents within and between the sectors, but can also lead to inequity in provision and quality for children.

\section{Participation and Enrollment}

It is well documented that many countries have significantly increased the proportion of children enrolled in ECE programs over recent years (European Commission/EACEA/ Eurydice/Eurostat, 2014; OECD, 2012a). However, as the European Commission/ EACEA/Eurydice/Eurostat (2014) study indicated, in most countries the demand for ECE places is higher than their supply, especially for younger children, and often attendance of children under three years is very low. In contrast, enrollment in the year or two before starting primary education is usually very high. However, disadvantaged children generally have lower ECE participation rates, even if financial support is offered. Increasing the participation of children from disadvantaged backgrounds is a key priority of many governments. Support measures to enhance participation for disadvantaged families exist in most countries and the use of targeting strategies to reach children from low-income households, children with special needs or disability, and migrant children are common. Yet, despite these measures, achieving full enrollment of certain subgroups in the population remains a considerable challenge in many countries, with a few countries making real progress. The ECES countries reflect this mixed success in achieving high levels of enrollment and participation in ECE services. 


\section{Policy Issue 6}

Enrollment in ECE for certain population subgroups remains a challenge, particularly for children from low-income families and children with special needs or disability.

The evidence from the study countries reveals the older the child, the higher the levels of enrollment in ECE, and in the last year before entry to ISCED 1, there is over $86 \%$ enrollment in all of the study countries, with pre-primary education becoming a universal entitlement in most. However, universal access to ECE services is not achieved in the majority of study countries, and this study found a mixed approach to the use of targeting strategies to enhance the participation levels of certain population subgroups. Some countries have adopted a universal and integrated approach to secure enrollment, and others have used targeting as a strategy to increase the engagement of certain subgroups, particularly children from low-income families and children with special needs or disability. Some countries appear to be much more successful in securing the participation of children from low-income families and children with special needs or disability than others. The tension between the policy options of offering funded universal and/or targeted ECE services is visible when considering the study countries and contrasting their success in securing children's participation and enrollment in services, especially for less advantaged children.

\section{Supporting Quality in ECE}

Recent studies (EIU, 2012; OECD, 2012a; World Bank, 2013) reveal that countries across the world are concerned about assuring the quality of ECE and are moving to regulate ECE and put in place stronger systems of accountability, usually through quality accreditation and inspection. It is clear that countries are at different stages in the development of quality assurance procedures. Some countries actively resist too much regulation, whilst others see it as a key priority to safeguard children's well-being and development. The ECES countries reflect these different approaches to quality assurance, and provide exemplification of a range of policy approaches to assuring and delivering quality services.

\section{Policy Issue 7}

Regulation and quality assurance of ECE services to secure, promote and develop quality are used differentially to secure standards which prevent the development of a coherent quality assurance system.

Governments in the ECES all aim to deliver high quality ECE and recognize that greater regulation may be needed to achieve this. All the study countries regulate their ECE services, with regulatory responsibilities being distributed between national and subnational bodies, indicating a desire to ensure all ECE services meet minimal standards. Some countries appear to regulate more than others, and some aspects of service delivery are more regulated than others, with the most regulated aspects overall being health and safety in service delivery, and securing child protection. The data suggests that inspection is used more extensively than 
Policy Issue 7 contd.

accreditation in the study countries to assure quality services at both ECED and PPE levels, although, in the majority of countries, the two processes complement one another; the one being used more for authorization of setting quality and the other for monitoring setting quality. All the countries that have accreditation and inspection processes promote the results to inform the further development of quality in the setting and to ensure key bodies are aware of their quality credentials, as reflected in the reports. There is clear evidence in the study countries of a real attempt to be transparent and accountable to interested bodies and individuals through the use of the reports in development planning, quality improvement, performance management, knowledge creation and transfer, and also to acknowledge and celebrate documented achievements. However, the study suggests that the use of quality reports as a tool to support quality improvement rather than quality assurance could be more effectively used in some countries.

Research has consistently demonstrated that enriched, stimulating environments and high quality pedagogy are fostered by better qualified practitioners, and that better quality pedagogies facilitate better learning outcomes (OECD, 2012a). Qualifications are one of the strongest predictors of staff quality. It is important to note, however, that it is not the qualification level per se; quality is related to how much specialized and practical training is included in initial staff education, what types of professional development and education are available to and taken up by staff, and how many years of experience staff have accumulated. The European Commission/EACEA/Eurydice/ Eurostat (2014) study indicated that three different types of staff typically work as a team in center-based settings in Europe: educational staff, usually qualified to tertiary level (Bachelor's level), care staff with a minimum qualification at upper or postsecondary non-tertiary education; and auxiliary staff/assistants who are not qualified or have a minimum qualification at upper secondary level. Educational staff are usually employed in all settings for older children and are less common in settings for younger children. Some countries require a Master's qualification as minimum qualification to work with older children in ECE. Continuing professional development is less common as an obligation in settings catering for children under three years, whereas it is usually a requirement when working with older children. Recent studies (European Commission/EACEA/Eurydice/Eurostat, 2014; Pascal, \& Bertram, 2012) have also shown that heads or leaders of ECE settings need relevant experience, but that few receive specific leadership or management training, although good leadership is now recognized as important in achieving high quality services.

A number of the ECES countries reflect a greater diversity in the types of practitioners working in ECE settings than other studies have indicated. The analysis also reveals a greater difference and complexity both within and between countries in staff qualifications, training and staff remuneration levels than other studies have indicated. 


\section{Policy Issue 8}

The role, level of professionalism and qualifications of the ECE workforce are characterized by diversity and variability, and there are under qualified and poorly remunerated staff at all levels, particularly at leadership level.

The ECES countries reveal that the staff who work in ECE are characterized by their diversity of qualification, role and status. The study data illustrates the complexity in the staffing of ECE services, which varies by age phase, type of setting, setting provider (public or private), location, and professional role of staff. Many countries do not require graduates (ISCED Level 5 or above) to work at a senior level in ECED or PPE, although the qualification requirement for leaders, and those who work with older children, is usually higher. Continuing professional development is usually an optional requirement for staff and leaders. Specific training in leadership and management is rare. Salary levels vary considerably within the sector, depending on the type of setting, role and type of delivery contract offered. However, relatively low pay rates for some practitioners, particularly those working with younger children, reflect the lack of professional status and qualification level in some parts of the workforce.

Evidence from other studies (EIU, 2012; Eurydice/Eurostat 2014; OECD, 2012a) reveals that many countries set learning objectives related to children's progress and development, and issue official curriculum guidelines to help settings improve their provision. However, the curriculum guidelines are often for older children and not for children under three years. For younger children, the emphasis is often on the care and welfare of children rather than their education and development. Where the curriculum guidelines exist, they tend to include personal, social and emotional development, as well as language and communication skills, physical development and health. Literacy and numeracy often apply only for older children. Most countries also recommend the type of teaching approach, with a balance between adult- and child-led activities, and some underline the importance of free play. In most cases, despite the guidance, settings are free to choose their own curricula and methods.

The ECES countries reflect these policy choices, but several also have curriculum guidelines for younger children. The majority of countries also provide freedom for the practitioners in the settings to choose their own curriculum and pedagogic approach.

\section{Policy Issue 9}

ECE curriculum guidelines are common and reflect a broad range of learning objectives and pedagogic approaches, but need to be extended to the underthrees.

The evidence in the ECES suggests that national curriculum guidance has been developed for early childhood services in the majority of study countries, particularly for the older children (over three years), and that this is broad in scope and usually provides guidance on learning content, pedagogic approaches, learning goals and assessment. The guidance in all countries promotes a broad and balanced range of learning areas to be covered throughout the age phases, with no narrowing of curriculum focus as the child heads towards entry to primary schooling. The 
Policy Issue 9 contd.

non-cognitive areas are well balanced with the cognitive areas at both age phases. Usually, no single pedagogic approach is promoted over others for either younger or older children, but rather a range of pedagogies are encouraged, including more progressive, play-based approaches, and more academic, formal, instructional approaches. This seems to suggest some choice and freedom for settings to develop their preferred approach.

\section{Expectations for Child Outcomes}

Other studies (EIU, 2012; European Commission/EACEA/Eurydice/Eurostat, 2014; OECD, 2012a) have revealed that most countries regularly assess children's progress at setting level and pay special attention to the transition between ECE and primary education. The European Commission/EACEA/Eurydice/Eurostat (2014) report suggests that countries do this mainly through continuous teacher/practitioner observation and not formal testing. In some countries school readiness, maturity and language skills are criteria for entering primary education and are assessed formally at this point. In the ECES countries, the evidence indicated that governments remain reluctant to formalize the assessment process for younger children and only few countries carry out national assessments of children during ECE.

\section{Policy Issue 10}

Expected ECE child outcomes are broad and include executive functioning and child well-being, but national assessments of ECE child outcomes are currently limited in scope and usage.

The ECES countries do not focus on a narrow range of children's learning outcomes, such as literacy and numeracy, in this phase of education, but rather take a broader view of children's learning and the outcomes that early education settings might support. These include cognitive and non-cognitive learning outcomes, such as socio-emotional development, executive functioning and child well-being.

Although ongoing assessment for learning is carried out in settings by practitioners, in the majority of study countries national and formal child assessments are not commonly conducted in this phase, particularly for children under the age of three years, but are more evident in the pre-primary phase. Assessments, when conducted, are used to capture a broad range of learning outcomes, which include cognitive development, executive function and social-emotional well-being, and are not narrowly focused on areas of "school readiness" such as literacy and numeracy. The methods of assessment used to capture children's learning and development in the study countries include practitioner observations, standardized tasks and standardized tests, with a mixture of methods prevalent. Child outcomes data may be reported to a wide group of recipients, each of whom potentially can use the data to inform the development of educative practice for young children in the home, in the setting, in the locality, region, and country as a whole, and in the mindset of the wider public. A range of reporting platforms are used, from ICT, internet websites and other mass dissemination mechanisms, to local, face-to-face interactions, 
Policy Issue 10 contd.

documentation and feedback. The study countries illustrate the potential value of having child outcomes data at a national and subnational level to inform, evaluate and improve system performance, as well as at setting level to inform children's learning plans and setting development. However, there continues to be reluctance in some countries to collect and use child outcomes data for ethical, methodological, and administrative reasons. Policy options in this area need to be sensitively considered and explored, as both parents and practitioners hold strong views on the value of assessment at this young age.

\section{Concluding Comments}

This cross-national policy study reveals that, while some areas of ECE policy and system development appear to be very similar in the study countries, others remain very different and variable, both within and between countries, with government policy often supporting regional and local variation in service delivery, particularly for children under the age of three. The variety of providers, particularly at ECED level, that are identified in many of the study countries may also mean that governments are ensuring the continued existence of more local and culturally nuanced ECE services. For example, the broad based and individually focused curriculum and pedagogic models supported by government policies appears to sustain and reinforce differences in providers, encouraging openness to a variety of educational approaches and practices, and even to a wide range of child outcomes.

It is clear that there is no one way to secure ECE policy development and no one-sizefits-all approach. Countries have a range of different policy options open to them to achieve the overall goal of securing high quality ECE for all children. Depending on each country's context, there are different policy opportunities to be considered. However, the diverse set of policy choices and options in the eight study countries as presented in this report provides an invaluable in-depth account of available systemic policy choices, and the consequences of these choices for service quality, service delivery and children's participation. The report acknowledges that no one country has yet perfected its ECE provision, and further consideration at policy level about how to progress the achievement of high quality ECE for all children is needed in all countries. The set of policy issues identified should provide an agenda for further rich and informed ECE policy dialogues.

Open Access This chapter is distributed under the terms of the Creative Commons AttributionNonCommercial 4.0 International License (http://creativecommons.org/licenses/by-nc/4.0/), which permits any noncommercial use, duplication, adaptation, distribution and reproduction in any medium or format, as long as you give appropriate credit to the original author(s) and the source, provide a link to the Creative Commons license and indicate if changes were made.

The images or other third party material in this chapter are included in the works Creative Commons license, unless indicated otherwise in the credit line; if such material is not included in the works Creative Commons license and the respective action is not permitted by statutory regulation, users will need to obtain permission from the license holder to duplicate, adapt or reproduce the material. 


\section{References}

Aos, S., Lieb, R., Mayfield, J., Miller, M., \& Pennucci, A. (2004). Benefits and Costs of Prevention and Early Intervention Programs for Youth. Document No. 04-073901. Olympia, WA, USA: Washington State Institute for Public Policy.

Barnett, S. (2012). Returns to public investment in ECEC: implementing policies for high quality early childhood education and care (ECEC). Presentation at the OECD/EU Symposium of Education Ministers, Oslo, 24 January 2012. Retrieved 23 May 2013 from http://www.slideshare. net/OECDEDU/returns-to-public-investments-in-ecec-oslo-norway-implementing-policies-forhigh-quality-early-childhood-education-and-care.

Barnett, W.S., Carolan, M.E., Squires, J.H., Clarke Brown, K., \& Horowitz, M. (2015). The state of preschool 2014: State preschool yearbook. New Brunswick, NJ, USA: National Institute for Early Education Research. Retrieved from http://nieer.org/sites/nieer/files/Yearbook2014 full2 0.pdf.

Barnett, W.S., Hustedt, J.T., Allison, H., Friedman, M., Stevenson Boyd, J., \& Ainsworth, P. (2007). The State of Preschool 2007. State preschool yearbook. New Brunswick, NJ, USA: National Institute for Early Education Research.

Bennett, J. (2008). Benchmarks for Early Childhood Services in OECD Countries. Innocenti Working Papers. New York, NY, USA: UNICEF.

Blair, C., \& Diamond, A. (2008). Biological processes in prevention and intervention: The promotion of self-regulation as a means of preventing school failure. Development and Psychopathology, 20, 899-91.

Blair, C., \& Razza R.P. (2007). Relating effortful control, executive function, and false belief understanding to emerging math and literacy ability in kindergarten. Child Development, 78(2), 647-63.

Bradshaw, J., Richardson, D., \& Ritakallio, V-M. (2007). Child poverty and child well-being in Europe. Journal of Children's Services, 2(1), 18-36.

Corak, M., Waldfogel, J., Washbrook, L., Ermisch, J., Vignoles, A., Jerrim, J., Vignoles, A., \& Jerrim, J. (2012) Social mobility and education gaps in the four major Anglophone countries: Research findings for the Social Mobility Summit, Proceedings held at the Royal Society, London, UK, 21-22 May 2012 of research sponsored by Sutton Trust and Carnegie Corporation of New York. London, UK: Sutton Trust. Retrieved from http://www.suttontrust.com/researcharchive/social-mobilityeducation-gaps-four-major-anglophone-countries-research-findings-social-mobility-summitlondon-2012/.

Downey, D.B., von Hippel, P.T., \& Broh, B.A. (2004). Are schools the great equalizer? Cognitive inequality during the summer months and the school year, American Sociological Review, 69(5), 613-635.

EIU. (2012). Starting well: Benchmarking early education across the world. Ed. S. Vadaketh. London, UK: The Economist Intelligence Unit. Retrieved from http://www.economistinsights.com/sites/ default/files/legacy/mgthink/downloads/Starting\%20Well.pdf.

European Commission. (2011). Early childhood education and care: Providing all our children with the best start for the world of tomorrow. Brussels, Belgium: European Commission. Retrieved from http://eur-lex.europa.eu/LexUriServ/LexUriServ.do?uri=COM:2011:0066:FIN:EN:PDF.

European Commission/EACEA/Eurydice/Eurostat. (2014). Key Data on Early Childhood Education and Care in Europe. 2014 Edition. Eurydice and Eurostat Report. Luxembourg: Publications Office of the European Union.

Eurydice. (2009). Early Childhood Education and Care in Europe: Tackling Social and Cultural Inequalities. Brussels, Belgium: EACEA. 
Ginsburg, H.P., \& Amit, M. (2008). What is teaching mathematics to young children? A theoretical perspective and case study. Journal of Applied Developmental Psychology, 29(4), 274-285.

Government of South Australia. (2009). South Australian Curriculum Standards and Accountability Framework. Retrieved 23 May 2013 from http://www.sacsa.sa.edu.au/index_fsrc.asp?t=Home.

Hart, B., \& Risley, I. (1995). Meaningful differences in the everyday experience of young American children. Baltimore, MD, USA: Brookes Publishing.

Heckman, J.J. (2000). The case for investing in disadvantaged young children (CESifo DICE Report). Ifo Institute for Economic Research at the University of Munich, 6(2), 3-8.

Heckman, J.J. (2012). The case for investing in young children, In B. Falk (Ed), Defending Childhood. New York, NY, USA: Teachers College Press.

Howes, C., Phillips, D., \& Whitebrook, M. (1992). Thresholds of quality: Implications for the social development of children in center-based child care. Child Development, 63, 449-460.

Institute of Medicine. (2015) Transforming the workforce for children birth through age 8: A unifying foundation. Report. Washington, DC, USA: Author. Retrieved from http://iom.nationalacademies. org/Reports/2015/Birth-To-Eight.aspx

International Association for the Evaluation of Educational Achievement. (2013). What makes for great early years education? Press release. Retrieved from http://www.iea.nl/fileadmin/user_upload/ Studies/ECES/What_makes_for_great_early_years_education_01.pdf

Istat. (2014). Italy in Figures 2014. Rome, Italy: Italian National Institute of Statistics.

Janta, B. (2009). How childcare, parental leave and flexible working arrangements interact in Europe. Brussels, Belgium: European Commission.

Kaga, Y., Bennett, J., \& Moss, P. (2010). Caring and learning together: A cross-national study on the integration of early childhood care and education within education. Paris, France: UNESCO. Retrieved from http://unesdoc.unesco.org/images/0018/001878/187818E.pdf.

Karoly, L.A., Kilburn, M.R., \& Cannon, J.S. (2005). Early childhood interventions: Proven results, future promise. Santa Monica, CA, USA: Rand.

Li, H., \& Rao, N. (2005). Curricular and instructional influences on early literacy attainment: evidence from Beijing, Hong Kong and Singapore. International Journal of Early Years Education, 13(3), 235-253.

Litjens, I., \& Taguma, M. (2010). Revised literature overview for the 7th Meeting of the Network on Early Childhood Education and Care. Paris, France: OECD. Retrieved from http://www.oecd. org/officialdocuments/publicdisplaydocumentpdf/?cote=EDU/EDPC/ECEC\%282010\%293/ REV1\&doclanguage $=$ en

Lynch R. (2007). Early childhood investment yields big payoff. San Francisco, CA, USA: WestEd.

McKinsey (2007)

Montie, J.E., Xiang, Z., \& Schweinhart, L.J. (2006). Preschool experience in 10 countries: Cognitive and language performance at age 7. Early Childhood Research Quarterly, 21, 313-331.

Muijs, D., Aubrey, C., Harris A., \& Briggs, M. (2004). How do they manage? A review of the research on leadership in early childhood. Journal of Early Childhood Education Research, 2, 157-169.

Mullis, I.V.S., Martin, M.O., Foy, P., \& Drucker, K.T. (2012). PIRLS 2011 international results in reading. Chestnut Hill, MA, USA: Boston College, TIMSS and PIRLS International Study Center.

Nagaoka, N., Farrington, C. A., Ehrlich, S. B., \& Heath, R. D. (2015). Foundations for young adult success: A developmental framework. Chicago, IL, USA: The University of Chicago Consortium on Chicago School Research.

Ministry of Social Development, (2011). National Socioeconomic Survey (CASEN) of Chile. Chile: Ministry of Social Development. 
NSECE. (2012). National Survey of Early Care and Education, OPRE (Office of Planning Research and Evaluation) Report. Washington, DC, USA: US Department of Health and Human Services, Administration for Children and Families.

Oberhuemer, P. (2005). Conceptualising the Early Pedagogue: Policy Approaches and Issue of Professionalism, European Early Childhood Education Research Journal, 13(1), 5-16.

OECD. (2001). Starting Strong I: Early Childhood Education and Care. Paris, France: Author.

OECD. (2006). Starting Strong II: Early Childhood Education and Care. Paris, France: Author. Retrieved from http://www.oecd.org/edu/school/startingstrongiiearlychildhoodeducationandcare. htm.

OECD. (2010). Education at a Glance 2010: OECD Indicators. Paris, France: Author.

OECD. (2011). Doing Better for Families, Paris, France: Author.

OECD. (2012a). Education at a Glance 2012: OECD Indicators. Paris, France: Author. Retrieved from http://dx.doi.org/10.1787/eag-2012-en.

OECD. (2012b). Starting Strong III: A Quality Toolbox for Early Childhood Education and Care. Paris, France: Author. Retrieved from http://www.oecd.org/edu/school/ startingstrongiiiaqualitytoolboxforearlychildhoodeducationandcare.htm.

OECD. (2013). How Do Early Childhood Education and Care (ECEC) Policies, Systems and Quality Vary Across OECD Countries? Education Indicators in Focus, No. 11. Paris, France: Author. Retrieved from http://www.oecd.org/education/skills-beyond-school/EDIF11.pdf.

Pascal, C., \& Bertram, T. (2008). Accounting Early for Lifelong Learning. Amber Publications: Exchange Birmingham, UK and Amber Publications.

Pascal, C., \& Bertram T. (2012). The Impact of Early Education as a Strategy in Countering Socioeconomic Disadvantage. London, UK: Ofsted.

Pascal, C., Bertram, T., Delaney, S., \& Nelson, C. (2012). A Comparison of International Childcare Systems: Evidence to Childcare Commission. London, UK: Department for Education.

Pepper, D., \& May, T. (2009). Thematic Probe: Early Years International Themes (INCA Thematic Probe). Slough, UK: NFER.

Pramling Samuelsson, I., Sheridan, S., \& Williams, P. (2006). Five preschool curricula: A comparative perspective. International Journal of Early Childhood, 38 (1) 11-30.

Reid, J. L., \& Kagan S.L. (2015). A Better Start: Why Classroom Diversity Matters in Early Education. Washington DC, USA: The Century Foundation and The Poverty and Race Research Action Council.

Reid, J. L., \& Ready D. D. (2013). High-quality Preschool: The Socio-economic Composition of Preschool Classrooms and Children's Learning. Early Education and Development 24 (8) 108-111.

Rodd, J. (2005). Leadership in Early Childhood: The Pathway to Professionalism. Milton Keynes, UK: Open University Press.

SASS (2012) The US Department of Education, National Center for Education Statistics, Schools and Staffing Survey, 2011-2012 SASS tables (Retrieved from https://nces.ed.gov/surveys/sass/ tables_list.asp.

Smolíková, K., Opravilová, E., Havlínová, M., Bláhová, A., \& Krejčová, V. (2004). Framework education programme for preschool education. Prague, The Czech Republic: Research Institute of Education.

Stephen, C. (2006). Early years education: Perspectives from a Review of the international literature. Edinburgh, UK: Scottish Executive. Retrieved from https://dspace.stir.ac.uk/ bitstream/1893/3209/1/full\%20review.pdf. 
Strickland, D., \& Riley-Ayers, S. (2006). Early literacy: Policy and practice in the preschool years (Policy Brief Issue 10). New Brunswick, NJ, USA: NIEER. Retrieved from http://nieer.org/ resources/policybriefs/10.pdf.

Sylva, K., Melhuish, E., Sammons, P., Siraj-Blatchford I., \& Taggart, B. (2004). The Effective Provision of Pre School Education (EPPE) Project: Findings from pre-school to the end of key stage 1. London, UK: DfES.

Sylva, K., Melhuish, E., Sammons, P., Siraj-Blatchford I., \& Taggart, B., with Hunt, S., Jelicic, H., Barreau, S., Grabbe, Y., Smees, R., \& Welcomme, W. (2008). Effective Pre-school and Primary Education 3-11 Project (EPPE 3-11): Final report from the primary phase: pre-school, school and family influences on children's development during key stage 2 (age 7-11). DfE Research Brief 061. London, UK: DfE.

UNESCO Institute for Statistics. (2012). ISCED: International Standard Classification of Education. Paris, France: UNESCO. Retrieved from http://www.uis.unesco.org/Education/Pages/ international-standard-classification-of-education.aspx.

UNESCO Institute for Statistics. (2014). Country profiles. Russian Federation, 2013. Paris, France: UNESCO. Retrieved from http://www.uis.unesco.org/DataCentre/Pages/country-profile. aspx? code $=$ RUS\&region $\operatorname{code}=40530$

US Department of Labor. (1993). The Family and Medical Leave Act. Washington, DC, USA: Author. Retrieved from http://www.dol.gov/whd/fmla/

US Department of Education. (2012a). Early Childhood Program Participation Survey of the National Household Education Surveys Program (ECPP-NHES: 2012). Washington, DC, USA: US Department of Education, National Center for Education Statistics.

US Department of Education. (2012b). Parent and Family Involvement in Education (PFI) of the National Household Education Surveys Program (PFI-NHES 2012). Washington, DC, USA: US Department of Education, National Center for Education Statistics.

Van Laere, K., Peeters, J., \& Vandenbroeck, M. (2012). The education and care divide: the role of the early childhood workforce in 15 European countries. European Journal of Education, 47(4), $527-541$

Waldfogel, J. (2012). Gaps in the preschool years, school readiness, and early school achievement: policy responses. Paper presented at the Sutton Trust/Carnegie Corporation Summit on Social Mobility, The Royal Society, London, 21-22 May 2012. Retrieved 23 May 2013 from http://www. suttontrust.com/research/social-mobility-summit-jane-waldfogel-presentation/.

Waldfogel, J., \& Washbrook, E. (2008). Early years policy. In Social Mobility and Education. Academic papers presented at a high level summit sponsored by the Carnegie Corporation of New York and the Sutton Trust, 1-3 June 2008 (pp. 49-86). London, UK: The Sutton Trust. Retrieved from http://www.suttontrust.com/wp-content/uploads/2009/09/academic_papers_report.pdf.

World Bank. (2013). What matters most for early childhood development: A framework paper. Working Paper Series No 5, January 2013. Washington DC, USA: World Bank.

Open Access This chapter is distributed under the terms of the Creative Commons AttributionNonCommercial 4.0 International License (http://creativecommons.org/licenses/by-nc/4.0/), which permits any noncommercial use, duplication, adaptation, distribution and reproduction in any medium or format, as long as you give appropriate credit to the original author(s) and the source, provide a link to the Creative Commons license and indicate if changes were made.

The images or other third party material in this chapter are included in the works Creative Commons license, unless indicated otherwise in the credit line; if such material is not included in the works Creative Commons license and the respective action is not permitted by statutory regulation, users will need to obtain permission from the license holder to duplicate, adapt or reproduce the material. 


\section{APPENDIX A: \\ Glossary}

\section{Accreditation:}

Accreditation of ECE settings is the process of gaining official approval from an independent external body usually involving a site visit and inspection to assess whether the setting owners have met minimum requirements for operation. Accreditation can be given before opening or shortly after opening and sometimes has to be regularly renewed.

\section{Assessment:}

Refers to the wide variety of methods that educators use to evaluate, measure, and document the academic readiness, learning progress, and skill acquisition of children, in this case, at ISCED 0.

\section{Capital grants:}

A start-up grant is usually given by a governmental body to a provider to allow them to acquire or improve capital goods like land or buildings.

\section{Catchment area:}

This is the geographical reach area of the setting, that is, the extent of the settings' range from which it draws its children. In some countries, in order to avoid geographical gaps in provision or over subscription in others, this is carefully regulated.

\section{Central funds:}

Central funds are funds that come from a central organizing body usually the government.

\section{Child protection:}

Child protection is the process of protecting individual children identified as either suffering, or likely to suffer, significant harm as a result of abuse or neglect. It involves measures and structures designed to prevent and respond to abuse and neglect.

\section{Children's well-being:}

Bradshaw et al. (2007) offer this definition of well-being: “...well-being can be defined as the realization of children's rights and the fulfilment of the opportunity for every child to be all she or he can be in the light of a child's abilities, potential and skills. The degree to which this is achieved can be measured in terms of positive child outcomes, whereas negative outcomes and deprivation point to the neglect of children's rights."

\section{Commissioning:}

Commissioning is a process of ensuring that the programs and services are provided effectively to meet the needs of the population. Public bodies or private for-profit or nonprofit organizations or charities can apply, usually competitively, to the "commissioning agent" (often a national or regional government department) for funds to provide a program or service. It is a systemic process of bringing the operation of market forces into public services.

\section{Compliance monitoring body:}

A compliance monitoring body is an organization (often part of the quality control and accountability structure) that ensures that ECE settings comply with regulatory requirements either nationally or locally.

\section{Crèche:}

A crèche is a nursery where babies and young children are cared for and educated during the working day.

\section{Cultural diversity:}

Cultural diversity refers to the cultural variety and cultural differences that exist in the world, a society, an organization or an institution. Groups or organizations which embrace cultural diversity are said to be inclusive. Cultures which are diverse are not monocultural. Diversity provides richness and variety, and also has the potential to create particular issues or tensions within the educational system, arising from such matters as different value bases, beliefs or attitudes, different languages or diets or behaviors. 


\section{Daily length of provision:}

The usual hours that a setting is open each day. Not all children will take up all this availability, but the opportunity to do so is there for them and their parents.

\section{Demand-side funding:}

Demand-side funding refers to a situation in which government makes external funds available directly to parents so parents can choose where to place their children. It enables parents to be consumers and to make choices. Such funding may take the form of parent grants or reduced fees, parent vouchers or credit authorization for ECE child care, tax relief or reduction, or general child or family allowances where parents receive weekly or monthly funds from the state to support their child's upbringing.

\section{ECE providers:}

A provider is someone who provides or makes provision for a service. This can be at a micro level, where one owner is providing a setting. More usually the word is used to describe a body or organization providing more than one setting. Typically the greatest provider in social welfare oriented countries is the government (local or national), whose settings are maintained by central funds and usually free to parents and provision is universal (accessible to everyone). Other providers may be religious bodies and other nongovernment bodies, such as charities. Many providers are private businesses, either run for profit or nonprofit making. Some industries, factories and unions may also provide ECE settings for their staff or members.

\section{ECE setting:}

ECE setting is a general term for a range of different types of ECE organizations that offer ECE to children (such as a nursery, kindergarten or school).

\section{Enrollment rates:}

This refers to the numbers of children at various ages enrolled in settings as a percentage of the total population.

\section{Family allowances:}

This is a regular government payment to the parents of children up to a certain age. It is sometimes called child benefit. In some countries this is used as a mechanism to influence demographics.

\section{Freinet:}

The French educator, Freinet, began the Modern School Movement which is practiced in many countries. The approach includes: 1 . a pedagogy of work (pédagogie du travail) where pupils are encouraged to learn by making products or providing services. 2. Enquiry-based learning (tâtonnement expérimental) which involves group-based trial and error work. 3. Cooperative learning (travail coopératif) where pupils are required to co-operate in the production process. 4 . Centers of interest (complexe d'intérêt in which the children's interests and natural curiosity are starting points for a learning process. 5. The natural method (méthode naturelle) which is seen as authentic learning by using real experiences of children and learning about democracy.

\section{Funded places subsidy:}

This is a demand-side funding mechanism where providers receive full or part funding for places in their settings on condition they reserve those places for particular categories of children, usually those who are considered to be in need, either as free places with no cost to the parent or at a reduced fee.

\section{Gross domestic product (GDP):}

The monetary value of all the finished goods and services produced within a country's borders in a specific time period (usually calculated on an annual basis). It includes all of private and public consumption, government outlays, investments and exports after the value of imports has been deducted. Where possible, GDP data in this study should refer to the period 2013-2014. Where national data are not readily available, the reader should consult World Bank or UNESCO data.

\section{Guidance:}

Guidance is the act or function of giving direction, advice or counselling to support and improve setting or staff activities. Sometimes guidance is legally enforced and thus becomes a requirement or regulation (see below). 


\section{Guidelines:}

Generally guidelines are recommendations, suggestions or prompts seeking to promote good practice, but are not usually statutory obligations or legally enforced.

High income:

High income families are defined as families that are supported by or earn income considered high in comparison with that of the larger population. In this study, families in the top $20 \%$ of income earners in the country are considered "high income."

\section{HighScope:}

Weikart and others designed an approach to learning in the early years based on what is now referred to as "executive functioning." It included approaches to learning, such as, Initiative: children demonstrate initiative as they explore their world, Planning: children make plans and follow through on their intentions, Engagement: children focus on activities that interest them, Problem solving: children solve problems encountered in play, Use of resources: children gather information and formulate ideas about their world, and Reflection: children reflecting on their experiences.

\section{Illness protocols:}

Many settings will have prescribed protocols for children who become ill or arrive at the setting ill. These may include isolation whilst infected, parent notification or exclusion protocols. These protocols may be determined by policy making bodies or authorities.

\section{Inspection:}

Inspection is the act of looking at something closely in order to learn more about it, to find problems, to scrutinize or assess it. Sometimes the processes are standardized nationally or subnationally to enable comparisons between one setting and another. Most countries have an inspection service that includes an official visit to a setting.

\section{ISCED 0:}

Defined by the UNESCO (2012) as:

"the initial stage of organized instruction, designed primarily to introduce very young children to a school-type environment, that is, to provide a bridge between home and a school-based atmosphere. ISCED level 0 programs should be center or school-based, be designed to meet the educational and developmental needs of children at least three years of age, and have staff that are adequately trained (i.e., qualified) to provide an educational program for the children."

See also the attached Appendix 1 from the UNESCO Institute for Statistics for a fuller description or the complete PDF at: http://www.uis.unesco.org/Education/Documents/isced-2011-en.pdf

ISCED 1 covers Primary education: a fuller description can be found in pp30-32 in: http://www. uis.unesco.org/Education/Documents/isced-2011-en.pdf.

ISCED 2 covers Lower Secondary education: a fuller description can be found in pp. 33-37 in: http://www.uis.unesco.org/Education/Documents/isced-2011-en.pdf.

ISCED 3 covers Upper Secondary education: a fuller description can be found in pp. 38-42 in: http://www.uis.unesco.org/Education/Documents/isced-2011-en.pdf.

ISCED 4 covers Post-secondary non-tertiary education: a fuller description can be found in pp. 43-45 in: http://www.uis.unesco.org/Education/Documents/isced-2011-en.pdf.

ISCED 5 covers Short-cycle tertiary education: a fuller description can be found in pp. 48-50 in: http://www.uis.unesco.org/Education/Documents/isced-2011-en.pdf.

ISCED 6 is a Bachelor's or equivalent level degree: a fuller description can be found in pp. 51-54 in: http://www.uis.unesco.org/Education/Documents/isced-2011-en.pdf.

ISCED 7 is Master's or equivalent level: a fuller description can be found in pp. 55-58 in: http:// www.uis.unesco.org/Education/Documents/isced-2011-en.pdf.

ISCED 8 is Doctoral or equivalent level: a fuller description can be found in pp. 59-61 in: http:// www.uis.unesco.org/Education/Documents/isced-2011-en.pdf.

\section{Kindergarten:}

A kindergarten is an establishment where children below the age of compulsory education play and learn. It is also used to refer to a class or school that prepares children, usually five- or six-yearolds, for the first year of formal education. 


\section{Learning contexts and/or environments:}

Learning contexts or environments are the spaces or situations that are constructed by settings or their staff to ensure that children's learning takes place within them or is intensified or maximized.

\section{Low income:}

Low-income families are defined as families that are supported by or earn income considered low in comparison with that of the larger population. In this study, families with less than $20 \%$ of income earners in the country are considered "low income."

\section{Medicine protocols:}

When children who need continual medication are allowed to attend and bring these medicines to settings, it would be usual for protocols to be in place to regulate who and how they are administered, what permissions are needed, and how potential consequences are recognized.

\section{Minority ethnic:}

Minority ethnic is defined as a group within a community which has different language or cultural traditions from the majority of the population. In some countries there may be several minority ethnic groups.

\section{Montessori:}

Montessori is an educational approach developed by Italian physician and educator Maria Montessori and characterized by an emphasis on autonomy within a social environment of freedom within limits, and respect for a child's natural psychological, physical, and social development. In early years settings they are usually mixed age classes with a constructivist approach, based upon a carefully prepared and rich environment with self-correcting developmental materials, where the child is free to choose the activities. Children best develop following their interests through a self-guided curriculum. The role of a Montessori teacher is to observe and guide, rather than to provide directive teaching.

\section{Nursery school:}

A school for young children, mainly between the ages of three and five.

\section{Parents or primary care-givers:}

A parent is defined as the child's mother, father, adopter, guardian, special guardian or foster parent; or someone who is married to, or the partner/civil partner of the child's mother, father, adopter, guardian, special guardian or foster parent, that is a person who acts as a parent and guardian for a child in place of the child's natural parents but without legally adopting the child. A primary care-giver will be someone who does not fit the definition of a parent but has unpaid, primary responsibility for the child, for example, a grandparent or an aunt.

\section{Pedagogic approaches:}

Pedagogic approaches to teaching and learning undertaken by the practitioners in a setting, which reflect the philosophies, values, theories or concepts adopted in the setting and inform the teaching and learning.

\section{Project approach:}

This is an open-ended, in-depth approach encouraging children to develop their strong disposition to explore and discover. The project approach builds on natural curiosity, enabling children to interact, question, connect, problem-solve, communicate, reflect, and more. This kind of authentic learning extends beyond the classroom to each student's home, community, nation, and the world. It essentially makes learning the stuff of real life and children active participants in and shapers of their worlds.

\section{Providers:}

An ECE provider is an individual or organization that supplies services or settings for the education and care of young children. ECE providers can be very varied: for example, they may include a single individual, such as a home-based carer or child minder; a nationwide central government education department funding and maintaining all ECE settings; a local government funding a regional area; "for profit" or "not for profit" organizations; or other nongovernmental organizations, charities, religious groups or foundations. 
Publicly subsidized and private expenditure or funding:

Public funding comes out of the public purse through government and is not paid by parents or charities or private organizations. In ECE, many settings will be funded centrally from local or national governments (public funding) either through supply-side or demand-side grants. Some settings may be funded independently of government through parental contributions, charities, business or employee organizations or other nongovernmental organizations. If these bodies and individuals are not receiving public funds, then their expenditure for ECE services is termed "private."

\section{Quality assurance:}

Quality assurance is the regular and continuous process by which those who work in or administer ECE ensure that children receive a quality experience. This may include review, evaluation and reflection, monitoring and measurement, assessment, professional development, and curriculum improvement. It can be undertaken internally or externally by independent assessors or inspectors.

Reggio Emilia:

The Reggio Emilia Approach is an educational philosophy focused on preschool and primary education, developed by the Italian socialist Loris Malaguzzi. The assumption is that people form their own personality during the early years of development and, moreover, that children are endowed with "a hundred languages." The aim of this approach is teaching how to make them useful in everyday life. The program is based on the principles of respect, responsibility, and community through exploration and discovery in a supportive and enriching environment based on the interests of the children through a self-guided curriculum.

\section{Regulations:}

A regulation is a rule or law designed to control or govern conduct. Governments and other executive agencies generally produce written instruments containing rules having the force of law.

\section{Reduced fees:}

Fee reduction is a mechanism to make ECE more cost attractive to certain groups or families. Sometimes providers, for example, will do this for charitable reasons or to attract particular types of pupils. More usually a subsidy may be paid by a government body to a provider to encourage them to take on particular types of pupils, or directly to parents to encourage them to take up ECE.

\section{Resource grants:}

As part of a supply-side funding strategy, some countries or organizations support providers by providing grants for resources, for example, computers, sports facilities or books.

\section{Responsibility:}

Responsibility in this context seeks to determine where, or by whom, ECE legislation and the legal and policy framework is set. Who has the overarching authority to make these decisions?

\section{Risk assessments:}

A risk assessment is a careful examination of what could cause harm to children or other people, so that formal consideration is given as to whether enough precautions have been taken or more should be done to prevent, reduce or mitigate harm.

\section{Special needs:}

Special needs refer to a child's needs or disabilities that affect their ability to learn. For example:

- behavioral/social (e.g. difficulty making friends)

- reading and writing (e.g. dyslexia)

- understanding things (poor cognitive functioning)

- concentrating (e.g. attention deficit hyperactivity disorder)

- physical needs or impairments.

Staff salary subsidy:

As part of a supply-side funding strategy, some countries or organizations support providers by making grants available to cover staffing costs to lower the cost of ECE for parents whilst improving the quality of staff. 


\section{Standardized tasks and tests:}

A "test" is a set of questions or responses designed to assess the level of performance of a child in a defined area of learning. A "task" is an activity in which a child takes part and which is designed to provide the child with an opportunity to display their competence or ability in a certain area of learning. "Standardized" means that the content and format of the test or task and the conditions under which it is administered and scored are controlled to make it the same for all test and task takers. Children will take the same test or task, in the same conditions, at the same time, if possible, so results can be attributed to the child's performance and not to differences in the administration of the form of the task or test or any other bias.

\section{Statutory entitlement:}

Countries may have laws, regulations or decrees about the statutory rights of parents to free or subsidized ECE provision and for how many hours a day. In addition many countries will have statutory or legal entitlements to parental leave, or to such things as payments to parents for child support. Not all parents will avail themselves of their statutory entitlements.

\section{Steiner:}

Waldorf (Steiner) education is a humanistic approach to pedagogy based on the educational philosophy of the Austrian philosopher Rudolf Steiner. Waldorf pedagogy in early years' education focuses on providing practical, hands-on activities and environments that encourage creative play. The approach stresses the role of the imagination in learning and places a strong value on integrating intellectual, practical, and artistic themes. The educational philosophy's overarching goal is to develop free, morally responsible, and integrated individuals equipped with a high degree of social competence.

\section{Strategies:}

Strategies are systems, pathways or route maps, for finding, formulating and developing a doctrine or a series of actions, which by using higher level strategic planning or thinking is intended to ensure long-term success if followed.

\section{Step by Step:}

Step by Step is an education reform program that introduces child-centered teaching methods and supports community and family involvement in preschools and primary schools. The aim of the program is to engender democratic ideas and principles within young children and their families. The Step by Step methods encourage children to make choices, take responsibility for their decisions, express their ideas with creativity, help each other, develop critical thinking skills, and practice independent thinking. Parents actively participate in the education of their children. The program promotes the rights of all children to a quality education, and provides materials and training to insure equal access for children of minority families, children with disabilities, Roma, refugee and families living in poverty. The program is funded by George Soros' Open Society and operates particularly in Eastern Europe, Africa and the former Soviet areas of Asia.

\section{Supply-side funding:}

This is when, in order to make services cheaper, or of better quality or more accessible to parents, external funds are made available by the state or other public body to a supplier or provider of ECE to increase or improve their provision. Supply-side funds, for example, may take the form of direct grants for building (capital grants), resources (resource grants), grants to supplement staff wages (staff salary subsidy) or increase quality through their training. Sometimes government bodies will fund private providers by paying a subsidy based on places provided. Such grants are termed, "funded places subsidies."

\section{Tax credits/relief:}

Is a mechanism by which governments reduce the amount that can be deducted from a person's taxable annual income to reduce the amount on which tax is paid. For example, in some countries tax credits are made available to working parents with young children to help with the costs of ECE. Some countries use this mechanism to target specific types of families, for example, low salaried, unemployed or single parents. 


\section{Te Whāriki:}

Te Whāriki is New Zealand's Ministry of Education's early childhood curriculum policy statement. Te Whāriki is a framework for providing children's early learning and development within a sociocultural context. It emphasizes the learning partnership between teachers, parents, and families. Teachers weave a holistic curriculum in response to children's learning and development in the early childhood setting and the wider context of the child's world. Te Whariki has had a worldwide influence on pedagogic approaches.

\section{Transition:}

In ECE, this describes the process and procedures of transferring children from one setting to another. Sometimes there are policies in place, such as record sharing or pre-transition visits, to ease the process for parents and children or settings to ensure there is some connection or continuity of experience.

\section{Universal or targeted:}

Universal services are available to everyone, whereas targeted services are intended to be available to specified individuals, groups, communities or regions.

\section{Universal coverage:}

Universal coverage of ECE programs and provision occurs where early years' settings and programs are accessible and available to all children, even though parents may not always take up that availability.

\section{Voluntary:}

In early years, the "voluntary sector" describes those organizations who may have a philanthropic, vocational approach, that is, they may rely on volunteers and usually do not work for profit. For example, many churches and charities provide child care and education support for parents. Voluntary providers may get direct help from the state but are usually not described as being in the state-maintained sector or "private for profit" sector.

\section{Vouchers:}

A voucher is usually a printed ticket (or electronic version of a ticket) that can be exchanged for goods. Some governments and firms give parents vouchers to help with their child care needs. Vouchers can be used to create a market based on parent choice. They can also be targeted at certain groups who are seen as requiring particular support.

\section{Vulnerable children:}

Children with a disadvantaged background often face barriers to educational achievement. Poverty and underachievement at school are the two most predictive factors in a child's future success. Deprivation is commonly associated with other factors which can influence children's outcomes: ill health; family stress; low levels of parental education and parental involvement in their children's education; low levels of cultural and social capital; and low aspirations. This complex interaction of social and demographic factors, low expectation, poor attainment and underperformance, and the subsequent cost of this alienation and social exclusion has led many governments to target these children defined as "vulnerable" or, sometimes, "most in need."

\section{Work/life balance:}

Work/life balance refers to the balancing of the time given to an individual's personal life with that given to work to maintain health and productivity.

Open Access This chapter is distributed under the terms of the Creative Commons AttributionNonCommercial 4.0 International License (http://creativecommons.org/licenses/by-nc/4.0/), which permits any noncommercial use, duplication, adaptation, distribution and reproduction in any medium or format, as long as you give appropriate credit to the original author(s) and the source, provide a link to the Creative Commons license and indicate if changes were made.

The images or other third party material in this chapter are included in the works Creative Commons license, unless indicated otherwise in the credit line; if such material is not included in the works Creative Commons license and the respective action is not permitted by statutory regulation, users will need to obtain permission from the license holder to duplicate, adapt or reproduce the material. 



\section{APPENDIX B: \\ Organizations and Individuals Involved in ECES}

The study was designed as a collaborative effort involving many individuals around the world. This appendix acknowledges the individuals and organizations for their contributions. Given that work on ECES has spanned approximately four years and has involved so many people and organizations, this list may not include all who contributed. Any omission is inadvertent.

\section{Study Management and Coordination}

The study has been managed by a central consortium of three partner organizations, steered by a Joint Management Committee (JMC) led by the IEA, and a Project Advisory Committee (PAC), and implemented in participating countries by NRC led national study centers.

The consortium comprised three organizations, working closely together as equal partners, which will maintain an overview and provide a steer throughout the project. The partner organizations are: the IEA Data Processing and Research Center, the National Foundation for Educational Research (NFER), and the Centre for Research in Early Childhood (CREC). Together these organizations have an excellent track record in conducting and interpreting international comparative studies and surveys in education and in researching early childhood education.

The IEA DPC is part of the International Association for the Evaluation of Educational Achievement (IEA), a non-profit foundation with headquarters in Amsterdam. Since 1995, the IEA DPC has been responsible for all data processing related tasks for all

DPC

http://www.iea-dpc.de

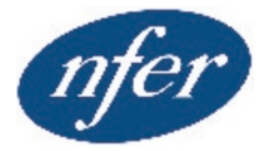

http://www.nfer.ac.uk IEA studies including maintaining a close collaboration with participating countries to monitor their implementation of the survey operation procedures and to assist them in case of problems. Staffed by a team of more than 140 experienced and dedicated individuals, the IEA DPC is well equipped to conduct the variety of data management, data analysis, and sampling tasks associated with international large scale assessments. This includes all cycles of the TIMSS and PIRLS assessments, but also studies such as IEA CIVIC and ICCS, IEA TEDS-M, and the quantitative modules I and III of the IEA SITES. For more recent studies, the responsibility of the IEA DPC has widened, including additional tasks such as weighting and scaling of data and developing analysis software. The IEA DPC is the International Study Center for the OECD TALIS study and the International Coordination Center for the IEA ICCS 2016 study.

NFER is the UK's largest independent provider of research, assessment and information services for education, training and children's services. It aims, through its work, to make a difference to learners of all ages, especially to the lives of children and young people, by supporting improvement in the practice and understanding of those who work with and for learners. NFER is and/or has been the National Research Centre for many large-scale international comparison surveys, including TIMSS (1995 onwards), PIRLS (2001 onwards), CivEd (1999) and ICCS (2009), and PISA (2006 onwards). NFER staff members also have experience at consortium level within some of these surveys. NFER has also conducted numerous research projects in the field of ECE. 
Centre for

Research in - Early

Childhood

http://www.crec.co.uk/

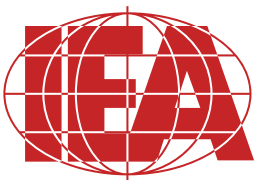

http://www.iea.nl
CREC is a UK-based, independent early years' research and training center, which aims to work collaboratively to pursue research, evaluation, scholarship, professional development, and research-related consultancy within the field of early childhood in order to raise the quality, status and visibility of this crucial area of national policy and practice. Led by Professor Dr Christine Pascal and Professor Dr Tony Bertram, who also serve as President and Coordinating Editor, respectively, for the European Early Childhood Education Research Association (EECERA), CREC has worked extensively on ECE curriculum and assessment at policy and practice levels, both within the UK and internationally. Although an independent research organization, CREC is formally affiliated with three UK Universities and in the most recent academic year has seen over 150 of its students gain doctoral or postgraduate qualifications. CREC has conducted several large scale cross-national research studies and has recently completed an international ECE policy focused comparative benchmarking exercise on behalf of The Economist Intelligence Unit (EIU, 2012). The CREC Secretariat hosts the European Early Childhood Education Research Journal, one of only three citation listed EC journals in the world, holds an international ECE database, and hosts a network of ECE researchers with whom they have an agreement to cooperate on accessing international data and evidence.

The IEA Secretariat is headquartered in Amsterdam, the Netherlands. The Secretariat manages the translation verification and quality control monitoring programs for all IEA studies, as well as the publication and dissemination processes. The IEA Secretariat also provides management and coordination, financial services and administration for the Association, and is responsible for organizing the IEA annual General Assembly and the IEA's biennial International Research Conference (IRC).

\section{IEA Data Processing and Research Center}

Juliane Hencke, ECES Study Director

Steffen Knoll, ECES Deputy Study Director

Marta Kostek, ECES Study Coordinator

Agnes Stancel-Piatak, Researcher (Research and Analysis)

Sabine Meinck, Researcher (Sampling)

Hannah Köhler, Data Analyst

\section{CREC}

Tony Bertram, Associate Research Director (Policy Questionnaire and Policy Report)

Chris Pascal, Associate Research Director (Policy Questionnaire and Policy Report)

Anne Cummins, Analysis Team

Sean Delaney, Analysis Team

Chris Ludlow, Analysis Team

Helen Lyndon, Analysis Team

\section{NFER}

Caroline Sharp, Associate Research Director

Bethan Burge, Researcher 


\section{IEA Secretariat}

Paulína Koršňáková, Director of the IEA Secretariat

Roel Burgers, Financial Manager

Gillian Wilson, Publications Officer

\section{Project Advisory Committee}

Sylvia Eyzaguirre

Ministry of Education, Chile

Jin Sun

The Hong Kong Institute of Education, Department of Early Childhood, Hong Kong

Cristina Stringer

Istituto Nazionale per la Valutazione del Sistema Educativo di Istruzione e di Formazione (INVALSI), Italy

Elena Yudina

Moscow High School of Social \& Economic Sciences, University of Psychology and Education, Russian Federation

\section{Country Representatives}

Chile

Gabriela Cares Osorio

Agencia de Calidad de la Educación

\section{Czech Republic}

Irena Borkovcova

Josef Basl

Czech School Inspectorate

\section{Denmark}

Charlotte Ringsmose

Grethe Kragh-Müller

University of Aarhus, Department of Education

Estonia

Marika Veisson

Tiina Peterson

Tallinn University

Italy

Cristina Stringher

Instituto Nazionale per la Valutazione del Sistema Educativo di Istruzione e di Formazione

\section{Poland}

Kamil Sijko

Piotr Rycielski

Educational Research Institute 


\section{Russian Federation}

Elena Yudina

Moscow High School of Social \& Economic Sciences, University of Psychology and

Education

\section{United States}

Dana Kelly

National Center for Education Statistics, US Department of Education

Kristin Flanagan

American Institutes for Research

Open Access This chapter is distributed under the terms of the Creative Commons AttributionNonCommercial 4.0 International License (http://creativecommons.org/licenses/by-nc/4.0/), which permits any noncommercial use, duplication, adaptation, distribution and reproduction in any medium or format, as long as you give appropriate credit to the original author(s) and the source, provide a link to the Creative Commons license and indicate if changes were made.

The images or other third party material in this chapter are included in the works Creative Commons license, unless indicated otherwise in the credit line; if such material is not included in the works Creative Commons license and the respective action is not permitted by statutory regulation, users will need to obtain permission from the license holder to duplicate, adapt or reproduce the material. 